\title{
Double Deterrence and International Mediation
}

\author{
Dissertation \\ zur Erlangung des Doktorgrades \\ der Sozialwissenschaftlichen Fakultät \\ der Georg-August-Universität
}

vorgelegt von

ANIL KOCAMAN

geboren in Ankara, Türkei

Göttingen, 2018 
Erstbetreuer: $\quad$ Prof. h.c. Dr. Peter W. Schulze

Weitere Betreuer: Prof. Dr. Walter Reese-Schäfer

Prof. Dr. Anja Jetschke

Tag der mündlichen Prüfung: 27.09.2017 


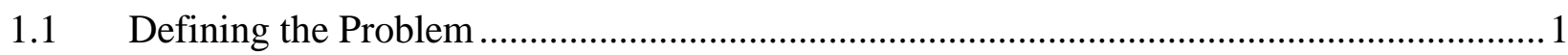

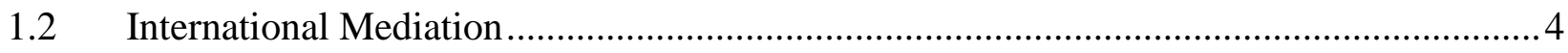

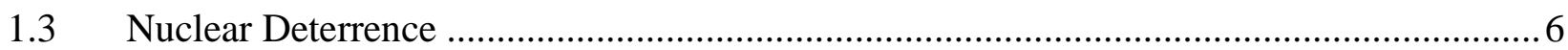

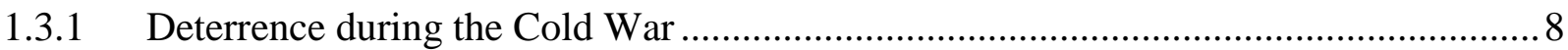

1.3.2 Nuclear Deterrence in the Post-Cold War................................................................. 11

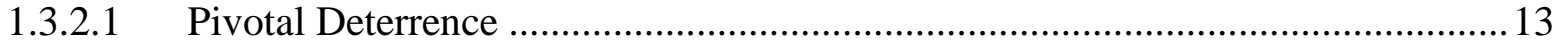

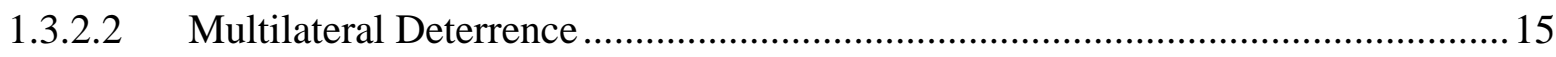

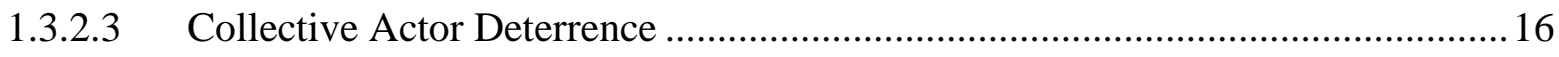

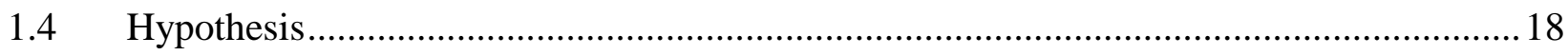

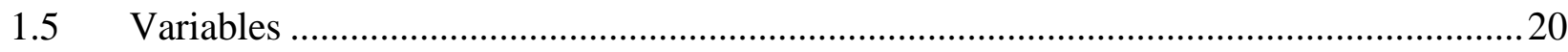

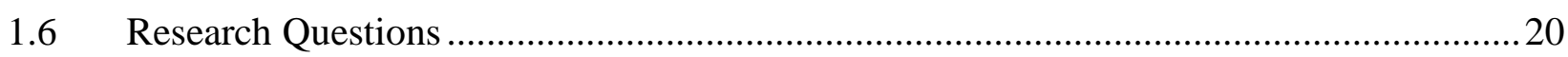

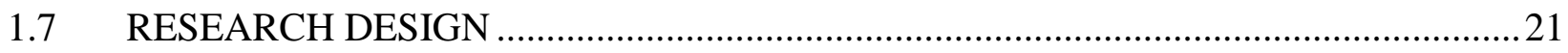

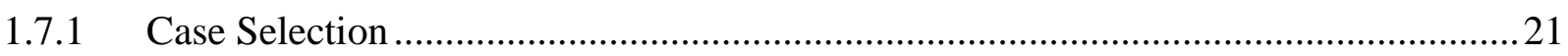

1.7.2 The Dyadic Crises as Other Possible Cases ................................................................ 21

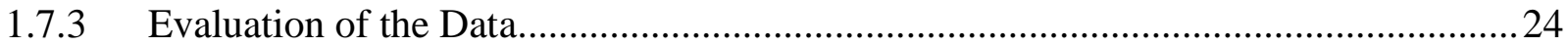

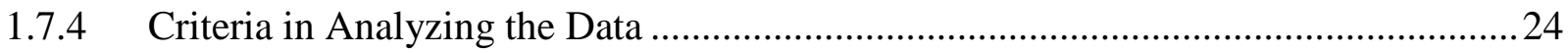

1.7.4.1 First Group of Cases: Nonnuclear Phase ........................................................24

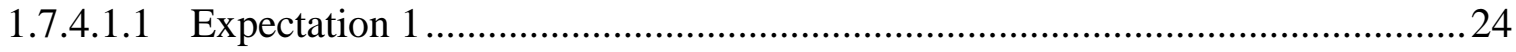

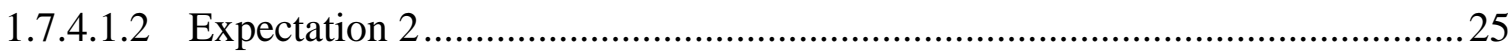

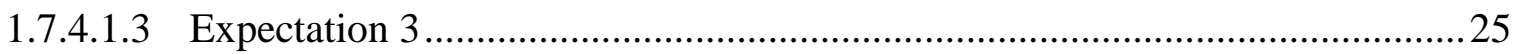

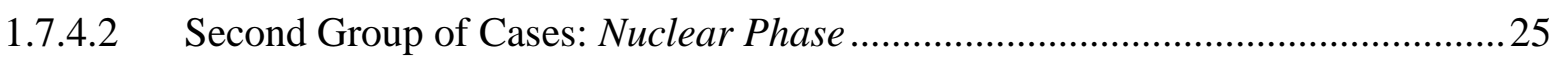

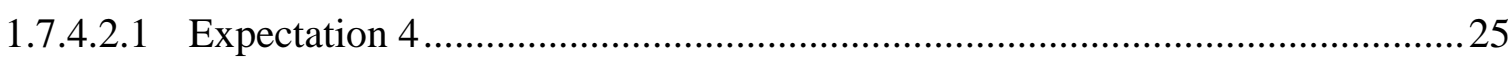

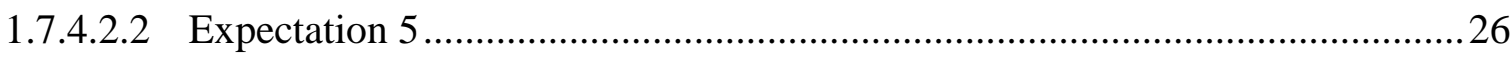

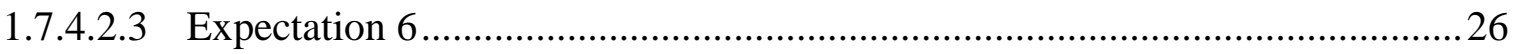

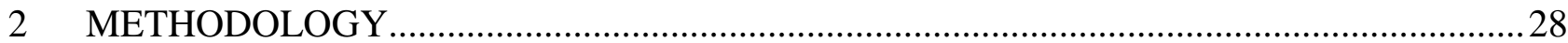




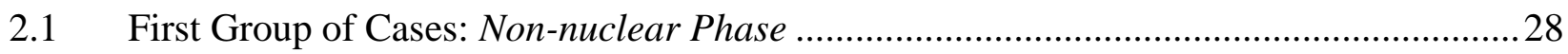

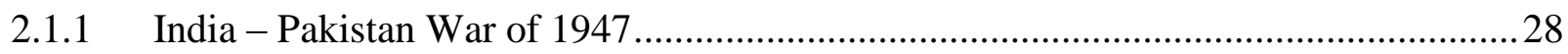

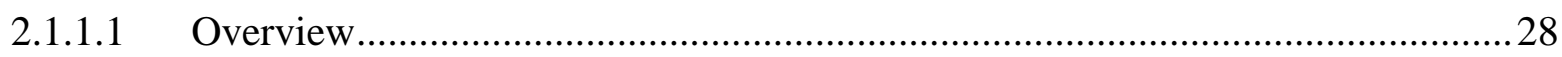

2.1.1.2 The US Mediation................................................................................... 32

2.1.1.3 The Soviet Mediation ................................................................................ 33

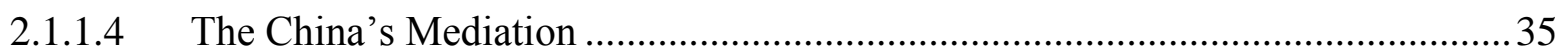

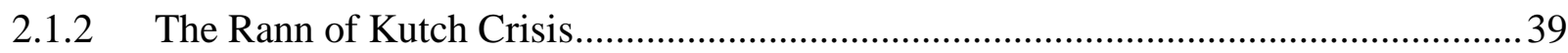

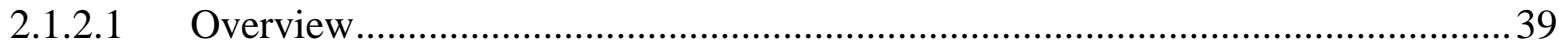

2.1.2.2 US Mediation of the Rann of Kutch Crisis....................................................... 40

2.1.2.3 Soviet Mediation of the Rann of Kutch Crisis................................................ 42

2.1.2.4 Chinese Mediation of the Rann of Kutch Crisis ............................................. 42

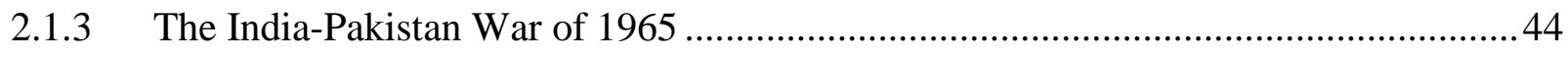

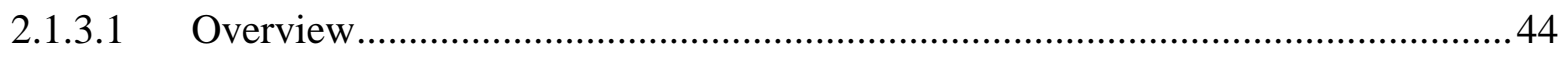

2.1.3.2 US Mediation of the India - Pakistan War of 1965 ........................................... 45

2.1.3.3 The Soviet Mediation of India - Pakistan War of 1965 .................................... 49

2.1.3.4 The Chinese Mediation of Indian - Pakistan War of 1965 ................................53

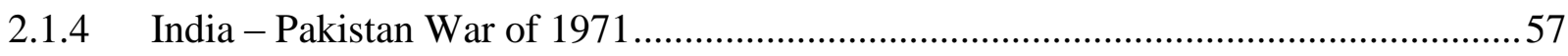

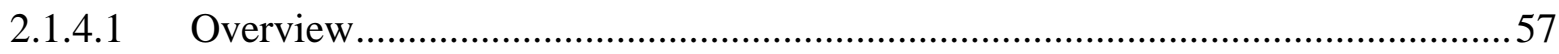

2.1.4.2 US Mediation of India - the Pakistan War of 1971 ...........................................59

2.1.4.3 The Soviet Mediation of India - Pakistan War of 1971 .....................................61

2.1.4.4 Chinese Mediation of the India - Pakistan War of 1971 .....................................64

2.2 The Second Group of Cases: Nuclear Phase …........................................................ 67

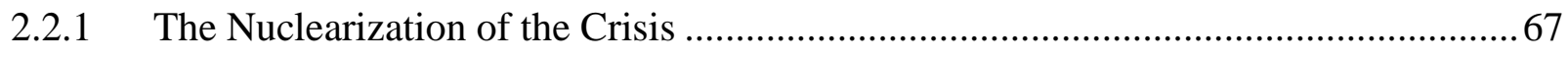

2.2.2 The Crises at the Beginning of 1980s and Kahuta Crisis ........................................ 73

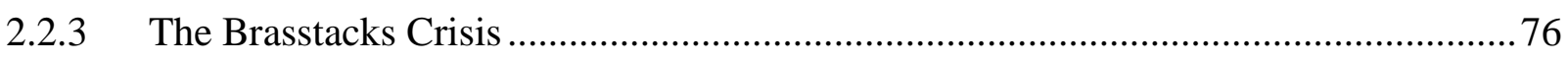

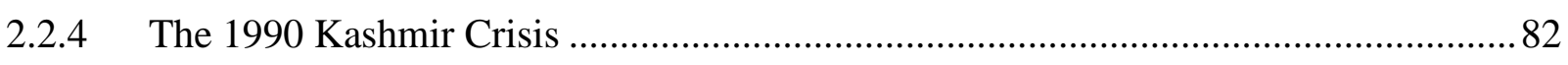

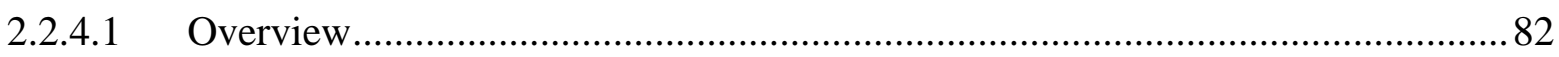

2.2.4.2 US Mediation of the 1990 Kashmir Crisis: .................................................... 85 
2.2.4.3 The Soviet Mediation of 1990 Kashmir Crisis ................................................. 88

2.2.4.4 Chinese Mediation of the 1990 Kashmir Crisis................................................. 91

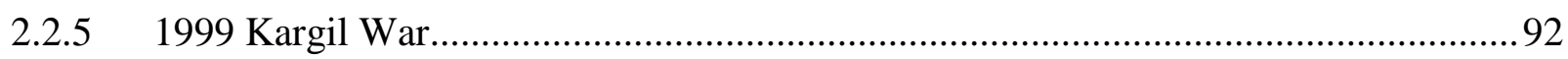

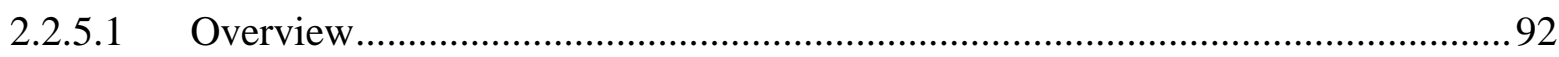

2.2.5.2 US Mediation of the 1999 Kargil War .......................................................... 94

2.2.5.3 Russian Mediation of 1999 Kargil War......................................................... 97

2.2.5.4 Chinese Mediation of the 1999 Kargil War......................................................... 98

2.2.6 Attacks on the Indian Parliament in 2001 and the Military Standoff ....................... 100

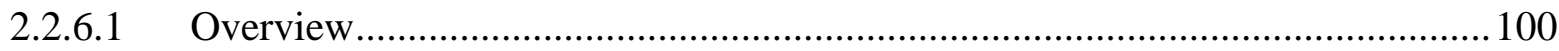

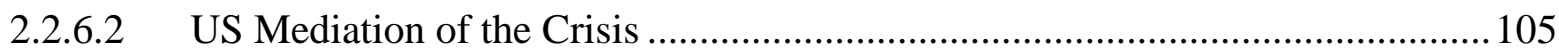

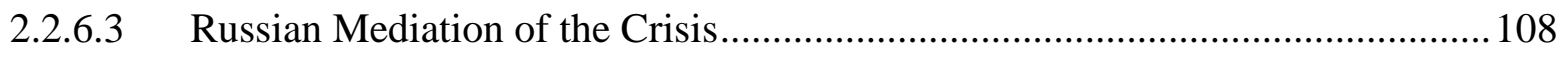

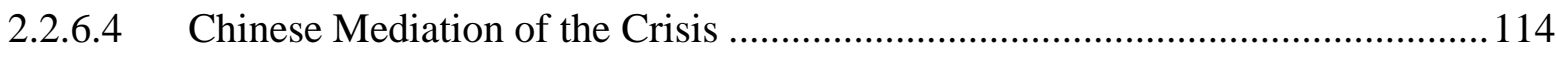

2.2.7 Mumbai Terrorists Attacks in November 2008 .................................................. 117

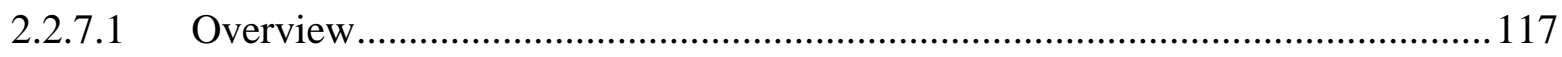

2.2.7.2 US Mediation of the 2008 Mumbai Crisis...................................................... 119

2.2.7.3 Russian Mediation of the 2008 Mumbai Crisis ............................................... 120

2.2.7.4 The Chinese Mediation of 2008 Mumbai Crisis............................................ 121

2.3 Complementary / Discussion Cases ….............................................................. 123

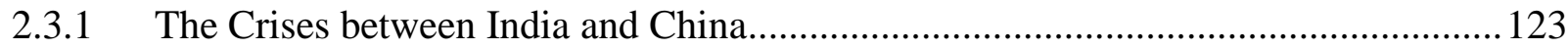

2.3.2 The Relations between the US, Russia, and China in the Post-Cold War Era........... 129

2.3.2.1 The Competition in Balkans .................................................................... 129

2.3.2.2 The Competition in Central Asia ............................................................... 131

2.3.2.3 The Competition in the South China Sea ................................................. 133

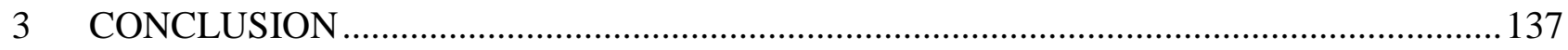

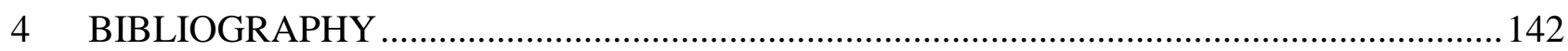




\section{Double Deterrence and International Mediation}

\section{INTRODUCTION}

\subsection{Defining the Problem}

The body of literature on international mediation is large and comprehensive, with studies that analyze different facets of mediation ranging from the role of mediators, mediation tactics to the mediation success. The research on nuclear deterrence is also very advanced. There are ample studies which focus on nuclear deterrence mechanisms, types of deterrence, and which analyze the functioning principles of nuclear deterrence. Most of the research, however, neglects the possibility of a nexus between international mediation and nuclear deterrence theory. The research gap is twofold. First, there is a scarcity of research analyzing the relationship between various types of crises and international mediation, especially between nuclear crises and the pattern of international mediation. The second gap concerns the nuclear deterrence effect that may emerge through international mediation, and is conducted by more than one major state possessing nuclear capability. The purpose of this dissertation is to address these two gaps by analyzing the connection between nuclear deterrence and international mediation.

More specifically, in this study, I explore the question of whether the nuclear dimension of the conflict can influence the way in which international mediation occurs. I will also examine whether international mediation creates deterrence effects on the conflicting parties other than the direct deterrence between them. This research will therefore identify whether there is a place in nuclear deterrence research to include the mechanism of international mediation into its analysis.

The lack of research on the connection between international mediation and nuclear deterrence is puzzling, especially among nuclear deterrence studies because there is an increasing number of studies that approve the stability-instability paradox created by the stability at the nuclear level. The main argument of the stability-instability paradox is that the parties of the conflict rely on their nuclear capabilities to deter a massive attack from the adversary, which stabilizes relations at the nuclear level. Stability at the nuclear level caused an increasing number of crises at the conventional level. Snyder articulated the stability-instability paradox as "the greater the stability of the "strategic" balance of terror, the lower the stability of the overall balance at its lower levels of 
violence." ${ }^{1}$ Snyder analyzed this paradox in the context of US-Soviet relations. He asserted that the Soviet Union could get involved in "a range of minor ventures which they can undertake with impunity, despite the objective existence of some probability of retaliation." ${ }^{2}$ In another study, Snyder and Diesing asserted that the crises became surrogates for war since war was no longer a possibility between the nuclear powers. ${ }^{3}$ Jervis defined the stability-instability paradox as, "To the extent that the military balance is stable at the level of all-out nuclear war, it will become less stable at lower levels of violence." ${ }^{4}$ Geller asserted that even in the crises that only one side has nuclear capabilities, there is room for conflict escalation because the nonnuclear opponent does not always limit its escalatory behavior. ${ }^{5}$ Rachhaus also found supportive evidence for the stability-instability paradox, arguing that nuclear weapons lead to more risk-taking actions in lower intensity disputes. However, he argues that in symmetric conflicts, where both adversaries have nuclear weapons, the probability of war is smaller than asymmetric conflicts, where only one side of the conflict has nuclear weapons. ${ }^{6}$

These studies demonstrate that the relations between adversaries are stabile at the nuclear level; nevertheless, there are recurrent crises at the conventional level. As such, there is a greater need for mediation at times of nuclear crises, as well as the consideration of the nexus between international mediation and nuclear deterrence. One can also observe this nexus in the context of India - Pakistan crises as well. The major powers, for example, presented a competitive behavior in their mediation attempts to the crises between India and Pakistan. However, they did not compete in the later periods of the crises between India and Pakistan. This represents a puzzling situation. Is it possible that the change in mediation behavior stems from the added nuclear dimension of the conflict? If so, did this new pattern of international mediation create a second deterrence effect on India and Pakistan other than the direct deterrence between them? Alternatively, I also analyze whether this new international mediation pattern provided opportunities for India and Pakistan to back down from the conflict.

Although the Indo-Pakistani conflict has been a subject of numerous studies in the fields of international mediation and nuclear deterrence, these studies have not considered the node between

\footnotetext{
${ }^{1}$ Snyder, G.H. (1965). The Balance of Power and the Balance of Terror in Paul Seabury (ed.) The Balance of Power. Scranton: Chandler, pp. 198-199.

${ }^{2}$ Snyder, G.H. (1961). Deterrence and Defense: Toward a Theory of National Security. The US: Princeton University Press, p. 226.

${ }^{3}$ Snyder, G.H. and Diesing, P. (1977). Conflict Among Nations: Bargaining, Decision Making, and System Structure in International Crises. New Jersey: Princeton University Press, pp. 455-456.

${ }^{4}$ Jervis, R. (1984). The Illogic of American Nuclear Strategy. Cornell University Press: Ithaca, New York, p. 31.

${ }^{5}$ Geller, D.S. (1990). Nuclear Weapons, Deterrence, and Crisis Escalation. Journal of Conflict Resolution, Vol. 34, No.2, Jun 1990, p. 307.

${ }^{6}$ Rauchhaus, R. (2009). Evaluating the Nuclear Peace Hypothesis: A Quantitative Approach. Journal of Conflict Resolution, Vol. 53, No. 2, April 2009, p. 258.
} 
international mediation and nuclear deterrence. International mediation research analyzes the crises between India and Pakistan mainly under the conditions of conventional world, and does not analyze whether the nuclear dimension of the conflict changed the pattern of mediation. Nuclear deterrence research, on the other hand, examines the direct deterrence between India and Pakistan. They compare the deterrence between India and Pakistan with the deterrence between the US and the Soviet Union in the Cold War. Some studies found that the deterrence between India and Pakistan is sustainable as it was in the case between the US and the Soviet Union. ${ }^{7}$ Other studies, however, found that the deterrence between the two countries rather fragile. ${ }^{8}$ However, they neglected the possible deterrence effect from the international mediation led by major states, and its impact on the crisis between India and Pakistan.

The crisis situation is particularly more complex in crises in which parties of a conflict have opaque nuclear capabilities and do not know the whereabouts of the nuclear weapons of other side. There is also a great risk of miscalculation especially at the initial stages of the nuclearization of the conflict. If one party of the conflict has nuclear capabilities, and the other one is at the threshold of having one, then there may be a risk of preemptive attack by the former party with nuclear capabilities. ${ }^{9}$ This was also the situation in the Indo-Pakistani conflicts. India conducted a nuclear test in 1974, and Pakistan had opaque nuclear capabilities during the 1980s. There was a high likelihood of an Indian preemptive attack during the 1980s, but India refrained from it. For this reason, it is compelling to analyze the impact that international mediation had on the direct deterrence between India and Pakistan.

This study addresses the nexus between international mediation and nuclear deterrence. It is therefore necessary to review the literature in both international mediation and nuclear deterrence fields. I will first start with international mediation.

\footnotetext{
${ }^{7}$ Some of these studies are Singh, J. (1998). Against Nuclear Apartheid. Foreign Affairs, Vol. 77, No.5, Sept-October 1998, pp. 41-52; Dixit, J.N. (2002). India - Pakistan in War \& Peace. Routledge, London and New York: Taylor \& Francis Group pp. 322-346; Sundarji, K. (1995). Proliferation of WMD and the Security Dimensions in South Asia: An Indian View in William H. Lewis and Stuart E. Johnson (eds.) Weapons of Mass Destruction: New Perspectives on Counterproliferation. Washington D.C.: National Defense University Press, p. 55; Chengappa, R. (2000). Weapons of Peace: the secret story of India's quest to be a nuclear power. New Delhi: Harper Collins Publishers; Hagerty, D.T. (1998). The Consequences of Nuclear Proliferation: Lessons from South Asia. Cambridge, MA: The MIT Press.

${ }^{8}$ Some of these studies are Joeck, N.(1997). Maintaining Nuclear Stability in South. Asia Adelphi Paper 312 , Routledge: Taylor \& Francis Group: London and New York; Raghavan, V.R. (2001). Limited War and Nuclear Escalation in South Asia The Nonproliferation Review, Volume 8 Number 3 Fall/Winter 2001, Heisbourg, F. (1998). The Prospects for Nuclear Stability between India and Pakistan. Survival, Volume 40 Issue 4 pp.77-92; Tellis, J.A. (2002). The Strategic Implications of a Nuclear India. Orbis, Volume 46, Issue 1, Winter 2002, pp. 13-45.

${ }^{9}$ For more information about US considerations of preventive and preemptive attacks in the Cold War see: Mueller, K.P. et.al. (2006). Striking First: Preemptive and Preventive Attack in U.S. National Security Policy. The US: RAND Cooperation pp. 121- 182. [online] Available at: http://www.rand.org/content/dam/rand/pubs/monographs/2006/RAND_MG403.pdf [Accessed 23.03.2017].
} 


\subsection{International Mediation}

The definitions of international mediation are diverse, ranging from one-party mediation to multi-party mediation. Generally, mediation is defined as a practice where an outside party undertakes to bring or preserve a peace. ${ }^{10}$ Zartman and Touval emphasized that mediation should facilitate ways of communication which parties of the conflict are unable to reach without the mediator. ${ }^{11}$ Bercovitch widened the definition of mediator by including individuals, groups, and organizations as mediators, in addition to states. Bercovitch highlighted that the parties of a conflict should request the help of these actors to mediate without resorting to physical force. ${ }^{12}$ The recent definition of mediation also included the mediation of multiple actors, manifesting itself as the simultaneous interventions of more than one state, or the interventions of regional organizations and nongovernmental organizations. ${ }^{13}$

Several studies have analyzed the capabilities of mediators, claiming that a strong mediator is necessary for successful mediation. Mediators, whom adversaries perceive as highly skilled, could influence adversaries to accept the proposed solution. ${ }^{14}$ Skilled mediators are able to compel adversaries to make concessions, and can force them to adhere to agreements. Bercovitch, Anagnoson and Wille pointed out that those mediators, who possess resources and who employ active mediation strategies, are most successful in abetting a crisis. ${ }^{15}$

In contrast, some studies argue that adversaries actually prefer weak mediators because weak states do not have the power to issue threats. For the stronger party in the conflict, Slim argued that it is easier to meet the domestic political consequences of accepting the agreement terms provided by weak mediators. The weaker party in the conflict is also more likely to sympathize with the weaker mediator. ${ }^{16}$

\footnotetext{
${ }^{10}$ Crocker, C., Hampson, F.O., and Aall, P. (1999). Multiparty Mediation: Concepts, Issues, Strategies, and Actors: Introduction in Chester A. Crocker, Fen Osler Hampson, and Pamela Aall (eds.) Herding Cats: Multiparty Mediation in a Complex World. Washington, D.C.: United States Institute of Peace Press, p. 7.

${ }^{11}$ Zartman, W.I. and Touval, S. (1996). International Mediation in the Post-Cold War Era in Chester A. Crocker, Fen Osler Hampson, Pamela R. Aall (eds.) Managing Global Chaos: Sources of and Responses to International Conflict. Washington, D.C.: United States Institute of Peace Press, p. 446.

${ }^{12}$ Bercovitch, J. (2007). Mediation in International Conflicts: Theory, Practice and Developments in I. William Zartman (ed.) Peacemaking in International Conflict: Methods \& Techniques. Revised Edition, Washington, D.C.: United States Institute of Peace Press, pp. 167-168.

${ }^{13}$ Crocker, C., Hampson, F.O., and Aall, P. (1999) "Multiparty Mediation: Concepts, Issues, Strategies, and Actors: Introduction" in Chester A. Crocker, Fen Osler Hampson, and Pamela Aall (eds.) Herding Cats: Multiparty Mediation in a Complex World. Washington, D.C.: United States Institute of Peace Press, p. 9-10.

${ }^{14}$ Brookmire, D.A. and Sistrunk, F. (1980). The Effects of Perceived Ability and Impartiality of Mediators and Time Pressure on Negotiation. The Journal of Conflict Resolution, Vol. 24, No.2, June 1980, p. 323.

${ }^{15}$ Bercovitch, J., Anagnoson, J.T., and Wille, D.L. (1991). Some Conceptual Issues and Empirical Trends in the Study of Successful Mediators in International Relations Journal of Peace Research, Vol.28, No.1 Special Issue on International Mediation February 1991, p. 16-17.

${ }^{16}$ Slim, R.M. (1992). Small-State Mediation in International Relations: The Algerian Mediation of the Iranian Hostage Crisis in Jacob Bercovitch and Jeffrey Z. Rubin (eds.) Mediation in International Relations: Multiple Approaches to
} 
Beardsly highlighted another problem associated with strong mediation. In his case studies, Beardly illustrated that strong mediation based on leverage can have negative consequences in the long term, when the mediators lose their interests in the conflict. ${ }^{17}$ Werner and Yuen also emphasized that agreements reached through strong mediator pressure would likely fail in the future if pressure from a mediator decreases because of a decreasing interest in the conflict. ${ }^{18}$

There are also many debates surrounding the timing of mediation. Several studies argue that conflicts should reach a certain level of intensity in order for the mediation to be successful. For example, Zartman put forward the concept of ripeness. He asserted that only if a conflict reached to a certain level of intensity, the parties of the conflict would be more amenable for mediation because of the increasing costs of the conflict. In other words, the disputants should reach a point in which continuing the fight would not pay off. ${ }^{19}$

On the other hand, Bercovitch, Anagnoson, and Wille have asserted that if the conflict lasts for a long time, it becomes less amenable to mediation. They pointed out that an increasing number of fatalities have a negative impact on mediation success. ${ }^{20}$ Greig and Regan claimed that increase in the duration of a conflict, rather than an increase in death toll, is the key factor for accepting a mediation offer. $^{21}$

There are several studies focusing on the intentions and the role of the mediator states for successful mediation. Young argued that a mediator could play a significant role if the adversaries believe that the mediator is impartial and has nothing to gain from the conflict by supporting either of the parties. ${ }^{22}$ Yet, there are also studies that argue that biased mediators are more successful than unbiased mediators are. Both biased and unbiased mediators inform the parties about the resoluteness of the other party. Kyadd argues that the conflicting parties would doubt the reliability of the information given by unbiased mediator because the unbiased mediator is only interested in easing the conflict. An unbiased mediator, therefore, can exaggerate the resoluteness of the other side just to end the crisis. On the other hand, if the mediator favors one party, then this party will

Conflict Management. New York: Palgrave Macmillan, p. 207.

${ }^{17}$ Beardsly, K. (2011). The Mediation Dilemma. The US: Cornell University Press.

${ }^{18}$ Werner, S., and Yuen, A. (2005). Making and Keeping Peace. International Organization Vol. 59, No.2, Spring, 2005 p. 289.

${ }_{19}$ Zartman, I.W. (1985/1989) Ripe for Resolution: Conflict and Intervention in Africa. Oxford University Press: New York. and Zartman, I.W. (2008) “ The Timing of Peace Initiatives: hurting stalemates and ripe moments" in Darby, J. and MacGinty, R. (eds.) Contemporary Peacemaking: Conflict, Peace Processes and Post-War Reconstruction. New York: Palgrave MacMillan, pp. 22-36.

${ }^{20}$ Bercovitch, J., Anagnoson, J.T., and Wille, D.L. (1991). Some Conceptual Issues and Empirical Trends in the Study of Successful Mediation in International Relations. Journal of Peace Research, Vol.28, No.1 Special Issue on International Mediation, February 1991, p.13.

${ }^{21}$ Greig, M.J., and Regan, P.M. (2008). When Do They Say Yes? An Analysis of the Willingness to Offer and Accept Mediation in Civil Wars. International Studies Quarterly, Vol. 52, No.4, December 2008, p. 776.

${ }_{22}$ Young, O.R. (1967). The Intermediaries: Third Parties in International Crises. Princeton, New Jersey: Princeton University Press, p. 81. 
find the information given by the mediator more reliable. This increases the effectiveness of the biased mediator to convince the party, to which it favors, to make compromises. ${ }^{23}$

Touval and Zartman argue that mediators are rarely unbiased. Mediators prefer an outcome, which concurs with their own interests ${ }^{24}$, and they use mediation as a tool in power politics to represent these interests. ${ }^{25}$ A recent study by Bercovitch and Jackson also confirmed this point. They argued that mediators have their own agenda about the conflict, and they bring their own knowledge, resources, and interests to the conflict. ${ }^{26}$ This finding is crucial for my research because the major powers mediating the crises between India and Pakistan were competitive. They brought their own agendas and interests to the conflict. In the crises after the 1980s, however, this competitive behavior is not visible, which poses a puzzling situation.

The literature review on international mediation demonstrates that there exists sufficient research with respect to the role and the intentions of mediators, negotiation tactics, and the capability of the mediators. There are also several studies focusing on the necessary conditions for a successful international mediation. There is also sufficient research regarding the mediation of more than one state, called multi-party mediation. The research gap is then, literature that takes into account the nuclear aspect of the conflict and its influence on the international mediation.

To illustrate the deterrence effect that may emerge from international mediation - the second gap in the literature - it is necessary to briefly summarize the research in the nuclear deterrence field. In the following paragraphs, I outline several definitions of nuclear deterrence, and will define the various types of nuclear deterrence. Subsequently, I will provide some historical information about the emergence and the development of the nuclear deterrence concept, in both the Cold War and the Post-Cold War periods. Providing a historical context of nuclear deterrence is necessary in order to demonstrate the place of this research in the literature, and to demonstrate how this research will contribute to the nuclear deterrence concept as well.

\subsection{Nuclear Deterrence}

Nuclear deterrence depicts a situation where the devastating effects of nuclear weapons deter both parties of the conflict from attacking. The gains are much smaller than losses even for the winner, which can only aspire a Pyrrhic victory. Therefore, the main assumption of the deterrence

\footnotetext{
${ }^{23}$ Kydd, A. (2003). Which Side Are You On? Bias, Credibility, and Mediation. American Journal of Political Science, Vol. 47, No.4, October 2003 p. 597-598.

${ }^{24}$ Touval, S. and Zartman, I. W. (1989). "Mediation in International Conflicts" in Kenneth Kressel and Dean G. Pruitt (eds.) Mediation Research: The Process and Effectiveness of Third-Party Intervention. San Francisco: Jossey-Bass, p. 118 .

${ }^{25}$ Touval, S. and Zartman, I. W. (1989). “Mediation in International Conflicts, p. 129.

${ }^{26}$ Bercovitch, J and Jackson, R. (2009). Conflict Resolution in the Twenty-first Century: Principles, Methods, and Approaches. Ann Arbor, the US: The University of Michigan Press, pp. 33-34.
} 
logic is that there are no actual winners of a conflict, and actually, both sides are the losers. Snyder described deterrence as discouraging the enemy from taking military action by demonstrating that the costs and risks of attack outweigh the gains. ${ }^{27}$ Morgan defines deterrence as "the use of threats of harm to prevent someone from doing something you do not want him to."28

Different types of nuclear deterrence emerged through geopolitical developments during the Cold War. This categorization is helpful not only for pursuing a clear scholarly discussion, but also in order for policymakers to provide rigorous policy recommendations. Below, I describe the most important types of nuclear deterrence.

Direct Deterrence: Direct deterrence is deterrence between both parties of the conflict. For example, deterrence posed by the US and the Soviet Union in the Cold War.

Extended Deterrence: Extended deterrence means that one actor deters another actor from attacking a third actor. ${ }^{29}$ For example, the US security guarantees to Western Europe against Soviet Union were described as extended deterrence.

Massive Retaliation: The Eisenhower administration declared a solid nuclear strategy, believing that a strong nuclear deterrence capability is cheaper than providing massive conventional forces for the protection of allies. The policy targeted the Soviet Union in order to protect US soil as well as US allies. ${ }^{30}$ The then US Secretary of State Dulles described massive retaliation as preserving the capacity to retaliate immediately to the places wherever the US chooses, and by using any means the US decides. ${ }^{31}$

Mutual Assured Destruction: Assured destruction capability is the capability to deter a nuclear attack by preserving the ability to cause unacceptable damage on aggressor, even after receiving the first surprise attack. ${ }^{32}$ The proposed idea was that deterring the Soviets would not necessarily requires keeping giant nuclear capabilities. Keeping the ability to destroy 33-20 percent of the Soviet population and 75-50 percent of industrial capacity would be enough to deter any

\footnotetext{
${ }^{27}$ Snyder, G.H. (1961). Deterrence and Defense: Toward a Theory of National Security. The US: Princeton University Press, p. 3.

${ }^{28}$ Morgan, P.M. (1977). Deterrence: A Conceptual Analysis. The US: SAGE Publications, p. 17.

${ }^{29}$ Weede, E. (1983). Extended Deterrence by Superpower Alliance. The Journal of Conflict Resolution, Vol. 27, No.2, June 1983, pp. 234-235.

${ }^{30}$ Pifer, S., Bush, R.C., Felbab-Brown, V. (et al.) (2010). U.S. Nuclear and Extended Deterrence: Considerations and Challenges Brookings Arms Control Series, Paper No: 3, 2 May 2010, p. 4. [online] Available at: https://www.brookings.edu/wp-content/uploads/2016/06/06_nuclear_deterrence.pdf [Accessed 15.02.2017].

${ }^{31}$ US Department of State Bulletin The Evolution of Foreign Policy Address by Secretary Dulles US Department of State Bulletin Vol. XXX, No. 761 Publication 5349, 25 January 1954, pp. 107-110. cited in Freedman, L. (1981/1989). The Evolution of Nuclear Strategy. The International Institute for Strategic Studies, London: The Macmillan Press Ltd., Printed in The People's Republic of China, p. 85.

${ }^{32}$ Enthoven, A.C. and Smith, K. W. (1971/2005). How Much Is Enough: Shaping the Defense Program 1961-1969 RAND Cooperation: The US. p. 174. [online] Available at:

http://www.rand.org/content/dam/rand/pubs/commercial_books/2010/RAND_CB403.pdf [Accessed 27.03.2017].
} 
Soviet attack. ${ }^{33}$ Assuming that the Soviets would also make similar calculations, and preserve the same capabilities, it would leads to a situation called "mutual assured destruction." 34

\subsubsection{Deterrence during the Cold War}

The theory of nuclear deterrence first gained prominence during the Cold War. The main goal of first deterrence theorists was to find strategies to deter Soviet attacks on US soil or on US allies. Brodie, one of the first theorists who wrote about the concept of nuclear deterrence in the Cold War, argued that the effects of nuclear weapons on war making are so enormous that the chief purpose of a military apparatus is not any more winning wars, but trying to find strategies to avert them. ${ }^{35}$ Synder agreed with Brodie that nuclear weapons have tremendous impact in war-fighting strategies. In the pre-nuclear era, Snyder asserts that the states used the same weapons for both offensive and defensive purposes. In the nuclear era, one uses mainly nuclear weapons to deter, however, it is not rational to provide defense with nuclear weapons if deterrence fails and the adversary state attacks. Therefore, Snyder asserts, in the nuclear era states must choose a policy between deterrence and defense. ${ }^{36}$

Deterrence theorists in this period followed the rational model, basing their assumptions on deductive models and abstract logic. For example, Schelling applied game theory in nuclear deterrence. ${ }^{37}$ Wohlsteter also emphasized the rationality assumption; however, he also added that deterrence is not a situation that is automatically sustained. Deterrence requires the active involvement of states, and entails the development of new strategies which is relevant to the necessities of new weapons systems. ${ }^{38}$

After enthusiasm for the deterrence effect of nuclear weapons, some scholars began to question the functioning principles of deterrence. These scholars were not necessarily the deterrence critics; however, they were concerned about the credibility of threats. The basic concern was that if a nuclear attack brings catastrophic consequences for both the attacker and the defender, then how would the attacker make a credible nuclear threat? This is especially notable in the deterrence of limited attacks. In this respect, Kahn asserted that the threat of general war to deter minor provocations would make allies uncomfortable, no matter how credible these threats were. If the threat of a general war to minor crises are credible, "the threat is too dangerous to be lived with. If it

\footnotetext{
${ }^{33}$ Freedman, L. (1981/1989). The Evolution of Nuclear Strategy. The International Institute of Peace Studies, London: The Macmillan Press Ltd., Printed in the People's Republic of China, p. 246.

${ }^{34}$ Freedman, L. (1981/1989). The Evolution of Nuclear Strategy, pp. 246-248.

35 Brodie, B. (1946). The Weapon: Implications for Military Policy in Bernard Brodie (ed.) The Absolute Weapon: Atomic Power and World Order. New York: Harcourt, Brace and Company, p. 76.

${ }^{36}$ Snyder, G.H. (1961). Deterrence and Defense, p. 8-9.

${ }^{37}$ Schelling, T.C. (1960). The Strategy of Conflict. The US: Harvard University Press.

${ }^{38}$ Wohlstetter, A. (1959). The Delicate Balance of Terror. Foreign Affairs, Vol. 37, No. 2 January 1959.
} 
is incredible, the lack of credibility itself will make the defense seem unreliable." ${ }^{39}$ For this reason, Kahn argues that limited war forces are crucial instruments to tackle minor provocations. ${ }^{40}$

Schelling also studied the credibility concept, making an analogy between threat of launching a nuclear attack and two men standing on the edge of a cliff roped to each other. Schelling maintains that one should envisage the cliff as a curved slope, but not as a sharp cliff. If one stays at the edge of a sharp cliff, then one does not have much room to threaten. One has the decision to jump off or not. If one stands on the edge of a curved slope, then one can gradually threaten. Each step towards the slope incrementally increases the danger of plunging. Therefore, one gives the impression that one does not have a complete control in the process. Even if one does not want to jump off, he can slip, and with every incremental step towards the slope, danger of slipping accidentally increases. Schelling argues that this gives greater credibility because if the rival knows that one does not have control of the whole process, then every provocative move presents the danger of accidental war. Therefore, the rival state would be more concerned and would think twice before acting. Schelling therefore argued that the threat that leaves something to chance is more credible than the threat where each side has full control of its actions and decisions. $^{41}$

The discussion about the functioning principles of nuclear deterrence, above, demonstrate that the realist thought was dominant among the scholars in the early period of the Cold War. Realism takes the unitary structures of states and this supports the usage of abstract logic. During the 1970s, some scholars criticized the unitary and rational behavior assumption of states in realist thought. In order to show that government leaders do not always act rationally, Jervis analyzed the perceptions of national leaders by applying cognitive psychology to historical cases. ${ }^{42}$ Lebow also analyzed the rationality of policy-makers and analyzed reasons that may cause policy-makers to miscalculate their decisions. ${ }^{43}$ Allison also questioned the unitary model of states assumed in realist theory. He instead argued that state actions are the consequences of negotiations between selfinterested sub-state actors such as organizations and bureaucratic elites. ${ }^{44}$ The sub-state actors are primarily parochial and mainly concentrate on their own interests during the decision-making process. $^{45}$

\footnotetext{
${ }^{39}$ Kahn, H. (1960). On Thermonuclear War. The US: Princeton University Press, p. 155.

${ }^{40}$ Ibid.

${ }^{41}$ Schelling, T.C. (1960). The Strategy of Conflict. The US: Harvard University Press, pp. 199-200.

42 Jervis, R. (1976). Perception and Misperception in International Politics. The US: Princeton University Press,

${ }^{43}$ Lebow, R.N. (1981). Between Peace and War: The Nature of International Crisis. The US: John Hopkins University Press.

${ }^{44}$ Allison, G. (1969). Conceptual Models and the Cuban Missile Crisis. The American Political Science Review, Vol. 63, No. 3, September 1969, p. 63.

${ }^{45}$ Allison, G. (1971). Essence of Decision. Boston: Little, Brown and Company, pp. 164-171.
} 
Neorealist analyses of nuclear deterrence also brought the rationality concept to the forefront. Waltz claimed that wars are based on rational calculations. Since starting a war is not rational anymore, the probability of a major war among states possessing nuclear weapons is almost zero. ${ }^{46}$ Waltz maintained that the world has not witnessed a general war among major powers since the Second World War. Rather, the peace among major powers has been sustained, and wars only occurred in the peripheries. He asserts that states are rational actors trying to increase their security. In a nuclear war, gains are marginal, but losses are catastrophic. He even argued that the steady increase in the number of nuclear states is better than not increasing, or a sudden increase. ${ }^{47}$ Therefore, it is not rational to conduct wars. For nuclear states, nuclear weapons are only for deterrence, not for actual use. ${ }^{48}$ Waltz emphasized the system level conditions. He argued that the international structure put some restraints on nuclear actor. In my argument, however, rather than the structure of the international system, the character of the conflict plays a predominant role. Regardless of whether the structure of the international system is bipolar, tri-polar or multipolar, the character of the conflict is decisive in forming the international mediation pattern. For this reason, I analyze the crises between India and Pakistan, from their independence until to present day. The conflict between them has survived the bipolar, tri-polar - China also emerged as a nuclear power during the Cold War - and emerging multi-polar structure.

In analyzing the deterrence effect of nuclear weapons, Waltz underestimates the impact of low-level crises on crisis stability. Waltz actually appreciates the stability-instability paradox. He also accepts that low scale wars can occur despite the existence of nuclear capabilities. He, however, argues that it is a fair price to pay, compared to the price of war which could occur at high levels. ${ }^{49}$ However, while one low level crisis may have a small price, if the frequency of low level crises increases, then it may burden the stability at the nuclear level. In this respect, the role of international mediation becomes critical for mitigating nuclear crisis, and conflict resolution should not be left only to the deterrence mechanism between the parties of the conflict.

There are also some scholars who emphasized the role that the memories of historical experiences could play in mitigating the crisis. For example, Müller doubted the relationship between nuclear weapons and the nonexistence of major wars. According to Müller, what prevents another great war from occurring are not nuclear weapons, but the memory of World War II and the

\footnotetext{
${ }^{46}$ Waltz, K.N. (1990). Nuclear Myths and Political Realities. The American Political Science Review, Vol. 84, No.3, September 1990, p. 740.

${ }^{47}$ Waltz, K.N. (1981). The Spread of Nuclear Weapons: More May Be Better. The Adelphi Papers. Vol. 21 No.171, London: International Institute for Strategic Studies.

${ }^{48}$ Waltz. K. (1990) "Nuclear Myths and Political Realities. The American Political Science Review Vol. 84, No.3, September 1990, p. 734.

${ }^{49}$ Sagan, S. and Waltz, K.N. (2003). Indian and Pakistani Nuclear Weapons: For Better or Worse? Chapter 3 in Scott D. Sagan and Kenneth N. Waltz The Spread of Nuclear Weapons. New York: Norton, p. 122.
} 
contentment of both the Soviet Union and the US with the status quo that emerged after World War II. $^{50}$ The second part of Müller's argument, however, does not explain the absence of a great war between major powers after the Cold War.

In short, during the Cold War, scholars analyzed the functioning principles of deterrence, mainly debating over how states should issue threats in order to sustain credibility. Other discussions emerged around the rationality concept. There were also discussions regarding the unitary notion of the state. Next, I will analyze the deterrence studies in the post-Cold War period.

\subsubsection{Nuclear Deterrence in the Post-Cold War}

Most studies published after the Cold War analyzed the differences between bipolar and unipolar or emerging multipolar world, and discussed which world order is better for the nuclear deterrence to function. They collectively sought to answer questions such as whether new world order after bipolarity was good or bad for nuclear deterrence. For example, Van Creveld was optimistic about nuclear deterrence after the Cold War. He claimed that in the places of the world where nuclear weapons have been introduced, large-scale warfare has disappeared. ${ }^{51}$ In contrast, Campbell drew a pessimistic picture. He argued that the world is approaching a situation in which there are more nuclear states and more war possibilities. ${ }^{52}$

MccGwire notes that nuclear weapons sustained the stability in the Cold War. MccGwire, however, argues that this stability is no longer sustainable in the multipolar world because the restricted control and command systems of new nuclear states make nuclear war a greater possibility. ${ }^{53}$ Friedberg highlighted that especially in some parts of the world such as in Asia, complex situations can emerge. He claims that Asia seems similar to $19^{\text {th }}$ century Europe in the sense that small crises can lead to big crises. For this reason, possessing nuclear weapons pose a great danger. ${ }^{54}$ Wilson challenges the relevancy of deterrence in preventing wars and questions the role of nuclear weapons, even in context of the Cold War. He rejects the direct link between the existence of nuclear weapons and the absence of wars, stating that throughout history, there are simply periods without major wars. For example, after the Thirty Years' War and the Napoleonic

\footnotetext{
${ }^{50}$ Mueller, J. (1988). The Essential Irrelevance of Nuclear Weapons: Stability in the Postwar World. International Security, Vol. 13, No. 2, Fall 1988, p. 56.

${ }^{51}$ Van Creveld, M. (1993). Nuclear Proliferation and the Future of Conflict. New York: Free Press, p. 124.

${ }^{52}$ Campbell, K.M., Einhorn, R.J., Reiss M.B. (2004). Tipping Point: Why States Reconsider Their Nuclear Choices. The US: Brookings Institution, p. 4.

${ }^{53}$ MccGwire, M. (2000). The Elimination of Nuclear Weapons in John Baylis and Robert O`Neill (eds.) Alternative Nuclear Futures: The Role of Nuclear Weapons in the Post-Cold War. New York: Oxford University Press, p. 152.

${ }^{54}$ Friedberg, A.L. (1993/1994). Ripe for Rivalry: Prospects for Peace in a Multipolar World. International Security, Volume 18, Number 3, Winter 1993/1994, p.31.
} 
Wars, there was a time in Europe where peace was the dominant state of affairs. ${ }^{55}$ Wilson, therefore, maintains that it is not prudent to link peace directly to the existence of nuclear weapons.

Both the pessimistic and optimistic arguments may have their own merits. However, they all analyze the deterrence concept under the constellation of two dyadic states, and do not consider the possibility that the nuclear aspect of the crisis can influence the pattern of international mediation.

In the post-Cold War era, one fundamental criticism of the unitary structure of states comes from Sagan. Sagan applied organizational theory to the nuclear proliferation context in order to demonstrate the unreliability of deterrence logic. Sagan emphasized the idea that subunits in organizations pursue their own interests and compete with one another. Therefore, in some cases, a final decision may not be rational, but it reflects the interests of self-interested groups and subunits in organizations. ${ }^{56}$ Sagan states that in the nuclear proliferation framework, the sub-state actors such as military organizations may be inclined to influence the decision-making apparatus to increase their own gains. ${ }^{57}$

Another fundamental critique to realism and neorealism in the post-Cold War period came from Alexander Wendt. Wendt accepts the basic realist assumption of anarchy. However, he challenges the assumption that the anarchic structure leads automatically to a self-help institution. States do not perceive each other as hostile or friendly a priori. Wendt argues that states first interact with each other, and only after interaction does the image of friend or enemy emerge. Wendt considers this interaction as a process. He therefore argues that the process of interaction not the anarchic structure of the international system - creates the self-help system. ${ }^{58}$ However, he should have considered that the conditions under which the interactions take place could also play an important role. In other words, the structure of the system may have an enormous influence on how the interactions between states occur in the first place. States may not have hostile attitudes against each other a priori. However, the structure of the system could still influence how the first interactions take place. It is hard to imagine an interaction of states independent of the structure of the international system. There are also several other constructivist studies held in the post-Cold War era. They analyze the influence of ideas and beliefs on policy-making, highlighting that changes in norms can affect how states view the role of nuclear weapons and their role in deterrence. For example, Tannenwald noted that some US generals considered using nuclear

\footnotetext{
${ }^{55}$ Wilson, W. (2008). The Myth of Nuclear Deterrence. Nonproliferation Review, Vol. 15, No.3, November 2008 , p. 433.

${ }^{56}$ Sagan, S.D. (1994). The Perils of Proliferation: Organization Theory, Deterrence Theory, and the Spread of Nuclear Weapons. International Security, Vol. 18, No. 4 pp. 66-107 cited from p. 73, 74, 86, and 87.

${ }^{57}$ Sagan, S.D. (1994). The Perils of Proliferation. International Security, Vol. 18, No. 4, pp. 102-103.

${ }^{58}$ Wendt, A. (1992). Anarchy is What States Make of It: The Social Construction of Power Politics. International Organization, Vol. 46, No. 2, Spring 1992 p. 394, 405, and 408.
} 
weapons in the Korean War. ${ }^{59}$ General MacArthur wanted to apply an aggressive policy against China, one that even included the use of nuclear weapons. ${ }^{60}$ Rublee stresses that norms regarding the role of nuclear weapons have changed. Therefore, the kind of policy recommendations MacArthur gave at the height of the Korean crisis is no longer conceivable. ${ }^{61}$ However, I would argue that this change in norm could stem from changing security calculations. The US was no longer the sole superpower and had to include nuclear retaliation from the Soviet Union in its security calculations. This threat had tremendous impact on the US view of the role of nuclear weapons in crises.

The theoretical debates discussed above, indicate that the theories of nuclear deterrence are couched in the context of dyadic conflicts; regardless of realist, neorealist or constructivist perspectives. In my dissertation, however, I analyze not only the deterrence between two rival states, but also examine international mediation between them. In the post-Cold War era, however, some scholars started to include third actors into deterrence calculations. The studies about pivotal deterrence, multilateral deterrence and collective actor deterrence also highlighted mediation efforts by third actors in conflicts with a nuclear dimension. I therefore analyze these concepts in detail to distinguish my argument from theirs. As such, I clearly demonstrate the contribution of my study to the literature.

\subsubsection{Pivotal Deterrence}

One can describe pivotal deterrence as a strong third party intervention in dyadic conflicts. ${ }^{62}$ This strong state is called the pivot. Timothy W. Crawford first introduced pivotal deterrence as a concept to explain the third party role in dyadic conflicts. However, he applied pivotal deterrence not only to conflicts with a nuclear dimension, but also to conflicts with a conventional dimension. He proposes that in mediating crises, a pivotal state selects a combination of tactics to ease the situation. He gives examples from history and summarizes these strategies as listed below ${ }^{63}$ :

a-) Threatening the party who can initiate a conflict (Britain's attitude against FrancoGerman Conflict in 1870).

\footnotetext{
59 Tannenwald, N. (1999). The Nuclear Taboo: The United States and Normative Basis of Nuclear Non-Use. International Organization, Vol. 53, No.3, Summer 1999, p. 443.

${ }^{60}$ Ibid. p. 445.

${ }^{61}$ Rublee, M.R. (2009). Nonproliferation Norms: Why States Choose Nuclear Restraints. The US: University of Georgia Press, p. 37.

${ }^{62}$ For further reading about pivotal deterrence see:

Crawford, T.W. (2003). Pivotal Deterrence: Third Party Statecraft and the Pursuit of Peace. Cornell Studies in Security Affairs, the US: Cornell University Press.

${ }^{63}$ Ibid. pp. 6-9.
} 
b-) Threatening to stay neutral, if both side needs the help of a pivotal state to win the conflict (Bismarck’s policy toward Austria - Hungary and Russia Conflict).

c-) Threatening the weakest side that you will stay neutral and threatening the strongest side you will go to war against it (Britain's policy toward France and Germany in July, 1914).

Depending on the power structure between conflicting states, a pivot state has to choose one of the above tactics. Crawford also adds that only a state that possesses the capability of following through on the threat can be a pivot state. ${ }^{64}$

Another vital condition needed in order for pivotal deterrence to function is that the conflicting states should not have any other reliable alignment options. Other alignment options weaken the pivotal state's influence on the conflict's actors. ${ }^{65}$ Crawford evaluated the 1965 Kashmir crisis as an unsuccessful case in which pivotal deterrence did not function. He attributes this failure to the alignment options of India and Pakistan at that time. He argued that India collaborated with the Soviet Union, and Pakistan collaborated with China. This situation weakened the leverage of the US on India and Pakistan. Therefore, the US was not successful in preventing this crisis. ${ }^{66}$

After the end of the Cold War and the disappearance of political camps, states developed more flexible alignment options. For example, If India and Pakistan receive harsh reactions from the US, they may align with China or Russia. One can therefore argue that one of the important conditions by Crawford is no longer valid in the strictest sense. However, in terms of conflicts with a nuclear dimension, major states share the same interest of preventing a nuclear catastrophe. This common interest prevents them from providing different alignment options to either party of the conflict due to the risk of escalating the conflict to a nuclear level. In other words, rival states do not have diverse alignment options during a nuclear crisis. One can therefore argue that the precondition of successful pivotal deterrence - no alignment option of rival states - is still valid in nuclear conflicts, but as already mentioned, pivotal deterrence concentrates on the mediation of only one pivot state. I consider the mediation of more than one state, and focus on the relations between them. I analyze whether they are competitive or collaborative, and whether the pattern of relationship between them can deter crises with a nuclear dimension.

\footnotetext{
${ }^{64}$ Ibid. p. 30.

${ }^{65}$ Ibid. p. 38.

${ }^{66}$ Ibid. pp. 135-169.
} 


\subsubsection{Multilateral Deterrence}

In multilateral deterrence, one assumes that most of the competing interests of the states will eventually converge. Even if one could expect that they converged and actions were taken which resulted in the successful prevention of a nuclear war, the strategies considered by states to this end may differ. In other words, multilateral deterrence assumes a coalition, but even in coalitions it is challenging to reach an agreement within the members regarding the timing and nature of the measures and policies. Therefore, multilateral deterrence accepts that a prior harmony within the members is a necessary condition for the success of multilateral deterrence. ${ }^{67}$ In that respect, sustaining multilateral deterrence is relatively easier in North Atlantic Treaty Organization (NATO) than in the United Nations. (The UN) ${ }^{68}$ Moreover, in the unique unipolar phase of history, the US lost the opportunity to relinquish its duties partially to the UN. Therefore, in the context of an emerging multipolar world, the chance for multilateral deterrence seems dimmer. When one considers the US retreat from the Anti-Ballistic Missile Treaty ${ }^{69}$ or the increasing geopolitical concerns regarding the West and Russia, an institutionalized cooperation becomes harder to achieve. One may expect greater collaboration regarding the preclusion of conflicts with a nuclear dimension. However, there is a decreasing possibility that these collaborations could be institutionalized under the guidance of any international institution with legally binding international agreements. My argument thus pertains to the occasional collaboration of nuclear powers to mediate crises with nuclear elements. Therefore, my argument does not entail a strict cooperation of nuclear states under international institutions as multilateral deterrence asserts. Moreover, multilateral deterrence is mainly discussed in the context of nonproliferation. Under the framework of the Nonproliferation Treaty (NPT), for example, states are bound by and entangled in multilateral arrangements in order to prevent further proliferation. ${ }^{70}$ A multilateral arrangement may help prevent nuclear proliferation in certain cases but it is very unlikely that nuclear powers would allow themselves to be bound in advance by multilateral arrangements when devising and implementing their strategic policies vis-à-vis parties in a conflict where interests need to be pursued in a rapidly changing security environment.

\footnotetext{
${ }^{67}$ Goodpaster, A. J.et al. (1997). Post-Cold War Conflict Studies. Naval Studies Board National Research Council Washington D.C.: National Academy Press, p. 32.

${ }^{68}$ Ibid.

${ }^{69}$ ABM was the Anti-Ballistic-Missile Treaty. It was signed between the Soviet Union and the USA in 1972. It limited the number of anti-ballistic missile systems deployed in protecting fields against nuclear weapons delivered by missiles. In 2002, the USA withdrew unilaterally from the treaty arguing that the treaty is not relevant anymore to protect against the contemporary threats such as coming from Iran.

${ }^{70}$ Council on Foreign Relations (2013). The Global Nuclear Nonproliferation Regime Issue Brief, 25 June 2013 , [online] Available at:

http://www.cfr.org/nonproliferation-arms-control-and-disarmament/global-nuclear-nonproliferation-regime/p18984

[Accessed 28.03.2017].
} 


\subsubsection{Collective Actor Deterrence}

Morgan defines the collective actor as a group of states formed to protect general welfare, as opposed to pursuing only member interests. Morgan mentions that the states constituting collective actors can use deterrence to maintain peace and security for an international system. ${ }^{71}$

Both my argument and collective actor deterrence theory concerns the interaction of more than one actor in deterring a crisis. My argument, however, mainly differs from collective actor deterrence in the level of interaction. In collective actor deterrence, the level of interaction is very high, which leads to a complete cooperation. Below, I will explain some basic differences of collective actor deterrence and my argument. For example, Morgan explains that:

"Inside any collective actor is a smaller group that dominates the decision-making and any action taken. This shift in influence is not fully beneficial or acceptable to most states. It can increase the chances that something will be done but shrink their ability to determine what that "something" is. But it enhances the likelihood of coherent decisions and forceful threats, as well as their being upheld. Multilateralism is often made effective by a core "minilateralism"a small group that acts and lets the others just tag long. This leaves far fewer members needed to get threats and actions mounted for the sake of deterrence. ",72

The features of collective actor deterrence mentioned above resemble the characteristics of multilateral deterrence. In my argument, states are not bound to following the leadership of one or two major states. States collaborate to ease the crisis, but the level of cooperation among them is not high. Most importantly, states maintain their complete sovereignty and the freedom of action as they collaborate. There is no submissiveness or a hierarchy between major states mediating to crisis. In other words, in collective actor deterrence, there are strong states, which form a nucleus. Other states circle around strong states. In my argument, major powers collaborate but do not need to follow or circle around one state.

Morgan strongly emphasized the level of cooperation between the states constituting collective actor deterrence, to the extent that he even compared it with international law. He stated:

"Collective actor's deterrence these days is an extension of, and a tool in upholding, an emerging version of international law and order and the continuing development of norms - transnational, international and domestic- of proper behavior. "73

The increasing geopolitical struggles among major powers nowadays show that the level of cooperation among them cannot be interpreted as international law or order, as collective actor deterrence does. I propose that the major states collaborate in a vital area in which they share the same interests, namely the prevention of a nuclear catastrophe. In my model, the motivation to

\footnotetext{
${ }^{71}$ Morgan, P.M. (2003). Deterrence Now. the UK: Cambridge University Press, p. 172.

${ }^{72}$ Ibid. p. 182.

${ }^{73}$ Morgan, P.M. (2012). The State of Deterrence in International Politics Today. Contemporary Security Policy, Vol 33, Issue 1, 13 April 2012, p. 94.
} 
collaborate is not an attempt at building norms at an international level or building international structure. Motivation to collaborate emerged from a necessity of preventing a catastrophe. Mediator states can be in competition with each other in other fields. When it comes to preventing a nuclear catastrophe, however, they collaborate.

In collective actor deterrence, the implementation of threats is based on wide consensus among the members. The lack of consensus causes the credibility problem. ${ }^{74}$ However, Morgan asserts that building this consensus is not an easy task:

"Compared with national actors, the collective actor has an additional level of political consensus to establish. Some members will want no action taken or no actions as potentially costly as fighting, or will want more evidence that such a drastic step is really required, or will fear that getting confrontational may exacerbate the situation. "75

I argue that a mediator state does not have to act concomitantly with other states. If one mediator state acts, other major states have the option of collaborating with the mediator state or staying aside but not hindering the mediation attempt of the mediator state. They can actively collaborate or passively agree with the mediation effort of the mediator state.

Moreover, Morgan assumes that ensuring credibility sometimes requires building a cohesive military force, which compels states constituting collective actor deterrence to give up some of their authority. ${ }^{76}$ In that context, he used NATO as an example to demonstrate the high level of institutionalization needed between the members of collective actor deterrence. ${ }^{77}$ In my argument, there is no combined armed forces of collaborative mediation. I am referring to the collaboration of states, which have their separate armed forces. It is not possible to gather these separate armed forces under one roof because collaboration occurs only ad hoc during only vital phases of a nuclear crisis.

Morgan says that only liberal democratic states can organize themselves as collective actors, acting together for common welfare. ${ }^{78}$ However, in my model, it is not liberal democratic principles, but rather the danger of nuclear catastrophe, which compels states to collaborate regardless of whether the collaborating states share liberal democratic values or not. My argument differs from Morgan in the sense that collaborating states do not have to share the same values.

Collective actor deterrence would expect that the US, Russia, and China would not be able to cooperate because they do not necessarily share the same liberal values and they have competing

\footnotetext{
${ }^{74}$ Morgan, P.M. (2003). Deterrence Now, p. 185.

${ }^{75}$ Morgan, P.M. (2003). Deterrence Now, p. 183.

${ }^{76}$ Morgan, P.M. (2003). Deterrence Now, 185.

${ }^{77}$ Ibid. p. 177.

${ }^{78}$ Ibid. p. 174.
} 
interests. In my argument, however, they would collaborate because of the fundamental common interest of preventing a nuclear catastrophe.

In short, I argue that that a deterrence effect not only originates from conflicting parties. I argue that deterrence may occur at the international level, which limits conflicts with a nuclear dimension. I conceptualize this situation as double deterrence. I postulate that deterrence at the international level is a collaborative mediation of more than one state. This collaborative mediation is based on ad hoc arrangements; not on high-level cooperation, as collective actor deterrence asserts. Below is my hypothesis and the more detailed analysis of my argument.

\subsection{Hypothesis}

Crisis with a nuclear dimension transforms international mediation from competitive to collaborative. The collaborative international mediation then puts extra pressure on both sides of the conflict in addition to the direct deterrence between them. This helps keep the conflicts with a nuclear dimension stay in limited level.

Now I will explain the various parts of my hypothesis.

\section{A crisis with a nuclear dimension (at least one part of the conflict has nuclear capability) triggers the attention of the major powers (WHY?)}

A crisis with a nuclear dimension triggers the involvement of major powers because nuclear weapons have devastating effects not only for the countries which are in a crisis, but also for the entire world. For example, a nuclear crisis in South Asia between India and Pakistan does not carry grave consequences only for Russia or China (because of the geographic proximity), but also for the US. A triggered nuclear weapon would not only weaken the Non-Proliferation Treaty (NPT), but also deteriorate the nuclear taboo regarding the non-use of nuclear weapons after the Second World War. All of these developments would carry serious consequences for the US, the main architect of the international security system which emerged after the Second World War. The world has not yet experienced a nuclear war between two nuclear states. Even moving to this unknown situation, therefore, can persuade states to take incentives to prevent a war with nuclear dimension. 


\section{The situation described above transforms international mediation from interest-based self-oriented competitive mediation to a collaborative mediation. (WHY?)}

Because of the devastating effects of nuclear weapons for the entire world, major powers share the same interest in preventing a nuclear catastrophe. For this reason, they collaborate to prevent conflicts that involve a nuclear dimension.

By competitive mediation, I mean that in most mediation attempts the mediating states try to profit from the crisis and of the mediation process for themselves. ${ }^{79}$ Resolving the crisis is not a priority. Instead, the priority is to profit from the crisis or attempt to prevent other mediator states from seeking gains from the crisis. One can argue that there is a competition between mediator states in their mediation attempts.

By collaborative mediation, I refer to the collaborative behavior of the mediator states, which even includes inactivity on the part of influential states. - since this, in certain contexts, could mean the omission of disruptive policies against mediation.- Mediator states do not calculate how they can profit from the crisis during the mediation process, and their priority is to end the crisis.

\section{Collaborative International Mediation reduces the alignment options of the Sides of the} Conflict. (WHY?)

In most mediation attempts, mediator states use a combination of threats and/or encouragements to settle the crisis. For example, major states may threaten both parties of the conflict to retreat from the conflict. Mediator states may also strategically collaborate with each other. This collaboration prevents parties of the conflict from aligning with one mediator state against the other mediators. In other words, the sides of the conflict cannot play the mediator states against each other due to the collaboration among the mediator states. This situation limits the maneuvering capability of the sides of the conflict. This situation then

1. puts extra pressure on parties of the conflict in addition to the direct deterrence between each other, limiting the scale of the conflict.

\section{OR}

\footnotetext{
${ }^{79}$ As Bercovitch and Jackson argues mediators bring with them consciously or otherwise, ideas, knowledge, resources and interests, of their own or of the group they represent. Mediators often have their own assumptions and agendas about the conflict in question. Bercovitch, J. \& Jackson, R. (2009). Conflict Resolution in the Twenty-first Century: Principles, Methods, and Approaches. The US: The University of Michigan Press, p. 33.
} 
2. encourages the parties of the conflict to back down without losing face. Major powers collaborate and provide incentives to end the crisis. Parties of the conflict can then use these incentives to retreat without losing credibility.

This also helps limit the scale of the conflict. (OUTCOME)

Below, I depicted my hypothesis with a flow chart.

Scope Condition: Nuclear Dimension of the Conflict

At least one side of the conflict has nuclear capabilities.

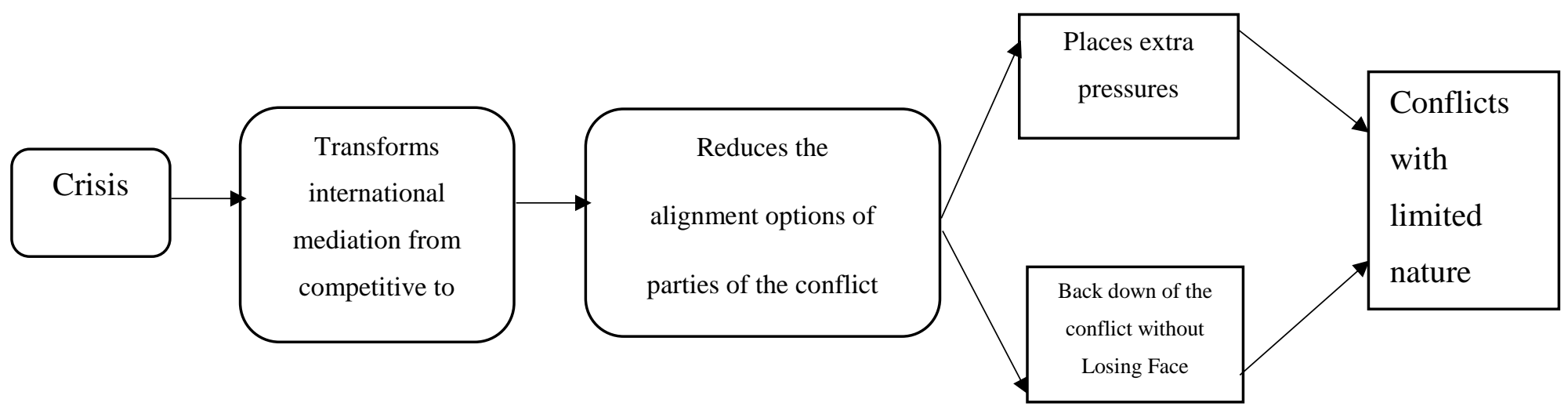

\subsection{Variables}

Independent Variable: A crisis with nuclear dimension.

Dependent Variable: Conflicts with limited nature.

Intervening Variable: Transformed international mediation and its impacts on the sides of the conflict.

Scope Condition: At least one side of the conflict has a nuclear capability.

\subsection{Research Questions}

- Does a crisis with nuclear dimension have impacts on the relationships between major nuclear states?

- Can a crisis with nuclear dimension cause changes in the mediating patterns of major nuclear states? 
- Does this changed relationship pose pressure and form a second deterrence other than the threat that parties of the conflict pose to each other?

- Can this changed behavioral pattern help limit the scale of conflict?

\subsection{RESEARCH DESIGN}

I use in-depth case study analysis as the main methodology for this research, using the crises between India and Pakistan from 1947 until present day.

\subsubsection{Case Selection}

I focus on the crises between India and Pakistan because they are both countries with nuclear weapons that have not signed the NPT. I therefore would like to test my hypothesis in a geographic region where both parties of the conflict are relatively flexible in their nuclear decisions. Furthermore, they have pursued conflicting foreign policies since independence. There is a high possibility that any dispute can escalate to a nuclear level in this region. It is therefore additional aim of this study to test the impact of collaborative international mediation in this conflicting context. There are actually few possible cases in which I can apply my hypothesis, which are listed below.

\subsubsection{The Dyadic Crises as Other Possible Cases}

- North Korea - South Korea nuclear crises. (It is difficult to acquire data on North Korea.)

- The US and Soviet Union/ Russia or China. (They are major powers. It is not conceivable that pressure appearing at the international level would ease the crises between them.)

- Israel and Arab countries. (Israel neither accepts nor denies its nuclear capability.)

- India and China crises. (This case is a complementary to my case study)

The crises between India and Pakistan is the only case which received significant international mediation. Therefore, it is possible to observe international mediation throughout the years from independence until present day. Due to these reasons, the crises between India and Pakistan is arguably best suited for this analysis.

Below are the major crises between India and Pakistan.

- 1947 India and Pakistan War, 
- 1965 Runn of Kutch Crisis

- India - Pakistan War of 1965,

- 1971 India and Pakistan War and the Independence of Bangladesh,

- 1974 Indian Nuclear Tests

- 1984 Kahuta Crisis,

- 1987 Brasstacks Crisis,

- 1990 Kashmir Crisis,

- 1999 Kargil Crisis,

- 2001 India Parliament Attack,

- 2008 Mumbai Attacks.

Each of the crises above are subcases of one case. I gathered these subcases into two main groups: the first is the nonnuclear phase from 1947 until the Indian nuclear testing incident in 1974. The second phase is the nuclear phase which started in 1974 and continues until present day. Using historical analysis as a method, I compared the nuclear and nonnuclear phases in order to understand whether there was a change in the pattern of international mediation. I then follow the process during the nuclear phase to identify the parts of the hypothesis that I proposed. By following the process, I sought to demonstrate whether/how the crisis transformed international mediation from a competitive to collaborative one in the nuclear phase. Subsequently, I show whether/how this transformed international mediation limited the scope of the wars.

For each crisis, I begin the analysis with US mediation, using declassified documents from the US Department of State Office of the Historian. The declassified documents used for this analysis are:

- Memorandums

- Telegrams and messages from US embassies to the US Department of State and from the US Department of State to US embassies,

- Minutes of the National Security Council meetings,

- Letters from US presidents to the presidents of Pakistan and India,

- Transcripts of telephone conversations.

These documents were once classified as top secret documents. After a certain amount of time, they were released to public under the Freedom of Information Act. However, documents for 
the crises occurring after 1990 are not yet available, as the US Department of State Office of the Historian has not declassified most of the relevant documents. Thus, for this period of time I have analyzed the hearings held in the US Senate and in the US House of Representatives as primary data. Hearings are important indicators in the US context because the Congress is a legislative body controlling - and in some circumstances limiting - the actions of the US administration. As such, discussions by the Congress are important indicators of US foreign policy. Using data from congressional hearings and secondary resources helped reveal US considerations when mediating crisis and conflict between India and Pakistan. In addition, I used memoires, diaries, and interviews done by journalists. These diaries and memoires are important indicators because they were written by officials who directly participated in the US mediation efforts in South Asia.

In analyzing the Soviet Union's mediation style, I collected primary data from an archival study by Rajendra Kumar Jain. Jain collected primary documents for the period 1947 - 1978 pertaining to Soviet and South Asian relations. To analyze Russian mediation after 1990, I searched for speeches, transcripts, and documents released on the official websites of the President of Russia and the Ministry of Foreign Affairs of Russia. I also searched the archives of the Wilson Center Digital Archive International History Declassified in order to find Russian attitudes regarding the crises in South Asia. Additionally, I analyzed secondary resources on the Soviet Union and then later, Russia’s role in South Asia.

I used the articles released by the Peking Review in order to analyze Chinese mediation. Peking Review is the only official Chinese news magazine published in English, and most issues are made available online by Marxist Internet Archive. Peking Review was later renamed as the Beijing Review. I have also analyzed news from the Xinhua News Agency. It is the official press agency of the People's Republic of China. The president is also a member of the Central Committee of the Communist Party of China. Therefore, in identifying Chinese foreign policy, news released by Xinhua News Agency can be considered as important indicators. By using the database NEXIS, I systematically reached most of the articles released by Xinhua News Agency throughout the years. Additionally, I also analyzed secondary resources and working papers regarding China's role in South Asia. I used the archives of Wilson Center Digital Archive International History Declassified as well. 


\subsubsection{Evaluation of the Data}

In evaluating the data, I used the same method of Rublee presented in her book Nonproliferation Norms. Rublee analyzed the reasons some states opt not to seek nuclear weapons, even if they have the technical capability. ${ }^{80}$ This provided a suitable framework for analyzing nuclear proliferation. In my study, I classified crises into two main groups: nonnuclear and nuclear. For both groups, I first identified expectations against which to compare and measure what really occurred. I named these occurrences as observations. By expectation, I mean what the relevant behavior of the mediator states should be, given that my hypothesis is correct. For each expectation, I also generated assumed policy actions of mediating states and policy discussions that might be held in the decision-making bodies of these states. I then analyzed the data and compared whether my expectations are fulfilled, and to which degree. When I analyzed a piece of evidence, I also considered the context. Accordingly, it increased or decreased the confidence that $\mathrm{I}$ have in each piece of evidence that I collected. Next, I briefly discussed other factors which have an influence on the interpretation of the evidence. Below is the criteria that I used in the evaluation of data.

\subsubsection{Criteria in Analyzing the Data}

\subsubsection{First Group of Cases: Nonnuclear Phase}

In the first group, neither parties of the conflict have nuclear capabilities. Below are my expectations and associated actions and discussions.

\subsection{Expectation 1}

No nuclear dimension and the presence of competitive behavior. (Instead of collaborative behavior).

Expected Actions: The prime interest of mediating states is not to resolve the crisis. Instead, the countries compete with each other to seek gains from the crisis or they try to hinder potential gains of other mediator states. While they may want to settle the crisis, they do so in a way that best addresses their own interests. Mediator states may also frequently blame other mediator states for the instigation of the conflict. Therefore, there is a certain level of competition and conflictive language among the mediator states.

Expected Discussions: I expect that decision-making bodies of mediator states will focus on how their action or inaction to the crisis will impact other potential mediator states. The questions that follow are: If we do not actively mediate, will the inaction benefit other mediator

\footnotetext{
${ }^{80}$ Rublee, M.R. (2009). Nonproliferation Norms: Why States Choose Nuclear Restraint. Athens, Georgia: The University of Georgia Press. pp. 21-28.
} 
states? Alternatively, if we mediate, could it prevent other mediating states from gaining greater regional influence?

\subsection{Expectation 2}

Competitive mediation reduces the effectiveness of pressure for both parties of the conflict.

Expected Actions: Mediator states do not collaboratively place pressure on parties of the conflict to end the crisis. Each mediator state supports the state with which it has good relations. There is no coordination between mediator states, which will relieve parties of conflict from the pressures of international mediation.

Expected Discussion: I expect that the discussion will focus on the possible consequences of supporting or not supporting parties of the conflict with which the mediator state has a good relationship. These questions on the decision-making body may follow: If we do not mediate in support of the state with which we have a good relationship, will this state seek support from another mediating state? Alternatively, if we support the state that has a good relationship with another mediating state, will it cause a rift between this state and another mediating state? How could it profit our state? As noted below, these considerations relieve both parties of the conflict from pressures of international mediation.

\subsection{Expectation 3}

The sides of the conflict have more maneuver capability to choose different foreign policy (alignment) options.

Expected Actions: If the mediator state does not give enough support to the party of the conflict with which it has a better relationship, then this state may move between other mediator states in search for support.

Expected Discussion: High-level politicians of both sides of the conflict will express their changed position (or threat to change their position) if the support does not come from the mediator state with which it has good relations.

\subsubsection{Second Group of Cases: Nuclear Phase}

\subsection{Expectation 4}

The nuclear dimension of the conflict leads to collaborative behavior among mediator states.

Expected Actions: Mediator states try to settle the crisis as its first goal. Even if these states have alternative interests, these differences do not lead to competition because their main agenda is to prevent a nuclear catastrophe. The priority is to resolve the crisis. Mediator states 
collaborate with each other, or they at least welcome the mediation attempts of other mediator states and do not try to hinder them.

Expected Discussion: I expect that the discussion among the decision-making bodies of mediator states will focus on how to best hinder the conflict: The decision makers of the mediator states may ask the following questions: what threats or incentives should be made in order to hinder the conflict, and what kind of dialogue should be pursued with other mediator states for collaboration?

\subsection{Expectation 5}

Collaborative mediation places pressure on the sides of the conflict effective.

Expected Actions: There will be a certain level of coordination and communication between mediator states. If a mediator state rejects the alignment attempt of one side of the conflict, then other mediator states will also reject the alignment attempts of the parties to the conflict. Therefore, both parties cannot play the mediator states against each other. This will reduce the maneuvering capability of the parties of conflict and will strengthen the pressure from international mediation.

Expected Discussion: The mediator states would try to find ways to facilitate a direct dialogue between the parties of the conflict. If direct dialogue were not possible due to high tension between the parties of the conflict, the mediator states would then consider offering their services or emissaries to enable this dialogue. Discussions will focus on whether a mediator state should send a highly respected diplomat to the region, or whether a joint commission should be established with other mediator states to facilitate a direct dialogue between both sides of the conflict.

\subsection{Expectation 6}

Both parties of the conflict may use international mediation as a tool to withdraw from the conflict without losing face.

It would be difficult resist international mediation based on a large collaboration. Withdrawing from the conflict would therefore be tolerable and more understandable for the citizens of the rival countries. This perception can hinder the opposition forces in the respective countries from seeking political gains. It thus supports the government's decisions of withdrawing from the conflict without serious domestic political risks.

Expected Actions: High-level politicians of sides of the conflict may publicly support international mediation. They can praise international mediation for its role in solving the crisis. They may overtly attribute the settlement of the crisis to international mediation. 
Expected Discussions: Mediator states will discuss how to proceed with mediation or emissaries. They may consider new ways to consolidate the dialogue between both sides of the conflict. They can also create more confidence building measures.

Even if I can demonstrate that major powers collaborate with each other - once the crises between India and Pakistan took on a nuclear dimension - I must still consider the effect of the end of the Cold War. One can argue that major powers became collaborative because of the Cold War ended, not because of the nuclear dimension of the Indian - Pakistani conflict. I have two strategies to deal with this problem.

1- ) I will analyze the 1984 Kahuta Crisis and 1987 Brasstacks Crisis which occured between India and Pakistan. If I find a pattern of collaborative mediation in these crises, although these crises occurred during the Cold War, it would strengthen my argument.

2- ) I will also analyze the geopolitical rivalry between the US, Russia, and China in our contemporary world. I will focus briefly on the struggle between the US, and China in the South China Sea regarding the Spratly Islands. China demands complete sea navigation rights in the South China Sea which caused problems with the Philippines, Malaysia, Vietnam, and Taiwan. It also tried to hinder the navigation rights of the US navy in the South China Sea. I will also briefly mention the recent crises between Russia and the West. Subsequently, I will be able to demonstrate that even if the Cold War is over, it does not automatically translate into collaborative relationships. In other parts of the world, the US, Russia, and China continue to compete.

I will touch on these topics in a small chapter, but not as a comprehensive case study.

I analyzed the crises between India and China. My analysis of the crises between India and China complements the main case study of the present work. The aim is to identify and examine whether there is an identical mediation pattern in both India - China and India - Pakistan crises. I chose to analyze this case because India and China are two states, with territorial conflicts experienced since their independence. The crises between India and China also gained a nuclear dimension when China demonstrated its nuclear capability in 1964. This also carried significant implications beyond the region. 


\section{METHODOLOGY}

In each subcase, I first present an overview of the crisis. Next, I proceed with the mediation strategy of the US. Afterwards, I continue with the Soviet and Russian mediation strategy, and analyze China last. Subsequently, I discuss the actions of mediator states in each crisis, and summarize the main characteristics of their mediation attempts in that particular crisis in one paragraph. For example, after explaining the US mediation strategy of the 1965 crisis, I wrote a paragraph at the end of the section defining the main characteristics of US mediation during the crisis. I approach the Soviet, Russian and Chinese mediation strategies in the same systematic way as I do for the US. Using this systematic approach makes the comparison easier. Finally, I compare their main characteristics in their mediation attempts in two phases. I compare whether these mediation patterns meet the expectations that I laid out in the introduction section.

\subsection{First Group of Cases: Non-nuclear Phase}

\subsubsection{India - Pakistan War of 1947}

\subsubsection{Overview}

The India and Pakistan conflict has its roots going back to the partition of British India. The All-India Muslim League and Indian National Congress were leading parties during the struggle against the British rule. These two parties had competing ideas regarding post- independence India. The National Congress Party, led by Mahatma Gandhi and Jawaharlal Nehru, were supporting the ideal of a secular India in which different cultures, religious, and ethnic groups live together. In contrast, the Muslim League led by Muhammad Ali Jinnah was struggling for a separate Muslim state. This division was better for British interests than a united Indian nationalism during the period under British rule. ${ }^{81}$

At the time of the British departure, there were 565 princely states which had privileges under the rule of British India. After the partition of British India, they had to decide whether they should join Pakistan or India. They also had the possibility of preserving their independence, which would however be difficult given that most princely states were not self-sufficient. At the time, they were geographically dependent on either India or Pakistan. ${ }^{82}$ These princely states became a subject of intense ideological competition between India and Pakistan.

Out of the 565 princely states, Jammu and Kashmir had some unique characteristics which made the competition between joining India or Pakistan fierce. It had a Hindu ruler, the Maharaja,

\footnotetext{
${ }^{81}$ Ganguly, S.(1994). The Origins of War in South Asia: Indo - Pakistani Conflicts Since 1947. Colorado: the US and Oxford: the UK: Westview Press, Inc., p. 14.

${ }^{82}$ Schofield, V. (2003). Kashmir in Conflict: India, Pakistan and the Unending War. London and New York: I.B. Tauris \& Co Ltd., p. 24.
} 
but the majority of its population was Muslim. There were also Buddhists living in Ladakh. It was geographically contiguous to both India and Pakistan. ${ }^{83}$ Joining Pakistan would make the Hindus of Jammu and the Buddhists of the Ladakh minority in Pakistan. Joining India would also put the Maharaja Hari Singh in a difficult position because the majority of the state was Muslim. ${ }^{84}$ Moreover, Hari Singh was not keen on joining India because of Nehru's close ties to Sheikh Abdullah, who was a major dissident figure in Jammu and Kashmir. ${ }^{85}$ The State of Jammu Kashmir was vital for both India and Pakistan. Joining India would prove the position of the National Congress that a predominantly Muslim state could live under the rule of a secular India. It would however be a direct challenge to the founding ideology of Pakistan, which claims to be a state for all Muslims in India. Therefore, Maharaja's delay in reaching a decision caused frustrations in both India and Pakistan. The discontent among Muslim populations were also rising and it finally culminated on July 1947 in the district of Poonch, where Maharaja faced recurring problems with the local Muslim population.

Most of the population in Poonch were experienced soldiers who fought in the Second World War in the Indian Army. Intense taxation and the dissatisfaction of soldiers with their lives were the main causes of the uprising. ${ }^{86}$ Rebels in Poonch sought to buy weapons from the arms bazaars in the North-West Frontier Province (NWFP) of Pakistan. ${ }^{87}$ This is important because these purchases built the bases for further relations with the tribal forces living in NWFP, which later infiltrated into Jammu \& Kashmir to fight against the Maharaja. By August 1947, the revolt reached its peak. Its leaders established the Azad (Free) Kashmir and became an autonomous region of Pakistan. ${ }^{88}$ Pakistan also helped the rebels in Poonch by creating an economic blockade. At the time, the state of Jammu\& Kashmir was dependent on imports from Pakistan. As such, the economic blockade weakened the economy of the State and prevented it from launching a conclusive struggle against the uprising. ${ }^{89}$

On 22 October 1947, the struggle against the Maharaja gained momentum. The Pathan tribesmen crossed the border to support the uprising in Poonch. They defeated the state forces of

\footnotetext{
${ }^{83}$ Ibid. p. 28.

${ }^{84}$ Singh, Karan (1982). Heir Apparent Oxford: Oxford University Press, p. 53.

${ }^{85}$ Ibid. p. 41.

${ }^{86}$ Brines, R. (1968). The Indo-Pakistani Conflict. London: Pall Mall Press Ltd., p. 69.

${ }^{87}$ This region is now named as Khyber Pakhtunkwa.

${ }^{88}$ Brines, R. (1968). The Indo-Pakistani Conflict, p. 69.

${ }^{89}$ Prasad, S.N. and Pal, D. (1987). Operations in Jammu \& Kashmir 1947-48. New Delhi: Controller of Publications, Ministry of Defence History Division Government of India printed by Thomson Press (India) Ltd. Thomson Press (India) Limited, pp. 14-15.
} 
Jammu \& Kashmir and captured Muzaffarabad and Domel. Tribal forces also captured Uri and Baramula after a firm resistance. The way to the capital, Srinagar, was open. ${ }^{90}$

On 31 October 1947, the Maharaja experienced another challenge to his rule, this time in Gilgit. The paramilitary forces in Gilgit, Gilgit Scouts, were mainly Muslim and they opted for joining with Pakistan. They rebelled against the representative of Maharaja, Brigadier Gansara Singh, and took over the control. They occupied Baltistan and declared their inclusion to Pakistan. This development gave Pakistan control in northern Kashmir. ${ }^{91}$ Gilgit Scouts was very effective. They invaded the district of Sakardu, and launched a military offensive from Sakardu to Leh, which is the capital of Ladakh. They also invaded Kargil. ${ }^{92}$

Under these circumstances, the Maharaja Hari Singh made a plea to India for assistance. India accepted to help only on the condition that Maharaja signed an Instrument of Accession to India. The situation seemed desperate to Hari Singh and he was therefore forced to accept India's terms. He signed the Instrument of Accession on 26 October 1947; just four days after the tribal invasion had started. One day later, on 27 October, India immediately sent troops and equipment to Srinagar to help Maharaja. ${ }^{93}$

After Jinnah heard of the Indian participation in the conflict, he immediately urged the acting Commander-in-Chief of the Pakistani Army General Douglas Gracey to send in his own troops. The challenge for Jinnah was that India and Pakistan was under the same supreme command at that time. The Army Supreme Commander Auchinleck resisted a possible inter-Dominion war and threatened Jinnah by the resignation of all British officers in case of a Pakistani offensive. Jinnah could not have resisted at this point because the resignation of all British soldiers would have weakened the Pakistani army. $^{94}$

Indian forces were successful at the beginning of the conflict and managed to halt the advance of the Pakistani supported tribesmen. The defeated tribal forces were chased to Baramulla and Uri. Kargil, Baramulla, and Uri were recaptured in the end. In the Poonch Valley, however, tribal forces continued to besiege state forces. ${ }^{95}$ The subsequent attempts to recapture the whole of Poonch failed. ${ }^{96}$ Despite

\footnotetext{
${ }^{90}$ Prasad, S.N. and Pal, D. (1987). History of Operations in Jammu \& Kashmir (1947-48) New Delhi: Controller of Publications, Ministry of Defence History Division Government of India printed by Thomson Press (India) Ltd. pp. 2627.

${ }^{91}$ Brines, R. (1968). The Indo-Pakistani Conflict, p. 69.

${ }^{92}$ Lamb, A. (1966). Crisis in Kashmir 1947 to 1966. Routledge \& Kegan Paul, London. p. 53. and Schofield, V. (2003). Kashmir in Conflict: India, Pakistan and the Unending War. London and New York: I.B. Tauris \& Co Ltd., p. 66.

${ }^{93}$ Lamb, A. (1966). Crisis in Kashmir, p. 45.

${ }^{94}$ Ibid. p. 49.

${ }^{95}$ Sarkar, B. (2016). Defense of Srinagar 1947 Indian Defense Review [online] Available at: http://www.indiandefencereview.com/interviews/defence-of-srinagar-1947/ [Accessed 27.03.2017].

${ }^{96}$ The district of Poonch was divided into two parts after the conflict. One part became a part of Pakistani controlled
} 
early successes, the Indian army suffered a setback in December 1947 because of logistical problems. ${ }^{97}$ The tribal forces began an offensive attack again and pushed back Indian troops from the border areas. In the spring of 1948, India mounted another offensive. Pakistan also officially became involved in the conflict in May 1948. The fighting continued from the spring through December 1948. Pakistani forces also conducted operations in both the northern and the southern regions of the State of Jammu \& Kashmir. ${ }^{98}$ The conflict eventually reached a dead end, and neither side was making promising progress. This deadlock paved way for mediation by the UN. India actually already appealed to the UN on 1 January 1948. The UN released the Resolution of 38 on 17 January $1948 .{ }^{99}$ However, the resolution was nothing more than a suggestion to India and Pakistan to take all measures to improve the current situation. Then, on 20 January 1948, the UN released the Resolution of 39. ${ }^{100}$ The Resolution 39 formed a commission to observe the crisis. Despite these resolutions, the fight continued during the spring of 1948. Only the deadlocks in the battlefield paved the way to further UN mediation. UN Resolution of 47 urged allowing the use of a plebiscite to allow the Kashmiri people to decide their future. ${ }^{101}$ On 20 January 1949, an agreement was reached on a Cease-fire Line along the positions held by the two armies at the end of the hostilities. The line is a de facto international border. ${ }^{102}$ However, the plebiscite was never held. Pakistan argued that Indian troops should be withdrawn before the plebiscite. India argues that it is impossible because of Pakistan's support to tribesmen and the local Muslim population in the State of Jammu \& Kashmir. At the end, one-third of the former princely state fell under Pakistani control, which is known as 'Azad' (Free) Jammu and Kashmir. India controls the two-thirds of the State, which is known as Jammu and Kashmir. Indian territory is composed of Ladakh, Jammu and the valley of Kashmir. Since 1949, the ceasefire line has been monitored by a small force of the United Nations Military Observer Group in India and Pakistan (UNMOGIP).

International reaction to the conflict was weak. The UN could have mediated the conflict because India had itself requested it. If India had not applied to the UN by its own decision, the conflict would not have been internationalized. Without the deadlock in the battlefield, it would have been difficult to imagine an effective UN mediation.

\footnotetext{
Azad Kashmir, the other part went to Indian controlled the State of Jammu and Kashmir.

${ }^{97}$ Ganguly, S. (1994). The Origins of War in South Asia, p. 13.

${ }^{98}$ Ibid. p. 14.

${ }^{99}$ The UN Resolution 38 (1948). Resolution of 17 January 1948 [S/651]. Resolutions Adopted and Decisions Taken By the Security Council in 1948 [online] Available at: http://unscr.com/en/resolutions/38 [Accessed 29.03.2017].

${ }^{100}$ The UN Resolution 39 (1948). Resolution of 20 January 1948 [S/654]. Resolutions Adopted and Decisions Taken By the Security Council in 1948 [online] Available at: http://unscr.com/en/resolutions/39 [Accessed 29.03.2017].

${ }^{101}$ The UN Resolution 47 (1948). Resolution of 21 April 1948 [S/726]. Resolutions Adopted and Decisions Taken By the Security Council in 1948 pp. 3-6. [online] Available at: http://unscr.com/en/resolutions/47 [Accessed 29.03.2017].

102 Brines, R. (1968). The Indo-Pakistani Conflict, p. 76.
} 
Britain showed an interest in the conflict because it might have partly felt responsible for the conflict because of the way of Britain divided India. Moreover, Britain wanted good relationships with both India and Pakistan after their complete independence. They were still dominions at the time of conflict. They also opted for staying in the Commonwealth. Therefore, the conflict between two Commonwealth states was of interest for Britain. Below, I analyze the position taken by the US, the Soviet Union and China during the conflict.

\subsubsection{The US Mediation}

The US interest in the 1947 crisis developed at the very onset of the conflict. On 28 October 1947, Charles William Lewis Jr., the then chargé d'affaires in Pakistan, sent a telegram to the US Secretary of State, demonstrating that the US was observing the incidents and was concerned that the Pakistani government was pressuring Kashmir to join Pakistan by means of economic strangulation. The telegram also revealed that the US was aware that Pakistan was sending soldiers and tribesmen from the northwest frontier into Kashmir. ${ }^{103}$

The US believed that the atrocities between India and Pakistan were difficult to mitigate without external mediation. Despite the close monitoring of events, the US lacked the necessary knowledge and experience regarding the region's particularities to provide needed external mediation. The US, therefore, relied on the British network and knowledge in the region though it also had hesitations regarding the British ability to mediate. The telegram sent by the US Embassy in India to the US Secretary of State on 3 November 1947 expresses this concern. The US Ambassador Henry F. Grady reported that he met with Sir Girja Shankar Bajpai, the Secretary General of the Ministry of External Affairs of India. Bajpai told Ambassador Grady that Nehru had sent a wire to British Prime Minister Clement Atlee, and urged him to demand that Pakistan use its influence on tribesmen to withdraw from the conflict. Atlee, however, only made a recommendation to both sides that peace should be preserved. Bajpai told US Ambassador Grady that the government of India felt that Atlee's message was patronizing and failed to appreciate the Indian position. Bajpai reported to Grady that Nehru replied to Atlee, and complained that Britain took India's friendship for granted. ${ }^{104}$ This was a serious setback for Britain, if the British wanted to be a broker between the conflicting parties.

Another telegram sent by the then Acting Secretary of State Robert A. Lovett to the US Embassy in India on 2 December 1947 also revealed US doubt regarding the UK's role in the crisis.

\footnotetext{
${ }^{103}$ Foreign Relations of the United States Office of the Historian (hereafter FRUS), 1947, The British Commonwealth; Europe, Volume III Telegram 845.00/10 - 2847 Sent by The Charge in Pakistan (Lewis) to the Secretary of State Karachi, 28 October 1947, pp. 179-180. [online] Available at: https://history.state.gov/historicaldocuments/frus1947v03/d119 [Accessed 27.03.2017].

${ }^{104}$ FRUS, 1947, The British Commonwealth; Europe, Volume III 845.00/11-347: Telegram The Ambassador in India (Grady) to the Secretary of State, 3 November 1947, [online] Available at:

https://history.state.gov/historicaldocuments/frus1947v03/d120\#fn:1.3.2.2.10.5.5.8.18 [Accessed 26/03/2017].
} 
"It is increasingly apparent that this major difficulty between India and Pakistan probably cannot be removed without external assistance, or without resort to further armed conflict which may eventually involve some or all of the Afghan border tribes. Despite their vested interests in this area, because of the peculiarities of their position and the recentness of their withdrawal, the British are apparently not in a position to render this outside assistance. "105

Despite this hesitation, the US continued to coordinate its efforts with the British. In the same telegram, Lovett said that although the US would prefer direct negotiations between India and Pakistan to settle the conflict, the US would support the UN resolution if the United Kingdom did so as well. After it had become clear that the conflict would be resolved by the UN resolution, Lovett sent another telegram to the US Embassy in India on 31 December 1947, ordering the conveyance of a message to Nehru. In this message, it was stated that:

"The US as a firm friend of both India and Pakistan regrets that they have been unable by direct negotiation to solve the Kashmir problem. It now appears that the UNSC (United Nations Security Council) will soon be seized of this issue. US Government will respond fully to its obligations as a member of SC to assist in the attainment of an early and peaceful settlement."

An analysis of primary documents revealed that the US interest in the conflict was pursued mostly by means of monitoring. US embassies in the region only reported the developments of the crisis, and did not proactively engage the region to end the conflict. ${ }^{107}$ Firm contact was established with the UK, although they were some concerns as to the capability of the British mediators. In the end, the US supported the UN resolution.

This is a case where no belligerent language by the US can be observed regarding the mediation of the Soviet Union.

\subsubsection{The Soviet Mediation}

South Asia lies geographically close to the Soviet Union, thereby peaking interest by the Soviet Union in the region's political developments. This interest translated to monitoring the crises in the 1940s, but never transformed into direct mediation. The Soviets were instead preoccupied with consolidating their European borders. Therefore, in this section, instead of analyzing the Soviet mediation to the 1947 war in particular, I will examine the general Soviet attitude to Kashmir crisis in 1950s. Although the Soviet Union was not directly involved in the region in the 1940s, India's

\footnotetext{
${ }^{105}$ FRUS (1947, Volume III, The British Commonwealth; Europe). The Telegram from The Acting Secretary of State to the Embassy in India. 2 December 1947, 501.BB/12-247: Telegram [online] Available at:

https://history.state.gov/historicaldocuments/frus1947v03/d121\#fnref:1.3.2.2.10.5.6.7.4 [Accessed 27.03.2017].

${ }^{106}$ FRUS, 1947, The British Commonwealth; Europe, Volume III, Telegram 745.45F/12-2947 Telegram Sent by the Acting Secretary of State to the Embassy in India, 31 December 1947, pp. 192- 193. [online] Available at: https://history.state.gov/historicaldocuments/frus1947v03/pg_192 [Accessed 27.03.2017].

${ }_{107}$ The documents revealing the US observance of Kashmir dispute in 1947 can be reached from FRUS 1947, The British Commonwealth; Europe, Volume III [online] Available at:

https://history.state.gov/historicaldocuments/frus1947v03/ch4subch2 [Accessed 27.03.2017].
} 
perception was different. For example, Asaf Ali, the Indian ambassador to the US, once communicated the Soviet interest in the region to the US Acting Secretary of State Robert A. Lovett, and compared it with Japanese aggressions in 1941-42. ${ }^{108}$

In the 1950s, strong ties between Pakistan and the US were a major problem for the Soviet Union. India, on the other hand, declared its position to pursue a foreign policy independent of both the West and the communist bloc. Indian Prime Minister Nehru did not want to be associated with neither of these two dominant powers. Tangible relations developed after Nikita Khrushchev became the First Secretary of the Central Committee of the Communist Party. On 8 August 1953 in a public statement, the Chairman of the Council of Ministers Georgy Malenkow signaled a policy change towards India by recognizing India's efforts in ending the war in Korea. ${ }^{109}$

In February of 1955, large-scale economic assistance was given to India. The fundamental point was the visit of Nehru to the Soviet Union in June 1955. Nehru received a warm welcome, and the Soviet Union even agreed to construct what became the Bhilai steel plant. ${ }^{110}$ In the same year, Khrushchev and the premier of the Soviet Union Nikolai Bulganin visited India. On 10 December 1955, Khrushchev stated in Srinagar that:

"The people of Jammu and Kashmir want to work for the well-being of their beloved country-the Republic of India. The people of Kashmir do not want to become toys in the hands of the imperialistic Powers. But this is exactly what some Powers are trying to do under the pretext of supporting Pakistan with regard to the Kashmir Question... ",111

At a press conference in New Delhi on 14 December 1955, Khrushchev and Bulganin reiterated their support for Kashmir as an integral part of India. ${ }^{112}$ Addressing the Supreme Soviet from 26 to 29 December 1955, Bulganin stated that "the Kashmir problem was the creation of powers pursuing military and political objectives in that area. The people of Kashmir have come out against this imperialistic policy.",113

\footnotetext{
${ }^{108}$ FRUS Memorandum of Conversation, by the Acting Secretary of State 845.00/10-747, 7 October 1947 [online] Available at: https://history.state.gov/historicaldocuments/frus1947v03/pg_167 [Accessed 27.03.2017].

109 Dixit, A. (1990). India, Pakistan and the Great Powers in Jasjit Singh (ed.) (1990) India and Pakistan: Crisis of Relationship. New Delhi: Lancer Publishers Pvt. Ltd. in association with Institute for Defence Studies and Analysis, pp. 38-39.

${ }^{110}$ Mohanty, A. (2015). Six decades since Nehru's first official USSR visit. Russia \& India Report, 2 July 2015 [online] Available at: https://in.rbth.com/arts/2015/07/02/six_decades_since_nehrus_first_official_ussr_visit_44003 [Accessed 27.03.2017].

${ }^{111}$ Keesing's Contemporary Archives 1955-56, p. 14604 cited in Das Gupta, J.B. (1968) Jammu and Kashmir. The Hague: Martinus Nijhoff, p. 222.

${ }^{112}$ Asian Recorder (1955) Delhi, p. 562 cited in Das Gupta, J.B. (1968) Jammu and Kashmir. The Hague: Martinus Nijhoff, p. 222.

${ }^{113}$ Keesing's Contemporary Archives, 1955-56, 14654 cited in Das Gupta, J.B. (1968) Jammu and Kashmir, p. 222.
} 
Starting in the 1950s, the Soviet Union briefly supported the Indian position concerning the Kashmir problem and discredited the US and British efforts to solve Kashmir problem as imperialistic behavior.

\subsubsection{The China's Mediation}

China was not directly involved in the crises between India and Pakistan at this period. Only after the proclamation of the People's Republic of China by Mao Zedong in 1949 did China start to focus on the crises in South Asia. Therefore, I analyzed the statements of Chinese politicians during the 1950s in order to reveal the Chinese attitude towards the role of the Soviet Union and the US or the UN in the crises between India and Pakistan.

The main concern for China was that the crises between India and Pakistan was exposing the region to US influence. The Manila Pact and Baghdad Pact, the security organizations initiated by the US were particularly alarming to China. It considered the membership of Pakistan into these western-based security organizations as a direct threat to China's security in the region. One can identify this concern in declassified Chinese documents. For example, on 4 January 1956, the then Chinese Premier Zhou Enlai expressed China's discomfort with the then Pakistani Ambassador to China, Sultanuddin Ahmad as:

"The Manila Pact is governed by the United States. The Baghdad Pact is governed by Britain, and of course the United States is behind Britain. Pakistan is in a very awkward position in Asia after joining these two pacts; it is very disadvantageous to be controlled and pinned down like this by Western nations. "I14

Zhou Enlai also made the Chinese position clear, conveying that China was in favor of direct talks between India and Pakistan to resolve the crisis in Kashmir. He emphasized that one should give priority to the will of the Kashmiris and that other states should not use the Kashmir issue as an opportunity to start a war in the region. ${ }^{115}$

China was also concerned with the interventions of the UN. For example, in another meeting with the Pakistani ambassador on 16 February 1957, Zhou Enlai pointed out that there is a link between interventions by the UN and imperialist aspirations. He argued that the problems between India and Pakistan provide reason to the UN to intervene. This situation was argued to empower imperialist states. In the same meeting, he articulated that:

“...the two countries have put vast numbers of armed forces at the border. Imperialists will make use of the disagreements to instigate a conflict. Now the United Nations is once more getting involved; this is very dangerous.

\footnotetext{
114 Wilson Center Digital Archive International History Declassified. Abstract of Conversation between Chinese Premier Zhou Enlai and Pakistani Ambassador to China Sultanuddin Ahmad 04 January 1956 [online] Available at: http://digitalarchive.wilsoncenter.org/document/114840.pdf?v=bb8424ddee551a7d7de3ca1d9766604a [Accessed 27.03.2017].

115 Ibid.
} 
Nothing good comes from United Nations involvement; thus, we are worried about the possibility of a local conflict. Imperialists want to make use of discord between Asian countries to instigate conflicts and profit from them; they are happy to see a conflict in Kashmir. Asian countries hope the situation can be stabilized, reducing military expenditure and engaging more in the work of construction. Our worries are not completely baseless, so we hope and call for the two friendly countries of India and Pakistan to become reconciled. ",116

At the same meeting, the Pakistani ambassador defended his country, reporting that it had tried to directly contact India eight times. However, India rejected all the contact attempts. For this reason, Pakistan considered it necessary to bring the issue to the UN. The ambassador's defense did not convince Zhou Enlai, insisting that it was not a good idea. Zhou Enlai explained that:

"While in Pakistan, I already spoke to your president and premier about the negative consequences of going to the United Nations. The United States will make use of that, and the United States will want to colonize Kashmir. That result would be even worse than [what's happening] now; neither India nor Pakistan could gain anything from it. $"$ "117

In the same meeting, Zhou Enlai also asked the Pakistani Ambassador whether Pakistan would use armed forces, if all other options regarding Kashmir ran out. The Ambassador replied that Pakistan would not consider using force before the UN announced that there were no solutions to the Kashmir issue. Zhou Enlai again expressed his distrust in the UN as follows:

"We do not approve of submitting issues to the United Nations. I once spoke to your foreign minister about this when I was in Peshawar. Do not speak to us of United Nations issues; as soon as the United Nations is mentioned, it provokes us. We have nothing to do with the United Nations; we are averse to the United Nations organization (not to its charter.) "118

On the 19 July 1961, Chinese Deputy Foreign Minister Geng Biao said to the then Indian Ambassador to China Parthasarathy that:

"India and Pakistan were once one nation; after Partition they became two sovereign nations, like twins, two brothers. As for Kashmir, that is a dispute the British deliberately left for India and Pakistan at the time of Partition; that is no secret. My personal opinion is that if it had been decided at the time that Kashmir would go to India, or to Pakistan, or one half to each, there would never have been the Kashmir dispute there is today. Since Britain has created this problem, what should be done to resolve it? We have always believed that it should be resolved through friendly negotiations between India and Pakistan, and foreign countries should not interfere. Of course, there are now some who want to use this dispute to reach their goal of interfering. "119

\footnotetext{
116 Wilson Center Digital Archive International History Declassified, 16 February 1957, Premier Zhou Enlai Receives Pakistani Ambassador Ahmed, and Accepts Letter From Pakistani Premier Suhrawady Explaining the Kashmir Issue 16 Obtained by Sulman Khan and translated by Anna Beth Keim. [online] Available at:

http://digitalarchive.wilsoncenter.org/document/112749.pdf?v=22846ee5f9688ac2893645c1687e22f2 [Accessed 27.03 $2017]$.

${ }^{117}$ Ibid.

118 Ibid.

119 Wilson Center Digital Archive International History Declassified Memorandum of Conversation: Deputy Foreign
} 
In the statement above, the Chinese foreign minister argues that imperialist powers created the Kashmir problem and that these imperialist powers do not hesitate to profit from it. Therefore, one cannot detect a collaboration attempt to mediate the crisis.

In another meeting on the 08 March 1962 between the then Chinese Premier Zhou Enlai and Pakistan's Ambassador to China Ali Muhammad Rashidi, China reiterated that the problems between Pakistan and India should be resolved by direct talks, not by third party intervention. Third party intervention can only empower imperialist powers. Zhou Enlai highlighted that:

“...in Pakistan's dispute with India, resolving matters through direct negotiations is better than going through the United Nations, because the UN has many limitations. The UN is a tool of American imperialism, which could not possibly be impartial, and instead is used by the US whenever it needs to add pressure on this issue or that issue. Therefore, easing relations with India can lighten Pakistan's burdens, saving money that can be used for economic development and reducing its likelihood of falling into imperialism's trap. ",20

These statements from Chinese officials reveal China's concern that the crises between India and Pakistan facilitate imperialist powers' hegemony in South Asia. For this reason, China urges Pakistan and India to resolve the crises through direct talks.

Expectation 1 is that major powers exhibit competitive behaviors in mediating conflicts without a nuclear dimension. The actions of the US, the Soviet Union, and China in the 1947 IndiaPakistan conflict seem contradictory to Expectation 1 because they did not compete with each other. They were hardly involved in the conflict. The US and the Soviet Union did not use belligerent or blaming language against each other. In evaluating the outcome, however, one should consider the historical context. There are two main reasons why Expectation 1 was not realized. First, there were other political developments that distracted the mediators' attention away from South Asia. Both the US and the Soviet Union were focusing on the political developments in Europe after the Second World War. South Asia was not a top priority of the US and the Soviet Union had not yet exhibited its position regarding South Asia at the time of the 1947 conflict. China was engaged in a civil war. There were therefore no aggressive policies or blaming and belligerent discourses from mediator states to each other in South Asia.

\footnotetext{
Minister Geng Biao and Director Zhang Wenji with Indian Ambassador to China Parthasarathy, 19 July 1961 [online] Available at:

http://digitalarchive.wilsoncenter.org/document/121757.pdf?v=dd981a0e361c5df5bf6326eb0e951db7 [Accessed 27.03.2017].

${ }^{120}$ Wilson Center Digital Archive International History Declassified Summary of Conversation between Premier Zhou Enlai and Pakistan`s Ambassador to the PRC, Rashidi (Excerpt), 08 March 1962 [online] Available at: $\mathrm{http}: / /$ digitalarchive. wilsoncenter.org/document/121570.pdf?v=770f07ac805899ceceb28538d937210c [Accessed 27.03.2017].
} 
The importance of South Asia for the major powers increased in the 1950s, and the interest and the belligerent language of the major powers manifested itself as well. The analysis of the relationships between the US, the Soviet Union and China in the 1950s demonstrated that once the region became more important, the attention of mediator states also increased. This mediation attempts, however, were characterized by competitive behavior. Expectation 1 was therefore not realized specifically at the time of the 1947 conflict. However, political developments throughout the 1950s demonstrated competitive behavior between major powers and involved belligerent language, which met the criteria for Expectation 1.

In the Stalinist years, in the 1950s, the Soviet Union saw both Pakistan and India as under the influence of Western powers and imperialism. In the Khrushchev years, one can observe that the Soviets attempted to align with India, although India was the leader of the Non-Aligned movement. In the years of Khrushchev, the Soviet Union overtly supported the Indian position in the Kashmir conflict. This fits to Expectation 2 that the major powers would side with one part of the conflict. Since the end of the Chinese civil war, China was overtly protesting against the US, the UK and the UN engagement in the region, and overtly discrediting their mediation efforts. This corresponds to Expectation 1: competition among major powers. For China, a major concern was mediation by western powers. Solving the crises between India and Pakistan was not a priority. Moreover, it discredits the mediation effort of the UN, arguing that the UN is under the control of the imperialist powers. However, one should consider here that the UN had not accepted the People's Republic of China as the only representative of China. The Republic of China, Taiwan, was accepted as a representative of China. People's Republic of China was accepted in 1971 as the sole representor of China. One should consider this background information before evaluating China's position on UN actions as a strong evidence of its competitive behavior.

Shortly, the India - Pakistan conflict in 1947 demonstrated that without a nuclear dimension to the conflict, and if the conflicted region is not a strategic priority of the major powers, there is a lack of attention by the major powers. From this sub-case, however, I do not intend to generalize the assumption that whenever the geopolitical significance of the region is low then the attention to the conflict is also low, as it lies outside the scope of my thesis. In this specific sub-case, however, I discuss these factors because they help me to explain why Expectation 1 was not fulfilled specifically in the context of the 1947 crisis.

The crisis ended by the UN Resolutions. However, the UN Resolutions did not resolve the root of the problem. The plebiscite had not taken place and Kashmir continued to be a source of the frictions between India and Pakistan, leading to a second war between the two countries. The second conflict can be broken down into two parts. The first part is the Rann of Kutch Crisis, which 
was a small-scale conflict, and the second part is the subsequent large-scale war in 1965. In the following sections, I analyze these two wars.

\subsubsection{The Rann of Kutch Crisis}

\subsubsection{Overview}

Rann of Kutch is a seasonal salt marsh area located in the Kutch district of Gujarat in India and in the Sindh province of Pakistan. The area is largely desert, and therefore, the border between India and Pakistan was not clearly demarcated at the time of India's independence. On 14 July 1948, Pakistan warned India that the Sind-Kutch boundary is a disputed area and must be settled. ${ }^{121}$ Throughout the 1950s, several skirmishes occurred in the region. In January 1960, negotiations between India and Pakistan revealed stark their differences of opinion regarding the border. The talks failed to reach a conclusive agreement. ${ }^{122}$

In early 1965, Pakistani elite troops engaged with Indian troops at Kanjarkon, on the northwest edge of the Rann. ${ }^{123}$ In March 1965, India staged a military exercise in the Kutch region, named Arrow Head. In this exercise, India deployed its air, land, and sea forces. ${ }^{124}$ Indian Prime Minister Shastri made a speech in Hyderabad and stated that "should Pakistan seek to impose a military solution in Kutch, then we will have to act as the situation demands."125

On 9 April 1965, skirmishes started, and intensified between Indian and Pakistani troops in the northern part of Rann. On 24 April 1965, Pakistani forces launched Operation Desert Hawk, attacking the Indian military outpost at Sera Bet in the Rann of Kutch. Pakistan then attacked more bases on the Indian side, and occupied a territory claimed by India. ${ }^{126}$ As a response, India deployed its military units to the area and skirmishes at the brigade level occurred. ${ }^{127}$

The then Indian defense minister, Y.B. Chavan stated in Lok Sabha that some service personnel on leave should be recalled. In the same manner, the Pakistani Commander-in-Chief of the Army Muhammad Musa ordered a general mobilization. ${ }^{128}$

\footnotetext{
${ }^{121}$ Chakravorty, B.C. (1992). History of the Indo-Pak War 1965, S.N. Prasad (ed.), History Division, Ministry of Defence, Government of India: New Delhi, p. 17. cited in McGarr, P.M. (2013). The Cold War in South Asia: Britain, the United States and the Indian Subcontinent 1945-1965. the UK: Cambridge University Press, p. 302

${ }^{122}$ The United Kingdom National Archives, CRO Circular, No.118 The Dispute Between India and Pakistan over the Rann of Kutch, 28 April 1965, PREM 13/391, , Kew, London (hereafter TNA), cited in McGarr, P.M. (2013). The Cold War in South Asia, p. 302.

123 Ibid.

${ }^{124}$ Chakravorty, B.C. (1992). Indo - Pak War 1965, pp. 22-4 and CRO to British High Commissions, ' The Dispute Between India and Pakistan over the Rann of Kutch, 28 April 1965, PREM 13/391, TNA, both cited in McGarr, P.M. (2013). The Cold War in South Asia, p. 303.

${ }_{125}$ The Hindustan Times, 22 March 1965 cited in McGarr, P.M. (2013). The Cold War in South Asia, p. 303.

${ }^{126}$ Chakravorty, B.C. (1992). History of the Indo-Pak War 1965, pg. 31 cited in McGarr, P.M. (2013). The Cold War in South Asia, p. 301.

127 The United Kingdom National Archives Sykes to Bottomley, 'Pakistan: The Rann of Kutch Dispute 16 July 1965 , PREM 13/393, TNA, cited in McGarr, P.M. (2013). The Cold War in South Asia, p. 301.

${ }^{128}$ Chakravorty, B.C. (1992). History of the Indo-Pak War 1965, pg. 34 cited in McGarr, P.M. (2013). The Cold War in
} 
The frictions between India and Pakistan did not last long. The UK Prime Minister Wilson's attempts to mitigate the crisis succeeded, and the Rann of Kutch crisis ended. On 30 June 1965, an agreement was signed and both parties agreed to withdraw their forces. Below, I analyze the main responses to the Rann of Kutch Crisis by the US, the Soviet Union, and China.

\subsubsection{US Mediation of the Rann of Kutch Crisis}

In this crisis, the US did not employ an active mediation strategy. It mainly supported the British mediation effort initiated by the then British Prime Minister Harold Wilson and incited both India and Pakistan to use the good offices of the Britain. For example, the Pakistani Foreign Minister Zulfikar Ali Bhutto met with the US Ambassador to Pakistan, McCanoughy. Bhutto wanted to know whether the US would support Pakistan in the conflict. McCanoughy responded that the US would stand by its commitments, but did not specify which country it would support. Moreover, McCanoughy recommended that Bhutto accepts the requirements of the cease-fire proposed by the United Kingdom. ${ }^{129}$

In 1954, the US and Pakistan had signed the Mutual Defense Assistance Agreement. However, most of the US commitments to Pakistan were valid under the condition that Pakistan was victim to an act of aggression. ${ }^{130}$ However, in the Rann of Kutch crisis, the US was hesitant to identify whether the aggressor was India or Pakistan. Therefore, it put US commitments in question and caused uncertainty to the minds of Pakistani decision-makers. For example, in his telegram on 30 April 1965 to the US Department of State, Ambassador McCanoughy recommended that Pakistan be given an ambiguous message regarding Washington's response against possible aggression by India. The recommendation of McCanoughy is below:

"I would not recommend immediate response to Bhutto reassuring government of Pakistan on effectiveness of past assurances against aggression, since a little uncertainty on their part for next few days could provide the additional leverage needed to achieve cease-fire. However, I do not think that we can postpone providing these reassurances very long without risking very serious damage to our position here. At same time, I strongly urge that government of India be reminded immediately of the standing explicit US assurances to Pakistan as a further deterrent against an Indian contemplation of retaliatory action against Pakistan in another area, such as East Pakistan. "131

However, McCanoughy also highlighted that in the case of aggression, India should also be made aware of firm US assurances to Pakistan. McCanoughy's recommendation that India should also be aware of US assurances to Pakistan reveals US support for Pakistan.

South Asia, p. 303.

${ }^{129}$ The American Papers Secret and Confidential India-Pakistan-Bangladesh Documents 1965-1973 Telegram from the US Embassy in Pakistan to the US Department of State 30 April 196510.45 comp. by Roedad Khan Oxford: Oxford University Press, 1999 pp. 3-5.

${ }^{130}$ Khan, M. Z. and Emmerson, J.K. (1954). United States - Pakistan Mutual Defense Assistance Agreement. Middle East Journal, Vol. 8, No. 3, 19 May 1954, pp. 338-340.

${ }^{131}$ FRUS 1964-1968, Volume XXV, South Asia Telegram from McConaughy to Department of State, 30 April 1965 [online] Available at: https://history.state.gov/historicaldocuments/frus1964-68v25/d114 [Accessed 27.03.2017]. 
Financial means was also an important component of US mediation. US tactic was to soften up India and Pakistan through financial aid cuts, forcing them to adopt US terms. For example, Robert Kormer, a former staff member of the National Security Council, gave a briefing to US President Johnson explaining that the US financial cut would shock both India and Pakistan. The vital part of the recommendation is below:

"You do not want to have Ayub and Shastri" ${ }^{132}$ to here until we have worked out our new policy line, and have softened up to the point where they want to come for help rather than come tell you how to run Vietnam. Despite Pakistan's fine economic performance, let's get across quietly but clearly to Ayub that he cannot play China's game while being banked by the US.",133

Here, one can witness the close and complex relationship between financial aid and political aims. An important goal of the Johnson administration was not only to prevent the crisis, but also to punish Pakistan because of its friendly relations with Chinese Premiere Zhou Enlai. The declassified document above reveals that Komer recommends tighter behavior concerning Pakistan and India. He emphasized that by tightening aid to Pakistan and India, Pakistan should understand that they do not have unlimited US backing. This means that they cannot approach China without jeopardizing their relationships with the US. By punishing India, Komer argues that it would prevent the Indian Prime Minister Shastri from commenting on the Vietnam war. From Komer's memorandum, one see that the purpose of tightening aid was not only to force India and Pakistan to make compromises leading to peace, but also to manage the crisis that best fit US interests in the context of the Cold War.

A memorandum prepared by the member of the National Security Council Staff Robert Komer to President Johnson also reveals the difference between merely ending the crisis and ending the crisis in a way that best serves the interest of the mediating actors.

"Since there is a higher risk of a Pak/Indian flare up than any time since 1947, our stalling on MAP (military assistance programs) makes sense as a warning here too. A major risk, however, is that we're driving the Indian military to get more from the Soviets, which doesn't serve our longer term interest. "134

This statement is indicative of the way of thinking among US policymakers. They appreciate the role of military assistance programs in easing the crisis in the South Asia. Nevertheless, they claim that it is not beneficial for US interests in the long run. Cuts in military assistance programs would at least force India to get additional military equipment from the Soviet Union, helping the Soviet-Indian relations further developing. They use the military aid cuts as a valuable tool to ease

\footnotetext{
${ }^{132}$ Mohammed Ayub Khan was the President of Pakistan. Lal Bahadur Shastri was the Prime Minister of India.

${ }^{133}$ FRUS, 1964-1968 Volume XXV, South Asia, Memorandum From Robert Komer of the National Security Council Staff to President Johnson Document 128, 8 June 1965 [online] Available at: https://history.state.gov/historicaldocuments/frus1964-68v25/d128 [Accessed 27.03.2017].

${ }^{134}$ FRUS 1964-1968, Volume XXV, South Asia Memorandum From Robert Komer of the National Security Council Staff to President Johnson in Document 134, 21 June 1965 [online] Available at: https://history.state.gov/historicaldocuments/frus1964-68v25/d134 [Accessed 27.03.2017].
} 
the crises; however, they do it in a way that does not jeopardize the US position in South Asia. Therefore, the policy makers in the US are not only considering easing the crisis but are also doing it in a way that can best serve US interests.

Below is the Soviet attitude during the crisis.

\subsubsection{Soviet Mediation of the Rann of Kutch Crisis}

Regarding the Rann of Kutch Crisis, the Soviet Union released one official statement by the Telegraph Agency of the Soviet Union (TASS) ${ }^{135}$. A TASS statement released on 9 May 1965 regarding the Rann of Kutch Conflict states that:

"If the conflict is not extinguished, its continuing development will drain the forces of India and Pakistan and can lead to a great loss of life, endangering peace. Only the imperialist circles of the Western Powers are interested in such development of events... They strive to create a tense situation in various parts of the world so as to hinder the development of states that have recently won independence, to suppress the national-liberation movement of the peoples." ${ }^{136}$

In this TASS statement, one clearly detects Cold War rhetoric. The Soviet Union blamed western powers and their imperialist intentions for instigating the crisis. Such rhetoric was abundant during the Cold War.

\subsubsection{Chinese Mediation of the Rann of Kutch Crisis}

In a statement released by Xinhua ${ }^{137}$ on 4 May 1965, China clearly chose align itself with Pakistan. It declared that India disregarded the Indo-Pakistan agreement. For this reason, China took the stance that India should bear the full responsibility for the conflict. This position is clearly laid out in the statement below:

"India has recently provoked armed conflict in the Rann of Kutch on the Indo-Pakistan border in an attempt to forcibly occupy this disputed territory by armed attack... The Indo-Pakistan agreement on West Pakistan-India border disputes signed by the two sides in New Delhi on January 11, 1960, clearly stipulates that the Rann is one of the disputed territories on the Indo-Pakistan border and the two countries agree to study relevant material and hold discussions later with a view to arriving at the settlement. However, the Indian Government has gone back on the agreement and claimed that the area is Indian territory and there is no dispute over it. It has sent troops to occupy the area and carried out armed provocation against Pakistan. This is the crux of the present Indo-Pakistan border conflict.

\footnotetext{
135 TASS is a Russian News Agency. It was established as The Telegraph Agency of the Soviet Union. (Телеграфное агентство Советского Союза = ТACC). It was a crucial institution at the Soviet time. It was the only institute which was responsible for disseminating official information. Therefore, analyzing statements released by TASS would be beneficial to identify some aspects of the Soviet foreign policy. After the dissolution of the Soviet Union, it has been overtaken by the Information Telegraph Agency of Russia. In Russian is Информационное агентство России "TACC" = ИTAP ТACC).( Informatsionnoe agentstvo Rossii).

${ }^{136}$ Pravda TASS Statement, 9 May 1965 as translated in Daily Review (Moscow) comp. by Rajendra Kumar Jain. (1979) Soviet South Asian Relations 1947-1978. UK: Martin Robertson \& Company Ltd., p. 61.

${ }^{137}$ Xinhua is the official press agency of the People's Republic of China. Its president is a member of the Central Committee of the Communist Party of China. Therefore, statements made in Xinhua is an important indicator for the Chinese foreign policy.
} 
Such action on the part of the Indian Government once again shows up India's big nation chauvinism and expansionism. The position of the Indian Government on the border disputes with the neighbouring countries has always been truculent and unreasonable and one of rejecting peaceful negotiations. The logic of the Indian Government is ' my territory is mine, yours is also mine, places I occupy are mine and those I want to occupy are also mine.",138

In the same statement, China attributed its own territorial problems to India as well. For this reason, China declared that it sympathized with Pakistan.

"In the prolonged Sino-Indian border disputes and repeated Sino-Indian border conflicts the Chinese Government has long had experience of the big nation chauvinist and expansionist logic of the Indian ruling circles. The Chinese Government and people fully sympathize with and support the solemn and just stand of Pakistan Government in opposing the Indian policy of military expansion and advocating settlement of the border disputes through peaceful negotiations. ",139

In the statement below, one can also identify some elements of Cold War ideological competition. Just as the Soviet Union had done, China also placed blame on US imperialism in triggering the crisis in South Asia and more generally, in the developing world.

"The US imperialism and its followers, on their part, have energetically supported the Indian reactionaries, by giving them money and guns to encourage India's arms expansion and war preparations. They have done so not only to make India a pawn in anti-China crusade but to back India in bullying its neighbouring countries so as to carry out their evil schemes of making Asians fight Asians and disrupting Afro-Asian solidarity. ,"140

At the end of the statement, China again condemned India and labeled Indian acts as chauvinist ambitions. It covertly threatened India that if the situation did not improve, things would worsen.

"The Chinese Government strongly condemns the big nation chauvinist and expansionist policy of the Indian Government. We would like to advise the Indian Government to give primary consideration to the interests of the Indian people and to the Afro-Asian solidarity and thereby settle its disputes with neighbouring countries, through peaceful negotiations. If instead, it insists on having its own way and playing with fire and widens armed conflict it will certainly come to no good end. ",141

This statement made by the Xinhua News Agency clearly outlines China's position in the Rann of Kutch conflict, supporting Pakistan and blaming imperialist forces for the escalation of the crisis. The Chinese statement also reflects the characteristics of the geopolitical and ideological competition of this era in that part of the world.

\footnotetext{
${ }^{138}$ Xinhua News Agency; 4 May 1965 comp. Rajendra Kumar Jain (1981) China - South Asian Relations 1947-1980. The Great Britain: The Harvester Press, John Spiers, p. 63.

${ }^{139}$ Ibid. 74.

${ }^{140}$ Ibid. 74.

${ }^{141}$ Ibid. 74.
} 
During the Rann of Kutch crisis, the US, the Soviet Union and China blamed each other for the conflict between India and Pakistan. This partly meets the criteria under Expectation 1. China especially supported one party of the conflict, Pakistan, and heavily criticized the other party of the conflict, India. These actions meet the criteria of Expectation 1. The decision makers in the US contemplated whether India would be more pushed into the Soviet orbit if military aid was suspended. These considerations reflect the assumptions and discussions of Expectation 1. However, the Rann of Kutch was not a major conflict. It is therefore not possible to infer strong consequences from the Rann of Kutch crisis, even if it reflects the main assumptions of Expectation 1. I, however, included an analysis of the Rann of Kutch crisis because it occurred immediately before the 1965 war, for which some background information is necessary. Moreover, the Rann of Kutch crisis exhibited how unresolved conflicts could expedite another war on a much bigger scale. Below I analyze this major war between India and Pakistan in 1965.

\subsubsection{The India-Pakistan War of 1965}

\subsubsection{Overview}

After the Rann of Kutch crisis ended, Pakistan commenced Operation Gibraltar on 5 August 1965. During Operation Gibraltar, Pakistani controlled guerillas infiltrated the Indian state of Jammu and Kashmir. While this incited clashes between Indian forces and the guerrillas, the regular armies of the two states first clashed on 14 August. On 15 August, India secured several important geographical mountain positions in the northern area. This development triggered a Pakistani counterattack - where Pakistan bombed Indian troops concentrated near Titwal, Uri, and Poonch. In return, this led to an Indian thrust into Pakistani controlled Azad Kashmir. Indian forces eventually captured the Haji Pir pass, which is five miles within Pakistani territory. ${ }^{142}$

These Indian gains caused a major Pakistani offensive called Operation Grand Slam on 1 September. Pakistan was successful at the beginning and captured the village of Jaurian on 5 September. This village was important because not only was it 14 miles inside of Indian territory, but Pakistan also wanted to use Jaurian as a base to proceed to the town of Akhnur. Capturing Akhnur would have isolated the state of Jammu \& Kashmir from the rest of India. ${ }^{143}$ The Akhnur region was also not easy to defend. Therefore, India reciprocated by launching two offensives in Punjab, one directed to Lahore and another one to Sialkot, to enforce Pakistani withdrawal from Akhnur. ${ }^{144}$ These attacks led India to capture some villages on the way to Lahore, making the situation even more critical for Pakistan. With the aim of keeping India out of Lahore, Pakistan

\footnotetext{
${ }^{142}$ Ganguly, S (1994). The Origin of War in South Asia: Indo - Pakistani Conflicts Since 1947. Colorado, the US and Oxford, the UK: Westview Press, Inc. p. 47.

${ }_{143}$ Ganguly, S (1994). The Origin of War in South Asia, pp. 47-48.

${ }^{144}$ Ganguly, S (1994). The Origin of War in South Asia, p. 48.
} 
attacked Khem Karan on the Indian side of Punjab. India had stopped Pakistani attacks in this region with mass causalities on the Pakistani side. In Sialkot, there was a battle with tanks, which became the main clash of the war. In the end, Indian forces were not be able to capture the city of Sialkot, with an ambiguous outcome as to which side won. ${ }^{145}$

On 8 September, the US and the UK cut military aid in order to stop the conflict. ${ }^{146}$ The UN Security Council finally passed a unanimous resolution on 20 September 1965. In this resolution, the Council demanded a cease-fire on the morning of September 22 and a subsequent withdrawal of all armed personnel to their previous positions. Only after the meeting the conditions of the resolution, did the Council consider necessary steps for a final solution to the conflict. Indian and Pakistani governments accepted the resolution on 21 September and 22 September, respectively. ${ }^{147}$ The war ended on 23 September 1965. ${ }^{148}$ This resolution was as below:

"A ceasefire should take effect on Wednesday, Sept 22, 1965, at 0700 hours GMT, and calls upon both Governments to issue orders for a ceasefire at that moment, and a subsequent withdrawal of all armed personal back to positions held by them before Aug.5, 1965."149

The resolution first required the halting of all hostilities and then considered a discussion of how to resolve the problem. A settlement of the crisis was achieved with the Tashkent Agreement. On 17 September, Alexei Kosygin, the then Premier of the Soviet Union, proposed that Indian and Pakistani leaders should meet in Tashkent or in another Soviet city to discuss their differences under his chairmanship even before the UN Resolution on 20 September. Lal Bahadur Shastri announced on 22 September that he had accepted the Soviet offer. On 25 November, almost three months later, Pakistan accepted as well, after it realized that the UN was unable to offer a concrete solution. In the Soviet mediation part, I will analyze the Tashkent agreement in detail. ${ }^{150}$ Below, I outline US behavior in the Pakistan War of 1965.

\subsubsection{US Mediation of the India - Pakistan War of 1965}

The first clear mediation attempt by the US occurred on 1 September 1965. Chester Bowles, the US Ambassador to India, met with the Indian Minister of External Affairs Swaran Singh and the Foreign Secretary of the Indian Ministry of Foreign Affairs, Shekhar Chandra Jha. At the time of the meeting, Pakistan had already infiltrated Kashmir. The US was afraid of a reciprocal Indian movement from another part of the India-Pakistani border in which India had more of an advantage

\footnotetext{
145 Ibid.

${ }^{146}$ Lamb, A. (1966). Crisis in Kashmir, pp. 124-125.

${ }_{147}$ Brines, R. (1968). The Indo-Pakistani Conflict. London: Pall Mall Press, pp. 373-375.

${ }^{148}$ Lamb, A. (1966). Crisis in Kashmir, pp. 126-127.

${ }^{149}$ UN Resolution 211 (1968). 20 September 1965 pp. 14-15. [online] Available at: http://www.un.org/en/ga/search/view_doc.asp?symbol=S/RES/211(1965) [Accessed 22.03.2017].

${ }^{150}$ Lamb, A. (1966). Crisis in Kashmir, pp. 132.
} 
than it did in the Kashmir region. Bowles urged Swaran Singh to take a reasonable position that could prevent an outbreak of war on the subcontinent. He did this by drawing Singh's attention to the fact that a counter attack by India would trigger a war that would be difficult to control. ${ }^{151}$

In terms of Pakistan, the US pursued a more discouraging strategy. As in the Rann of Kutch crisis, Pakistan reminded the US of its responsibilities as an ally to protect Pakistan. However, the US again refrained from identifying India as an aggressive actor. Moreover, it blamed Pakistan for its role in increasing the tension. This is illustrated in the below telegram sent by the US Department of State to the US ambassador in Pakistan.

"It is clear from the United Nations Secretary General report that immediate crisis began with substantial infiltration of armed men from the Pakistan side. "152

Another meeting between Zulfikar Bhutto and the US Ambassador to Pakistan, McConaughy was even harsher. Bhutto sought to involve the US in the crisis and reminded the US of their duty to support Pakistan as an ally. McConaughy, however, asserted that the US already concerted all of its resources behind the UN Security Council and the Secretary General. In response, Bhutto protested, and asserted that:

"If only reason for bilateral agreement with US were to refer to UN then Pakistan might as well not have that agreement. US/Pak agreement is special arrangement and obligation US with respect Pakistan. To refer government of Pakistan now to UN is to say US not willing fulfill its obligations. "153

There are several other examples that reveal the real concerns of the US in mediating the crisis. One example is the US fear of China from which can be elucidated from a telegram sent by the then US Secretary of State Dean Rusk to the US Embassy in India. This telegram demonstrates that while preventing the conflict was important for the US, a crucial motive was to hinder the spread of the conflict into East Pakistan. If the conflict had spread to East Pakistan, it could have invited China to the conflict. This would complicate the situation and was not in the best interest of US foreign policy, given the Cold War context. Below is the relevant part of this telegram.

"As seen from here there are very urgent reasons why we should attempt to prevent Indo-Pak fighting from expanding into the Bengal-East Pakistan area. Quite apart from strong humanitarian reasons for not extending ground and air operations in area of massed populations, the military situation in the West still appears to be somewhat

\footnotetext{
151 FRUS 1964-1968, Volume XXV, South Asia Telegram From the Embassy in India to the Department of State Volume XXV, South Asia, Document 177, 1 September 1965 [online] Available at: https://history.state.gov/historicaldocuments/frus1964-68v25/d177 [Accessed 27.03.2017].

${ }^{152}$ The American Papers Secret and Confidential India-Pakistan-Bangladesh Documents 1965-1973 Telegram from the US Department of State to the US Embassy in Pakistan 6 September 1965 comp. by Roedad Khan Oxford: Oxford University Press, 1999, pp. 28-29.

${ }^{153}$ FRUS Volume XXV, South Asia Telegram from the US Embassy to the Department of State, Document 198,9 September 1965 [online] Available at: https://history.state.gov/historicaldocuments/frus1964-68v25/d198 [Accessed 27.03.2017].
} 
tentative and possibilities of getting cease-fire and pullback still exist. Opening up of front in the Eastern subcontinent would be further major inflammation and would substantially increase risks of Chinese involvement. ",154

A declassified telephone conversation recorded between the then US President Johnson and the US Defense Minister McNamara also obviously demonstrates US calculations under the Cold War context. This document reveals that McNamara was concerned about contingencies that might develop and which contingency the US was not ready to cope with. For McNamara, the least desirable situation would be China intervening in a position against India, possibly leading to war in South Asia. ${ }^{155}$

In fact, China concern played a predominant role in the US calculations. This is perhaps obvious, given an ultimatum sent by China to India. In this ultimatum, China threatened India, stating that India must withdraw its military units in the China-Sikkim boundary within three days, or else it would face grave consequences. The ultimatum by China was extremely disturbing for the US, because, as the above declassified documents indicate, a major concern of the US was to prevent China from intervening in the conflict and to contain communist influences in South Asia. For this reason, the US intensified its effort to convince Pakistan to distance itself from China. One of the concrete US diplomatic attempts regarding this topic came when the US Ambassador to Pakistan, McCanaughy met with Pakistani President Ayub. In his meeting, McConaughy did not overtly mention the commitments of the US and how the US would react in the face of Indian aggression, but instead, tried to secure firm assurances from Ayub that Pakistan would distance itself from Chinese commitments. McCanoughy made the distancing a condition for Pakistan if it wanted even a little support against Indian aggression. The real concern for the US was the expansion of communism and how to contain it. McConoughy reports from his meeting with Ayub to the US Department of State, as stated below:

"I focused conversation on implications of ChiCom" ${ }^{156}$ ultimatum and on inescapable and imperative requirement for unconditional cease-fire under United Nations Security Council resolutions. I said without arguing background, position at this moment is that ChiComs have it within their power to put Pakistan in impossible situation unless GOP ${ }^{157}$ moves before expiration of ChiCom ultimatum to reject threatened Chinese intervention and implement unconditional cease-fire with India. Anything short of this would put Pakistan in position of seemingly abetting or at least passively benefiting from ChiCom aggression against India. This would be posture which United States Government and people could not accept. It would be impossible for Pakistan or anyone else to prove ChiComs had not been influenced in their decision by Pak failure to disassociate themselves. Such Pakistani position could not be defended before American Government and people, and I did not know how we could get back on our traditional basis

\footnotetext{
${ }^{154}$ FRUS Volume XXV, South Asia Telegram from the Department of State to the Embassy in India, Document 192,8 September 1965 [online] Available at: https://history.state.gov/historicaldocuments/frus1964-68v25/d192 [Accessed 27.03.2017].

${ }^{155}$ FRUS Volume XXV, South Asia Editorial Note 1964-1968, Document 193 [online] Available at: https://history.state.gov/historicaldocuments/frus1964-68v25/d193 [Accessed 27.03.2017].

${ }^{156}$ ChiComs stands for Chinese Communists in the documents.

${ }^{157}$ GOP stands for Government of Pakistan and GOI stands for Government of India.
} 
after such a disaster....Even a semblance of Pakistani association with ChiComs in exertion of Communists military pressures on any free country would put Pakistan beyond reach of U.S. help." ${ }^{\text {,I58 }}$

These conversations demonstrate how the US predicted the Soviet Union and China would behave, if faced with war between India and Pakistan. As such, the US first considered the positioning of others, and only later ending the crisis.

A dialogue between the US Ambassador in India and India's President Sarvepalli Radhakrishnan indicate that the US sought to influence India to turn against China. The ambassador advised the Indian President that India should make peace with Pakistan as soon as possible so that it can direct all of its resources against China. It is hence easy to see that US purpose was not only to prevent a war on the subcontinent, but also to mobilize countries against a Chinese communist threat. $^{159}$

The briefing below from the Secretary of State Rusk to US President Johnson also points out that the US considered its own interests before others in mediating the crisis. He informed the US President that:

"If Kashmir were the only issue, the US could reasonably hope to stand aside. However, the whole Western power transition in Asia may shortly be at stake."

In this briefing, Rusk argued that if the US stood aside, the situation would raise doubt about US commitments among other allies such as Iran and Turkey. They would then begin to question US assurances in times of actual crises.

One can detect geopolitical considerations in the US mediation of the 1965 crisis. The main concern of the US was the increase in Chinese influence among Asian nations. In this respect, the US and the Soviet Union shared the same concerns because the rift between the Soviet Union and China increased during this time period. The US, however, approached China during the presidency of Nixon to exploit the rift between the Soviet Union and China.

This US attitude therefore meets Expectation 1 by not collaborating with other mediator states, where the US even tried to hinder the mediation attempts of China. On the other hand, the US was not opposed to the Soviet sponsored meeting in Tashkent that led to the Tashkent Agreement because it shared the same interest of preventing the increasing Chinese influence. One can argue that US behavior did not meet the actions mentioned in Expectation 2, which is that competitive mediation reduces the effectiveness of pressure for both parties because each mediator

\footnotetext{
${ }^{158}$ FRUS Volume XXV, South Asia, Telegram From the Embassy Office in Pakistan to the Department of State, Document 217, 20 September 1965 [online] Available at:

https://history.state.gov/historicaldocuments/frus1964-68v25/d217 [Accessed 29.03.2017].

${ }^{159}$ FRUS Volume XXV, South Asia, Telegram from the Embassy in India to the Department of State, 11 September 1965 [online] Available at: https://history.state.gov/historicaldocuments/frus1964-68v25/d201 [Accessed 29.03.2017].

${ }^{160}$ FRUS Volume XXV, South Asia, Memorandum from Secretary of State Rusk to President Johnson 9 September 1965 [online] Available at: https://history.state.gov/historicaldocuments/frus1964-68v25/d196 [Accessed 21.03.2017].
} 
state supports the state with which it has good relations. It was therefore to expect that the US should have supported Pakistan, but should not have criticized it. As explained above, however, the real US concern was that a prolonged war could have increased Chinese influence in the region. The US, therefore, harshly criticized Pakistan's approach to China without giving second thought as to whether the Chinese involvement would be beneficial to end the crisis by pressuring India. The US worried that the alignment of a western ally, Pakistan, with communist China would jeopardize US interests in the region. An immediate ending of war was better for US interests. In this respect, the US criticized Pakistani actions. Expectation 3 is also met because Pakistan tried to play the China card in order to receive more US support. Only after understanding that the US stance against Chinese role is firm did Pakistan begin to reduce Chinese influence in its affairs. However, developing relations with China in this period did provide the basis of future strong relations with China. Pakistan later played a crucial role in the US-China rapprochement.

\subsubsection{The Soviet Mediation of India - Pakistan War of 1965}

The Soviet Union played an active role in the 1965 conflict between India and Pakistan. The Soviet Premier Kosygin and other Soviet Representatives in the UN Security Council had many conversations with other states regarding the conflict. In the end, the conflict was resolved by a Soviet initiative called the Tashkent Agreement. Despite this active role, Soviet politicians generally used defamatory language against the US and the West in general regarding their alleged role in instigating the conflicts between India and Pakistan. Below are some examples of the Soviet position on the conflict.

In his speech to the UN Security Council, Soviet representative Marozov asserted that the conflict between India and Pakistan was a legacy of colonialism. He also blamed western powers for trying to profit from the conflicts between India and Pakistan. Marozov aimed to highlight the superiority of the Soviet values and defended these values against the West. It also pointed out the relevancy of these values in solving the problems in Third World countries. In his statement, a sign of collaboration with the West to ease this crisis was not detected. Below is his speech:

"My delegation has repeatedly pointed out that the tension between these two important Asian States over Kashmir is one of the grim legacies of colonialism. The imperialists have always tried to use the Kashmir question to stir up quarrels between the peoples of India and Pakistan, to set them against each other now that they have freed themselves from colonial bondage, to undermine their solidarity, to aggravate international relations and exploit the situation this created for their own selfish purposes, and to create in Asia yet another hotbed of tension." 161

\footnotetext{
${ }^{161}$ UN Document S/PV 1237, 35-7 comp. Rajendra Kumar Jain. (1979) Soviet South Asian Relations 1947-1978. UK: Martin Robertson \& Company Ltd. p. 68-70.
} 
An example of a mediation effort was a message sent by the then Soviet Premier Kosygin to Indian Prime Minister Shastri on 4 September 1965. He stated that:

"The tendency towards a further expansion of the armed conflict aggravates the already tense situation in South and South-East Asia created by the aggression of United States imperialism. Such developments, of course, serve the purposes only of those external forces that seek to divide the States which have liberated themselves from the colonial yoke and to set one against other, forces that are interested in weakening the unity of Afro-African countries. "162

In the message by Kosygin to Shastri, a conflictive rhetoric can be detected. He believed that US imperialism was responsible for all negative events. In the second part of the message, Kosygin offered to actively mediate the crisis:

"Acting in the Spirit of the United Nations Charter and the Bandung principles, the parties should enter into negotiations for the peaceful settlement of the differences that have arisen between them. As for the Soviet Union, both sides could count on this willing co-operation or, to use the accepted expression, on its good offices in this matter. We are ready for this, if both sides consider it useful." 163

In this statement, Kosygin explicitly offers assistance by the Soviet Union to solve the crisis. Nonetheless, his speech has confronting rather than collaborating discourse, and there is little evidence of willingness to cooperate with the West to mediate the conflict.

On 4 September 1965, Kosygin sent an identical letter to the Pakistani President Ayub Khan. In this letter, he blamed US imperialism and claimed that the roots of the crisis stems from imperialist agendas of western powers. He also offered assistance to mediate the crisis in this letter. ${ }^{164}$ Both President Ayub Khan and Lal Bahadur Shastri rejected the offer. ${ }^{165}$

In another official statement released by TASS on 7 September 1965, imperialism and the West were criticized again. It was likewise unconducive towards easing the crisis.

"There is no doubt that the armed conflict in the Kashmir region cannot benefit either of the sides. Present developments in that region play into the hands only those outside forces that seek to disunite and set at loogerheads the States that cast off the colonial yoke. In the past, too, these forces have more than once tried to exploit the Kashmir issue to prevent the establishment of good-neighbourly relations between India and Pakistan, seeking to set them at loggerheads. They are undoubtedly, now, too, instigating India and Pakistan to extend the bloodshed for the sake of their ends which run counter to the national interests of the Indian and Pakistani people who are vitally interested in the strengthening of peace.",166

\footnotetext{
${ }^{162}$ UN Document S/6685, Message from Mr. Kosygin Addressed to Prime Minister Shastri of India, 4 September 1965, pp. 2-3 [online] Available at: http://www.un.org/en/ga/search/view_doc.asp?symbol=S/6685 [Accessed 24.03.2017].

163 Ibid.

${ }^{164}$ Ibid. p. 72-74

${ }^{165}$ Lamb, A. (1966). Crisis in Kashmir, p. 132.

${ }^{166}$ UN Document S/6671, TASS Statement, 7 September 1965 [online] Available at:
} 
TASS statement on 13 September 1965, as seen below, also reveals that the Soviet Union held US imperialism responsible for all the unfortunate events in South Asia. This statement clearly demonstrates that the Soviet Union does not envisage the possibility of collaborating with the US in order to ease the conflict.

"The incoming reports show that the Indo-Pakistani armed conflict is gaining ground...The growing military actions between India and Pakistan coupled with the continued aggression of American imperialism in Vietnam increase still more the danger to peace in South and South-East Asia and the rest of the world. Howsoever the causes behind the hostilities between India and Pakistan are appraised, one thing is clear: their further extension would benefit only the forces of imperialism, only those who would like to re-impose the yoke of colonialism and neocolonialism on the liberated peoples. Even now, American imperialism is trying to exploit the military clashes between India and Pakistan to divert the people's attention from the US aggression in Vietnam. ",167

On 17 September 1965, Kosygin proposed again that Indian and Pakistani leaders should meet at Tashkent or some other Russian city to talk about their differences. ${ }^{168}$

On 18 September 1965, Nikolai Fedorenko, the Soviet representative in the Security Council stated:

"The spread of the armed conflict is aggravating the already tense situation in South and South-East Asia, created by the aggression of United States imperialism in Vietnam, and is still further increasing the threat to world peace... It is all evident that the armed conflict between India and Pakistan merely serves the purposes of the forces who are trying to disunite and set against each other the States that have liberated themselves from the colonial yoke. It is equally clear that the continuation of this conflict benefits only the forces which are pursuing the criminal policy of dividing peoples so as to achieve their imperialist and expansionist aims. "169

Here, the Soviet Union stated in the UN Security Council that the conflict in South Asia had been inflated by imperialistic intentions. These charges were put before the UN Security Council and demonstrated that Soviet accusations of the US particularly, and of the West generally, were not merely for domestic political reasons. The statement brings these allegations to the international forefront. Therefore, this attitude further complicated the possibility of collaboration between the Soviet Union and the West.

\footnotetext{
http://www.un.org/en/ga/search/view_doc.asp?symbol=S/6671 [Accessed 22.03.2017].

${ }_{167}$ Soviet Review (New Delhi), 18 September 1965, 8-10 comp. by Rajendra Kumar Jain. (1979). Soviet South Asian Relations 1947-1978. TASS Statement. UK: Martin Robertson \& Company Ltd., pp. 76-78.

${ }^{168}$ Lamb, A. (1966). Crisis in Kashmir, p. 132.

${ }^{169}$ UN Document S/PV 1241, 25-8. comp. Rajendra Kumar Jain. (1979). Soviet South Asian Relations 1947-1978. UK: Martin Robertson \& Company Ltd. pp. 80-81.
} 
On 22 September, Lal Bahadur Shastri positively responded to Kosygin's offer from 17 September to hold a peace conference in Tashkent. On 25 November, Pakistan also finally accepted Kosygin's offer. ${ }^{170}$

The Tashkent Conference started on 3 January 1966 and ended on 10 January 1966. It was not an easy conference to lead. Although Kosygin succeeded in stopping the war, the Kashmir problem was still not resolved. The Tashkent Conference applied the method of incremental improvement to India-Pakistan relations. The most fundamental problem, Kashmir, was first put aside in order to solve other more pressing issues: The immediate end of war, the redeployment of both armies behind the cease-fire line that was drawn in 1949, and the immediate reestablishment of diplomatic relations. Additionally, India and Pakistan agreed to pursue high-level contacts on matters of direct concern to both countries. In February 1966, both sides withdrew from behind the cease-fire line and on March 1966, the ministerial level meetings began to discuss the Kashmir problem. $^{171}$

On 10 January 1966, Kosygin also stated that:

"These were difficult talks but it could not be otherwise. For, the disputed problems were accumulated in the course of many years. More, it should be borne in mind that the enmity between Pakistan and India was a heritage of the long period of domination by the colonialists, who set the enslaved peoples at loggerheads with each other.",172

The statements above demonstrated that in mediating the 1965 crisis, the Soviet Union prioritized geopolitical and ideological concerns. Apart from easing the crisis, it also strived to end the 1965 crisis by blaming the US for triggering the crisis. Therefore, on the one hand, the Soviet Union struggled to end the crisis, but on the other hand, it sought to impress both India and Pakistan, as well as achieving some political gains for communist ideology. Furthermore, ending the Indo-Pakistani conflict would endorse Russia's role as an Asian power, one that could help solve problems among Asian nations without having colonialist motives. ${ }^{173}$ For these reason, the Soviet mediation of 1965 war fulfills Expectation 1: competition.

During the crisis, the Soviet Union continued to send the military aids to India although the US and the UK decided to cut off these aids. This was also a competitive move and fits into Expectation 1, since one mediator state stopped providing military aid, and other mediator state

\footnotetext{
${ }^{170}$ Lamb, A. (1966). Crisis in Kashmir, pp. 132-133.

${ }^{171}$ Lamb, A. (1966). Crisis in Kashmir, pp. 133-134 and Foreign Affairs Record (New Delhi) (Jan 1966) 9-10 and the Tashkent Declaration, n. 33, 4-6. The Tashkent Declaration 10 January 1966 comp. by Rajendra Kumar Jain. (1979). Soviet South Asian Relations 1947-1978. UK: Martin Robertson \& Company Ltd. pp. 95-98.

${ }^{172}$ Soviet Review 22 January 1966 7-8 comp. by Rajendra Kumar Jain. (1979) Soviet South Asian Relations 1947-1978 UK: Martin Robertson \& Company Ltd. pp. 98-99.

${ }^{173}$ Lamb, A. (1966). Crisis in Kashmir, p. 133.
} 
stepped in to fill the gap in military aid. In this context, the US cut off aid, which was then provided for by the Soviets. ${ }^{174}$

\subsubsection{The Chinese Mediation of Indian - Pakistan War of 1965}

In an article released by the Peking Review ${ }^{175}$ on 5 September 1965 , one can detect that China blamed India for starting the conflict. It attributes the origin of the conflict to the brutal Indian rule in Kashmir. This statement clearly demonstrates the pro-Pakistani position of China.

"The people in the Indian-occupied sector of Kashmir started large-scale armed resistance early last month because they could no longer tolerate the brutal rule and communal prosecution of the Indian reactionaries...For more than a decade the Indian Government has defied the Kashmir people's demand for self-determination and deprived them of their democratic rights. ",176

It was also stated that India crossed the ceasefire line and therefore, Pakistan was only defending itself. This statement fully corresponds with the official Pakistani account of the crisis.

"While barbarously cracking down on the Kashmir people recently, India has at the same time openly violated the ceasefire line agreed upon between the two countries, sent its troops into the area controlled by Pakistan and launched armed provocations against that country. ",177

In the same article China blamed both the imperialist powers and the Soviet Union. In this part, one can view the Chinese reaction as ideological competition with the West and geopolitical competition with the Soviet Union.

"The fact that the Indian reactionaries dare to carry on this unscrupulous expansionism cannot be separated from the backing and instigation of the United States and some other big powers. For many years, US imperialism has given India enormous sums of money and large quantities of arms. The Khrushchev revisionists, too, have vied with the United States in giving money and arms to India. ,"178

On 7 September 1965, the Chinese Government released an official statement regarding the Kashmir crisis. In this statement, China demonstrated its full support for Pakistan and condemned India. It again blamed western powers for pursuing their own interests in the region.

\footnotetext{
${ }^{174}$ Washington Post, 16 September 1965 cited in Brines, R. (1968). The Indo-Pakistani Conflict. Pall Mall Press Ltd: London, pp. 365.

${ }^{175}$ Peking Review is China's only national news magazine in English. It reports and comments on the country`s social, political, economic, and cultural affairs. The articles written under the name Observer are important because articles against the official position of Chinese Administration cannot be published. The articles written under the name Editorial is more important. They represent the official stance of Chinese Administration in any political issues. Peking Review can be reached in Marxist Internet Archive [online] Available at:

https://www.marxists.org/subject/china/peking-review/ [Accessed 23.03.2017].

${ }^{176}$ Peking Review, Indian Reactionaries' Expansionism. 10 September 1965, Observer, No.37 p. 7 [online] Available at: http://massline.org/PekingReview/PR1965/PR1965-37.pdf [Accessed 27.03.2017].

${ }^{177}$ Ibid.

${ }^{178}$ Ibid. p. 7.
} 
“The Indian Government's armed attack on Pakistan is an act of naked aggression. It is not only a crude violation of all principles guiding international relations, but also constitutes a grave threat to peace in this part of Asia. The Chinese Government sternly condemns India for its criminal aggression, expresses firm support for Pakistan in its just struggle against aggression and solemnly warns the Indian Government that it must bear responsibility for all the consequences of its criminal and extended aggression... On the Kashmir question, the United Nations has once again proved a tool of US imperialism and its partners in their attempt to control the whole world. ",179

In this official Chinese statement, it is evidence that international cooperation was difficult. China blamed the US and the Soviet Union for encouraging Indian belligerence. The same statement plainly reveals the Chinese threat to India as well.

"Since the Indian Government has taken the first step in committing aggression against Pakistan, it cannot evade responsibility for the chain of consequences arising therefrom." 180

On 9 September 1965, China threatened India one more time. While celebrating the Founding of the Tibetan autonomous region in Lhasa, Vice Premier Hsieh Fu-chih sent a strong signal to India. He stated that:

"The Indian reactionaries have always cherished expansionist and aggressive ambitions with regard to China's territories of Tibet and Sinkiang. They have not yet learnt their lesson since their large-scale armed offensive against China was smashed in 1962...Should the Indian reactionaries continue to act arbitrarily and cherish their vain expansionist dreams, they will certainly repeat their previous mistake and suffer a still heavier defeat. ",18I

On 9 September 1965 Premier Zhou En-lai blamed again both the US and the Soviet Union for encouraging India to behave aggressive. At a public reception given by the Korean Charge Charge d'Affaires ad interim, he stated that:

"The Indian reactionaries could not have engaged in such a serious military adventure without the consent and support of the US...In this context the modern revisionists (the Soviet Union) have also played a most unseemly role. They have repeatedly asserted that Kashmiri is an integral part of India. Is this not an open encouragement for the Indian reactionaries to embark on a military adventure? ", 182

Here Premier Zhou En-lai overtly declared a pro-Pakistani policy. He stated that:

"The Indian reactionaries are the aggressors. They are outright aggressors both in the local conflict in Kashmir and in the general conflict between India and Pakistan...,, The Chinese Government firmly supports Pakistan's just struggle against aggression and the Kashmir people's struggle for freedom and the right of national self-

\footnotetext{
${ }^{179}$ Ibid. p. 6.

${ }^{180}$ Ibid. pp. 6-7.

${ }^{181}$ Peking Review, Indian Aggression Against Pakistan. 17 September 1965, No. 38 pp. 10-11 [online] Available at: https://www.marxists.org/subject/china/peking-review/1965/PR1965-38.pdf [Accessed 27.03.2017].

${ }^{182}$ Peking Review Indian Aggression Against Pakistan. 17 September 1965 No.38, p. 10.
} 
determination; it resolutely condemns India for its crimes of aggression and sternly warns the Indian Government that it must bear full responsibility for all the consequences arising from its extended aggression. ",183

An editorial article in the People's Daily also rejected allegations made by India that Pakistani forces infiltrated through the border and initiated the crisis. In this article, it was stated that:

"The Indian reactionaries describe their aggressive action in crossing the ceasefire line as aimed at coping with the so-called 'Pakistan infiltrator'. This, too, is utterly absurd. It is common knowledge that India and Pakistan reached agreement in 1953 that the status of Kashmir should be decided by a plebiscite... The Indian authorities have more than once openly claimed that 'Kashmiri is an integral part of the Indian Union.' This fully exposes their expansionist ambitions... The people in the Indian-occupied sector staged an armed uprising in early August to oppose Indian tyranny and demand self-determination of their own future. This is an entirely just action and no question of Pakistan , infiltration ,, is involved. ", 184

On 14 September 1965, in another editorial article, China's reservations from easing the crisis through international cooperation can be identified. This article blamed not only the US and the Soviet Union, but the UN as well. It asserted that the UN had come under the influence of imperialist powers. It was stated in this article that:

“The United Nations is again playing a most unsavory role this time in India's large-scale armed aggression against Pakistan. In the name of ,, mediation “ it is taking sides with the Indian aggressor and doing all it can to help the Indian reactionaries shored up by US imperialism and its partners... Under the manipulation of US imperialism, the United Nations, consistently reversing right and wrong and calling black white, has always served the interests of aggressors and branded the victims of aggression as the aggressors...Today, the United Nations is again siding with the aggressor on the Kashmir issue and the Indo-Pakistan conflict and bullying hic victim. It has become a sanctuary for the Indian aggressor. The United Nations is a tool of US imperialism. It has done much evil. It cannot do anything $\operatorname{good} . . ., 185$

Apart from these statements above, China already aggressively began to meddle with the crisis in August 1965. Since 1963, China was protesting against the military structures erected by India on the Chinese side of the border between Sikkim and Tibet at the Nathu La and other passes leading into the Chumbi Valley, located within Chinese territory. As the Kashmir crisis intensified, China urged India to withdraw from Chinese territory ${ }^{186}$ India declined China's claims and proposed a neutral observer group to inspect the region. China refused the observers, and urged India to withdraw. ${ }^{187}$ India believed that China did bring the border issues in order to encourage Pakistan. ${ }^{188}$

\footnotetext{
183 Ibid.

${ }^{184}$ Ibid. pp. 12-13.

${ }_{185}$ Peking Review, Indian Aggression Against Pakistan. 17 September 1965, No.38 pp. 14-18.

${ }^{186}$ Lamb, A. (1966). Crisis in Kashmir, pp. 128.

${ }^{187}$ Lamb, A. (1966). Crisis in Kashmir, p. 129.

${ }^{188}$ Ministry of External Affairs, Government of India Annual Reports 1965-66. p. 10 [online] Available at:
} 
On 16 September 1965, China delivered an ultimatum to India at the peak of the crisis. This ultimatum directed Indians to withdraw within three days from Sikkim-Tibet territory. Otherwise, they would face grave consequences. ${ }^{189}$ The ultimatum would expire on 19 September. China extended the time for a further three days before the expiration date. On 22 September, China declared that India had already fulfilled the Chinese requirements and withdrew the ultimatum. ${ }^{190}$ Chinese ultimatum was a source of great concern for India. India had to maintain substantial military troops in the Sikkim-Tibet territory, which had grave consequences on Indian war efforts with Pakistan. Even after the Indian decision to participate in the Tashkent Peace Conference, China continued to threaten India. Vice-Premier and Foreign Minister Chen Yi held a press conference for Chinese and foreign correspondents on 29 September 1965. A correspondent of the London Daily Express asked what assistance the Chinese Government would give Pakistan, if the conflict between India and Pakistan continued. Vice-Premier Chen Yi emphasized that:

"If the Indian troops resume the aggressive war against Pakistan, China will certainly give Pakistan moral and material support.",191

As the data revealed, in the 1965 crisis China firmly supported Pakistan. China also tried to discredit the Tashkent Agreement by claiming that it was "a product of joint US - Soviet planning." 192 These Chinese actions did not embody collaborative behavior.

China's attitude meets the criteria laid out in Expectation 1. China did not collaborate with neither the US nor the Soviet Union. In contrast, it competed with them to seek gains from the conflict. China blamed the actions of the US and the Soviet Union and kept them responsible for the crisis. This attitude fits into the likely actions of the Expectation 1. One can also interpret the Chinese threat to India, sending an ultimatum, as an attempt at solving its own territorial disputes with India by exploiting the crisis. This action by China could therefore be seen as an endeavor to make profit out of the crisis. Moreover, the Chinese attitude fits the actions elaborated in Expectation 2. Expectation 2 assumes that there is no coordination between mediator states and each mediator supports the state with which it has good relations. China overtly supported Pakistani actions and criticized India.

\footnotetext{
http://mealib.nic.in/?pdf2492?000 [Accessed 27.03.2017].

${ }^{189}$ Lamb, A. (1966). Crisis in Kashmir, p. 129.

${ }^{190}$ Ibid. p. 130.

${ }^{191}$ Peking Review, On the Indian-Pakistan Conflict. 8 October 1965, No. 41, pp. 7-8 [online] Available at: https://www.marxists.org/subject/china/peking-review/1965/PR1965-41.pdf [Accessed 27.03.2017].

${ }^{192}$ Ministry of External Affairs, Government of India Annual Reports 1965-66. p. 10 [online] Available at: http://mealib.nic.in/?pdf2492?000 [Accessed 27.03.2017].
} 
The attitudes of India and Pakistan also fit Expectation 3 in that: The parties of the conflict have more maneuvering capability regarding foreign policy (alignment) options. Ayup Khan's and Zulfikar Ali Bhutto's attempts to play the Chinese card show this capability.

\subsubsection{India - Pakistan War of 1971}

\subsubsection{Overview}

After the demarcation of Pakistan and India, Pakistan was divided into two parts, East and West Pakistan. There were no shared borders between these two administrative units. West Pakistan was richer than East Pakistan. Military and industrial elites were located in West Pakistan. West Pakistan was not receptive to the demands coming from East Pakistan and was not interested in the widespread poverty there. All of these factors contributed to the public resentment in East Pakistan which led them to demand more autonomy. The Awami League, the major political party in East Pakistan, won 167 out of 169 seats in the December 1970 elections. West Pakistan invalidated the elections, causing uprisings in East Pakistan. However, the uprising was not united. Some nonBengali East Pakistanis (Biharis) sided with West Pakistan against Bengalis. ${ }^{193}$ This complicated the situation. Bengalis slaughtered Biharis during the uprisings in Chittagong because of their proPakistani position. Pakistan used this as an excuse to launch a massive operation against East Pakistan, called Operation Searchlight. ${ }^{194}$

On the night of 25 March 1971, Pakistan attacked Dhaka. The Awami League was banished and political leaders were arrested. One of the aims of the operation was to disarm disloyal Bengali personnel in the police and army. ${ }^{195}$ Many members of the secession movement relocated to India. The leader of the Awami League Sheikh Mujibur Rahman was arrested and taken to West Pakistan. On 26 March 1971, Ziaur Rahman ${ }^{196}$ declared the independence of Bangladesh on behalf of Mujibur Rahman. In April 1971, exiled Awami League leaders formed a government-in-exile.

As a result of these developments, General Tikha, the commander of Pakistani Forces in East Pakistan, slaughtered the massive Bengali population in East Pakistan. ${ }^{197}$ Many Bengalis

\footnotetext{
193 Bose, S. (2005). Anatomy of Violence: Analysis of Civil War in East Pakistan in 1971. Economic and Political Weekly, 8 October 2005, vol. 40, No.41, p. 4468.

${ }^{194}$ D' Costa, B. (2011). Nationbuilding, Gender and War Crimes in South Asia. New York and Canada: Routledge p. 103.

${ }^{195}$ Bose, S. (2005). Anatomy of Violence: Analysis of Civil War in East Pakistan in 1971. Economic and Political Weekly, 8 October 2005, p. 4465.

${ }^{196}$ He became the seventh president of Bangladesh between 1977 - 1981.

${ }^{197}$ Baixas, L. (2008). Khan (1917/2002) General Tikka, Encyclopedia of Mass Violance, [online] Available at: http://www.sciencespo.fr/mass-violence-war-massacre-resistance/fr/node/2705 [27.03.2017].
} 
started to flee East Pakistan, creating a large refugee problem in India. Nearly 10 million ${ }^{198}$ refugees were to be absorbed into the Indian economy. ${ }^{199}$ In addition, India was concerned about the strong ties between West and East Bengals on the ground that significant number of refugees could destabilize their own Bengali (West) region. ${ }^{200}$ After appealing to the international community without any success, India decided to develop massive military units near the border areas. On 23 November, Pakistani President Yahya Khan declared a state of emergency and announced that a war with India was highly possible. ${ }^{201}$

On the evening of 3 December, the Pakistani Air Force (PAF) launched a pre-emptive strike on airfields in north-western India, including Agra ${ }^{202}$ This preemptive air strike was called Operation Cengiz Khan. Prime Minister Indira Gandhi held that air strikes were a declaration of war against India. This incident marks the official start of this conflict.

Pakistan initiated attacks in Jammu \& Kashmir, Punjab, and Rajasthan sector on the western front in order to keep India at bay from East Pakistan. ${ }^{203}$ The clashes in Chamb in the Jammu and Kashmir region were harsh and Pakistan had shown some success there. India had not launched a massive land aggression on the western front because its expectations in the western front were modest. Nevertheless, the Indian navy initiated two successful attacks. On 4-5 December 1971, the Indian Navy attacked Karachi port in the Western theatre. This operation was called Operation Trident. Thereafter, Operation Python took place on 8-9 December 1971. In this operation, Indian missile boats attacked the Karachi port and caused heavy damages. ${ }^{204}$

India also launched a massive land attack together with Mukti Bahini forces ${ }^{205}$ in the Eastern Sector. The Pakistani air force tried to retaliate, but the Indian air force quickly destroyed Pakistani air capabilities in East Pakistan. ${ }^{206}$ Consequently, Dhaka fell to Indian and Mukti Bahini forces on December 16. It ended the war. East Pakistan became an independent state and took the name

\footnotetext{
${ }^{198}$ UNCHR The UN Refugee Agency: The State of The World's Refugees 2000: Fifty Years of Humanitarian Action. Chapter 3 Rupture in South Asia [online] Available at: http://www.unhcr.org/3ebf9bab0.html pp. 60-61 [Accessed 27.03.2017].

${ }^{199}$ FRUS, 1969-1976 Volume XI South Asia Crisis 1971, Letter from Indian Prime Minister Gandhi to President Nixon. 5 December 1971 [online] Available at: https://history.state.gov/historicaldocuments/frus1969-76v11/d226 [Accessed 27.03.2017].

${ }^{200}$ FRUS, 1969-1976, Volume XI, South Asia Crisis 1971, Memorandum of Conversation. 3 June 1971 [online] Available at: https://history.state.gov/historicaldocuments/frus1969-76v11/d64 [Accessed 27.03.2017].

201 Trivedi, R. (2008). India's Relations with Her Neighbours. India: ISHA Books p. 228.

${ }^{202}$ BBC (1971): Pakistan intensifies air raids on India. [online] Available at: http://news.bbc.co.uk/onthisday/hi/dates/stories/december/3/newsid_2519000/2519133.stm [Accessed 27.03.2017].

${ }^{203}$ Boewe, C. (2006). Indian - Pakistani Wars in Thomas M. Leonard (ed.) Encyclopedia of the Developing World Volume 1 A-E Index. Routledge Taylor \& Francis Group: New York and London. p. 806.

${ }^{204}$ Global Security.org - Military - Indo-Pakistani War of 1971. [online] Available at: http://www.globalsecurity.org/military/world/war/indo-pak_1971.htm [Accessed 27.03.2017].

${ }^{205}$ A guerilla movement in Bangladesh fought for the Liberation of Bangladesh.

${ }^{206}$ Singh, J. (2011). Indian Air Power in John Andreas Olsen (ed.) Global Air Power. The US: Potomac Books, Inc., pp. 236-237.
} 
Bangladesh. This was a large defeat for Pakistan, which also lost its territorial integrity. Major powers also played a role in the crisis but were not successful in preventing the war. Below, I outline the mediation actions of the US, the Soviet Union, and China to the crisis.

\subsubsection{US Mediation of India - the Pakistan War of 1971}

In mediating the 1971 war, the US placed importance on its relations with Pakistan. The statement of the US Secretary of State William P. Rogers to US President Richard Nixon evidently demonstrated that when easing the crisis, the US should prioritize its own interests. Rogers highlighted that a war in South Asia poses a great danger to US interests in the region. He even recommended that for the sake of US relations with the Pakistani President Yahya, the US should not force Yahya to search for political concessions in East Pakistan. Below is a part of his statement:

"The possibility of war introduces a new and greater threat to US interests in South Asia. The threat is likely to remain as long as the East Pakistan conflict remains unresolved. We agree that President Yahya is not likely to take steps to bring about a political accommodation until he realizes, himself, how essential it is. We cannot force him to this realization and therefore we are not imposing political conditions on our assistance. We believe, however, that we should avoid taking actions which might ease the internal pressures on him to take such steps on his own accord." 207

The statement above shows how relations with Pakistan were important for the US, and while ending the crisis was also important, it was sought in a way that no damage was done to relations with Pakistan. The overt pro-Pakistani policy of the US and US President Nixon's close relationship with Pakistani President Yahya is visible in the 1971 crisis. The US declared that the uprisings in East Pakistan were an internal problem of Pakistan. Therefore, it rejected the idea of external interference in this issue. On 5 April 1971, the spokesman of the Department of State stated:

“...We view what is going on in Pakistan as an internal matter... ,208

In a conversation between US National Security Advisor Henry Kissinger and Nixon, the US objected to East Pakistani independence. Kissinger stated:

“...If East Pakistan becomes independent, it is going to become a cesspool. It is going to be 100 million people, they have the lowest standard of living in Asia...No resources. They are going to become a ripe for Communist infiltration. ",209

\footnotetext{
${ }^{207}$ FRUS Volume XI South Asia Crisis 1971, Memorandum from Secretary of State Rogers to President Nixon. 26 May 1971 [online] Available at: http://history.state.gov/historicaldocuments/frus1969-76v11/d58 [Accessed 27.03.2017].

${ }^{208}$ United States Information Service (USIS) Press Release, 6 April 1971 and Pakistan Horizon, no.2, 2nd Quarter, 1971, 145-146. both are comp. by Rajendra Kumar Jain US-South Asian Relations 1947-1982. Statement by the Spokesman of the Department of State, 5 April 1971, Volume 3, p. 3, Document 1, p. 3.

${ }^{209}$ FRUS Volume E-7 Documents on South Asia 1969-1972 Document 136, 4 June 1971 [online] Available at: http://history.state.gov/historicaldocuments/frus1969-76ve07/d136 [Accessed 27.03.2017].
} 
This statement also illuminates one reason for which the US sided with Pakistan. Its unwillingness to support East Pakistani independence stemmed from geopolitical concerns and fear of the spread of communism. Although this conversation between Nixon and Kissinger demonstrates the obvious pro-Pakistani stance of the US, the staff of National Security Council tried to keep their options open. For example, they prepared a contingency plan based on different possible US reactions to the crisis. These scenarios varied from staying neutral to supporting either Pakistan or India. They evaluated the pros and cons of each scenario. They claimed that if they supported Pakistan openly, it would antagonize India and push India closer to the Soviet orbit. If they supported India, although they consider this to be less likely, it would antagonize Pakistan and make the country vulnerable to Chinese influence. They claimed that if the conflict is not prolonged, the best option would be to take a neutral position. If the conflict is prolonged, neutrality would not suit US interests. Below is one example, by the National Security Council, of the contingency plan relating to a scenario of US neutrality.

"The U.S. would assume an essentially passive role toward the conflict indicating our basic neutrality. This would be most appropriate in circumstances where the responsibility for the outbreak of war was unclear or where we judged the likelihood of Chinese military involvement to be small. It would not do irreparable harm to our interests in either country. This posture would also allow us to adopt a mediating position encouraging a negotiated political settlement when circumstances made such a role possible. Such an approach would not be appropriate if there were a prolonged conflict., 210

However, they added that this neutrality would be counterproductive to US interests in the long term, if the war was prolonged. In a protracted war, US neutrality would increase India's dependence on the Soviet Union and Pakistan's dependence on China. This contingency plan shows that the US tried to keep its options open. However, Nixon's insistency to support Pakistan dominated national security discussions. For example, in one of the Washington Special Action Groups $^{211}$ meetings, Kissinger stated:

"I am getting hell every half hour from the President that we are not being tough on India. He has just called me again. He does not believe we are carrying out his wishes. He wants to tilt in favor of Pakistan. He feels everything we do comes out otherwise. "212

From Kissinger's statement, one can detect that the US measures the possible impacts of its actions on its allies rather than merely easing the crisis. Kissinger further stated:

\footnotetext{
210 FRUS 1969-1976 Volume XI, South Asia Crisis, 1971 Document 101, 12 July 1971 [online] Available at: http://history.state.gov/historicaldocuments/frus1969-76v11/d101 [Accessed 27.03.2017].

${ }^{211}$ Washington Special Action Group was a committee of the National Security Council.

${ }^{212}$ Washington Post, 5 January 1972 comp. Washington Special Action Group Meeting on India/Pakistan, 3 December 1971 comp. by Rajendra Kumar Jain US - South Asian Relations 1947-1982 Vol.3, p. 25.
} 
"What may be witnessing is a situation wherein a country (India) equipped and supported by the Soviets may be turning half of Pakistan into an impotent state and the other half into a vassal. We must consider what other countries may be thinking of our action.",213

This statement reveals that the US considered how mediating the India - Pakistan crisis would affect the role of the US and the dynamics among allies.

The US mediation of 1971 crisis meets Expectation 1. The US competed with other mediated states. This fits into the likely actions of Expectation 1. The US sided with Pakistan because of its own foreign policy interests in the region. At the beginning of the crisis, US decision makers worked on different scenarios, but during the crisis US support for Pakistan became more solidified. In particular, US even sent the aircraft carrier Enterprise to the Bay of Bengal in order to demonstrate US support for Pakistan. Siding with one side of the conflict is more plausibly linked to actions of Expectation 2. Decision-makers in the US evaluated how their actions would affect the position of the Soviet Union. In the National Security Council, for example, they feared that supporting Pakistan could cause India to move towards closer relations with the Soviet Union, strengthening the Soviet position in South Asia. These considerations fit the discussions of Expectation 1 and Expectation 2.

\subsubsection{The Soviet Mediation of India - Pakistan War of 1971}

In mediating the 1971 crisis, the Soviet Union overtly pursued a pro-Indian policy. It prioritized its geopolitical interests in the region and accused Pakistan for the crisis. It also openly supported East Pakistani independence and claimed that the source of the problem was coming from West Pakistani atrocities in East Pakistan. For example, then Soviet President Podgorny sent a message to the Pakistani President Yahya suggesting that the crisis in East Pakistan can only be solved by political means, and the use of force does not resolve the issue. However, Podgorny's point is neither a simple wish nor suggestion. By urging Pakistan to stop the bloodshed and repressions of the population in East Pakistan, the Soviet Union actually implied that West Pakistan was the aggressive party in the conflict and responsible for the atrocities. This position can be evidenced below:

"We consider it our duty to address you, Mr. President, on behalf of the Presidium of the Supreme Soviet of the USSR, with an insistent appeal for the adoption of the most urgent measures to stop the bloodshed and repressions against the population in East Pakistan and for turning to methods of a peaceful political settlement."214

\footnotetext{
${ }^{213}$ Washington Special Action Group Meeting, 8 December 1971 comp. by Rajendra Kumar Jain US - South Asian Relations 1947-1982 Vol.3, p. 44.

${ }^{214}$ Soviet Review 18 January 1972 Supplement, 8-9 comp. by Rajendra Kumar Jain Soviet-South Asian Relations 19471978 Volume 1. Soviet President Podgorny’s Message to President Yahya Khan of Pakistan, 2 April 1971, p. 105.
} 
The Soviet Union was also critical of outside intervention. The Soviets suspected that outside powers would use the crisis as an opportunity to gain geopolitical and ideological gains in South Asia. For example, in a speech made at a dinner given in honor of the King of Afghanistan, Podgorny stated that:

"Lately, there has been an aggravation of the situation in the Hindustan subcontinent. The problem of refugees from East Pakistan arose in connection with the known events there. Tension has grown in relations between the two biggest states of the area-India and Pakistan. There are forces who would not mind using the obtaining tense situation for attaining their unseemly aims and for whipping up armed clashes in that area."215

Most of the statements made in this period identify the pro-Indian stance of the Soviet Union. At a luncheon given in honor of the Indian Prime Minister Indira Gandhi, Kosygin stated that:

"We clearly comprehend the complexity of the questions that have emerged as a result of these events in the relations between India and Pakistan. It is impossible to justify the actions of the Pakistani authorities which have compelled millions of people to leave their country, land, property, and to seek refuge in the neighbouring India...At this crucial moment we address an appeal to President Yahya Khan to take the most effective steps for the liquidation of the hotbed of tension that has emerged." 216

In this speech, Kosygin clearly condemns Pakistani actions and makes an appeal to stop the atrocities in East Pakistan. In the TASS statement below, the Soviet Union showed its solidarity with India as well.

"On encountering the growing resistance of the East Pakistan population to the mass repressions and persecutions, the Government of Pakistan tried to put the blame for this situation on India and embarked on a course of aggravating relations with it."217

In the UN Security Council meetings, the Soviet Union continued to support India and accused the actions of Pakistan for instigating the crisis. For example, on 6 December 1971, the then Soviet Representative to the Security Council Yakov Malik said that:

"The main cause for the military conflict that has broken out on the territory of the Hindustan Peninsula is a certain series of actions of the Government of Pakistan which are directed at the suppression of the lawful demands and aspirations of the East Pakistan population... The military conflict in that region is the direct consequence of a series of acts of oppression, mass repression and violence conducted over a member of months with the use of the most modern forms of weapons and arms with a view to suppressing the clearly expressed will of 75 million East Pakistanis... We

\footnotetext{
${ }^{215}$ Ministry of External Affairs, Bangladesh Documents, Volume III, 160-1 comp. by Rajendra Kumar Jain Soviet-South Asian Relations 1947-1978 Volume 1. Podgorny`s Speech at a dinner in honour of the King of Afghanistan, 14 September 1971, pp. 121-122.

${ }^{216}$ Soviet Review 12 October 197134 comp. by Rajendra Kumar Jain Soviet-South Asian Relations 1947-1978 Volume 1, Document 49 (Extract) Kosygin's Speech at a Luncheon Given in Honour of Indian Prime Minister Indira Gandhi, 28 September 1971, p. 122.

217 Soviet Review 18 January 1972 Supplement, 12-3 comp. by Rajendra Kumar Jain Soviet-South Asian Relations 1947-1978 Volume 1 Document 56 TASS Statement, 5 December 1971, p. 133.
} 
appeal to the Government of Pakistan to take effective action towards a political settlement and immediately to recognize the will of the East Pakistan population. "218

One day later, Yakov Malik again declared in the UN General Assembly meeting on 7 December 1971 that the party actually responsible for the crisis was Pakistan. He stated that:

"The crux of the matter is that the bloody repression by Pakistani authorities of the 75 million-strong population of East Pakistan has led to the deaths of many thousands of peaceful people and the flight of almost 10 million refugees to the neighbouring country of India in order to save their lives. "219

In the same meeting, Malik also attributed the ineffectiveness of the UN Security Council to resolve the crisis to the power struggle between great powers. He said that:

"Two great powers, because of their political orientation and ideological conceptions and military-political commitments, proved unable to rise above their narrow, selfish considerations and aspirations. ${ }^{, 220}$

By "great powers" Malik refers to the US and China. Instead of mediating the crisis in a way that could immediately ease the conflict, he asserted that two great powers prioritized their own interests in the region. These competing interests in easing the crisis prevented the collaboration of the states.

In this period, there was also extreme tension between the Soviet Union and China. The Soviet Union criticized China's position and accused it pandering to the imperialist agenda. For example, in one of the speeches made by Malik in the UN Security Council on 13 December 1971, Malik said that:

"It is easy to see that the substance of the position of Peking lines in this: to inflame the Indo-Pakistan conflict, to pour oil on the fire and thus to strive to attain its expansionist, selfish, great-power chauvinist purposes... They view Pakistan simply as a spring-board and a puppet for their game that they are playing in this area of the world, as in the international arena as a whole. "221

Malik also asserted that China played the same geopolitical game that the imperialist powers had once played. He said in the same meeting that:

\footnotetext{
${ }^{218}$ UN Document S/PV 1608, 5-6 comp. Rajendra Kumar Jain Soviet-South Asian Relations 1947-1978 Volume 1 Statement by the Soviet Representative Malik in the Security Council, 6 December 1971 (Extracts), p. 141.

${ }^{219}$ UN Document A/PV2003 comp. Rajendra Kumar Jain Soviet-South Asian Relations 1947-1978 Volume 1 Statement by the Soviet Representative Malik in the UN General Assembly, 7 December 1971 (Extracts) Document 62, pp. 145149 .

${ }^{220}$ Ibid.

${ }^{221}$ UN Document S/PV 1613 comp. Rajendra Kumar Jain Soviet-South Asian Relations 1947-1978 Volume 1 Document. 64, pp. 149-155.
} 
"In actual practice, by provoking an aggravation of the crisis in East Pakistan and by inflaming the IndoPakistan conflict, the Maoists, in order to attain their great power purposes in South-East Asia, are, in fact, attempting to carry out a policy of setting Asians against Asians. "222

On 15 December 1971, in another statement made by Malik in a UN Security Council meeting, Malik's accusations of China that it was collaborating with the US became more clear. He asserted that:

"Peking is following exactly the same course as Washington, and in this area, as has already been noted, there is a United States-Chinese duet going on. Peking is not interested in the fate of millions of people who are undergoing unheard of sufferings. Peking is interested in only one thing: to exploit the situation and to strengthen its position in East Asia and in the Indian subcontinent... ,223

One week later on 21 December 1971, Malik made even more antagonistic statements against China in the UN Security Council. He asserted that:

"Only one permanent member of the Security Council, the Peking Government, has been blind and deaf to these tragedies and sufferings of so many millions of persons. It has given unreserved support to the tyranny, terrorism and violence and not condemned those who have perpetrated it, nor has there been any expression of regret about the victims on the part of Peking, on the part of the representative of China in the Security Council. ,224

The Soviet mediation of the 1971 war meets the criteria of Expectation 1. One can detect a competitive tone in the released statements. The Soviet Union blamed especially China and then the US for the atrocities in the region. The Soviet Union also discernibly demonstrated its position by articulating its firm support for India. Siding with one side of the conflict fits into the likely actions of Expectations 2 which is that each mediator state would support the state with which it has good relations.

\subsubsection{Chinese Mediation of the India - Pakistan War of 1971}

In this conflict, China pursued a pro-Pakistani policy. It criticized both superpowers. However, its frictions with the Soviet Union became more evident in this crisis. For example, an article released by the People's Daily stated that:

"It is worth noting that the two superpowers, working in close co-ordination with the Indian reactionaries, crudely interfere in the internal affairs of Pakistan. The US State Department issued a statement in an effort to poke its nose into Pakistan's internal affairs, while the Soviet Government acted more blatantly...The Chinese Government and

\footnotetext{
222 Ibid.

${ }^{223}$ UN Document S/PV 1615 comp. Rajendra Kumar Jain Soviet-South Asian Relations 1947-1978 Volume 1 Document 65 , pp. $155-158$.

${ }^{224}$ UN Document S/PV 1621 comp. Rajendra Kumar Jain Soviet-South Asian Relations 1947-1978 Volume 1 Statement by the Soviet Representative Malik in the Security Council, 21 December 1971 Document 70, pp. 162-166.
} 
people will, as always, resolutely support the Pakistan Government and people in their just struggle for safeguarding national independence and state sovereignty and against foreign aggression and inference. "225

In this statement, China criticized the position of the other superpowers. There were no incentive to engage in collaboration to ease the conflict. Each actor pursued its own interests in the region.

On 12 April 1971, the then Premier of China Zhou En-lai sent a message to the Pakistani President Yahya. He criticized the activities of the US and the Soviet Union. He added that China would help Pakistan in the case of a serious threat.

"We have noted that of late the Indian Government has been carrying out gross interference in the internal affairs of Pakistan by exploiting the internal problems of your country. And the Soviet Union and the United States are doing the same one after the other...Your Excellency may rest assured that should the Indian expansionists dare to launch aggression against Pakistan, the Chinese Government and people will, as always, firmly support the Pakistan Government and people in their just struggle to safeguard state sovereignty and national independence. ${ }^{, 226}$

The above statements exhibited an overt pro-Pakistani position of China.

At his speech at the banquet given in honour of the Pakistani delegation, the then Foreign Minister of China Chi Peng-fei also supported the Pakistani position. He pointed out that Pakistan had struggled hard to defend its territorial integrity and tried to protect its independence from foreign aggression. He stated that:

"In order to defend their state sovereignty, territorial integrity and national independence, they (the Pakistani people) have waged unremitting struggles against foreign aggressors, interventionists and domestic secessionists. The Pakistan Government has adhered to its foreign policy of independence and contributed to the defense of peace in Asia and the promotion of Afro-Asian solidarity "227

Fu Hao, the representative of the Chinese delegation to the UN, also highlighted that the uprisings in East Pakistan were part of the internal affairs of Pakistan and that other countries should not interfere.

"The Chinese Government and people have always held that the internal affairs of any country should be settled by the people of the country themselves. The question that has arisen in East Pakistan is purely Pakistan's internal affair which can only be settled by the Pakistan people themselves, and no country has the right to interfere in it under any pretext. ",228

\footnotetext{
${ }^{225}$ Peking Review, What Are Indian Expansionists Trying to Do? 16 April 1971 Vol.14 No.16 pp. 7-8 [online] Available at: https://www.marxists.org/subject/china/peking-review/1971/PR1971-16.pdf [Accessed 27.03.2017].

${ }^{226}$ Dawn, 13 April 1971 Chou En-lai's Message to Yahya Khan, 12 April 1971 comp. by Rajendra Kumar Jain (1981) China - South Asian Relations 1947-1980 Document 189, The Great Britain: The Harvester Press, John Spiers, p. 211.

${ }^{227}$ Peking Review Chi Peng-fei's Speech 12 November 1971 Vol. 14, No.46, p. 5 [online] Available at: https://www.marxists.org/subject/china/peking-review/1971/PR1971-46.pdf [Accessed 27.03.2017].

${ }^{228}$ Peking Review China's Stand on Question of Refugees from East Pakistan 26 November 1971 Vol. 14, No.48, p. 20
} 
Huang Hua, the Chinese representative to the UN Security Council, also accused the Soviet Union for supporting Indian atrocities. On 5 December 1971 in the UN Security Council meeting, he stated that:

“Over a long period the Soviet Government has energetically supported India's expansion and has provided the Indian expansionists with large quantities of arms and other war material. It has encouraged India in its scheming activities to subvert and dismember Pakistan, and has at the same time openly exerted all kinds of pressure on the Pakistan Government...In supporting India in its provoking of an armed conflict with Pakistan, the purpose of the Soviet Government is to take advantage of India's inevitable dependence on the Soviet Union in the war and to control the Indo-Pakistan subcontinent and the Indian Ocean and expand its spheres of influence so as to compete with another Super Power for world hegemony..., ,229

Chia Kuan-hua, the Chinese representative in the UN General Assembly, also declared that the tension in South Asia was a legacy of the colonial past.

"The dispute between India and Pakistan is a legacy of the British imperialist rule in the Indian subcontinent. The Chinese Government has consistently held that the new independent Afro-Asian countries should resolve their disputes in a friendly way through consultation on an equal basis. They must not be taken in by the imperialists. "230

On 9 December 1971, the Chinese Foreign Minister declared that:

"The Chinese Government and people sternly condemn the Indian Government for its criminal acts of expansionism and armed aggression and firmly oppose the power-politics and despotism practiced socialimperialism." 231

In this statement, he did not only condemn India, but also harshly criticized the Soviet Union. In another statement by Huang Hua, the clear pro-Pakistani stance of China can also be detected.

"No matter what happens in the India - Pakistan subcontinent, the Chinese Government and people will firmly support the Pakistan Government and people in their just struggle against foreign aggression and defense of national independence and unity. ${ }^{232}$

These statements above indicate that China pursued a pro-Pakistani policy based on power politics and prioritized geopolitical concerns in mediating the 1971 crisis. The elements of a collaborative behavior pattern with other mediating actors cannot be found. Chinese mediation of

[online] Available at: https://www.marxists.org/subject/china/peking-review/1971/PR1971-48.pdf [Accessed 27.03.2017].

229 UN Document S/PV 1607, Document 199. comp. by Rajendra Kumar Jain (1981) China - South Asian Relations 1947-1980. The Great Britain: The Harvester Press, John Spiers, p. 223.

${ }^{230}$ Peking Review, Condemning Soviet-Supported Indian Aggression Against Pakistan17 December 1971, Vol. 14, No.51, pp. 11-12 [online] Available at: https://www.marxists.org/subject/china/peking-review/1971/PR1971-51.pdf [Accessed 27.03.2017].

${ }^{231}$ Hsinhua (Xinhua) News Agency, Document 201, 9 December 1971 comp. Rajendra Kumar Jain (1981) China South Asian Relations 1947-1980. The Great Britain: The Harvester Press, John Spiers, pp. 229-230.

${ }^{232}$ UN Document S/PV 1615, Document 203, comp. by Rajendra Kumar Jain (1981) China - South Asian Relations 1947-1980. The Great Britain: The Harvester Press, John Spiers, pp. 230-232. 
the 1971 meets the criteria of Expectation 1. China blamed the actions of the US and the Soviet Union, discredited their mediation attempts, and warned that nothing good can come from their sides. It therefore competed with other major powers. In that respect, it fits to the likely actions of Expectation 1. China also strongly showed its pro-Pakistani position. Siding with the one party of the conflict fulfills the likely actions of Expectation 2.

Shortly, the US, the Soviet Union and China pursued competitive policies in the 1971 war, and each of them prioritized their own interests over efforts to end the war between India and Pakistan. Therefore, the behavior of the major powers fits Expectation 1. The US and China supported Pakistan, whereas the Soviet Union sided with India. This accords with actions mentioned in Expectation 2, which is that the mediator state supports the state with which it has good relations. The important context to consider is the US-China rapprochement. During the crisis, tensions between the Soviet Union and China bifurcated. The statements above clearly reflect this Soviet-Chinese rift, paving way for the further US-China rapprochement. This rapprochement clearly delineated which countries supported which side of the conflict, where Pakistan was supported by both the US and China, and India was supported by the Soviet Union. Due to the clear delineation, there was no need to move between different mediator states in the search for support. Therefore, Expectation 3 was not realized, which assumed that if the party of the conflict did not receive enough support from a mediator state, the party of the conflict might move between other mediator states. It was the case in the 1965 conflict which Pakistani President Ayup Khan tried to use relations with China in order to secure greater support from the US. In the 1971 war however, Pakistan facilitated communication between China and the US.

\subsection{The Second Group of Cases: Nuclear Phase}

\subsubsection{The Nuclearization of the Crisis}

The Indian nuclear program started with the endeavors of Homi Bhabba, who was known as the father of the Indian nuclear program. Bhabba had written a letter on 12 March 1944 to Sir Dorab of Tata Trust, a large philanthropic organization in India belonging to the Tata Group. He complained about the poor research conditions of applied research in India and requested an establishment of a research center. The Tata group supported Bhabba and established the Tata Institute of Fundamental Research, and Bhabba became its director. ${ }^{233}$ In short, the Indian nuclear program had started as a

\footnotetext{
${ }^{233}$ Wilson Center International History Declassified Letter from Homi Bhabba to Sir Dorab of Tata Trust March 12, 1944 History and Public Program Digital Archive, Institute for Defense Studies and Analyses (IDSA), Tata Institute of Fundamental Research, Homi Bhaba Papers, IDHA-HBP-12031944. Obtained and contributed by A. Vinod Kumar and the Institute for Defence Studies and Analyses. [online] Available at:

http://digitalarchive. wilsoncenter.org/document/114188.pdf?v=daacab5241a927c6df8822363469984b [Accessed 27.03.2017].
} 
research program without military aspect. However, it gained a military dimension after India lost the war against China in $1962 .{ }^{234}$ The trauma caused by losing the war in conjunction with the Chinese nuclear test in 1964 incited India to develop its own nuclear bomb. ${ }^{235}$

India tested its first nuclear bomb in 1974, which was called Smiling Buddha. Although Indira Gandhi explained that it was a peaceful nuclear test, the international community was afraid that an Indian bomb would cause Pakistan to develop its own nuclear bomb. A movement towards this direction had however actually started even before the Indian nuclear tests. Bhutto had already disclosed his intention of building nuclear weapons in an interview to Manchester Guardian in 1965. Bhutto stated that "If India becomes a nuclear state then Pakistan must build a nuclear weapon even if we have to eat grass." 236

Pakistan's loss of the 1971 war and the subsequent independence of Bangladesh accelerated the Pakistani endeavors to have nuclear weapons. President Bhutto invited renowned Pakistani nuclear scientists to a conference in Multan and declared his support for the nuclear program. ${ }^{237}$ The conference in Multan was a vital step leading to Pakistan's nuclear capability. ${ }^{238}$

Serious concerns in the US regarding Pakistani nuclear capability had already begun to develop by the end of the 1970s. A declassified Special National Intelligence Estimate report revealed that the US estimated already in 1975 that Pakistan could develop a nuclear device by $1978 .^{239}$ France was planning to build a nuclear reprocessing plant in Pakistan at that time, but the project was cancelled. The cancellation of this agreement deferred the estimations of the acquisition of Pakistani nuclear capability. In 1979, however, estimations became pessimistic again. A declassified document of the National Intelligence Officer for Nuclear Proliferation revealed that the US predicted that Pakistan might have succeeded in acquiring the main components for a gas centrifuge. The same report claimed that this development would enable Pakistan to produce enriched uranium in $1982 .{ }^{240}$ An

\footnotetext{
${ }^{234}$ Pillalamarri, A. (2015). India's Nuclear Weapons Program: 5 Things You Need to Know The National Interest 22 April 2015 [online] Available at: http://nationalinterest.org/feature/indias-nuclear-weapons-program-5-things-you-needknow-12697 [Accessed 27.03.2017].

${ }^{235}$ Khan, F. H. (2012). Eating Grass: The Making of the Pakistani Bomb. Stanford, California: Stanford University Press, p. 6.

${ }^{236}$ Keatley, Patrick (1965). The Brown Bomb, Manchester Guardian 11 March 1965 cited in John L. Espesito, Tamara Sonn, and John O. Voll. (2016). Islam and Democracy After the Arab Spring. New York: Oxford University Press, p. 86. ${ }^{237}$ Khan, F. H. (2012). Eating Grass: The Making of the Pakistani Bomb. Stanford, California: Stanford University Press pp. 84- 88 .

${ }^{238}$ Weissman, S. and Krosney, H. (1981). The Islamic Bomb: The Nuclear Threat to Israel and the Middle East. New York: Times Books, p. 46.

${ }^{239}$ CIA Electronic Reading Room, Memorandum to Holders, Special National Intelligence Estimate, Prospects for Further Proliferation of Nuclear Weapons, SNIE 4-1-74, 18 December 1975, Secret Excised Copy, p. 8 [online] Available at: http://www.foia.cia.gov/sites/default/files/document_conversions/89801/DOC_0001247369.pdf [Accessed 27.03.2017].

${ }^{240}$ The National Security Archive The George Washington University (hereafter NSARCHIVE), Memorandum for Interagency Intelligence Working Group on Nuclear Proliferation from John Despres National Intelligence Officer Monthly Warning Report 18 January 1979, Top Secret, excised copy Source: CREST from National Security Archive, p.2 [online] Available at: http://nsarchive.gwu.edu/nukevault/ebb333/doc22.pdf [Accessed 27.03.2017].
} 
interagency working group paper on South Asian nuclear and security problems also estimated that sufficient highly enriched uranium for a weapon could be available by 1983. A nuclear test was then more likely to occur in $1984 .^{241}$

The US feared that a nuclear Pakistan would cause India to develop its nuclear program further. This concern paved way for international collaboration to stop the nuclearization of Pakistan. The then US Assistant Secretary of State for Near East Affairs Harold H. Saunders and the Assistant Secretary of State for Oceans and International Environmental and Scientific Affairs Thomas R. Pickering gave a briefing to the Under Secretary of State for Political Affairs David D. Newsom on 20 January 1979. In this briefing, Saunders and Pickering recommended that there should be a common understanding between the West and China concerning nuclear proliferation in South Asia. It was pointed out that China had influence on Pakistan. For this reason, an approach to Chinese leader Deng Xiaoping was offered. It was also highlighted that the Soviet Union shared the same non-proliferation concerns with the US and did not want to witness a nuclear arms race in South Asia. Thus, contact with Dobrynin, the Soviet Ambassador to the US, was also recommended for the transmittal of the message that a Russian demarche to Pakistan is welcome by the US. ${ }^{242}$ Although the option of contacting Dobrynin was abandoned at the Policy Review Committee held on 22 January $1970^{243}$, a comprehensive diplomatic campaign including China, Saudi Arabia, and some European states was recommended. ${ }^{244}$ This is a crucial recommendation which shows that crises with a nuclear dimension brings diverse actors to the negotiation table. The Special Representative of the President for Non-Proliferation Matters Gerard C. Smith also highlighted the importance of an international approach. He claimed that a nuclear Pakistan was the biggest challenge to the international structure since 1945. He argued that Germany, Japan and the Soviet Union would also join the international effort because they share the same interest in limiting the proliferation of nuclear weapons. Smith claimed that efforts at the UN level would be required. ${ }^{245}$ This recommendation

\footnotetext{
${ }^{241}$ NSARCHIVE, Action Memorandum From Anthony Lake, Harold H. Saunders and Thomas R. Pickering to the Deputy Secretary of Department of State PRC Paper on South Asia enclosing Interagency Working Group Paper "South Asian Nuclear and Security Problems“, Analysis of Possible Elements in a U.S. Strategy, 23 March 1979. [online] Available at: http://nsarchive.gwu.edu/nukevault/ebb333/doc32a.pdf p. TAB A [Accessed 27/03/2017].

${ }^{242}$ NSARCHIVE, Herald H. Saunders and Thomas R. Pickering The Memorandum of a Briefing to David D. Newsom Mini Policy Review Committee Meeting on the Pakistan Nuclear Program. 20 January 1979. p.3, Source: [online] Available at: http://nsarchive.gwu.edu/nukevault/ebb333/doc23a.pdf [Accessed 27.03.2017].

${ }^{243}$ NSARCHIVE, University Marshall Shulman, Paul Kreisberg, and Robert Barry to David D. Newsom Mini Policy Review Committee Meeting on Pakistani Nuclear Intentions, 22 January 1979 Source, [online] Available at: http://nsarchive.gwu.edu/nukevault/ebb333/doc23b.pdf [Accessed 27.03.2017].

${ }^{244}$ NSARCHIVE, The Memorandum of The Policy Review Committee Meeting on 22 January 1979 p. 2. Source: [online] Available at: http://nsarchive.gwu.edu/nukevault/ebb333/doc23c.pdf [Accessed 27.03.2017].

${ }^{245}$ NSARCHIVE, Memorandum from Gerard C. Smith, Special Representative of the President for Non-Proliferation Matters, to the Deputy Secretary, 27 March 1979, pp. 1-2. [online] Available at: http://nsarchive.gwu.edu/nukevault/ebb333/doc32c.pdf [Accessed 27.03.2017].
} 
exhibits the burgeoning emphasis on collaboration at the international level concerning the crises in South Asia.

The US further highlighted the importance of international mediation, while recognizing the limits of collaboration. It offered that the mediation option should not be limited only to a group of states or to an international organization. One should also consider the possibility of a diplomatic mission by highly respected individuals who hold international recognition. ${ }^{246}$

The US concern steadily increased. In a telegram from the US Embassy in India to the US Department of State, Ambassador Goheen reported that India considered the nuclearization of Pakistan as very serious, and even the moderate Indian Prime Minister Dessai declared that if India detect a nuclear test, they would then destroy the nuclear capabilities of Pakistan. ${ }^{247}$

Although India was not receptive to an international solution or Chinese involvement, the US was convinced that an international solution was necessary to stop the further nuclearization of South Asia. In this respect, the US considered communicating with China in order to secure formal assurances that China would not deploy its nuclear forces against India. ${ }^{248}$ The US Department of State instructed the US Ambassador to China Leonard Woodcock to contact Chinese officials and to convey to them US concerns regarding the nuclearization of South Asia. Further instructions were to hear Chinese suggestions to this problem and convey that nuclearization of Pakistan would not only be a problem to the US, but would create major problems to other nations as well. The State Department also informed the US ambassador Woodcock that there was already a meeting between Deputy Secretary of State Warren Christopher and the Chinese ambassador to the US Chai Zemin as an effort to reach a regional solution to the nuclearization of Pakistan. ${ }^{249}$

Another example of increasing collaboration is the briefing given during the Policy Review Committee meeting to the then Secretary of State Cyrus Vance on 10 November 1979. It was recommended in this meeting that the US should have continued to consult with Europeans and should have enlarged its diplomatic efforts to include Japan. This broad coalition should have been

\footnotetext{
${ }^{246}$ NSARCHIVE, Paul H. Kreisberg, Policy Planning Staff through David Newsom to the Deputy Secretary, "A Mediator for the South Asian Nuclear Program 22 May 1979. Source: RG. 59 Records of Anthony Lake, box 5, 5/1631/79. [online] Available at: http://nsarchive.gwu.edu/nukevault/ebb333/doc34a.pdf [Accessed 27.03.2017].

${ }^{247}$ NSARCHIVE, A telegram from the US Embassy in New Delhi to State Department cable 9979 "India and the Pakistan Nuclear Program 7 June 1970 Source: MDR Release taken from [online] Available at: http://nsarchive.gwu.edu/nukevault/ebb333/doc35b.pdf [Accessed 27/03/2017].

${ }^{248}$ Wilson Center International History Declassified US Department of State Cable 145139 to US Embassy India [Repeating Cable Sent to Embassy Pakistan], ' Non-Proliferation in South [Asia] 06 June 1979, pg. 6 [online] Available at: http://digitalarchive.wilsoncenter.org/document/114198.pdf?v=50d4fa5adf1b76ec1f393398bc70a7c5 [Accessed 27/03/2017].

${ }^{249}$ NSARCHIVE, A Telegram from the State Department to US Embassy, Beijing, „, South Asia Nuclear Problem: Exploratory Discussion with the PRC, 20 June 1979, pp. 1-2., excised copy cable 158902 Source: FOIA Request taken from [online] Available at: http://nsarchive.gwu.edu/nukevault/ebb333/doc38.pdf [Accessed 27.03.2017].
} 
used to place pressure on Pakistan in nuclear issues. ${ }^{250}$ The developments above exhibit the first signs of collaboration attempts between international actors brought about by concerns of Pakistani nuclearization.

The danger emanating from a Pakistani nuclear test and its subsequent consequences for South Asian security made the nuclearization of the crisis more poignant in the 1980s. For example, the US Department of State Bureau of Intelligence and Research released a report on 25 June 1981, highlighting the possibility of a Pakistani nuclear test and the risk of the aftermath of nuclear weaponization. India's possible reactions to a Pakistani nuclear test were also discussed.

"India fears that Pakistan might launch an attack against it with the expectation that the international community will call for a ceasefire and thus force the contentious issue of Kashmir into the international arena. Indian counterattack would almost certainly involve efforts to destroy Pakistan's nuclear facilities. India would undoubtedly ignore any international resolution concerning Kashmir. India under such circumstances might even decide to eliminate the threat of a nuclear-armed Pakistan once and for all by a counterattack aimed at the destruction of Pakistan. ${ }^{, 251}$

These intelligence estimates reflect the serious concerns of the US Department of State stemming from potential nuclear tests of Pakistan. The US Department of State emphasized that after Pakistan conducts nuclear tests, it would pursue belligerent policies against India regarding Kashmir on the expectation that the international community would intervene. The report also highlights that India would likely respond harshly to these Pakistani activities.

For example, another report on 09 April 1981 to the Reagan Administration by the National Foreign Assessment Center (NFAC) and the CIA asserted that:

"The heightened tension resulting from the presence of Indian and Pakistani nuclear explosives could spur a greater conventional arms buildup, and perhaps a race for weaponization. There would be a risk that a future IndoPakistani conflict could result in the use of nuclear weapons. "252

\footnotetext{
${ }^{250}$ NSARCHIVE, Assistant Secretaries Harold Saunders, Thomas Pickering, and Anthony Lake through Mr. Christopher, Mr. Newsom, and Mrs. Benson to the Secretary, „November 14 PRC Meeting on South Asian Nuclear Issues“10 November 1979 Source: RG 59, Records of Anthony Lake, box, TL 11/1 - 11/15/70 taken from [online] Available at: http://nsarchive.gwu.edu/nukevault/ebb333/doc44.pdf , p. 6 [Accessed 27.03.2017].

${ }^{251}$ Wilson Center, Bureau of Intelligence and Research, US Department of State, 'India-Pakistani Views on a Nuclear Weapons Option and Potential Repercussions', 25 June 1981, History and Public Policy Program Digital Archive, Department of State FOIA release, copy courtesy of Jeffrey Richelsen. Obtained and Contributed by William Burr and included in NPIHP Research Update p. 6. [online] Available at: http://digitalarchive.wilsoncenter.org/document/114242 [Accessed 27.03.2017].

${ }_{252}$ Wilson Center, Special Assistant for NPI, NFAC, CIA, to Resource Management Staff, Office of Program Assessment et al, 'Request for Review of Draft Paper on the Security Dimension of Non-Proliferation` 09 April 1981, History and Public Policy Program Digital Archive, Mandatory Declassification Review Request. Obtained and contributed by William Burr and included in NPIHP Research Update Number 6 p. 19 [online] Available at: http://digitalarchive.wilsoncenter.org/document/114233 [Accessed 27.03.2017].
} 
This report shows that already in 1981, the US had concerns about Pakistani nuclear tests that could trigger a wider conflict with a nuclear dimension.

The concern increased in the 1990s when India showed signs of testing its nuclear capability a second time. It was believed that if India tests its nuclear weapons again, it would lead to an overt demonstration of Pakistani nuclear capability through a number of nuclear explosions. Another telegram in 1995 sent by the US Department of State to the US Embassy in China also demonstrates US collaboration with China regarding the nuclear tests in South Asia. ${ }^{253}$ In this telegram, the US mentioned an article written by Tim Weiner in New York Times. ${ }^{254}$ In this article, Weiner claimed that spy satellites detected some activity at the Pokaran test site in India and American officials believed that India was preparing to test its nuclear capability for the first time since 1974. The US was concerned that the claims in this article would trigger Pakistan to follow the same path leading to nuclear explosion. This telegram articulated this danger to Chinese authorities and required them to warn Pakistani authorities not to follow suit even if India conducted nuclear tests.

Despite these fears, Pakistan did not detonate a nuclear explosion until 1998. However, India decided to conduct a nuclear test in 1998, 24 years after its first tests in 1974. This Indian decision compelled the Pakistani Prime Minister Nawaz Sharif to conduct nuclear tests as well. The US intervened and tried to stop Pakistan. US President Bill Clinton telephoned Sharif and urged him not to follow the same suit with India. The US also tried to persuade Pakistan through some incentives such as the cancellation of the Pressler amendment ${ }^{255}$, resuming economic assistance, and reviving of military relationships. ${ }^{256}$ These incentives did not stop Pakistan because the pressure coming from Indian nuclear tests were bigger than the US incentives. For this reason, Pakistan also detonated five nuclear explosions on 28 May 1998, their first tests. These tests completed the phase of overt nuclearization in South Asia.

\footnotetext{
${ }^{253}$ Wilson Center, Draft State Department Telgram to US Embassy Beijing, ' Possible Indian Nuclear Test' ,, December 15, 1995, History and Public Policy Program Digital Archive, Mandatory Declassification Review request. Obtained and contributed by William Burr and included in NPIHP Research Update number 10. [online] Available at: http://digitalarchive.wilsoncenter.org/document/116342 [Accessed 27.03.2017].

${ }^{254}$ Weiner, T. (1995). U.S. Suspects India Prepares To Conduct Nuclear Tests. The New York Times, 15 December 1995 [online] Available at: http://www.nytimes.com/1995/12/15/world/us-suspects-india-prepares-to-conduct-nuclear-test.html [Accessed 27/03/2017].

${ }^{255}$ The Pressler amendment forbids the military and economic assistance to Pakistan, if the US president could not assure that Pakistan does not have nuclear explosive device. Senator Larry Pressler sponsored the amendment. It was passed in the US Congress on August 1985.

${ }^{256}$ Association for Diplomatic Studies and Training India and Pakistan on the Brink: The 1998 Nuclear Tests Moments in the U.S. Diplomatic History [online] Available at: http://adst.org/2014/07/india-and-pakistan-on-the-brink-the-1998nuclear-tests/ [Accessed 23.03.2017].
} 


\subsubsection{The Crises at the Beginning of 1980s and Kahuta Crisis}

As described in the Introduction, a crisis has a nuclear dimension if one part of the conflict has nuclear capabilities. Although Pakistan conducted its first nuclear test in 1998, the international community believed that Pakistan already acquired nuclear capability in the mid 1980s, while India conducted its first nuclear test in 1974. For my analysis, I use 1974 as the year in which the crises between India and Pakistan gained a nuclear dimension. Therefore, the crises that occurred in the beginning of the 1980s also had a nuclear dimension, albeit not at the same level as in the 1990s. I use the crises in the 1980s as one analytical unit and analyzed the mediation of major powers to these crises not separately, but jointly.

Despite the concerns at the international level, Indo-Pakistani relations were strong in the beginning of the 1980s. In early 1982, there were even discussions on a no-war pact. Pakistan submitted a draft agreement on nonaggression in June 1982. In return, India proposed to create an Indo-Pakistan joint commission. ${ }^{257}$ Consequently, the Pakistani President Zia and the Indian Prime Minister Indira Gandhi met at a bilateral summit in New Delhi on 1 November 1982. They decided to create a joint commission to solve the problems of two countries through dialogue. ${ }^{258}$ However, an article released by the Washington Post on 20 December 1982 abruptly interrupted these positive developments. This article reported leaked US intelligence sources which claimed that India was considering launching a preemptive air strike on nuclear facilities in Pakistan. The report highlighted India's concerns about the construction of the new nuclear laboratory next to the Pakistan Institute for Nuclear Science and Technology in Nilore. According to the same report, the US and India feared that the spent fuel in the Karachi Nuclear Power Plant (KANUPP) could be diverted to this new laboratory for reprocessing. Moreover, the report stated that KANUPP could have produced 10 to 20 kilograms of weapons grade plutonium which equals one to three Hiroshima-sized weapons. ${ }^{259}$ These developments caused India to consider contingency plans. If the claims in the report were true, the planning phase of the preemptive attack would have occurred at the same time that India and Pakistan were meeting to establish the above-mentioned joint commission. Upon learning this, Pakistan was astonished.

\footnotetext{
${ }^{257}$ Dixit, J. N. (1996). Anatomy of a Flawed Inheritance: Indo - Pak relations 1970-1994. India: Konark Publishers, p. 72.

${ }^{258}$ Perkovich, G. (1999). India's Nuclear Bomb: The Impact on Global Proliferation. Berkeley and Los Angeles. California: The University of California Press, p. 239.

${ }^{259}$ Benjamin, M.R. (1982). India Said to Eye Raid on Pakistani A - Plants. The Washington Post, 20 December 1982 contributed by William Claiborne [online] Available at:

https://www.washingtonpost.com/archive/politics/1982/12/20/india-said-to-eye-raid-on-pakistani-a-plants/7e30dde5-

e97c-45dc-82bb-521dee37a6ac/ [Accessed 27.03.2017].
} 
India rejected the allegations and labelled the report as an attempt to impair the recent reconciliation between India and Pakistan. ${ }^{260}$ The report also stated that K.R. Narayanan, India's ambassador to Washington, rejected all claims by US intelligence sources and asserted that there was no Indian contingency plan to attack the Pakistani nuclear facilities. ${ }^{261}$ Regardless of the authenticity of India's contingency plans, US intelligence sources as to the existence of contingency plans exhibited that the US was paying attention to the conflict and its nuclear dimension.

In the end, the preemptive attack was not carried out. Nevertheless, some studies claimed that India might have at least evaluated the preemptive attack as an option. W.P.S. Sidhu interviewed a former Indian air force director of operations. This interview revealed India's position that a preemptive attack could have destroyed the Kahuta nuclear facility. The real concern, according to the interview, was not the success of the operation itself. It was rather a possible allout war between India and Pakistan following the preemptive attack. ${ }^{262}$ However, this explanation is not sufficient to elucidate the Indian inaction. If fear of all-out war was the only reason hindering the preemptive attack, then why India did not hesitate to launch an all-out war in the preceding crises. To address this, Perkovich attempted clarify the matter with an interview with a former defense analyst. According to Perkovich's statement, the former defense analyst claimed that India did not launch preemptive attacks because it would lose 50 percent of the Jaguar fighting planes recently acquired at that time. ${ }^{263}$ This evidence is also not persuasive. If Pakistan were at the threshold of becoming a nuclear power, then India would have to live with a nuclear Pakistan forever. Therefore, losing the 50 percent of the Jaguar fighter jets would not be a reasonably decisive factor to avoid a preemptive strike.

Other interviews conducted by Perkovich with three former high ranking air force and Ministry of Defense officials further explain the situation. Based on these interviews, Perkovich claimed that Pakistan would have started a major war and attacked India's nuclear reactors and reprocessing plants, if India had launched a preemptive attack. ${ }^{264}$ This was a specific threat against India and a more persuasive argument. Perkovich also supports his claim by citing the meeting between Munir A. Khan, the Chairman of the Pakistan Atomic Energy Commission, and Raja Rammana, the Chairman of Bhabha Atomic Research Center, in Vienna in 1983. Munir A. Khan recounted Perkovich that Munir A. Khan transmitted the message to Indian side in Vienna meeting

\footnotetext{
${ }^{260}$ India News Press Report on Alleged Indian Military Plans - ` Figment of Imagination ` - Envoy, 27 December 1982 p.1 cited from Perkovich, G. (1999). India's Nuclear Bomb, p. 240.

${ }^{261}$ Benjamin, M.R. (1982).India Said to Eye Raid on Pakistani A - Plants. The Washington Post, 20 December 1982. contributed by William Claiborne.

${ }^{262}$ Sidhu, W.P.S. The development of an Indian nuclear doctrine since 1980 p. 331 cited from Perkovich, G. (1999). India's Nuclear Bomb, p. 240.

${ }^{263}$ Ibid.

${ }^{264}$ Ibid. pp. 240-241.
} 
that "if Kahuta were attacked, the uranium fallout would be less toxic because Pakistan had only a small enrichment plant for plutonium. However, after such an attack, Pakistan would assume that the attack came from India and would respond accordingly." 265 This meeting allowed India to see the dangerous consequences of a preemptive attack, perhaps encouraging a decisive end to the crisis.

The crisis in 1982 ended without escalation. However, the allegations of common Indian and Israeli operation on Pakistani nuclear facilities started again in 1984. The New York Times reported that CIA officials briefed members of the Senate Select Committee on Intelligence in September 1984. CIA officials told the Committee members that aides of Indira Gandhi recommended attacking the Kahuta enrichment facility in Pakistan. ${ }^{266}$ Another declassified document, a memorandum prepared for the then Director and Deputy Director of the CIA, also revealed US concerns about this matter. The US believed that a preemptive attack by India in the near term was a real possibility. The report also predicted that an Indian attack on nuclear facilities in Pakistan would prompt retaliatory attacks against Indian nuclear facilities and would lead to full-scale war. ${ }^{267}$ This reveals the US belief that deterrence between India and Pakistan based on the threat of attacking each other's nuclear facilities was not sustainable and that the crisis could easily escalate to a nuclear level. These US concerns also caused a concern in Pakistan which led Pakistan to solicit additional security guarantees from the US. On 5 October 1984, a Pakistani newspaper Nawa-e-Waqt published an article which claimed that Reagan offered Pakistan a NATO nuclear umbrella in exchange for Pakistan's abandonment of its nuclear weapons program. ${ }^{268}$ On 10 October, moreover, the US Ambassador to Pakistan Deane Hinton stated in Lahore that the US would react in case of an attack by India. ${ }^{269}$ US support led Indira Gandhi to terminate any kind of operation against the Kahuta nuclear facility in Pakistan, and the crisis ended. ${ }^{270}$

\footnotetext{
${ }^{265}$ Perkovich, G. (1999). India's Nuclear Bomb, p. 241.

266 Taubman, P. (1984). Worsening India-Pakistan Ties Worry U.S. The New York Times, 15 September 1984 [online] Available at: http:/www.nytimes.com/1984/09/15/world/worsening-india-pakistan-ties-worry-us.html [Accessed 27.03.2017].

${ }^{267}$ NSARCHIVE, Memorandum for Director and Deputy Director of Central Intelligence Agency from National Intelligence Officer for Warning David Y. McManis Monthly Warning and Forecast Meetings for July 1984 [online] Available at:

http://nsarchive.gwu.edu/nukevault/ebb531-U.S.-Pakistan-Nuclear-Relations,-1984-1985/documents/doc\%203\%208-684\%20cia\%20warning.pdf [Accessed 27.03.2017].

${ }^{268}$ Nawa-e-Wagt, 5 October 1984, translated in U.S. Embassy (Islamabad) to Secretary of State, cable no.080951Z, October 1984, p.2, in FOIA files Pakistan, National Security Archive, Washington, D.C. cited from Perkovich, G. (1999). India's Nuclear Bomb, p. 258.

${ }^{269}$ Pakistan National Security Archive, A Telegram in from the US Embassy in Islamabad to Secretary of State cable no. 120926Z, October 1984, p. 2 in FOIA files, Washington DC, cited from Perkovich, G. (1999). India's Nuclear Bomb p. 258. Perkovich says Hinton's comment was cited in this telegram.

${ }^{270}$ Levy, A. and Scott-Clark, C. (2007). Deception: Pakistan, the United States and the Global Nuclear Weapons Conspiracy. Great Britain: Atlantic Books, Grove Atlantic Ltd., p. 111.
} 


\subsubsection{The Brasstacks Crisis}

The Brasstacks crisis started because of a military exercise conducted by India. The Brasstacks exercise had four phases. The Phases I, II, and III were conducted from July until December 1986. They were exercises on the map and the telecommunications network was also tested. $^{271}$ These first three phases did not receive attention from either the Indian or Pakistani public. The problems began with Phase IV. It started after India deployed its military units near the India - Pakistan border. It was a large military exercise relative to NATO exercises. Both the scope and the place of the exercise (in the Rajasthan desert) were alarming for Pakistan. A large military exercise in the Rajasthan region would give India an opportunity to cut Pakistan in half, if India decided to make a surprise attack. ${ }^{272}$

The Pakistani media reaction to the exercise was one of alarm. The Urdu daily Jang reported that the Brasstacks exercise was the biggest exercise that India has ever held. It thought that the exercise was intended to convey a message to Pakistan that India was aware of Pakistani covert support to Sikh separatist groups in the Punjab region of India and would not tolerate Pakistani actions. ${ }^{273}$ The Sikh insurgency was a vital national security issue for India. ${ }^{274}$ The exercise received even more coverage in the Indian media after the cancellation of mail and passenger trains between Srinagar and Punjab and Haryana regions. ${ }^{275}$

Political leaders also started to express their concerns about the military exercises. Pakistani Senator Qazi Hussain Ahmed advised that Indian actions in the Rajasthan region should be carefully observed. ${ }^{276}$ Pakistani Foreign Secretary Abdul Sattar expressed Pakistan's apprehension over the Brasstacks exercisis at the South Asian Association for Regional Cooperation (SAARC) meeting in mid-November. Pakistani Prime Minister Mohammad Khan Junejo also raised the issue with his Indian counterpart Rajiv Gandhi, and Gandhi assured Junejo that it was only a routine

\footnotetext{
${ }^{271}$ Manoj Joshi, "From Maps to Field" The Hindu 29 March 1987 cited in Bajpai, K.P., Chari, P.R., Cheema, P.I., Cohen, S.P., Ganguly, S. (1997). Brasstacks and Beyond: Perception and Management of Crisis in South Asia. New Delhi: Ajay Kumar Jain Manohar Publishers \& Distributers, p. 157.

${ }^{272}$ Hersh, S. M. (1993). On the Nuclear Edge. The New Yorker, 29 March 1993 [online] Available at: http://www.newyorker.com/magazine/1993/03/29/on-the-nuclear-edge [Accessed 29.03.2017].

273 Public Opinion Trends, Vol. XIV, No. 188, 13 October 1986 cited in Bajpai K.P. et al. (1997). Brasstacks and Beyond, p. 158 and also look at Ganguly, S. (2008). Nuclear Stability in South Asia. International Security, Vol. 33, No. 2 Fall 2008, p. 51.

${ }^{274}$ Sikhs live mainly in Punjab region of India. They have a distinct language and religion which is called Sikhism. They felt increasingly discriminated since 1950s when only Hindi became the official language of India. They made several uprisings in the Punjab region of India in order to get more rights. Some fractions of the movement even demanded an independent state which is called Khalistan. India believed that Pakistan gave logistic support to Sikh militants and also trained them.

${ }^{275}$ The Times of India "Many Express, Main Trains Cancelled.” 10 November 1986 cited in Bajpai K.P. et al. (1997). Brasstacks and Beyond, p. 160.

${ }^{276}$ Dawn, 4 November 1986 cited in Bajpai K.P. et al. (1997). Brasstacks and Beyond, p. 159.
} 
exercise. ${ }^{277}$ On 2 December 1986, Pakistani Prime Minister Junejo expressed Pakistan's willingness to settle the crisis, albeit in a covertly threatening way. Junejo said that he could meet with Rajiv Gandhi to settle the crisis, but added that, Pakistan would react if India kept large amounts of its troops near to border. ${ }^{278}$

The anxiety spread by the scale of the Brasstacks exercise led Pakistan to extend its own military exercises. Pakistan was conducting its own military exercises at that time: Saf-e-Shikan and Flying Horse. The Saf-e-Shikan military exercise included the southern strike force reserve of the Pakistani army and was located in the Bahwalpur-Marot area. This region is located opposite the Rajasthan region in India. ${ }^{279}$ The exercise was supposed to end at first week of November 1986, but was extended due to Indian military deployments near the border. The exercise Flying Horse was being conducted in the Ravi - Chenab sector and was supposed to end the first week of December 1986. Pakistan extended this military exercise as well and redeployed its troops to the Shakargarh bulge area. This was a critical decision because the Shakargarh bulge area is closer to the IndianPakistani border than the Ravi - Chenab sector. This development was disconcerting to India because it revealed Pakistan's plans to block the roads and isolate Kashmir and Punjab from the rest of India in case of a military conflict. ${ }^{280}$

India was also alarmed by the observation that Pakistan placed mines along the border, gave its troops advance supplies of ammunition and kept its air force and satellite base at full working condition. ${ }^{281}$ Moreover, the Pakistani troops in the southern reserve did not stay in Bahwalpur. They crossed the Lodhran Bridge over the Sutlej River and took up positions at the opposite side of the Indian cities of Bhatinda and Ferozepur. ${ }^{282}$ These moves demonstrated Pakistani responses to a potential Indian aggression near to border in the Rajasthan region. The crisis intensified on 23 January 1987 when the Indian Ministry of Defense announced that Indian troops also moved forward to the Punjab state as a response to the frontline positions of Pakistan. ${ }^{283}$

\footnotetext{
${ }^{277}$ Bobb, D. and Badhwar, I. (1987). Back from the Edge. India, Pakistan hold marathon talks in New Delhi to defuse border crisis. India Today, 28 February 1987 [online] Available at: http://indiatoday.intoday.in/story/india-pakistan-holdmarathon-talks-in-new-delhi-to-defuse-border-crisis/1/336739.html [Accessed 27.03.2017].

${ }^{278}$ The Times of India, Junejo for Talks With India at All Levels 3 December 1986 cited in Bajpai K.P. et al. (1997). Brasstacks and Beyond, p. 164.

279 Bobb, D. and Badhwar, I. (1987). Game of Brinkmanship. India Today, 15 February 1987 [online] Available at: https://www.indiatoday.in/magazine/cover-story/story/19870215-game-of-brinkmanship-756869-1987-02-15 [Accessed 27.03.2017].

${ }^{280}$ Ibid.

281 Ibid.

282 Ibid. and The Hindustan Times (1987). Army Takes Up Positions along Punjab Border: Pak Warned Against Confrontation", 24 January 1987 cited in Bajpai K.P. et al. (1997). Brasstacks and Beyond, p. 167.

${ }^{283}$ Landay, J.S. (1987). India and Pakistan Continue Talks on Border Tensions. United Press International, 3 February 1987 [online] Available at: http://www.upi.com/Archives/1987/02/03/India-and-Pakistan-continue-talks-on-bordertensions/1058539326800/ [Accessed 27.03.2017].
} 
The military hotline facilitating the direct communication between the Director-General of Military Operations (DGMO) of both India and Pakistan was not used from 8 December 1986 until 23 January 1987. The military hotline was considered as an important element of confidence building measures. Not using it was a disappointment. ${ }^{284}$ Instead of using the military hotline, politicians chose to communicate through interviews and press conferences, which in return increased the tension. For example, Rajiv Gandhi asserted in a press conference that India could deal with all difficulties caused by the redeployments of Pakistani military units near the border. He declared that "India will not be pushed around.",285

Along the official channel, India's High Commissioner to Islamabad SK Singh was summoned to the Pakistani foreign office and was allegedly told by Pakistan's Minister of State for Foreign Affairs Zain Noorani that if India took any action not conducive to the sovereignty and territorial integrity of Pakistan, Islamabad will consider inflicting "unacceptable damage on India." Noorani further warned that Pakistan's actions would not be restricted to northern India, but would include targets in other regions. In response to Singh's query as to whether the message implied a threat to Bombay ${ }^{286}$, Noorani replied, "it might be so."287

President Zia suggested meeting with Rajiv Gandhi for a summit over a cricket game in order to decrease the tension. ${ }^{288}$ However, the crisis was still far away from defusing. Indian and Pakistani troops exchanged fire in Kashmir on 28 January $1987 .{ }^{289}$ Despite these negative developments, the Foreign Secretary of Pakistan Abdul Sattar arrived in New Delhi to hold talks with his Indian counterpart A.S. Gonsalves on 30 January $1987 .{ }^{290}$ The first day of talks were disturbed by developments along the border. It was reported that Pakistani troops were seen in the Chamb-Chicken's Neck in the Jauiran sector at night. ${ }^{291}$ It was also reported that there were an exchange of fire in the Mendhar and Poonch areas of Indian administered Jammu and Kashmir. Some villages were evacuated on both sides of the border in the Chamb sector. This claim was later

\footnotetext{
${ }^{284}$ Bobb, D. and Badhwar, I. (1987) Back From the Edge. India, Pakistan hold marathon talks in New Delhi to defuse border crisis. India Today, 28 February 1987.

${ }^{285}$ IPS - Inter Press Service India: We Will Not Be Pushed Around, Says Gandhi. 20 January 1987, New Delhi in NEXUS

${ }^{286}$ Bombay was the official name of Mumbai until 1995.

287 The Kargil Review Committee (2000). From Surprise to Reckoning: The Kargil Review Committee Report, New Delhi: SAGE Publications, p. 191.

${ }^{288}$ Sydney Morning Herald (Australia) (1987). Pakistan and India to Try Cricket Diplomacy. 31 January 1987, Saturday Late Edition, Source: Reuter Section: News and Features: pg. 20 NEXIS.

${ }^{289}$ United Press International (1987). Shooting Incidents Reported. 28 January 1987 [online] Available at: http://www.upi.com/Archives/1987/01/28/Shooting-incidents-reported/9357538808400/ [Accessed 27.03.2017].

290 United Press International (1987). India, Pakistan Begin Talks on Border Tensions. 30 January 1987 [online] Available at: http://www.upi.com/Archives/1987/01/30/India-Pakistan-begin-talks-on-border-tensions/6509368812046/ [Accessed 27.03.2017].

${ }^{291}$ The Chicken's Neck is a strategic place between Indian and Pakistan territory near to Indian state of Jammu and Kashmir.
} 
denied by Pakistan. ${ }^{292}$ On the fifth day of the talks, both countries finally reached an agreement. They agreed not to attack each other and agreed on the phased withdrawal of troops along the border. $^{293}$

From 5 February to 19 February 1987, India and Pakistan withdrew their forces from the border between Ravi and Chanab rivers. The withdrawal of troops took place in the northern half of Punjab province near the states of Jammu and Kashmir. The Brasstacks exercise, however, continued. ${ }^{294}$ On 2 March 1987 India and Pakistan signed an agreement to move nearly 70 percent of their troops away from the borders, but this time in the southern region of the Rajasthan sector. They were to begin on 6 March 1987, a day after the Brasstacks exercise concluded. ${ }^{295}$

These withdrawals of troops at the southern border officially ended the crisis. Western diplomats observed that the actual threat of the Indo-Pakistani conflict in Brasstacks laid in an accidental start of the hostilities. ${ }^{296}$ What, however, caused the peaceful settlement of the Brasstacks crisis? One may attribute it to the direct dialogue between India and Pakistan and to the Zia's visit to India in order to watch a cricket match which was later labelled as "cricket diplomacy." However, the direct dialogue between India and Pakistan at the beginning of the crisis was limited. The hotline was not used. The role of Zia's visit was also dubious. Although Zia declared the "cricket summit" as a success and announced that border tension between India and Pakistan was over $^{297}$, his cricket diplomacy was late and was the last step in the crisis.

If direct dialogue between India and Pakistan and Zia's cricket diplomacy had a limited role in settling the crisis, then the role of both US and Soviet mediation is worth mentioning. US engagement first manifested itself as a struggle to limit the nuclear dimension of the crisis. An overt

\footnotetext{
${ }^{292}$ The Times of India, February 2, 1987 in Bajpai K.P. et al. (1997). Brasstacks and Beyond, p. 172, and in Landay, J.S. (1987). India and Pakistan Continue Talks on Border Tensions. United Press International, 3 February 1987 [online] Available at:

http://www.upi.com/Archives/1987/02/03/India-and-Pakistan-continue-talks-on-border-tensions/1058539326800/

[Accessed 27.03.2017].

${ }^{293}$ IPS - Inter Press Service (1987). India: Pakistani and Indian Troops To Pull Back Immediately. 4 February 1987 NEXIS. and also in Lingam, T.S.K., India - Pakistan Sign Accord. United Press International, 4 February 1987 [online] Available at:

http://www.upi.com/Archives/1987/02/04/India-Pakistan-sign-accord/2504539413200/ [Accessed 27.03.2017].

${ }^{294}$ Labelle, G.G. (1987). India - Pakistan Tempestuous Teapot Slightly Less Steamy. The Associated Press, 6 February 1987 NEXIS. and also in United Press International (1987). India to Pull Troops from Pakistani Border. 5 February 1987 [online] Available at:

http://www.upi.com/Archives/1987/02/05/India-to-pull-troops-back-from-Pakistani-border/5091539499600/ [Accessed 27.03.2017].

${ }^{295}$ Ahmad, A. (1987). India and Pakistan Signed an Agreement Today to Remove. United Press International, 2 March 1987 [online] Available at: http://www.upi.com/Archives/1987/03/02/India-and-Pakistan-signed-an-agreement-today-toremove/6640541659600/ [Accessed 27.03.2017].

${ }^{296}$ Weisman, S.R. (1987). India - Pakistan Troop Tensions Ease. The New York Times, 5 February 1987 [online] Available at: http://www.nytimes.com/1987/02/05/world/india-pakistan-troop-tensions-ease.html [Accessed 27.03.2017].

${ }^{297}$ Tarnowski, A. (1987). Reuters Ltd. 22 February 1987 in Bajpai K.P. et al. (1997). Brasstacks and Beyond, p. 175.
} 
nuclear Pakistan was a fundamental problem for the US executive because the US government had to annually guarantee the US Congress that Pakistan did not have nuclear weapons. Only through these assurances, was the Congress permitted to provide military and financial aid to Pakistan. Reducing this aid would have had negative consequences for the US because Pakistan was playing a key role against the Soviet Union in the Afghan war. The most important development indicating the overt nuclearization of Pakistan was the statement of the father of Pakistan's nuclear program, A.Q. Khan. In his interview with an Indian journalist Kuldip Nayar, Khan admitted that Pakistan was enriching uranium at the Kahuta plant and already had developed a nuclear bomb. He added that Pakistan would use the bomb if its existence was threatened ${ }^{298}$ Reuters also reported that Khan told Nayar that ground tests were not necessary and a lab simulator would be enough for a test. ${ }^{299}$ Khan later denied this, and claimed that his sentences were taken out of context. ${ }^{300}$ One should mention here that although the interview was conducted on 28 January 1987, it was first published on 1 March 1987 after the crisis ceased. ${ }^{301}$ One can therefore argue that the interview did not have any role in ending the crisis. Considering the status of the interviewee, as the father of the Pakistani nuclear bomb, it is inconceivable to expect that the interview could have been conducted without informing both Pakistani and Indian officials. It is therefore plausible to claim that Khan's message was conveyed to India at the peak of the crisis. Nevertheless, it is not known how seriously India took the message. ${ }^{302}$

The US meddled with the Brasstacks crisis by directly communicating with both sides. US President Reagan telephoned both Rajiv Gandhi and General Zia-ul-Haq. He urged them to end the crisis. However, the exact day of his call is not clear and the role it played is disputable. ${ }^{303}$ What is important to note is that the direct communication between India and Pakistan failed. Therefore, one should still not underestimate the role of US mediation. ${ }^{304}$ On the one hand, the US threatened to cut off military and financial aid to Pakistan, if Pakistan did not give up its nuclear activities. For example, the US ambassador to Pakistan Deane R. Hinton gave a speech at the Pakistan Institute of

\footnotetext{
${ }^{298}$ The Observer (London), 1 March 1987 cited in Chari, P.R. (1995). Indo - Pak Nuclear Standoff: The Role of the United States. New Delhi: Ajay Kumar Jain Manohar Publishers \& Distributers, p. 130.

${ }^{299}$ Bajpai, R.(1987). Reuters Ltd. 2 March 1987 cited from Bajpai, K.P (1997). Brasstacks and Beyond, pp. 176 - 177.

${ }^{300}$ Dr. Qadeer denies interview The Nation (Lahore), 2 March 1987 cited in Chari, P.R. (1995). Indo-Pak Nuclear Standoff: The Role of the United States., p. 131.

301 The Observer [London] 1 March 1987 cited in Chari, P.R. (2003). Nuclear Crisis, Escalation Control, and Deterrence in South Asia. The Henry L. Stimson Center Working Paper Version 1.0, Washington DC. August 2003, p. 15. [online] Available at: https://www.stimson.org/sites/default/files/file-attachments/escalation_chari_1_1.pdf [Accessed 27.03.2017].

${ }^{302}$ Chari, P.R. (1995). Indo-Pak Nuclear Standoff: The Role of the United States, pp. 130 -131.

303 Bajpai K.P. et al. (1997). Brasstacks and Beyond, p. 42.

304 Chari, P.R. (2003). Nuclear Crisis, Escalation Control, and Deterrence in South Asia. The Henry L. Stimson Center, Working Paper, Version 1.0, p. 16. [online] Available at: https://www.stimson.org/sites/default/files/fileattachments/escalation_chari_1_1.pdf [Accessed 27.03.2017].
} 
Strategic Studies. He stated that if Pakistan acquired a nuclear capability, then Congress might have rejected financial and military assistance to Pakistan. ${ }^{305}$ On the other hand, the US advised India to immediately end the Brasstacks exercises because the scope of the Brasstacks was inciting fear in Pakistan and justifying Pakistani actions. For example, in January 1987 US officials told the visiting Indian Foreign Secretary A.P. Venkateswaran that

"The Brasstacks Exercise made it easier for Pakistan to obtain advanced weapons; while Brasstacks might improve the operational readiness of the Indian military, it had the ironic effect of strengthening Pakistan's case in Washington. ${ }^{\text {306 }}$

At the peak of the crisis on 23 January 1987, the Pakistani ambassador to India Humayun Khan was summoned to the Indian Ministry of External Affairs by the Minister of State for External Affairs Natwar Singh. Khan was asked to convey to his government a deadline for pulling back Pakistani troops deployed near the border. ${ }^{307}$ More importantly, the discussions between N.D. Tiwari (Indian Minister of External Affairs), Vasily Rykov (Russian Ambassador to India), Arun Singh (Indian Minister of State for Defense) and John Gunther Dean (US Ambassador to India) were also held on the same day in order to defuse the crisis. ${ }^{308}$ Arun Singh complained to US Ambassador Gunther Dean that the movement of Pakistan's Army Reserve South (ARS) from Bahwalpur to Sahiwal was threatening and required more information. In turn, American officials told the Pakistanis of this request. ${ }^{309}$ This was an important realization of US's intermediary role. Furthermore, the Indian Foreign Minister Narain Dutt Tiwari discussed the situation with Soviet Ambassador V. N. Rykov. ${ }^{310}$ On 23 January 1987, both Soviet and US diplomats became involved in a crisis prevention mechanism for the same country. This marks initial signs of collaboration, and illustrates how the US and the Soviet Union worked together in mediating a crisis with a nuclear dimension. It was an interesting point because although the Brasstacks crisis took place in the Cold War era, neither the US nor the Soviet Union pursued clientelistic policies. The US prioritized ending the crisis. Throughout the crisis, TASS and Izvestia, the Soviet Union's official barometers, maintained a neutral position. ${ }^{311}$ A military clash between Pakistan and India would have benefited

\footnotetext{
305 Weisman, S.R. (1987). Pakistan's Nuclear Aims Worrying U.S. The New York Times 20 February 1987 [online] Available at: http://www.nytimes.com/1987/02/20/world/pakistan-s-nuclear-aims-worrying-us.html [Accessed 27.03.2017].

${ }^{306}$ Bajpai K.P. et al. (1997). Brasstacks and Beyond, p. 91.

${ }^{307}$ Bobb, D. and Badhwar, I. (1987) Game of Brinkmanship. India Today, February 15, 1987 [online] Available at: https:/www.indiatoday.in/magazine/cover-story/story/19870215-game-of-brinkmanship-756869-1987-02-15 [Accessed 28.03.2017].

${ }^{308}$ Reuters North European Service. 23 January 1987, cited in Bajpai K.P. et al. (1997). Brasstacks and Beyond, p. 167.

${ }^{309}$ Bajpai K.P. et al. (1997). Brasstacks and Beyond, p. 82.

310 Barnetson, D. (1987). India forces on red alert at Pakistan border. United Press International, 23 January 1987 [online] Available at:

http://www.upi.com/Archives/1987/01/23/India-forces-on-red-alert-at-Pakistan-border/1986538376400/ [Accessed 28.03.2017].

${ }^{311}$ Bobb, D. and Badhwar, I. (1987). Back from the Edge. India, Pakistan hold marathon talks in New Delhi to defuse
} 
the Soviet Union since this would have weakened Pakistan's war efforts in Afghanistan against the Soviet Union ${ }^{312}$. However, the Soviet Union did not provoke the crisis to increase its own gain. This shows that although there was harsh competition between the US and the Soviet Union in Afghanistan, they displayed collaborative behavior in a crisis which had a nuclear dimension.

Although the Brasstacks crisis ended, the political turmoil in the State of Jammu and Kashmir led another crisis to occur in South Asia, where the nuclear dimension of the conflict became more evident by the day. Below is the next crisis between India and Pakistan.

\subsubsection{The 1990 Kashmir Crisis}

\subsubsection{Overview}

Kashmir had again become the focal point of political struggles between India and Pakistan at the end of eighties. Widespread protests took place in the State of Jammu and Kashmir against Indian rule in 1989. The combination of diverse factors played a role in leading to these uprisings. An important factor was the elections in 1987 in Kashmir, which was widely believed as rigged by the Indian government. ${ }^{313}$ Another vital development was the withdrawal of the Soviet Union from Afghanistan. Some Islamist groups fighting against the Soviet Union became independent and infiltrated South Asia to fight against Indian rule, inflaming the already tense situation in Kashmir. ${ }^{314}$ Another important factor was the harsh Indian rule in Kashmir. This caused resentment among the young Kashmiri population and culminated into uprisings. ${ }^{315}$ In January 1990, the situation became critical when police forces fired on demonstrators. ${ }^{316}$ The uprisings increased the tension in India- Pakistan relations. India accused Pakistan of destabilizing the Kashmiri region by supporting Kashmiri "terrorists". Pakistan claimed that it gave only moral support to "freedom fighters". 317

Military exercises also increased the tension between India and Pakistan. Pakistan started a massive military exercise, Zarb-i-Momin, on 9 December 1989. The exercise was built on a

border crisis. India Today, 28 February 1987 [online] Available at:

http://indiatoday.intoday.in/story/india-pakistan-hold-marathon-talks-in-new-delhi-to-defuse-bordercrisis/1/336739.html [Accessed 28.03.2017].

${ }^{312}$ Cohen, S. P. (1991). Superpower Cooperation in South Asia edited by Roger E. Kanet and Edward A. Kolodziej (eds.) (1991). The Cold War As Cooperation: Superpower Cooperation in Regional Conflict Management. London: Macmillian Academic and Professional Ltd., p. 287.

313 India Today (1990). The Enemy Within. 'It is perhaps a singular Indian trait to look for scapegoats.' 31 March 1990 [online] Available at: http://indiatoday.intoday.in/story/it-is-perhaps-a-singular-indian-trait-to-look-for-scapegoats/1/316403.html [Accessed 28.03.2017].

${ }^{314}$ BBC News: India - Pakistan Troubled Relations: Kashmir Insurgency [online] Available at: http://news.bbc.co.uk/hi/english/static/in_depth/south_asia/2002/india_pakistan/timeline/1989.stm [Accessed 28.03.2017].

${ }^{315}$ Hagerty, D.T. (1995-1996). Nuclear Deterrence in South Asia: The 1990 Indo - Pakistani Crisis. International Security, Vol. 20, No.3, Winter 1995 - 1996, The MIT Press, pp. 93- 94.

316 Ibid. p. 96.

${ }^{317}$ Hagerty, D.T. (1995-1996). Nuclear Deterrence in South Asia. International Security, p. 94. 
scenario aiming at a preemptive attack in north Punjab. This caused significant concern in the decision-making circles of India. B.G. Deshmukh, the principal secretary to the then Indian Prime Minister V.P. Singh, pointed out that a possible Pakistani attack on north Punjab would impede India to supply additional troops to the region in a real war situation. Deshmukh also promoted the Indian position that Pakistan would attack after monsoon broke and in the meantime, terrorists supported by Pakistan would declare their independence in Srinagar and invite Pakistan to protect them, causing a fait accompli in the State of Jammu \& Kashmir. ${ }^{318}$

India responded to these exercises by sending troops to the States of Jammu and Kashmir and Punjab. In February 1990, India sent two new tank units to Mahajan in Rajasthan, which was disconcerting for Pakistan. The US ambassador to India William Clark argued that this action was unsettling because Pakistan was not sure whether these movements were only an exercise or were actually designed to launch a big offensive. ${ }^{319}$ As a result of these worrisome developments, US military attaches in New Delhi and Islamabad took reconnaissance trips in February to check the situation and determine whether Indian and Pakistani forces were preparing for offensive. ${ }^{320}$

The nuclear dimension of the conflict was also becoming visible. For example, Indian Prime Minister V.P. Singh met with Air Chief Marshal Mehra to determine whether India had the capability to respond to a Pakistani first strike. The Air Force said there was no such a guarantee and that India should develop nuclear deterrence. ${ }^{321}$ V.P. Singh later stated that "India would have to review its peaceful nuclear policy, if Pakistan would employ its nuclear power for military purposes." ${ }^{322}$ V.P. Singh was also asked in an interview whether India deploy nuclear weapons during the conflict. He replied that:

"We want to avoid conflict, but if it comes we have nothing to fear. If Pakistan were to go nuclear, we will have to take stock of the situation and act accordingly. ",323

Benazir Bhutto also increased the tension by stating that Kashmiri militancy was indigenous and intrinsic. She even openly proclaimed the Kashmiri's right to self-determination. ${ }^{324}$ In

\footnotetext{
${ }^{318}$ Deshmukh, B.G. (1994). The Inside Story. 'The 1965 and 1971 wars were solely due to Pakistan's provocative action. 'India Today, 28 February 1994 [online] Available at:

http://indiatoday.intoday.in/story/the-1965-and-1971-wars-were-solely-due-to-pakistans-provocativeaction/1/294879.html [Accessed 28.03.2017].

${ }^{319}$ Krepon, M and Faruqee, M. (eds.) (1994). Conflict Prevention and Confidence-Building Measures in South Asia: The 1990 Crisis. The Henry L. Stimson Center, Occasional Paper, No. 17, April 1994, p. 3 [online] Available at: https://www.stimson.org/sites/default/files/file-attachments/occasionalpaper17-web_1.pdf [Accessed 23.03.2017].

${ }^{320}$ Ibid. pp. 13- 19.

${ }^{321}$ Perkovich, G. (1999). India's Nuclear Bomb, p. 305.

${ }^{322}$ Xinhua General News Service Indian Prime Minister on His Country's Nuclear Policy. 21 February 1990, Wednesday NEXIS.

${ }^{323}$ Far Eastern Economic Review, 17 May 1990, p. 11, cited in Chari, P.R., Cheema, P. I., and Cohen, S. P. (2003). Perception, Politics and Security in South Asia: The Compound Crisis of 1990, London and New York: Routledge Curzon, Taylor \& Francis Group, p. 73.
} 
Muzaffarabad, she promised a thousand years of war if necessary to support Kashmir. ${ }^{325}$ Through these statements, Bhutto declared Pakistan's open support of Kashmiri uprisings and of the fighting groups in Kashmir. These hawkish statements of Bhutto led V.P. Singh to respond with identical statements. V.P. Singh quickly stated India would react decisively against a Pakistani intervention in Kashmir. He stated in the Lok Sabha ${ }^{326}$ that a misstep from the Pakistani side would not be without costs. ${ }^{327}$ V.P. Singh also responded to Bhutto's thousand-years war threat with these words:

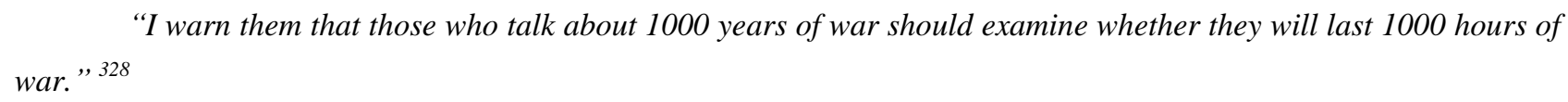

Another pugnacious statement came from Baharatiya Janata Party (BJP) ${ }^{329}$ in India. The BJP party announced that training camps and transit routes for terrorists should be destroyed. BJP further argued that the doctrine of hot pursuit is a recognized defensive measure. ${ }^{330}$ Rajiv Gandhi, the former Prime Minister of India, also made a hawkish statement and covertly indicated the nuclear capability of India. He stated that:

"I know what steps are possible. I also know what is in the pipeline and what the capabilities are. The question is: does the government have the guts to take strong steps?",331

One could also observe how the situation was deteriorating in the parliamentary speeches. On 10 April 1990, V.P. Singh made a series of speeches in Lok Sabha. He warned that "Indians should be psychologically prepared for war". He also added that "Pakistan could not get away with taking Kashmir without a war." ${ }^{332}$ Sayeed, the Home Minister of India, also warned that:

"War with Pakistan would be fully justified if the objective of freeing Kashmir from the stranglehold of the secessionists was achieved. ",333

\footnotetext{
${ }^{324}$ Viswam, S. and Salamat A. (1990). Vale of Tears. Far Eastern Economic Review, 8 February 8 1990, p. 20.

325 Asghar, R. (1990). Bhutto Predicts Victory for Kashmir Independence Campaign. Reuters Library Report, 13 March 1990, cited in P.R. Chari et al. (2003). Perception, Politics and Security in South Asia: The compound crisis of 1990, p. 74.

${ }^{326}$ Lok Sabha is the lower house of Indian Parliament. The higher house is the Rajya Sabha.

${ }^{327}$ Manoharan, M. (1990). Indian Leader Tells Pakistan to Stay Out of Kashmir Uprising. Reuters Library Report, 13 March 1990 cited in Chari, P. R. et al. (2003). Perception, Politics, and Security in South Asia, p. 74.

${ }^{328}$ Fineman, M. (1990). India's Leader Warns of an Attack by Pakistan: War fears: Trouble in Kashmir and terrorism have raised tensions. Internal political unrest in both nations could push them toward conflict. Los Angeles Times, 15 April 1990. [online] Available at: http://articles.latimes.com/1990-04-15/news/mn-1984_1_political-unrest [Accessed 28.03.2017].

${ }^{329} \mathrm{BJP}$ is a right wing political party with links to Hindu nationalism. It is the governing party in India since 2014 elections.

330 Times of India, Crush Pak Camps: BJP, 8 April 1990 cited in Chari, P. R. et al. (2003). Perception, Politics, and Security in South Asia, p. 75.

${ }^{331}$ Housego, D. (1990). India Urged to Attack Camps in Pakistan Over Strife in Kashmir. Financial Times, 9 April 1990 , cited in Chari, P. R. Chari et al. (2003). Perception, Politics, and Security in South Asia, p. 75.

332 Chari, P. R. et al. (2003). Perception, Politics, and Security in South Asia, p. 75.

333 Coll, S. (1990). Assault on Pakistan Gains Favor in India. Washington Post, 15 April 1990 [online] Available at: https:/www.washingtonpost.com/archive/politics/1990/04/15/assault-on-pakistan-gains-favor-in-india/0a3abaed-4dac4bf2-9ade-e92ca2d62a26/ [Accessed 28.03.2017].
} 
The BJP leader, L.K. Advani threatened that "Pakistan would cease to exist if it attacked India" 334

The exchange of statements above indicate that despite nuclear capability, both countries did not necessarily engage in peaceful discourse. Instead, they continued with threatening statements as in the conventional period. This gives some insights into the role of international mediation in easing crises. Below I began with the US mediation.

\subsubsection{US Mediation of the 1990 Kashmir Crisis:}

Because of increasing threats posed by Indian and Pakistani politicians, the US was deeply concerned with the situation. However, during this time, South Asia was not considered a strategic region for the US. The Soviet Union had retreated from Afghanistan and thus, Pakistan was no longer a valuable ally. Furthermore, the US was busy with estimating the new emerging international structure and global issues in case of a possible dissolution of the Soviet Union. ${ }^{335}$ Nonetheless, the US viewed the crisis between India and Pakistan as a serious issue due to the nuclear dimension of the conflict. The US believed that Pakistan possessed not only nuclear capabilities, but also built a nuclear weapon. For example, the US Under Secretary of Defense, Paul Wolfowitz, reported that the US knew that Pakistan had a nuclear weapon. ${ }^{336}$

On 16 February 1994, four years after the 1990 crisis, an on-the-record discussion meeting was held by the Henry L. Stimson Center. ${ }^{337}$ In this meeting, the US Ambassador to India William Clark stressed that the US was highly concerned about the Kashmir crisis. He said that US officials were taking the crisis so seriously that they were in a more panicked state than the Indian and Pakistani officials. US Ambassador Clark said that:

“... The concern in Washington went up quicker than concern in Delhi did., 338

The US ambassador's statement demonstrates the interest of the US in the crisis. Clark also added that:

"We felt that there was a need, at least in Delhi, for some overtures on the part of the US. Exactly, what that overture would be, perhaps a visit by someone of significant stature to come out and see if there wasn't something that the US could do was one option. "339

\footnotetext{
${ }^{334}$ Chicago Tribune (1990). Indian Forces Battle Moslems in Kashmir. Chicago, 16 April 1990 cited in Chari, P. R. et al. (2003). Perception, Politics, and Security in South Asia, p. 86.

${ }^{335}$ Khan, S. (2009). Nuclear Weapons and Conflict Transformation: The case of India-Pakistan. The USA and Canada: Routledge, p. 106.

${ }^{336}$ Reiss, M. (1995). Bridled Ambition. Baltimore: The John Hopkins University Press, p. 188.

337 The Stimson Center is a nonprofit and nonpartisan think tank that finds solutions to global security challenges. Definition is cited from its website [online] Available at: http://www.stimson.org/about/ [Accessed 28.03.2017].

${ }^{338}$ Krepon, M. and Faruqee M. (1994). Conflict Prevention and Confidence Building Measures in South Asia: The 1990 Crisis, p.4
} 
The intelligence community of the US was more alarmed than the embassies in the region. Intelligence agencies reported that Pakistan was preparing for the delivery of nuclear weapons. ${ }^{340}$

These concerns led to the organization of the Gates Mission. The Bush administration sent a diplomatic mission led by Deputy National Security Adviser Robert Gates to Islamabad and New Delhi to defuse the situation. The other members of the mission were John Kelly and Richard Haas. Gates visited both Pakistan and India. In Pakistan, he talked with the President of Pakistan Ghulam Ishaq Khan and the chief of the army staff Mirza Aslam Beg. He told them that "Washington had war-gamed the Indo-Pakistani confrontation, and there is no a single way Pakistan can win." Gates also urged Pakistani leaders to tone down their public statements, in order to avoid new military deployments. Additionally, he pointed out that some political parties in the Pakistani held Kashmir region provide arms to secessionist groups in the Indian held Kashmir and warned Pakistani leaders to stop these activities. Gates also added that if war breaks out the US would not help. ${ }^{341}$

Afterwards Gates visited India. He held talks with Prime Minister V.P. Singh and Chief of Army Staff General Sharma. He warned that India should avoid provocation that could spiral out of control. Gates mainly communicated the message that winning the war would be so costly that in practice there would be no winner at all. ${ }^{342}$

Within two weeks of Gates' mission, India and Pakistan withdrew their military forces and the crisis subsided.

The Gates mission was generally considered a successful mediation attempt. The US Ambassador to India William Clark reported:

"At the end of the day, I think you could say that both Delhi and Islamabad used Gates and his mission as an excuse, if you will, to back off of positions they had been taking. We were rather pleased to have been the excuse, and for the first time in a long time, the United States was seen as not favoring one or the other. "343

This statement from Ambassador Clark demonstrated that the US considered the crisis as serious, and did not pursue clientelistic policies. Its main objective was to ease the crisis, not to support one party. Both actors also recognized this. It prevented one party of the conflict from

\footnotetext{
${ }^{339}$ Ibid.

${ }^{340}$ Hagerty, D.T. (1995-1996). Nuclear Deterrence in South Asia. International Security, p. 105.

${ }^{341}$ Hersh, S. (1993). On the Nuclear Edge. The New Yorker, 29 March 1993 [online] Available at: http://www.newyorker.com/magazine/1993/03/29/on-the-nuclear-edge [Accessed 29.03.2017] and Burns, J.F. (1990). US Urges Pakistan to Settle Feud With India Over Kashmir. The New York Times, 21 May 1990 [online] Available at: http://www.nytimes.com/1990/05/21/world/us-urges-pakistan-to-settle-feud-with-india-over-kashmir.html [Accessed 28.03.2017].

${ }^{342}$ Hagerty, D.T. (1995). Nuclear Deterrence in South Asia: the 1990 Indo-Pakistani Crisis International Security, p. 101.

${ }^{343}$ Krepon, M. and Faruqee M. (1994). Conflict Prevention and Confidence Building Measures in South Asia: The 1990 Crisis, p. 4.
} 
siding with the US to place pressure on the other side. It meets the conditions of into the Expectation 5.

The statements coming from India and Pakistan also supported this assumption. For example, Pakistani Ambassador Abdul Sattar stated that he viewed the mission positively. He stated that:

"I think that what is important is not what was happening in the months of January and February, but the projection of what might happen if the trends in motion were not arrested. And I think it is here that the American diplomacy deserves credit. ... What happened in the spring of 1990 is an illustration of good, useful preventive diplomacy. "344

Ambassador Clark reported that Indian officials also appreciated the chance to ease the tension:

"I did have several senior people, including the prime minister, tell me afterwards that it had been a useful visit, it had allowed a way to back off for both sides, without one having back down to the other. "\$45

Here, it can be noted that there was praise from both parties of the conflict about the mediation effort. It meets the criteria of the Expectation 6.

On the other hand, there are also some officials attributing the easing of the crisis not to US mediation and the Gates mission, but mainly to deterrence between India and Pakistan. For example, a renowned Indian expert in the field of international security, Krishnaswamy Subrahmanyam, stated in an interview made by Saira Khan that:

"The chances of war occurring between India and Pakistan are low...compared to what happened in 1965 and 1971. This is because of Pakistan's nuclear weapons capability. It is quite obvious that there is not likely to be any war between Indi and Pakistan now, unless one or the other is going to cross the line of control at the frontier. "346

General Sundarji also added that it was not conceivable that in 1990 there would have been a total war between India and Pakistan. He believes that the Brasstacks crisis was the last allconventional crisis in which India could have used its conventional superiority to destroy Pakistan's conventional and nuclear weapons capability. ${ }^{347}$ General Sundarji even added that:

"If you could go back to 1947 as a method of replaying events once again, but with the added change of a nuclear capability of this nature as a backdrop, I rather suspect that many of those three wars would not have

\footnotetext{
${ }^{344}$ Ibid. pp. 30-31.

345 Ibid. pp. 32-33.

${ }^{346}$ Khan, S. (2009). Nuclear Weapons and Conflict Transformation: The Case of India - Pakistan, pp. 105 - 106.

${ }^{347}$ Perkovich, G. (1999). India's Nuclear Bomb, p. 295.
} 
happened...Because of nuclear deterrence, the menu of Indian responses to Pakistani provocation in Indian held Kashmir no longer includes launching a bold offensive thrust across the Punjab border. "348

These statements, however, focus only on the possibility of breaking out of a sudden major war. Experts emphasizing only direct deterrence do not consider the low threshold that could be exceeded in the threats of preemptive or limited attacks. It is important especially in the IndoPakistani context in which the nuclear capabilities were still nascent. In these phases, international mediation deserve credit as a having served as a complementary force to direct deterrence.

The US mediation of the 1990 war meets the criteria of Expectation 4: collaboration. One likely action of Expectation 4 holds that mediator states do not blame each other. The US blamed neither Russia nor China for the conflict. Another likely action of Expectation 4 is that mediator states would consider offering their services or emissaries to enable a dialogue between the sides of the conflict. The Gates mission, for example, fulfills this assumption. The Gates mission was not a joint diplomatic effort; nevertheless, China and Russia did not object or prevent the Gates mission and its activities. ${ }^{349}$ It is also important to note here that Gates went to South Asia right after his visit to Moscow, bringing the same message from Moscow to both India and Pakistan. It demonstrates an expectation of collaboration. ${ }^{350}$

The US was not pro-Pakistani or pro-Indian. This fits to the likely actions of Expectation 5. Expectation 5 requires that mediator states do not align with one party of the conflict, helping international mediation being more effective.

\subsubsection{The Soviet Mediation of 1990 Kashmir Crisis}

During the 1990 Kashmir Crisis, the Soviet Union's mediation behavior was not consistent with its mediation pattern concerning the crises before 1980s. The Soviet Union had been blatantly pursuing a pro-Indian policy before the 1980s. However, during the 1990 crisis, the Soviet Union took a neutral role. Both the US and the Soviet Union were against the war and discouraged India and Pakistan from fighting in the 1990 Kashmir Crisis. ${ }^{351}$ Ambassador Robert Oakley, for example, indicated in the Stimson Center Meeting that both Moscow and Beijing also sent identical messages to India and Pakistan asking them to back off. ${ }^{352}$

\footnotetext{
${ }^{348}$ Hagerty, D.T. (1998). The Consequences of Nuclear Proliferation: Lessons from South Asia. MA: MIT Press, pp. 167-168.

349 Thornton, T. and Bratersky, M. (1995). India and Pakistan: The Roots of the Conflict in I. William Zartman and Victor A. Kremenyuk (eds.) Cooperative Security: Reducing Third World Wars. Syracuse: Syracuse University Press, p. 194.

${ }^{350}$ Krepon, M., Faruqee, M. (1994). Conflict Prevention and Confidence-Building Measures in South Asia: The 1990 Crisis, p. 9.

${ }^{351}$ Thornton, T. and Bratersky, M. (1995). India and Pakistan: The Roots of the Conflict in I. William Zartman and Victor A. Kremenyuk (eds.) Cooperative Security, p. 193.

${ }^{352}$ Krepon, M. and Faruqee M. (1994). Conflict Prevention and Confidence Building Measures in South Asia: The 1990
} 
One can also attribute this neutrality to changing geopolitical conditions. The Soviet Union had withdrawn from Afghanistan and the Cold War was approaching its end. Therefore, rather than a nuclear dimension, shrinking Soviet power was what compelled the Soviet Union to stay neutral. However, Soviet behavior also demonstrates similarities with the Soviet behavior in the 1987 Brasstacks Crisis and with other small crises at the beginning of the 1980s. One can potentially argue that by 1990, the Soviet Union had very limited power and did not show any interest in the conflict. However, the Soviet Union demonstrated the same behavioral pattern in the 1980s, and did not provoke the conflict between India and Pakistan in the 1980s. However, one may argue that the Soviet Union did not spark a conflict in South Asia even in the 1980s because the collapse of the Soviet Union was a process that had already begun in the early 1980s. Even if it were true, however, overtly supporting India and provoking the India-Pakistan conflict could have provided certain advantages to the Soviet Union in the 1980s. A war between India and Pakistan could have enforced Pakistan to invest extensively in the war with India. Pakistan would have focused more on the Indian dispute, thus allocating relatively less resources against the Soviet Union in Afghanistan. This would have partly relieved the Soviet Union in Afghanistan. In other words, while it is reasonable to argue that the Soviet Union was not actively involved in the crises of the 1980s due to lack of resources, it would have been in the Soviet interest to pursue any policy which contributed to a war between India and Pakistan in order to provide a certain amount of relief for the Soviet Union in its difficult and costly war in Afghanistan. One should further consider that India also did not entirely support Soviet actions in Afghanistan. ${ }^{353}$ A more pro-Indian stance in the conflicts of the 1980s, at least rhetorically, would have helped the Soviet Union receive more support from India in the international arena. However, the Soviet Union did not pursue such a policy.

The evaluation of the Soviet Union's mediation efforts in the 1980s and the early 1990s, however, requires that one should still consider the severe economic problems faced by the Soviet Union. Before analyzing the Chinese mediation of the 1990 Kashmir crisis, therefore, it is necessary here to elaborate on the impact of the shrinking Soviet power and the approaching end of the Cold War on Soviet behavior towards the crises in South Asia. Below, I shortly discussed the particularities of the Soviet domestic situation in the 1980s and the early 1990s.

The poor economic conditions of the Soviet Union in the 1980s were already perceivable in the era of Leonid Brezhnev. ${ }^{354}$ Moreover, the end of the détente between the US and the Soviet

\footnotetext{
Crisis, p. 9.

${ }^{353}$ For a detailed analysis of discrepancy between the Soviet Union - India over Afghanistan war see: Horn, R.C. (1983). Afghanistan and the Soviet - Indian Influence Relationship, Asian Survey, Vol. 23, No. 3 (March, 1983), University of California Press, pp. $244-260$.

${ }^{354}$ Leonid Brezhnev was the General Secretary of the Central Committee of the Communist Party of the Soviet Union from 1964 to 1982 .
} 
Union due to the war in Afghanistan rendered unmaintainable the already stagnated Soviet economy. Brezhnev, an ardent supporter of détente, died in 1982. After Brezhnev, the Soviet Union experienced two short-term leaderships. Yuri Andropov was elected as the successor of Brezhnev in 1982 and died in 1984. Later, Konstantin Chernenko became the General Secretary of the Communist Party of the Soviet Union in 1984 and died in 1985. During these two terms, called as the interregnum, there were no notable reforms in Soviet domestic politics, apart from the anticorruption campaign initiated by Andropov. After these two-short terms, Michael Gorbachev took power on 10 March 1985. Gorbachev was very young and reform-oriented. He later called the Brezhnev era as an era of stagnation. ${ }^{355}$ In the Gorbachev era, however, economic problems intensified. The deteriorating economic situation compelled reforms and this was more obvious by the mid 1980s. The Soviet Union was spending more hard currency than it earned at the beginning of $1985 .^{356}$ Gorbachev thus initiated his ambitious reforms: perestroika and glasnost, which means restructuring and openness, respectively. These reforms aimed at reforming Soviet political and economic life. Nevertheless, economic problems worsened. On 30 October 1986, Gorbachev complained in a Politburo session that the Soviet state "started to borrow from the population and rely on emissions of paper money. Salaries became unlinked from the productivity of labor." 357 Gorbachev summarized the economic crisis in the Soviet Union as "the situation holds us by our throat." ${ }^{, 358}$ Gorbachev also objected to the rise in prices in the same meeting. He believed that the rise in prices would carry unforeseeable political consequences and would endanger the perestroika. ${ }^{359}$ Despite the ambitious character of the reforms, the economic situation in the Soviet Union deteriorated. In the end, the political structure of the Soviet Union was impaired and ended with the dissolution of the Soviet Union in December 1999.

The significant domestic problems experienced by the Soviet Union in the 1980s demonstrated that the Soviet Union did not have enough resources to invoke another conflict in South Asia. The same reason also compelled the Soviet Union to remain neutral during the 1990 Kashmir conflict. This line of approach does not explain, however, the Soviet incentive to actively

\footnotetext{
${ }^{355}$ Gorbachev, M. (1995). Zhizn i reformy Vol. 1, Moscow: Novosti. p. 218, cited in Bacon, E. (2002). Reconsidering Brezhnev in Edwin Bacon and Mark Sandle (eds.) Brezhnev Reconsidered, New York: Palgrave Macmillan, p. 1.

${ }^{356}$ Pikhoia, Rudolf G. (2004). "Pochemu raspalsia SSR?" in Konets kholodnoi voini: noviie fakti i aspekti, edited by V.M. Zubok, S.Y. Shenin, and A.A. Shubin. Saratov: Nauchnaia Kniga, 2004 cited in Zubok, V. M. (2009). A Failed Empire: The Soviet Union in the Cold War from Stalin to Gorbachev. The US: The University of North Carolina Press, pp. 298-299.

35 NSARCHIVE, Notes from the Politburo Session, 30 October 1986, by Anatoly Chernyaev, The Gorbachev Foundation Archive, Translated by Svetlana Savranskaya for the National Security Archive pp. 1-2 in NSARCHIVE The Reykjavik File, Document 23, USSR CC CPSU Politburo Session. [online] Available at: https://nsarchive2.gwu.edu/NSAEBB/NSAEBB203/index.htm or directly Available at:

https://nsarchive2.gwu.edu/NSAEBB/NSAEBB203/Document23.pdf [Accessed 03.01.2018].

358 Ibid.

${ }^{359}$ Ibid.
} 
support the US initiative of the Gates Mission. Taking a neutral and passive position did not necessarily require the active support to the US endeavors.

Soviet lack of activity during the crises of the 1980s in particular was less understandable, considering Pakistan's role in the war in Afghanistan as immediately above explained. These Soviet behaviors during the crises of the 1980s and in the case of the 1990 Kashmir Crisis are critical and deserve particular consideration even if one accepted that the declining economic state of the Soviets was a vital factor that affected Soviet behavior during these decades. One should also compare Soviet behavior at the start of the 1990s with the end of 1990s before determining the extent to which diminished Soviet power affected its behaviors towards the crises in South Asia. It should be noted that Russian foreign policy started to change in 1993, which continued to evolve throughout the decade. The situation becomes clear when one further analyzes the domestic situation in Russia in the 1990s, which I will do in the section of addressing Russian mediation of the 2001-02 military standoff between India and Pakistan.

\subsubsection{Chinese Mediation of the 1990 Kashmir Crisis}

Before the crises in 1980s, China had resolutely taken a pro-Pakistani stance on the crisis between India and Pakistan. In a previous part of this study, I demonstrated that highly ranked Chinese officials and politicians had not refrained from publicly disclosing their pro-Pakistani policies. However, China's response to the 1990 crisis departed dramatically from its previous stance in the crises early on. In the 1990 crisis, China was more passive than it had been in the crisis before. Without supporting any part of the crisis, it encouraged both UN and US initiatives. For example, on 16 February 1990 the Chinese Foreign Minister Qian Qichen said to Iqbal Akhund, Pakistan's Prime Minister's foreign advisor that:

"China hopes that they will solve their dispute peacefully through friendly negotiations and in accordance with the relevant decisions of the United Nations and the Simla Agreement reached by the two countries. Only through the maintenance of stability in South Asia can the countries in the area develop their economies and improve the lives of their peoples. "360

By stressing the Simla Agreement, China clearly indicated that it is not pro-Pakistan. Pakistan lost East Pakistan after the Simla Agreement and this agreement continues to invoke bad memories to present day. This was a serious blow for Pakistani officials hoping to gain China's support.

On February 20, only four days after the meeting between Qian Qichen and Igbal Akhund, a military mission led by the Chinese Defense Minister General Qin Jiwei visited Pakistan. They met

\footnotetext{
${ }^{360}$ Xinhua General News Service (1990). Chinese Foreign Minister meets Pakistan's Special Envoy. 16 February 1990, Friday from NEXIS.
} 
with Prime Minister Benazir Bhutto. Although Bhutto marked the importance of a Pakistani Chinese friendship during the visit, it was not enough to impress the Chinese delegation. Quin Jiwei emphasized that:

"China hopes that India and Pakistan will solve the Kashmir issue in accordance with the relevant United Nations resolutions and agreements between the two countries, and through friendly consultations on the basis of five principles of peaceful coexistence. ${ }^{, 361}$

This tone set above, was very different from China's position during the 1965 and 1971 crisis. Supporting the UN Resolutions demonstrates that China did not want to play an active role in the conflict. Instead, China encouraged Pakistan to search for international solutions.

To summarize, the behaviors of Russia and China mainly supported the assumptions of Expectation 4: collaboration. Russia and China did not support their traditional allies, India and Pakistan respectively. They did not try to sabotage the mediation efforts of the US, rendering mediation more effective and making India and Pakistan more amenable to mediation. It was also notable in the case of China that Bhutto tried to garner Chinese support, which China rejected multiple times. It fits Expectation 5 that mediators rejected the alignment demands of the parties of the conflict, rendering the mediation of the Gates mission more effective. The statements of both Indian and Pakistani politicians praising the Gates mission fits Expectation 6 that leaders of the conflicting parties could use mediation as a tool to withdraw, and thereby overwhelm domestic pressures.

\subsubsection{Kargil War}

\subsubsection{Overview}

Kargil is a highly mountainous area located in the Ladakh region in the State of Jammu \& Kashmir. The geographical conditions are stiff in the region, making it difficult for the military to maneuver. There was an informal understanding between India and Pakistan to refrain from having a military presence in the region from 15 September to 15 April each year. ${ }^{362}$ However, Pakistani troops together with Kashmiri militants crossed the Line of Control (LOC) and violated this informal agreement in the spring of 1999. Pakistan assumed that the Indian response would not be immense and Pakistani troops and Kashmiri militants could have taken the upper hand in the Kargil sector before Indian troops realized the intrusions. However, the Indian reaction was massive as the

\footnotetext{
${ }^{361}$ Xinhua General News Service (1990). Pakistan Prime Minister meets Chinese Defense Minister. 20 February 1990, Tuesday from NEXIS.

362 Global Security.org (1999). 1999 Kargil Conflict [online] Available at:

http://www.globalsecurity.org/military/world/war/kargil-99.htm [Accessed 28.03.2017].
} 
infiltrations came as a complete surprise. ${ }^{363}$ Pakistan's military strategy posed a great danger to India because the intrusions also targeted National Highway 1A, the road connecting Srinagar and Leh and the only major supply route to Indian forces in the area. ${ }^{364}$ As a reaction to the intrusions, India launched a counter operation to ward off infiltrators from Kargil. ${ }^{365}$

Indian operations had three components. The land component was named Operation Vijay. It was fought in a mountainous area. Indian troops managed to capture the Tololing complex in Drass, Tiger Hill, and the Mashkoh Valley. There were also air operations, named Operation Safed Sagar. The fighter jets have low maneuver capability at high attitudes. The air operations were therefore difficult due to the high attitude in the region. The Indian Navy also sent warships to the Arabian Sea to block the Pakistani Navy in Karachi. ${ }^{366}$ This was a significant act, because Karachi was a vital port and most of the oil imported by Pakistan came through this port. The situation was exceedingly tense. The then Foreign Secretary of Pakistan Shamshad Ahmed even stated that

"Pakistan is willing to use any weapon in our arsenal to defend our territorial integrity. "367

Ahmed was referring to the Pakistani nuclear capability and to the determination to deploy nuclear weapons in a serious situation.

In the end, Pakistani forces withdrew from the Kargil sector, and the crisis ended. The extent of Indian operations and the blocking of Karachi, one of the important ports of Pakistan, shows that even in the nuclear dyads the intensity of the crisis can be very high. This demonstrated the need for international mediation, even in the context where direct communication channels between India and Pakistan were open. During the Kargil conflict, Indian and Pakistani prime ministers spoke with each other on the phone. On 24 May 1999, for instance, Indian Prime Minister Vajpayee called Shariff, and warned him that all possible steps would be taken to clear the territory from intruders. As a response, on 28 May 1999 Shariff called Vajpayee, and offered to send Pakistani Foreign Minister Sartaj Ali for talks. ${ }^{368}$ There were also a backchannel of communication between India and Pakistan. Pakistan nominated former Pakistan Foreign Secretary, Niaz A. Naik, and India nominated an Indian journalist R.K. Mishra for the meetings. ${ }^{369}$ There were therefore no lack of

\footnotetext{
${ }^{363}$ Kargil Review Committee (2000). From Surprise to Reckoning. New Delhi: Thousand Oaks SAGE Publications, p. 223.

${ }^{364}$ Wirsing, R.G. (2003). Kashmir in the Shadow of War: Regional Rivalries in a Nuclear Age. New York: M.E. Sharpe Inc., p. 36.

${ }^{365}$ Chen, L.C. (2015). What Should be Knowing about the Kargil War. India Today, 26 July 2015 [online] Available at: http://indiatoday.intoday.in/story/kargil-war-vijay-diwas-facts/1/454125.html [Accessed 28.03.2017].

366 Dixit, J.N. (2002). India - Pakistan in War \& Peace. London and New York: Routledge Taylor \& Francis Group, p. 34.

${ }^{367}$ CNN World (1999). India Agrees to Kashmir Talks. 31 May 1999 [online] Available at: http://edition.cnn.com/WORLD/asiapcf/9905/31/india.pakistan.01/ [Accessed 28.03.2017].

368 Chengappa, R. (1999). Dial-A-PM. India Today, 22 June 1999 from NEXIS.

${ }^{369}$ Noorani, A.G. (1999). ‘An Aborted Deal? '. India \& Pakistan. Frontline, Volume 16, Issue 18, 28 August - 10
} 
communication between the parties of the conflict during the crisis. One of the duties of mediation, facilitating the communication between parties of the conflict, more or less occurred during the Kargil conflict even before international mediation. Therefore, mediation here played the role of not only facilitating communication but also deterring the crisis. Next, I will explain the role of mediation in detail.

\subsubsection{US Mediation of the 1999 Kargil War}

In analyzing US mediation of the Kargil conflict, I started with congressional hearings. From these hearings, I detected that the nuclear component of the crisis put the Clinton administration at unease. Immediately following the nuclear tests, serious debates were held in the US Congress concerning a possible crisis in South Asia with a nuclear dimension. Even a year before the Kargil crisis, US attention to the region had begun to increase. In the US House of Representatives, they had even discussed an article written by the RAND Cooperation ${ }^{370}$ on the crisis. It was about the possibility of war in South Asia involving a nuclear dimension. Under the guidance of this article, Dan Burton, a representative of Indiana in the US House of Representatives, warned on 23 April 1998 that:

"The prospect of a nuclear war in South Asia must be distressing to anyone. This event could pose a major threat to the entire world. We should all commit ourselves to making pressure that even if war does break out, it is fought without the use of nuclear weapons. "371

In his statement, Burton stressed that the crisis between India and Pakistan was not only a matter between two actors, but had wider implications on the entire world. Another hearing held in the Congress also notes the danger posed on the world from a nuclear South Asia. Robert Underwood, representative from Guam in the US House of Representatives, stated on 3 June 1998 that:

“...Through the irresponsible actions of both India and Pakistan, two more nations of the world have declared themselves nuclear weapons states. In the course of these critical two weeks, our planet has returned towards the days of nuclear peril, the likes of which have not been seen since the most tense days of the Cold War... I ask all my colleagues to join me in sending India and Pakistan a strong message of disapproval and to support the President in his use of economic and military sanctions. ${ }^{, 372}$

September 1999 [online] Available at: http://www.frontline.in/static/html/fl1618/16180310.htm [Accessed 28.03.2017]. and Noorani, A.G. (2002). The Truth about the Lahore Summit. Analysis. Frontline, Volume 19 Issue 4, 16 February - 1 March 2002 [online] Available at: http://www.frontline.in/static/html/fl1904/19040850.htm [Accessed 23.03.2017].

${ }^{370}$ RAND (Research AND Development) is an American nonprofit think tank.

${ }^{371}$ Congressional Record - Extension of Remarks. Think Tank Predicts Nuclear War Between India and Pakistan, Dan Burton, the US House of Representatives. 23 April 1998, p. E660 [online] Available at: http://www.gpo.gov/fdsys/pkg/CREC1998-04-23/pdf/CREC-1998-04-23-pt1-PgE660-4.pdf [Accessed 28.03.2017].

${ }^{372}$ US House of Representatives Congressional Record. India and Pakistan's Recent Nuclear Detonations testimony by Robert Underwood. 3 June 1998, H54 [online] Available at: http://www.gpo.gov/fdsys/pkg/CREC-1998-06-03/pdf/CREC-1998- 
In this hearing, the combined elements of a sense of nuclear danger posed to the world and call to implement economic and military sanctions against the nuclearization of South Asia can be detected. On 24 June 1999, during the Kargil war, US Senator from Nebraska Bob Kerrey gave the testimony below:

"There is a danger in not watching and paying attention to what is going on between India and Pakistan, and there is a danger that our lack of attention to this particular problem could produce a confrontation that not only would be deadly but would draw in the rest of the world as well...unlike the United States and the Soviet Union that over the last 50 years developed protocols to deal with nuclear weapons - and we have fairly substantial impressive margins for error-there have been no such discussions between India and Pakistan. Both of them are nuclear powers. Both of them could detonate nuclear weapons and use nuclear weapons in a confrontation of this kind. "373

Here, Senator Kerrey pointed out that the threat stemming from an Indo-Pakistani conflict poses a danger not only to the region, but also to rest of the world. Moreover, he underlined that the danger of a nuclear catastrophe was more acute in the Indo - Pakistani context than for the US and Soviet Union during the Cold War. There was no institutionalization of the nuclear relationship between India and Pakistan, as had been the case during the Cold War between the US and the Soviet Union.

These hearings reveal the anxiety felt in the US Congress regarding the nuclear dimension of the crisis in South Asia. The uneasiness in the Congress might have also influenced Clinton administration's active mediation efforts during the conflict. In late May, for example, the Assistant Secretary of State for South Asian Affairs Karl Frederick Inderfurth and the Undersecretary of State for Political Affairs Thomas Pickering met with Indian and Pakistani ambassadors in Washington, and conveyed the message that Pakistan should withdraw from the Indian side of the Line of Control. US Secretary of State Albright then called Pakistani Prime Minister Sharif and US General Tony Zinni called Pakistani General Musharraf, who he had a good relationship. ${ }^{374}$

Clinton sent letters to Sharif and Vajpayee, and clarified that Pakistani withdrawal is a precondition if Pakistan expected the US mediation. Clinton then called two leaders in mid-June to highlight this point. ${ }^{375}$ In late June, Clinton called Sharif again and rejected the Pakistani claim that the fighters were separatist guerrillas. Clinton also pointed out that the US believes that Pakistan is

06-03-pt1-PgH4030.pdf [Accessed 28.03.2017].

${ }^{373}$ US Senate Congressional Record. India and Pakistan Testimony given by Senator Bob Kerrey, 24 June 1999, S7679 [online] Available at: http://www.gpo.gov/fdsys/pkg/CREC-1999-06-24/pdf/CREC-1999-06-24-pt1-PgS7679-3.pdf [Accessed 29.03.2017].

374 Bruce, R. (2009). American Diplomacy and the 1999 Kargil Summit at Blair House in Peter R. Lavoy (ed.) Asymetric Warfare in South Asia: The Causes and Consequences of the Kargil Conflict. New York: Cambridge University Press, p. 134.

375 Talbott, S. (2004). Engaging India: Diplomacy, Democracy, and the Bomb. Washington DC.: Brookings Institution Press, p. 158. 
the aggressor. ${ }^{376}$ Clinton then sent the Commander in Chief of the US Central Command General Anthony Zinni to the region. Zinni visited Pakistan and met with the Prime Minister Sharif and General Musharraf on 24 and 25 June 1999. He sent a stark message to Pakistan that "if you do not pull back, you are going to bring war and nuclear annihilation down on your country. That's going to be very bad news for everybody." 377 After that, the US Deputy Assistant Secretary of State, Gibson Lanpher, visited New Delhi. He shared the same message conveyed by Zinni to Pakistan, that both parties should consider mitigating the crisis. Lanpher emphasized that India should not have reservations because Zinni had also asked Pakistan to withdraw troops from Kargil, and treat the crisis and the Kashmir problem as separate issues. ${ }^{378}$

Sharif was extremely concerned about the situation. He flew to the US to talk with Clinton. On 4 July 1999, Clinton met with Sharif. During the meeting, Clinton made pressure on Sharif to withdraw Pakistani troops from the Indian side of the Line of Control, and stated that only after that the US could mediate the conflict. Sharif accepted the US condition, in return Clinton promised to take a personal interest in the conflict and encourage bilateral talks between India and Pakistan. ${ }^{379}$

After these mediations, Sharif offered a peace agreement to India. India first rejected, but then accepted, and the crisis ceased. The Kargil crisis continued to be discussed in the US Congress even after the crisis ended. Bill McCollum, a Representative from Florida in the House of Representative, asserted on 29 July 1999 that not punishing Pakistan could encourage other states to acquire nuclear weapons. He also criticized Clinton by saying that:

"By stressing the imperative for a "face saving" exit for Nawaz Shariff, the Clinton Administration in effect went along with Islamabad's lies - thus covering up Islamabad's rouge-state actions. The Clinton administration in essence rewarded Pakistan for its aggression and nuclear blackmail, as well as blatant violation of previously signed international agreements. ${ }^{, 380}$

This statement is pro-Indian and blames Pakistan for the Kargil conflict. It came from a Republican Representative to the House of Representatives, and could therefore be political and denunciatory of Clinton's efforts in easing the crisis. However, he still call attention to the seriousness of the crisis and its possible consequences on the world altogether.

\footnotetext{
${ }^{376}$ Ibid. p. 159.

${ }^{377}$ Clancy, T., Zinni, T., and Koltz, T. (2004). Battle Ready. The US: G.P. Putnam's Sons, and Sidwick \& Jackson an imprint of a London: Pan Macmillan Ltd p. 347.

${ }^{378}$ C. Raja Mohan "Pak Must Pull Out Troops". Hindu, 28 June 1999 in Sumit Ganguly and S. Paul Kapur (eds.) (2009). Nuclear Proliferation in South Asia: Crisis behavior and the bomb. The USA and Canada: Routledge, Taylor\&Francis Group, p. 58.

${ }^{379}$ The American Presidency Project William J. Clinton Joint Statement With Prime Minister Nawaz Sharif on Pakistan on the Situation in Kashmir [online] Available at: http://www.presidency.ucsb.edu/ws/?pid=57835 [Accessed 31.03.2017]. and Talbott, S. (2004). Engaging India, p. 168.

${ }^{380}$ Congressional Record. After Kargil - What?, Hon. Bill McCollum of Florida in the House of Representatives Thursday. 29 July 1999, E1694-E1695 [online] Available at: https://www.congress.gov/crec/1999/07/30/CREC-1999-07-30-pt1-PgE16943.pdf [Accessed 28.03.2017].
} 
Director for South Asia at the Center for Strategic and International Studies (CSIS) $)^{381}$ Teresita Schaffer also made a testimony on 20 October 1999 in the US House of Representatives. She stated that:

"To me, the Kargil episode demonstrated two things: one, that India and Pakistan really do not want a nuclear confrontation; and two, that it would be easy to slip into one by accident. This makes a compelling case for increasing the margin of safety through risk reduction measures between those two. ",382

This testimony from Shaffer demonstrates the need to build risk reduction measures. It also indicates that without outside mediation, India and Pakistan are inclined to make mistakes with catastrophic consequences.

David Edward Bonior, a Representative in the US House of Representatives from Michigan and Democratic Whip, gave testimony on 12 July 2000 in the US House of Representatives, almost one year after the Kargil conflict. It highlighted that a continual involvement by the US in the region is needed because of the danger of nuclear conflict and terrorism. He stated that:

"Now we have an obligation to do our part to help establish stability in South Asia, and it is in our interest to do so. The threat of nuclear conflict and terrorism in South Asia is very real. We must reduce this threat and halt the arms race in South Asia, but I believe that unless Kashmir is addressed, Mr. Chairman, no real progress can be made. If we turn our attention away from the region as we did after the war in Afghanistan, we risk further erosion, violence, and disillusionment. We are uniquely positioned as a longstanding ally of Pakistan and as an emerging friend of India to bring the parties together. Given the stake in South Asia, punitive economic sanctions are clearly counterproductive. "383

These Congressional Hearings demonstrated that the US Congress took the crises between India and Pakistan seriously.

\subsubsection{Russian Mediation of 1999 Kargil War}

In the Kargil crisis, Pakistan actively sought to open a dialogue with Russia. It was obvious that Pakistan would not receive any active Russian support. Nonetheless, it aspired to at least hinder the overtly Russian support of India. For this reason, Pakistani Prime Minister Nawaz Sharif sent a diplomatic envoy led by H.M. Kasuri to Moscow. Kasuri explained the Pakistani position, was not able to secure Russian support. Quite the contrary, he found that Russia supported India. Russia declared that groups backed by Pakistan triggered the crisis by infiltrating the Line of Control.

\footnotetext{
${ }^{381}$ CISIS is an American think tank based in Washington, D.C. in the US.

${ }^{382}$ US House of Representatives Hearing Before the Committee on International Relations. 20 October 1999, testimony held by Ms. Teresita Schaffer, p. 33 [online] Available at: http://www.gpo.gov/fdsys/pkg/CHRG-106hhrg61551/pdf/CHRG-106hhrg61551.pdf [Accessed 28.03.2017].

${ }^{383}$ US House of Representative Hearing on Global Terrorism. South Asia - The New Locus. 12 July 2000, Testimony held by Representatives David E. Bonior p. 6. [online] Available at: http:/www.gpo.gov/fdsys/pkg/CHRG-106hhrg68482/pdf/CHRG106hhrg68482.pdf [Accessed 28.03.2017].
} 
Learning this was backlash for Pakistan as Russia's position was indeed consistent with what India had claimed. Pakistan also pled for an active Russian mediation of the crisis. However, Russia responded that it could only intervene under the condition that the mediation request comes from both sides of the conflict. Russia added that a realistic solution could only be achieved through a direct dialogue between India and Pakistan. ${ }^{384}$

Moreover, Russia’s Deputy Foreign Minister, Grigory Karasin requested that Pakistan draw the infiltrators back out of the LOC. It was clearly support for Indian claims. ${ }^{385}$ Russia also tried to influence Pakistan through its embassy in Islamabad and warned Pakistan that it should immediately withhold. ${ }^{386}$

Russia was pro-India in the Kargil conflict. However, this position was consistent with both the US and even with the Chinese responses to the conflict. They both supported India to a degree that even surprised India itself. ${ }^{387}$ Therefore, the Russian reaction to the Kargil crisis was not divergent from the global community. For example, the G-8 also expressed its concern and stated that infiltration of armed intruders violating the Line of Control was the main reason of the Kargil Conflict. ${ }^{388}$ This statement from the G-8 also supported India's stance to the conflict.

\subsubsection{Chinese Mediation of the 1999 Kargil War}

In the 1999 Kargil crisis, China did not play an active role. It stayed neutral and encouraged both sides to engage in dialogue. This Chinese attitude in the 1999 Kargil crisis overlaps with the China's response to the 1990 Kashmir crisis. This finding strengths the assumption that after the Cold War, China pursued a passive role in the crises in South Asia. For example, on 10 June 1999, the Chinese Foreign Ministry stated that China hoped that the crisis would be solved through negotiations between India and Pakistan. ${ }^{389}$ It did not specify any particular role that China could play. Pakistan was not satisfied with this statement by China. What Pakistan needed was not the China's neutrality, but China's support. Hence, Pakistan wanted to influence China and on 11 June 1999, the Foreign Minister of Pakistan Sartaj Ali met with Chinese Foreign Minister Tang Jiaxuan.

\footnotetext{
${ }^{384}$ Dutt, V.P. (2001). Indo-Russian Relations: An Overview in V.D. Chopra (edt.) Indo-Russian Relations: Prospects, Problems and Russia Today. India: Kalpaz Publications, p. 33.

${ }^{385}$ Schofield, V. (2003). Kashmir in Conflict: India, Pakistan and the Unending War. New York and London: I.B. Tauris $\&$ Co Ltd., p. 214.

386 The Hindu (1999). Russia Rejects Pakistan Version of Kargil Crisis. 2 July 1999, in Peter R. Lavoy (edt.) Asymetric Warfare in South Asia: The Causes and Consequences of the Kargil Conflict. New York: Cambridge University Press, 2009. p. 199.

${ }^{387}$ Tellis, A.J., Fair, C.C., Medby, J.J. (2001). Limited Conflicts under the Nuclear Umbrealla: Indian and Pakistani Lessons from the Kargil Crisis: CA: RAND Corp Santa Monica, pp. 21-22.

${ }^{388}$ G8 Information Center (1999). G8 Statement on Regional Issues, Köln, Germany, 20 June 1999 [online] Available at: http://www.g8.utoronto.ca/summit/1999koln/regional.htm\#top [Accessed 28.03.2017].

389 Dawn (1999). China Urges Negotiations. 11 June 1999, Karachi cited in Rashid Ahmed Siddiqi (2014). China`s Evolving Posture in South Asia: Some Reflections IPRI Journal (2014) Vol. XIV, No. 2, Summer 2014: 1-19, p. 6 [online] Available at: http://www.ipripak.org/wp-content/uploads/2014/10/1-article-s14.pdf [Accessed 28.03.2017].
} 
However, Jiaxuan gave exactly the same message that was released one-day before by the Chinese Foreign Ministry. He told to Ali that only India and Pakistan could solve their problems through peaceful means. ${ }^{390}$ He refrained from making any commitments to support Pakistan or taking up a mediator role in the conflict.

Then Chairman of the Committee of the Chinese People's Congress Le Peng also met with Ali. During the meeting Peng told Ali that both Pakistan and India are important countries in South Asia, and China sincerely hopes that they would prevent the Kashmir situation from getting out of the control. ${ }^{391}$ This statement from Peng also did not satisfy Pakistan's expectations from how they could engage China.

A spokesman of the Chinese Foreign Ministry, Zhu Bangzao, also stated that:

"China hopes India and Pakistan will exercise restraint and peacefully resolve their differences and problems through patient and sincere dialogue."

This statement above exhibited that China was not willing to mediate, which was representative of Chinese foreign policy pattern at that period. China's position during the 1999 Kargil crisis was very different from its attitudes in the crises before the 1980s. China's unwillingness to support Pakistan was also declared to the Pakistani General Musharrraf in his state visit to China. China warned Musharraf that engaging an open conflict with India was not a wise decision. He also informed Musharraf that China ultimately predicted that Pakistan would have to back down. ${ }^{393}$

These messages sent by China demonstrated failed Pakistani attempts to obtain Chinese support. This Chinese attitude meets the criteria of Expectation 4 because China did not try to prevent the mediation attempts of the US. Moreover, it refrained from singling out a party to blame, contrary to the crises before 1980s where China had persistently blamed India for initiating the crises. These Chinese actions also meet the criteria of Expectation 5 that Pakistan tried to align itself with China, but China rejected Pakistan.

Analysis of the Kargil War demonstrated that the nuclear dimension of the conflict was important for the major powers. The mediation carried out by US President Bill Clinton demonstrates the importance that the US gave to the crisis. The crucial factor was Russia and China's rejection of

\footnotetext{
${ }^{390}$ Xinhua News Agency (1999). China Says It Hopes for Political Solution to Kashmir Issue. 11 June 1999, NEXIS.

${ }^{391}$ Xinhua News Agency (1999). Today’s Diplomatic News Highlights, 11 June 1999, Nexis.

392 The Pioneer (1999). Show Restraint: China, 28 May 1999; The Hindu (1999). Resume Talks, China Tells Sharif. 29 June 1999; and The Pioneer (1999). Kashmir Is Not Kosovo. 30 May 1999 in Tellis, A.J., Fair, C.C., Medby, J.J. (2001). Limited Conflicts under the Nuclear Umbrella: Indian and Pakistani Lessons from the Kargil Crisis. Santa Monica, CA: RAND Corp, p. 21.

${ }^{393}$ Siddique-ul-Farooque, M. (2006). Kargil: Adventure or trap: White Paper. Lahore: Sagar Publishers, p. 32.
} 
the demand of Pakistani foreign minister Sartaj Ali and Pakistani General Musharraf for support. The joint stance by Russia and China to support neither of the conflicting parties facilitated Clinton's mediation efforts. This shows the role of the collaborative mediation by the US, Russia, and China to ease the crisis. The analysis based on only pivotal deterrence would only indicate US mediation and left the reactions from Russia and China to US mediation unexplored. Here, I identified the Pakistani attempts to secure support from both Russia and China at the height of the crisis. I have demonstrated that Russia and China's rejections of Pakistani demands during the crisis isolated Pakistan and made it more amenable to US mediation. Therefore, it is necessary to analyze the interaction of Russia and China in relation to the mediation efforts of the US. Identifying the collaboration between the US, Russia, and China is especially interesting because the US was busy with the NATO air campaign in Kosovo at the same time. Russia and China had positions differing from the US regarding Kosovo. One would expect that China and Russia would prolong the conflict by supporting either India or Pakistan; thereby preoccupying the US and weakening its position in Kosovo. However, the nuclear dimension of the conflict in South Asia did not allow the play of power politics. These actions of the mediator states in the 1990 Kashmir and the 1999 Kargil Crisis met Expectation 4: collaboration and Expectation 5: collaborative mediation places pressure on the sides of the conflict.

The case also demonstrated that the interaction between Russia, China and the US is not institutionalized based on high-level cooperation, as collective actor deterrence would argue. Rather is loosely organized and mainly involves not hindering the mediation attempt of each other. It has, however, an influence on the success of mediation, which makes it necessary to analyze.

The President of Pakistan Shariff also used international mediation as a tool to withdraw from the conflict. Sharif was in a difficult position vis-à-vis the Pakistani military. A failure in a national security issue would seriously harm Sharif and cause him to lose his position. ${ }^{394}$ Sharif therefore used the mediation of Clinton, and highlighted that Clinton would continue to show interest in the conflict. Sharif thought highlighting the success of the Clinton mediation could reduce the domestic pressure. Therefore, the move of Sharif fits Expectation 6.

\subsubsection{Attacks on the Indian Parliament in 2001 and the Military Standoff}

\subsubsection{Overview}

After the Kargil War ended, relations between India and Pakistan did not immediately normalize. The military coup by Pervez Musharraf in October 1999 worsened the already tense relations. Despite these tense relations, there were no major incidents until the fall of 2001. On 1

\footnotetext{
${ }^{394}$ Clancy, T., Zinni, T., and Koltz, T. (2004). Battle Ready, p. 347.
} 
October 2001, the Legislative Assembly in the Indian-controlled State of Jammu and Kashmir were attacked by a group of insurgents masquerading as police officers by using a hijacked official vehicle loaded with explosives. A Pakistan-based insurgent group, Jaish-e-Mohammed, claimed responsibility for the attack. ${ }^{395}$ Although this incident put India under pressure to show its strength in the Kashmir region, the real shock came when the Parliament of India in New Delhi was attacked on 13 December 2001. The Indian government blamed the Pakistani based Lashkar-e-Tayyiba (LeT) for being responsible for the attack, noting Pakistani involvement as well. ${ }^{396}$ An attack on a symbol of Indian democracy was a huge test for the relations between India and Pakistan under a nuclear context. The plan was to attack in the morning session of the Parliament, which was attended by the Prime Minister and other senior government leaders. Two lucky incidents prevented the attack from taking place. First, the attackers' car crashed into an official car. They had to therefore continue on foot. Second, the parliamentary session was on a break at the time of the attack. The militant who was responsible for notifying the attackers by mobile phone about the time of the sessions of the Parliament was unaware of the break because there was a power outage in New Delhi preventing the broadcasting of the parliamentary sessions. ${ }^{397}$ If the attack had been successful, there was a possibility that most of the important decision makers in the Indian government would have been killed, including the Prime Minister. An attack on Indian Parliament was therefore against the assumptions of incremental escalation. Nuclear deterrence theories would not expect a huge provocation on this scale in the first stages of the conflict, which can seriously damage the stability at the nuclear level. In the absence of international mediation, devastating consequences would follow, because the crisis had already started at a very high level, providing limited room for India and Pakistan for further escalation.

India claimed that the Pakistani secret service I.S.I. (Inter-Services-Intelligence) was funding violent Islamic groups on the Indian side of Kashmir since the 1980s. This belief led the Cabinet Committee of India to give a serious warning to Pakistan. The then Indian Prime Minister

\footnotetext{
395 Bearek, B. (2001). A Nation Challenged: Repercussions; 26 Die as Suicide Squad Bombs Kashmir Legislative Building The New York Times, 2 October 2001 [online] Available at: http://www.nytimes.com/2001/10/02/world/nationchallenged-repercussion-26-die-suicide-squad-bombs-kashmir-legislative.html [Accessed 23.03.2017].

${ }^{396}$ Chandrasekaran, R. and Lakshmi, R. (2001). "New Delhi Lays Blame; India Implicates Militants in Attack But Struggles to Prove a Pakistani Role." Washington Post, 29 December 2001, A-1, and Lakshmi, R. (2001). "Indians Blame Attacks on Pakistan-Based Group." Washington Post, 15 December 2001, A-23, both cited in Nayak, P and Krepon, M. (2006). US Crisis Management In South Asia's Twin Peaks Crisis The Henry L. Stimson Center, Report 57, September 2006, p. 15. [online] Available at: https://www.stimson.org/sites/default/files/file-attachments/Twin_Peaks_Crisis.pdf [Accessed 22.03.2017].

${ }^{397}$ Dugger, C. (2001). India Weighs Using Troops to Hunt 2 Groups in Pakistan. New York Times, 23 December 2001, A-4 and Lakshmi, R. (2001). Gunmen With Explosives Attack Indian Parliament. Washington Post, 14 December 2001 , A-1 both are cited in in Nayak, P and Krepon, M. (2006). US Crisis Management In South Asia's Twin Peaks Crisis. The Henry L. Stimson Center, Report 57, September 2006, p. 15.
} 
Atal Bihari Vajpayee ordered the country's armed forces to mobilize for war. ${ }^{398}$ India sent 800,000 troops to its western border. It also activated its air force units and satellite airfields, and additionally moved its Easter fleet from the Bay of Bengal to the Arabian Sea to block Pakistan. Pakistan also deployed its troops along the border, bringing the danger of escalating the conflict to a nuclear level conflict that may have been triggered by just a single incident or misunderstanding. ${ }^{399}$

Indian military deployments at the border compelled Pakistan to freeze the accounts of Lashkar-e-Taiba and to arrest fifty Islamic militants toward the end of December $2001{ }^{400}$ India, however, was not satisfied with this Pakistani measure. New York Times reporters Burns and Dugger reported that the spokeswoman for India's Ministry of External Affairs Nirupama Rao demanded more information about the arrests made by Pakistan. Based on the observations of Pakistani officials, Burns and Dugger also reported that India brought seven divisions into attack positions near the Pakistani border. ${ }^{401}$ The most concerning development was that there were some reports claiming that Indian military opted for enlarging the scope of the deployment, and considered launching limited offensives against training camps on Pakistan's side of Kashmir. ${ }^{402}$ This caused a great concern at the international level because India and Pakistan did not cross the LOC after the nuclearization of the conflict, even in the 1999 Kargil war. Nuclear deterrence theory would assume that there was no need for international mediation because India and Pakistan would limit the conflict anyways, and India would not cross the LOC. However, the increasing threatening tone of Indian and Pakistani politicians put the main assumption of nuclear deterrence under pressure, and brought international mediation to deescalate the conflict. On 2 January 2002, for example, Prime Minister Vajpayee stated that "no weapon would be spared in self-defense. Whatever weapon was available would be used no matter how it wounded the enemy." 403 Here, one can detect the underlying threat of using even nuclear weapons. On 11 January 2002, Indian Army

\footnotetext{
${ }^{398}$ Coll, S. (2006). The Stand-Off: How jihadi groups helped provoke the twenty-first century's first nuclear crisis. The New Yorker. 13 February 2006 [online] Available at: http://www.newyorker.com/magazine/2006/02/13/the-stand-off [Accessed 23.03.2017].

${ }^{399}$ Chari, P.R. (2003). Nuclear Crisis, Escalation Control, and Deterrence in South Asia. The Henry L. Stimson Center, Working Paper, Version 1.0, August 2003, p. 20. [online] Available at: http://www.stimson.org/sites/default/files/fileattachments/escalation_chari_1_1.pdf [Accessed 17.08.2016].

400 Burns, J.F. (2001). Pakistan Moves Against Groups Named by India. The New York Times, 29 December 2001 [online] Available at: http://www.nytimes.com/2001/12/29/world/pakistan-moves-against-groups-named-by-india.html [Accessed 23.03.2017].

401 Burns, J.F. and Dugger, C.W. (2001). India Builds Up Forces as Bush Urges Calm. The New York Times, 30 December 2001 [online] Available at: http://www.nytimes.com/2001/12/30/world/india-builds-up-forces-as-bush-urgescalm.html [Accessed 23.03.2017].

${ }^{402}$ Gupta, S. (2002). When India came close to war. Twice in 2002, India was on the verge of striking against Pakistan. India Today, 23 December 2002. [online] Available at: http://indiatoday.intoday.in/story/twice-in-2002-india-was-onthe-verge-of-striking-against-pakistan/1/218109.html [Accessed 28.03.2017].

${ }^{403}$ Shukla, J.P. (2002). No Weapon will be Spared for Self-Defence: PM. The Hindu, 3 January 2002 [online] Available at: http://www.thehindu.com/thehindu/2002/01/03/stories/2002010303010100.htm [Accessed 23.03.2017].
} 
Chief General S. Padmanabhan announced that the Indian armed forces completed their mobilization and waited for a positive signal from political leadership. ${ }^{404}$

Increasing tensions compelled Pakistani President Musharraf to make some concessions. On 12 January 2002, on national television, Musharraf denounced religious extremism and banned jihadi groups from Pakistan, including Lashkar-e-Taiba and Jaish-e-Muhammad. Although Musharraf highlighted Pakistan's continuing moral support for Kashmir's liberation, he described the attack on the Indian Parliament as a terrorist act. ${ }^{405} \mathrm{He}$ also declared that "no organization will be allowed to perpetuate terrorism behind the garb of the Kashmiri cause." ${ }^{406}$ Although the television speech of Musharraf helped reduce the tension, India had some doubts about Musharraf's intentions. India also highlighted that there was heavy snow during the winter in the region, not letting the insurgent activities take place anyways. It was therefore better to wait until April and May to see whether terrorist activities would reoccur and increase. ${ }^{407}$ Moreover, Musharraf had detained 2.000 people as Islamic radicals. He later set approximately 70 percent of them free again, only contributing to the doubts by India about the real intention of Pakistan. ${ }^{408}$ Therefore, India maintained its military units along the LOC. Additionally, India tested a ballistic missile ${ }^{409}$, causing Pakistani President Musharraf to issue a nuclear threat. Musharraf even declared that the use of nuclear weapons was a possibility if the pressure on Pakistan became too great. ${ }^{410}$

The second most dramatic point of the crisis began with the massacre of families of Indian soldiers on 14 May 2002 in a military base in Kaluchak, Jammu. ${ }^{411}$ This led some Indian decisionmakers to reconsider crossing the Line of Control, and initiate an offensive against the Pakistanheld parts of Kashmir. ${ }^{412}$ Even if the offensive was considered to be a conventional attack, the objectives were no longer limited, which posed the danger of escalating the conflict to a nuclear

\footnotetext{
${ }^{404}$ Sood, V.K. and Sawhney, P. (2003). Operation Parakram: The War Unfinished. New Delhi: Sage Publications, p. 59. 405 Coll, S. (2006). The Stand-Off. The New Yorker, 13 February 2006.

${ }^{406}$ Mydans, S. (2002). Musharraf Treading Gently Against Pakistani Militants. The New York Times, 28 April 2002 [online] Available at: http://www.nytimes.com/2002/04/28/world/musharraf-treading-gently-against-pakistani-militants.html?_r=0 [Accessed 28.03.2017].

${ }^{407}$ Nayak P. and Krepon, M. (2006). US Crisis Management in South Asia's Twin Peak Crisis, p. 18.

${ }^{408}$ Mydans, S. (2002). Musharraf Treading Gently Against Pakistani Militants. The New York Times, 28 April 2002.

${ }^{409}$ Chengappa, R. (2002). Future Fire: The Shorter, Smarter Agni Heralds a New Genre of Missiles Directed Towards Pakistan. India Today, 11 February 2002 [online] Available at: http://indiatoday.intoday.in/story/shorter-smarter-agniheralds-new-genre-of-missiles-directed-towards-pakistan/1/220437.html [Accessed 28.03.2017].

${ }^{410}$ Interview done by Der Spiegel with Pervez Musharraf Spiegel Online Pakistans Musharraf droht Indien mit der Atombombe 05.04.2002 [online] Available at: http://www.spiegel.de/politik/ausland/kaschmir-konflikt-pakistans-musharrafdroht-indien-mit-der-atombombe-a-190389.html [Accessed 23.03.2017].

${ }^{411}$ Bokhari, F. and Luce, E. (2002). Bombers Kill 33 in Kashmir as US Envoy Visits India. Financial Times, 15 May 2002 and Ministry of External Affairs Government of India. Documents, Kaluchak Massacre. 14 May 2002 [online] Available at: http://mea.gov.in/in-focus-article.htm?18990/Kaluchak+Massacre+14+May+2002 [Accessed 23.03.2017].

${ }^{412}$ Chengappa, R. and Gupta, S. (2002). In Striking Distance. Vajpayee sounds war cry, India prepares for limited military offensive against Pakistan. India Today, 3 June 2002 [online] Available at:

http://indiatoday.intoday.in/story/vajpayee-sounds-war-cry-india-prepares-for-limited-military-offensive-againstpakistan/1/221339.html [Accessed 24.03.2017].
} 
level. The situation deteriorated when Pakistan tested surface-to-surface ballistic missiles on the dates of 25, 26 and 28 May 2002. ${ }^{413}$ The nuclear dimension of the tests became clearer when Pakistan's Ambassador to the UN, Munir Akram, discussed the use of nuclear weapons in a news conference, and declared that Pakistan could not accept "no first use" policy. ${ }^{414}$

The nuclear threats issued by Pakistani and Indian politicians combined with the considerations of enlarging the military operations along and beyond the LOC show the importance of international mediation as a complementary measure to support the direct deterrence between India and Pakistan. For this reason, the US sent a special envoy to ease the increased tension. ${ }^{415}$ After the arrival of the US envoy, the tension started to decline, but India still kept its troops on the front line until October 2002. It then announced that it would withdraw its troops from the border even though cross-border terrorism was continuing and Pakistan did not extradite the criminals India wanted. Nevertheless, the Indian government claimed that it had reached its goals, because President Musharraf confessed Pakistan's support of separatist groups in Kashmir and promised to confine the activities of radical Islamic groups within Pakistan. ${ }^{416}$

Although the crisis had ended, some post-conflict statements of high-level politicians raised doubt as to India and Pakistan were really affected by the nuclear aspect of the conflict. The severity of these statements endorse the importance of international mediation in overcoming misunderstandings. For example, on 30 December 2002 after the crisis ended, President Musharraf said that he would have unleashed an "unconventional war" on India had a single Indian soldier crossed the border." In response, George Fernandes assured him that "there will be no Pakistan left" if India used its nuclear weapons. Pakistan followed by warning India of "an unforgettable reply" besides accusing it of "sick war hysteria." 417 Below, I analyze the mediation of major powers in detail.

\footnotetext{
${ }^{413}$ Subramanian, T.S. (2002). Missile Maneuvers. Frontline, Cover Story, Volume 19, Issue 2, 8-21 June 2002 [online] Available at: http://www.frontline.in/static/html/fl1912/19120200.htm [Accessed 24.03.2017].

${ }^{414}$ Haider, M. (2002). Islamabad refuses to accept 'no first strike' doctrine. Dawn [online] Available at: https://www.dawn.com/news/38860/islamabad-refuses-to-accept-no-first-strike-doctrine [Accessed 24.03.2017].

${ }^{415}$ This is a special envoy led by the then US Deputy Secretary of State Richard Armitage. I will explain the function of this envoy later in the US Mediation part.

${ }^{416}$ Chari, P.R. (2003). Nuclear Crisis, Escalation Control, and Deterrence in South Asia, p. 22.

${ }^{417}$ Bidwai, P. (2003). Nuclear South Asia: Still on the Edge. Frontline, Vol. 20, Issue 02, 18 January 2003 [online] Available at: http://www.frontline.in/static/html/fl2002/stories/20030131007211600.htm [Accessed 13.08.2016], and BBC News (2003). India Warning over Nuclear War, 7 January 2003 [online] Available at: http://news.bbc.co.uk/2/hi/south_asia/2636157.stm [Accessed 28.03.2017].
} 


\subsubsection{US Mediation of the Crisis}

In 2001, the US was essentially occupied with its campaign against terrorism in Afghanistan. However, the attack on Indian Parliament drew US attention. On 14 December 2001, US President Bush called Pakistani President Musharraf and India’s Prime Minister Vajpayee and urged them to stay calm. ${ }^{418}$ Threatening statements from Indian and Pakistani leaders was concerning for the US Congress, where the nuclear dimension of the crisis was salient. For example, Samuel R. Berger, the former National Security Advisor, testified in the US Senate stating that:

“...Our objective must not be only to destroy the terrorist networks that have attacked and threatened us; we must do so in a way that makes the world more stable, not less, that isolates the extremists, not us...It means supporting the administration's active role in diffusing the crisis between Pakistan and India, where confrontation can lead to miscalculation and with nuclear weapons on both sides, miscalculation can lead to disaster. "419

In his testimony, Berger linked the crisis in South Asia with the US's own campaign against terrorism. He added that instability strengthens the terrorism. The conflicts between India and Pakistan also destabilized the region and contributed to the growth of terrorism. Additionally, the conflict between India and Pakistan also has a nuclear dimension with devastating effects. Therefore, Berger advocated the active US involvement in mediating the crisis.

George Tenet, the then director of the CIA, also underlined the danger of nuclear escalation in the region. He stated that:

"With regard to India and Pakistan, Mr. Chairman, we have been very concerned subsequent to the attack on the Indian Parliament in December about the instability that has been created. The chance of war between these two nuclear-armed states is higher than at any point since 1971. If India were to conduct large-scale offensive operations into Pakistani Kashmir, Pakistan might retaliate with strikes of its own in the belief that its nuclear deterrent would limit the scope of an Indian counterattack. Both India and Pakistan are publicly downplaying the risks of nuclear conflict in the current crisis. We are deeply concerned however, that a conventional war once begun could escalate into nuclear confrontation., 420

Tenet clearly states that CIA took the conflict between India and Pakistan very seriously. This statement exhibits Tenet's belief that a conventional crisis could easily escalate to a nuclear level, despite the nuclear deterrence between parties of the conflict.

The nuclear dimension of the crisis became clear in the US Department of State as well when India tested its new generation ballistic missiles in the beginning of February 2002. The range of ballistic missiles was $700 \mathrm{~km}$, which could have been directed against Pakistan as the only possible

\footnotetext{
${ }^{418}$ Nayak P. and Krepon, M. (2006). US Crisis Management in South Asia's Twin Peak Crisis, p. 24.

${ }^{419}$ US Senate Hearing Before the Committee on Foreign Relations. What is Next in the War on Terrorism? S. HRG. 107-417, p. 10. [online] Available at: http://www.gpo.gov/fdsys/pkg/CHRG-107shrg78906/pdf/CHRG-107shrg78906.pdf [Accessed 28.03.2017].

${ }^{420}$ US Senate Hearing Before the Committee on Armed Services. S. HRG. 107-765, 19 March 2002, p. 5 [online] Available at: http://www.gpo.gov/fdsys/pkg/CHRG-107shrg82913/pdf/CHRG-107shrg82913.pdf [Accessed 28.03.2017].
} 
target. ${ }^{421}$ New Yorker columnist Steve Coll wrote in his article that Richard Armitage, the US Deputy Secretary of State, told him that he was absolutely convinced that Pakistan's generals would use nuclear weapons if the Indian army continued to use force against Pakistan. ${ }^{422}$ This statement shows that senior executives in the Bush administration took the crisis seriously, and did not rely on nuclear stability between India and Pakistan.

These ominous developments caused US Secretary of State Colin Powell to telephone General Musharraf. Powell warned Musharraf to end Pakistan's military support for jihadi groups in Kashmir, ${ }^{423}$ likely paving way for Musharraf's speech on national television on 12 January 2002, which slightly reduced the tension. The crisis became stable until the Kaluchak Massacre in May 2002. After this massacre, the rhetoric of Indian and Pakistani politicians resumed a belligerent tone. The Indian Prime Minister Vajpayee even declared that military personnel should be ready for a decisive battle. ${ }^{424}$ Pervez Musharraf answered this threat by stating that:

"Any incursion by the Indian forces across the Line of Control, even by an inch, will unleash a storm that will sweep the enemy. "425

On 30 May 2002, George W. Bush declared that Pakistan must stop the infiltration of terrorists into India, and said that he would sent US Secretary of Defense Donald Rumsfeld to the region to defuse the tension between India and Pakistan. ${ }^{426}$ Additionally, in an effort to ease the crisis, US Deputy Secretary of Defense Paul Wolfowitz also met with India's defense minister, George Fernandes, in Singapore. Wolfowitz told Fernandes that the war would carry grave consequences and must be avoided. ${ }^{427}$

The tension between India and Pakistan was still high. Therefore, the US tasked Richard Armitage to go the region and mediate the crisis. Armitage arrived in Pakistan on 6 June and met with President Musharraf. By his own account to the New Yorker columnist Steve Coll ${ }^{428}$ Armitage

\footnotetext{
${ }^{421}$ Chengappa, R. (2002). Future Fire: The Shorter, Smarter Agni Heralds a New Genre of Missiles Directed Towards Pakistan. India Today, 11 February 2002 [online] Available at: http://indiatoday.intoday.in/story/shorter-smarter-agniheralds-new-genre-of-missiles-directed-towards-pakistan/1/220437.html [Accessed 28.03.2017].

${ }^{422}$ Coll, S. (2006). The Stand-Off. The New Yorker, 13 February 2006.

${ }^{423}$ Ibid.

${ }^{424}$ Left, S. (2002). Indian PM calls for `decisive battle` over Kashmir. The Guardian, 22 May 2002 [online] Available at: http://www.theguardian.com/world/2002/may/22/kashmir.india [Accessed 28.03.2017].

${ }^{425}$ The Hindu (2002). We'll Unleash a Storm: Musharraf. 30 May 2002, The Hindu [online] Available at: http://www.thehindu.com/2002/05/30/stories/2002053008180101.htm [Accessed 28.03.2017].

${ }^{426}$ The White House Presidential News and Speeches. President George W. Bush President to Send Secretary Rumsfeld to South Asia: Remarks by the President at Conclusion of Cabinet Meeting, The Cabinet Room. 30 May 2002 [online] Available at: https://georgewbush-whitehouse.archives.gov/news/releases/2002/05/20020530-1.html [Accessed 24.03.2017].

${ }^{427}$ Shanker, T. and Bumiller, E. (2002). Citing Tension, U.S. Advises Americans in India to Leave. The New York Times, 1 June 2002 [online] Available at: http://www.nytimes.com/2002/06/01/world/citing-tension-us-advises-americans-inindia-to-leave.html [Accessed 24.03.2017].

${ }^{428}$ The information about Armitage mission was taken from the New Yorker reporter Steve Coll's coverage of the event and his own contacts with the Richard Armitage and the then Indian National Security Advisor Brayesh Mishra.
} 
warned Musharraf that even if radical Islamist groups may be instrumental for Pakistan to exercise pressure on India now, these groups would be very dangerous on Pakistan in the long term. Musharraf assured him that "nothing is happening on the LOC." Armitage told Coll that it was enough for him because he was interested primarily in stopping the conflict, and not necessarily finding a long-term solution. In New Delhi, Armitage met with Prime Minister Vajpayee. He told Indians that President Musharraf promised President Bush that he would crack down on jihadists in Kashmir. The Indian National Security Advisor Brajesh Mishra told the reporter Coll that India interpreted Armitage's statement as a special message from Musharraf to India. Armitage told Indians that Pakistan needed India to also indicate that the crisis was ending. Indian Defense Minister George Fernandes suggested that India might move its naval vessels away from Pakistan. After that, Powell called Musharraf to buttress the Indian message showing its willingness to ease the conflict. ${ }^{429}$ The Pakistani President Musharraf publicly endorsed that it would hinder trans-border terrorism and fight against terrorist groups.

These US initiatives contributed to mitigating the crisis, which was more urgently needed than in the 1999 Kargil crisis. In the Kargil Crisis, direct communication between Indian and Pakistani decision makers had continued, even if it was through informal channels. In the 2001 crisis, there was no direct communication channel between India and Pakistan.

One would expect that the US should have sided with Pakistan because Pakistan was playing a key role in supporting US operations in Afghanistan. Nuclear deterrence theory also would not expect that the US would intervene because it is assumed that direct deterrence between India and Pakistan would prevent nuclear conflict anyways. Therefore, it was not necessary to risk offending an ally in the vital stage of the US campaign in Afghanistan. However, US attempts to control Pakistan's actions demonstrated that the US did not support Pakistan's actions simply because it was an ally. This US policy marks a shift in policy direction from the Cold War period when the US firmly supported Pakistan as an ally. One can attribute this difference to the nuclear dimension of the crisis. The nuclear dimension compelled the US to pursue policies easing the crisis instead of triggering it.

One can also attribute the balanced US policy to the US desire to build an equilibrium between its policies towards India and Pakistan. The US - India relations were, however, not strong in 2001, became stronger only after the signing of the US - India Civil Nuclear agreement in 2005.430

\footnotetext{
${ }_{429}$ Coll, S. (2006). The Stand-Off. The New Yorker, 13 February 2006.

${ }^{430}$ The White House Office of the Press Secretary. President George W. Bush Joint Statement Between President George
} 


\subsubsection{Russian Mediation of the Crisis}

In the 2001 crisis, Russia showed greater understanding of the Indian position. Nevertheless, it advocated for direct dialogue between India and Pakistan and argued that direct dialogue was the best option to solve the crisis. Right after the negotiations with the then Indian Prime Minister Atal Bihari Vajpayee, Vladimir Putin stated that:

“...We paid much attention to the situation in Southern Asia. Russia would like the emerging political dialogue between India and Pakistan to turn into a permanent constructive process... We welcome a direct dialogue between India and Pakistan and we very much hope that it will lead to positive results. "431

A pro-Indian statement came from the Russian Deputy Prime Minister Ilya Klebanov. BBC news reported that Klebanov visited India to arrange trade issues. In New Delhi, he stated that

"It is time for Pakistan to show it is serious about fighting terrorism...It is not enough to say words. Pakistan has to do something on the ground... ,432

He also underlined the unequivocal support of Russia for India. In the meantime, he emphasized that military assertiveness was not a good option. ${ }^{433}$ These statements demonstrate Russia's support for India. At a meeting of foreign ministers of the Shanghai Cooperation Organization, the Russian Foreign Minister Igor Ivanov underlined the seriousness of the crisis in South Asia and added that India and Pakistan should try to solve their problems calmly. He stated that:

"At our meeting in Beijing we together expressed concern over the continuing tensions between India and Pakistan...It is vital for India and Pakistan to show restraint and use their best efforts to solve existing problems peacefully. ",434

On 17 May 2002, in answering the question raised by the Russian News Agency, the official spokesman of the Foreign Ministry of the Russian Federation Alexander Yakovenko highlighted Russia's concern about a possible conflict between India and Pakistan. He stated that:

W. Bush and Prime Minister Manmohan Singh, 18 July 2005 [online] Available at: http:/georgewbushwhitehouse.archives.gov/news/releases/2005/07/20050718-6.html [Accessed 28.03.2017].

${ }^{431}$ President of Russia. Statement for the Press and Answers to Questions Following Negotiations with Indian Prime Minister Atal Bihari Vajpayee. 6 November 2001 [online] Available at: http://en.kremlin.ru/events/president/transcripts/21390 [Accessed 28.03.2017].

${ }^{432}$ BBC News. (2002). Russia Backs India Over Kashmir. 7 February 2002 [online] Available at: http://news.bbc.co.uk/2/hi/south_asia/1807238.stm [Accessed 27.03.2017].

433 Ibid.

${ }^{434}$ The Ministry of Foreign Affairs of the Russian Federation. 06 May 2002, Speech by Russian Foreign Minister Igor Ivanov at an Enlarged Meeting of Foreign Ministers of States-Participants in the Shanghai Cooperation Organization. [online] Available at:

http://www.mid.ru/en/web/guest/sanhajskaa-organizacia-sotrudnicestva-sos-/-/asset_publisher/0vP3hQoCPRg5/content/id/557702 [Accessed 31.03.2017]. 
"On May 14 a large-scale terrorist act was committed in the Indian State of Jammu and Kashmir which resulted in over fifty people killed and wounded from the Indian army military, their families and innocent residents... In Moscow we proceed from the assumption that in the current situation in the South Asian region, an open armed conflict is extremely undesirable, would have dire consequences for security and stability, going beyond the confines of that region. An extremely balanced approach to actions is required of both sides in this situation. At the same time, in terms of our own sad experience, we are well aware what terrorism is. We also understand the extreme concern of the Indian side over the continued terrorist activity by the extreme forces, apparently connected to some extent with the consequences of the anti-terrorist operation conducted in Afghanistan. We regard as just and absolutely legitimate the desire of the Indian side to put an end to the brazen activities of terrorists. We are prepared to assist this to the extent this is possible. We express solidarity with the legitimate demands of our Indian friends. ",435

Whereas Yakovenko in his statement declared the Russia's solidarity with India, he still emphasized that a possible conflict between India and Pakistan would have consequences beyond the region. This statement is an indicative of the fact that Russia's support has limits and cannot be as great as it was in the Cold War because of the devastating effects of the nuclear weapons. Therefore, Russia's first aim was to ease the crisis.

In this period, Russia generally supported the idea of preserving the LOC, as did the US. As Malek pointed out most Russian security experts were in favor of declaring the LOC as a formal international border. ${ }^{436}$ Putin attempted to surmount the crisis. In Almaty, President Putin met with the presidents of India and Pakistan, Atal Bihari Vajpayee and Pervez Musharraf, respectively to ease the crisis. ${ }^{437}$ Musharraf took this move more positively. Musharraf stated that:

"Russia, with its long relations with India and now improving relations with Pakistan is most well-placed to play a key role in the resolution of disputes and improving relations between India and Pakistan. ",438

On 12 June 2002, a statement released by the Russian Foreign Ministry welcomed positive statements from India and urged Pakistan to also take positive steps such as reducing transboundary terrorism and preventing the infiltration of militants through the LOC. ${ }^{439}$

\footnotetext{
${ }^{435}$ The Ministry of Foreign Affairs of the Russian Federation. 17 May 2002, Press Release, The Answer of the Official Spokesman of the Russian Federation Foreign Ministry Alexander Yakovenko to an ITAR-TASS Question in Connection with the Terrorist Act in the Indian State of Jammu and Kashmir [online] Available at: http://www.mid.ru/en/maps/in//asset_publisher/EpJ5G4lcymvb/content/id/557142 [Accessed 31.03.2017].

${ }^{436}$ Opinion of the Russian Pakistan specialist Vladimir Moskalenko (2002). "Eksperty 'NG': 'Esli Konflikt ne Pogasit, Destabilizatsiya Grozit Vsemu Regionu'" ('NG' experts: "If we do not succeed in resolving the conflict, the entire region could be destabilized."). Nezavisimaya Gazeta, 5 June 2002 in Martin Malek (2004). Russian Policy toward South Asia: An Update Asian Survey, Vol. 44, No.3, May/June 2004, University of California Press, p. 388.

${ }^{437}$ President of Russia. 4 June 2002, President Vladimir Putin met with Indian Prime Minister Atal Bihari Vajpayee [online] Available at: http://en.kremlin.ru/events/president/news/27123 [Accessed 23.03.2017] and President of Russia 4 June 2002 President Vladimir Putin met with Pakistan's President Pervez Musharraf [online] http://en.kremlin.ru/events/president/news/27120 [Accessed 23.03.2017].

${ }_{438}$ Gorshkov, N. (2003). Pakistan begins ' new chapter' with Russia, BBC News, World Edition. 6 February 2003, Thursday [online] Available at: http://news.bbc.co.uk/2/hi/south_asia/2734383.stm [Accessed 27.03.2017].
} 
Russia also contacted the US in order to help resolve the crisis. For example, the Russian Foreign Minister Igor Ivanov and the US Secretary of State Colin Powell met to discuss international and regional problems. Afterwards, the Russian Foreign Ministry made an announcement stating that both Russia and the US discussed the ways to reduce the tension between India and Pakistan as early as possible. ${ }^{40}$ They both prioritized mitigating the crisis and later reconsidering their differences.

Increasing Russian distrust of Pakistan concerning the terrorist groups can be seen in an interview with Deputy Foreign Minister Vyacheslav Trubnikov conducted by Vremya Novostei (Newstime). Trubnikov stated that it is largely believed in Russia that some Islamic fighters in Kashmir have been trained by the Taliban, which Pakistan and its Inter-Services Intelligence also supported. ${ }^{441}$

In another article written by the then Russian Foreign Minister Igor Ivanov, Russia articulated its understanding of Indian sensitivities and declared that India and Russia shared the same problems. Igor Ivanov wrote in his article that:

"Cross-border terrorism is an acute problem for many countries. An essential precondition for the effective struggle against this threat is the close cooperation of neighboring states. In particular, for the security of Russia a grave threat is posed by the presence of Chechen terrorists and foreign mercenaries in the Pankisi Gorge on the territory of Georgia. In this connection we give special emphasis to the speediest possible implementation of the agreements of the Russian and Georgian presidents on reinforcing security in the Russian-Georgian border area, reached in the course of their recent meeting in Chisinau at the CIS summit. For the same reasons Russia treats with understanding the concern of India over the penetration of groups of militants through the Line of Control into the state of Jammu and Kashmir. It shares the opinion about the need for the fulfillment by Pakistan of the obligations assumed to liquidate the terrorist infrastructure on the territory under its control. ${ }^{, 442}$

On 3 December 2002 came a statement from, Alexander Kadakin, the Russian Ambassador to India. In his statement, he condemned terrorism and named the groups in Kashmir

\footnotetext{
${ }^{439}$ The Ministry of Foreign Affairs of the Russian Federation. Press Release On Moves by Indian Leadership, Aimed at Reducing Tension in South Asia Region, 12 June 2002 [online] Available at: http://www.mid.ru/en/web/guest/maps/in//asset_publisher/EpJ5G4lcymvb/content/id/553876 [Accessed 31.03.2017].

${ }^{440}$ The Ministry of Foreign Affairs of the Russian Federation. Russian Minister of Foreign Affairs Igor Ivanov Meets with US Secretary of State Colin Powell, 13 June 2002 [online] Available at:

http://www.mid.ru/en/web/guest/foreign_policy/international_safety/crime/-

/asset_publisher/3F51ZsLVSx4R/content/id/553940 [Accessed 31.03.2017].

${ }^{441}$ Katerina Labetskaya, , Mentalitet 'Kholodnoy Voiny' Obyazan Umeret „, [The „, cold war „, mentality has to die], interview with Deputy Foreign Minister Vyacheslav Trubnikov, Vremya Novostei [Newstime] (Moscow). 11 September 2002, p. 4. Cited in Martin Malek (2004). Russian Policy toward South Asia: An Update Asian Survey, Vol. 44, No.3 May/June 2004, University of California Press, p. 389.

${ }^{442}$ The Ministry of Foreign Affairs of the Russian Federation. Article Written by Russian Minister of Foreign Affairs Igor Ivanov, „Russia and India: Together in the Struggle Against International Terrorism. The Strategic Partnership in Action. 2 December 2002 [online] Available at: http://www.mid.ru/en/web/guest/foreign_policy/international_safety/crime//asset_publisher/3F51ZsLVSx4R/content/id/537910 [Accessed 31.03.2017].
} 
as terrorist groups. He also urged Pakistan to fulfill its obligations regarding the terrorist networks in its country.

"Our countries share a common vision of the issue of preserving peace and stability in South Asia. The precrisis state of Indian-Pakistani relations this past summer showed only too clearly that terrorism could be detrimental to inter-state relations and global stability, if someone was tempted to portray international banditry as some kind of a "liberation struggle" or to use such banditry for attaining foreign policy goals. Precisely this threat emanates from extremist groups, which are entrenched on Pakistani-controlled territories. We hope that Pakistan will fully and unconditionally fulfill its commitments, thereby thwarting trans-border terrorism and destroying the terrorist infrastructure on its own territory. ",443

The above statements released by Russian politicians and experts reveal Russia's support for India during the 2001-2 crisis. India was very satisfied with this level of Russian confidence. The Indian Prime Minister at that time, Atal Vajpayee, even hoped that Russia would play an active role in pressuring Pakistan to curb the activities of the terrorist groups within Pakistan. ${ }^{444}$ However, this level of support was still very low in comparison to the Soviet Union's support of India during the crises before 1980s. Russia's support on 2001 crisis was consistent with the US and China. It blamed Pakistan, and did not use blaming language against the US and China.

Here, one should note that Russia was also suffering from Islamic terrorist groups and had the same interest as India in preventing these groups. It was therefore expected that Russia should have more aggressively supported India, instead of just giving rhetorical support. Russia instead chose to act in accord with the US. It was because an overt Russian support for India would have threatened Pakistan. This would have put the US in a difficult position because then it would have to be more supportive of Pakistan as an ally in a global war against terrorism. In other words, a firm Russian stance with India would have compelled the US to firmly stand with Pakistan. It would have therefore weakened the efficiency of US mediation efforts to deescalate this conflict with a nuclear dimension. Russia did not follow this path and collaborated with the US. This collaborative Russian mediation could possibly be attributed to the Russian support of the US campaign against global terror in general, especially at the initial stages of the campaign. However, the US campaign brought the US near regions where Russia traditionally viewed as its own sphere of influence. It was clear that Russia would not have contented with increasing US influence in both Central Asia and South Asia in the long term. Therefore, Russia could have used the India-Pakistan crisis in 2001

\footnotetext{
${ }^{443}$ This statement from Ambassador Kadakin is taken from Embassy of India Moscow Ambassador Kadakin's article in the Nezavisimaya Gazeta. Strategic Partnership is an Optimal Model of Russian-Indian Interaction, 03.12.2002 [online] Available at: http://www.indianembassy.ru/index.php/111-media/visit-archives/475-03122002-ambassador-kadakinsarticle-in-the-nezavisimaya-gazeta- [Accessed 22.03.2017].

${ }^{444}$ Kulikov, V. (2002). Atal Vadhzpai: ' My s Putinym Obsudim Vse Klyuchevye Voprosy',, [Atal Vajpayee: We have discussed all key issues with Putin], Izvestia , 3 December 2002, p. 4 cited in Martin Malek (2004). Russian Policy toward South Asia: An Update Asian Survey, Vol. 44, No.3 May/June 2004, University of California Press, p. 389.
} 
as an opportunity to show its influence in the region. This in turn would have deteriorated the crisis between India and Pakistan. Because of the nuclear dimension, Russia chose not to compete with US and weaken US mediation of the 2001 India - Pakistan crisis.

An evaluation of Russian mediation during the post-Cold War era, however, requires considering the changing foreign policy of Russia throughout the 1990s. During the first years of the Yeltsin ${ }^{445}$ presidency, Russian foreign policy was enthusiastic about the West. For example, in his address to the United Nations Security Council on 31 January 1992, Yeltsin stated that:

"I think the time has come to consider creating a global defence system for the world community. It could be based on a reorientation of the United States Strategic Defense Initiative, to make use of high technologies developed in Russia's defense complex. We are ready to participate actively in building and putting in place a pan-European collective security system...Russia regarded the United States and the West not as mere partners but rather as allies...",446

Rising inflation, job insecurity, and poverty, however, caused an immense socioeconomic crisis in Russia and soon led to disenchantment by the majority of the Russian population with Russia's reformist course and with the West in general. ${ }^{447}$ Disappointment with the West gradually contributed to Russia's foreign policy change from favoring full integration with western institutions to a more assertive one. ${ }^{448}$ The early signs of this change in foreign policy had already manifested itself by 1993. For example, in February 1993, Yeltsin referred to Russia's special rights in the regions of the former Soviet Union. Yeltsin pointed out that international organizations, including the UN, should have given Russia special powers to assure peace and stability in the former Soviet Union because the cessation of armed conflicts in former Soviet regions was also crucial for Russian interests. ${ }^{449}$ Moreover, Russia argued that it was responsible for protecting ethnic Russians living abroad in the former Soviet Union. This claim gave Russia a valuable foreign policy instrument with which it could assert its strategic objectives. ${ }^{450}$

\footnotetext{
${ }^{445}$ Boris Yeltsin was the first President of the Russian Federation. He served from 1991 to 1999.

${ }^{446}$ UN Document S/PV, 3046, The Address of the President and Chairman of the Government of the Russian Federation Boris Yeltsin to the United Nations, 31 January 1992, p. 44 [online] Available at: http://www.un.org/en/ga/search/view_doc.asp?symbol=S/PV.\%203046 [Accessed 23.01.2018].

${ }^{447}$ Adomeit, H. (1995). Russia as 'Great Power' in World Affairs: Images and Reality, International Affairs (Royal Institute of International Affairs 1944-), Vol. 71, No. 1 (January 1995), Wiley on behalf of the Royal Institute of International Affairs, p. 58.

${ }^{448}$ Adomeit, H. (1995). Russia as 'Great Power' in World Affairs, International Affairs, Vol. 71, No. 1, Wiley on behalf of the Royal Institute of International Affairs, p. 58.

${ }^{449}$ ITAR-TASS, In a speech to a congress of the Civic Union, a center-right alliance, in late February 1993, 1 March 1993 cited in Adomeit, H. (1995). Russia as 'Great Power' in World Affairs, International Affairs, Vol. 71, No. 1 (January 1995), Wiley on behalf of the Royal Institute of International Affairs, pp. 46-47.

${ }^{450}$ Izvestia (1994). Moskva razrabotala programmu za zashchity 30 millionov russkikh v blizhnem zarubezh'e,', 17 February 1994, cited in Adomeit, H. (1995). Russia as 'Great Power' in World Affairs, International Affairs, Vol. 71, No. 1 (January 1995), Wiley on behalf of the Royal Institute of International Affairs, pp. 47-48.
} 
In November 1993, the changing Russian attitude against the West had become more evident through a study conducted by the Russian Foreign Intelligence Service, which described NATO as the "biggest military grouping in the world that possesses an enormous offensive potential." This report also blamed NATO for being laden with stereotypes of bloc thinking. ${ }^{451}$

In the second half of the 1990s, socioeconomic problems heightened. As a result, Yeltsin fired the foreign minister Andrei Kozyrev, who was one of the predominant architectures of proWestern foreign policy after the collapse of the Soviet Union. Yevgeny Primakov, more a hardliner than Kozyrev, became foreign minister in $1996 .{ }^{452}$ After the financial crisis in 1998, Primakov became the Prime Minister. He held the position until Vladimir Putin took power. These changes demonstrated the transition of Russian policy from a pro-western stance to a more hardline position. All of these developments culminated in the release of a new national security concept on 10 January 2000. This new report highly criticized the structure of international relations based on the domination exerted by certain developed Western states. The US was blamed for acting unilaterally and for using military force without applying the fundamentals of international law. This national security concept emphasized that Russia's interests required "strengthening its positions as a great power and as one of the influential centers of a multipolar world." ${ }^{453}$

This new concept first found its practical application in Russia's relations with its traditional partners. During his visit in India on 3 October 2000, for example, Russian president Putin talked about the need to create a democratic world order and discussed the need to reform the UN. ${ }^{454}$

One can briefly argue that, starting in the early 1990s and through the end of 1990s, Russian foreign policy moved from being enthusiastic with Western principles to a search for finding a new role for Russia in global politics. This changing foreign policy throughout the 1990s is important for my argument because one may attribute the reason for Russian apathy to the 1990 Kashmir crisis to shrinking Soviet power and the approaching end of the Cold War. This, however, does not explain Russian collaboration with the US in the Kargil crisis in 1999 and in the 2001-2002 military standoff, although Russian foreign policy had already become more assertive. This strengthens my

\footnotetext{
${ }^{451}$ Izvestia (1993). Perspektivy rasshireniia NATO i interesy Rossii. Doklad sluzhby vneshnei razvedki', 26 November I993, cited in Adomeit, H. (1995). Russia as 'Great Power' in World Affairs, International Affairs, Vol. 71, No. 1 (January 1995), Wiley on behalf of the Royal Institute of International Affairs, p. 49.

${ }^{452}$ Freedman, R. O. (2001). Russian Policy toward the Middle East: The Yeltsin Legacy and the Putin Challenge, Middle East Journal, Vol. 55, No. 1, (Winter, 2001), p. 60.

${ }^{453}$ Ministry of Foreign Affairs of the Russian Federation Official Website. Foreign Policy Fundamental Documents National Security Concept of the Russian Federation 10 January 2000, Approved by Presidential Decree No. 24. [online] Available at:

http://www.mid.ru/en/foreign_policy/official_documents/-/asset_publisher/CptICkB6BZ29/content/id/589768 [Accessed 23.01.2018].

${ }^{454}$ President of Russia. President Vladimir Putin's News Conference with Indian Prime Minister Atal Bihari Vajpayee Summarizing Russian-Indian Negotiations, 3 October 2000, [online] http://en.kremlin.ru/events/president/transcripts/21593 [Accessed 23.01.2018].
} 
argument that it was the nuclear dimension which compelled the US and Russia to collaborate in the crises between India and Pakistan.

\subsubsection{Chinese Mediation of the Crisis}

China was more actively engaged in this crisis than the crises of 1990 and 1999. On 31 July 2002, the Chinese Foreign Minister Tang Jiaxuan met with his Indian counterpart Yashwant Sing at the ASEAN (Association of Southeast Asian Nations) Regional Forum. In this meeting, Tang Jiaxuan highlighted the positive steps taken by Pakistan and its role in the campaign against terrorism. Tang Jiaxuan said that:

"China, which has kept a close eye on the situation in South Asia, has no selfish interests in the IndiaPakistan dispute. China's policy on the issue is to make peace and facilitate talks... We note that Pakistan voiced objection to acts of terror in all forms and manifestations. The Pakistani government's stance on fighting terrorism is explicit and firm. We hope that India and Pakistan will ease tensions and make peace between them through dialogue, which is in the interest of both countries and is also a desire of the international community. ",455

One can interpret the above statement as a small amount of support for Pakistan. However, China was still not in the position to support Pakistan to a larger degree as it had during the Cold War era. Tang also demonstrated China's willingness to cooperate with other actors in easing the crisis between India and Pakistan. He said to US Secretary of State Colin Powell over the phone that:

"China is very concerned about the development of the India-Pakistan situation, and will spare no effort to promote reconciliation, so that the tension between India and Pakistan can be eased. ",456

The Chinese President Jiang Zemin also met with his counterpart Pervez Musharraf. He told him that:

“China hopes that Pakistan and India will settle their dispute peacefully through dialogue. China supports all efforts to alleviate the tension between Pakistan and India and to safeguard peace and stability in south Asia.",457

From these statements made by Chinese officials, one can detect a tone that China was not as passive as it was in the 1990 and 1999 crises. In the 2001 crisis, China not only advocated for India and Pakistan to solve their problems with each other, but also actively engaged in easing the crisis through meetings with Indian and Pakistani officials and politicians. This Chinese engagement was not in competition with the US, but was more collaborative. Even if China stated its support on Pakistani position in some occasions (such as in ASEAN conference), it also

\footnotetext{
455 Xinhua News Agency. (2002). China Urges India-Pakistan talks on border tensions. 31 July 2002, NEXIS.

${ }^{456}$ People's Daily. (2002). US FMs Discuss India-Pak Situation by Phone. 28 May 2002. [online] Available at: http://en.people.cn/200205/28/eng20020528_96586.shtml [Accessed 26.03.2017].

457 Xinhua News Agency (2002). Jiang Hopes For Peaceful Settlement of India - Pakistan Dispute, Xinhua General News Service 2 August 2002, NEXIS.
} 
highlighted that only a direct dialogue can solve the crisis between India and Pakistan. China was therefore not overtly pro-Pakistani as in the crisis before 1980s.

Both the 1999 Kargil crisis and the 2001 crisis demonstrated that non-state actors and terrorist groups add an additional complexity to the deterrence mechanism between states. The attacks initiated by non-state actors led to frequent crises between nuclear states, posing extra challenges to the stability reached at the nuclear level. The 1999 Kargil crisis occurred because of the trespassing of the non-state actors in the LOC, and the 2001 crisis occurred because of the terrorist attacks on Indian Parliament. In the 2001 crisis when the conflict started to subside, the Kaluchak terrorist attack increased tensions again, and caused India to consider enlarging the scope of the offensive, which could have escalated to a nuclear level without international mediation. Increasing the number of crises initiated by terrorist attacks in our contemporary world requires thinking in terms of the relationship between international mediation and nuclear deterrence. International mediation plays an important role in reducing the conflict dynamic between nuclear dyads, preventing overreaction by facilitating communication. It can therefore hinder a crisis from escalating to a nuclear level.

V.P. Malik, Indian Army Chief during the 2002 conflict, also underlined the escalation risk inherent in the India-Pakistan crisis. V.P. Malik stated in an interview by Chindu Sreedharan and Josy Joseph that there is a threshold between India and Pakistan, which makes conventional war possible, despite the nuclear capabilities by both states. ${ }^{458}$

Another important phenomenon in terms of the nexus between international mediation and nuclear deterrence is the friction between civil and military leaders and how they perceive threat and success. It is also visible in the India-Pakistan conflict. The analysis of the 2001-2002 crisis revealed that the views of civilian leaders and military concerning the success of India was highly differentiated. Civilian leaders commented that India was successful, whereas the military leaders were dissatisfied with the results. Indian national security expert K. Subrahmanyam argued that:

"If deployment of troops on the border was meant to serve as an exercise in coercive diplomacy and to compel the US to apply pressure on Pakistan to promise a visible and permanent end to cross-border terrorism, then it would be fair to say that the purpose has been achieved. ",459

In contrast, retired Indian Major General Afsir Karim stated that

\footnotetext{
${ }^{458}$ The Rediff (2001). Interview with General V. Prakash Malik, Part III 'Kargil was a Good Wake Up Call. 28 July 2001, done by Chindu Sreedharan and Josy Joseph [online] Available at: http://www.rediff.com/news/2001/jul/28inter.htm [Accessed 22.03.2017].

459 The Times of India (2002). Premature Pullback vs Army Fatigue. 26 October 2002 [online] Available at: http://timesofindia.indiatimes.com/edit-page/TIMES-SAMVADBRPremature-Pullback-vs-Army-

Fatigue/articleshow/26300607.cms [Accessed 21.03.2017].
} 
"The deployment of our armed forces in battle stations for over 10 months, with a view to coercing Pakistan into stopping cross-border terrorism, has failed to achieve its stated purpose... "460

The dissatisfaction articulated by Indian military leaders also showed that nuclear stability could be fragile without international mediation. For example, retired Brigade General Vijai K. Nair said:

“...The fact that you deployed the entire military and did not take punitive action against terrorists demonstrated to all that New Delhi does not have the political will to use the means it has deliberately created to secure India when the chips are down." 461

Retired Lieutenant General V.K. Sood and Pravin Sawhney, predominant author in defense issues, also argued in their book that:

"Facing tremendous pressure, the Indian leadership lacked the stomach to take a war inside Pakistan."

Discussion of this friction between military and civilian leaders is important because it indicates that in the absence of international mediation, unsatisfied military leaders could have easily taken steps deteriorating the crisis.

The problem of studies analyzing the crises between India and Pakistan was that they only focused on direct deterrence. They mainly neglected the mediation of other actors as a complementary factor in easing the crisis. On the other hand, studies that have incorporated mediation in analysis have only focused on the US. The fragile escalation dynamic in South Asia, however, requires an analysis of the interaction of US mediation with other major powers in the region. The cases showed that the collaborative behavior of Russia and China with the US helped the US to mediate successfully. If, for example, the alignment requests of Pakistani Prime Minister Shariff were not rejected by both Russia and China in the 1999 Kargil war, US mediation efforts might have lost its effectiveness. We can of course never definitely measure the impact of the fear of isolation, as we cannot travel back in time to analyze the incidents in a world where Russia and China did not support US mediation. We can interpret this only by comparing the 1999 and 2001 cases with the 1965 and 1971 cases. In the 1965 and 71 crises, the different alignment options of Pakistan, between the US and China, allowed Pakistan to prolong the conflict and reduce the effectiveness of US mediation. The behavior of other major powers, whether competitive or collaborative, is therefore an important factor in increasing or decreasing the escalation dynamic of conflict between India and Pakistan.

\footnotetext{
${ }^{460}$ Ibid.

${ }^{461}$ Sudarshan, V. (2002). Mirage 2001-02. Outlook, 04 November 2002 [online] Available at: http://www.outlookindia.com/magazine/story/mirage-2001-02/217748 [Accessed 28.03.2017].

${ }^{462}$ Sood, V.K. and Sawhney, P. (2003). Operation Parakram: The War Unfinished, p. 83.
} 
Pivotal deterrence that only analyzes the mediation of the US, which neglects the interaction of Russia and China with US mediation does not explain the dynamics of mediation that deescalated the 2001 crisis. This sub-case also demonstrated that the mediation was based on Russia and China's loosely agreed understanding of the US mediation, which reflects the collaborative mediation. It was not a highly institutionalized cooperation based on legally binding rules as collective actor deterrence theory asserts.

\subsubsection{Mumbai Terrorists Attacks in November 2008}

\subsubsection{Overview}

Mumbai attacks were a series of coordinated attacks organized by the terrorist organization Lashkar-e-Taiba from 26 to 29 November $2008^{463}$. On 26 November 2008, a group of ten well-organized men targeted renowned touristic places in Mumbai.

The first attack took place at the restaurant, Cafe Leopold. The attackers opened fire on the restaurant and then joined the attack taking place at the Taj Mahal Hotel, which started around 9.20 PM on Wednesday 26 November. Cafe Leopold is popular with foreign tourists and close to the Taj Mahal Palace hotel. The Taj Mahal Palace hotel is a popular tourist hotel where some international politicians, bankers, and bureaucrats also stay. Around the same time, other group of attackers stormed the Oberoi - Trident Hotel, which is located in the main business district. It is a popular place among business travelers. Meanwhile, two gunmen armed with heavy weapons stormed into the crowded Chhatrapati Shivaji Terminus station (formerly Victoria Terminus). Afterwards, attackers went to the Cama \& Albless Hospital and opened fire inside and outside the hospital. Other gunmen took control of the Nariman House business and residential complex. The complex was housing the Jewish Lubavitch outreach center. After the gunfight, six people were dead including a rabbi and his wife. ${ }^{464}$ There were also two separate explosions, one in the Mazagaon $^{465}$ and one in a taxi. ${ }^{466}$ They was also gunfight in the Metro Cinema. ${ }^{467}$ The gunfight

\footnotetext{
${ }^{463}$ Norman, T.L. (2009). Risk Analysis and Security Countermeasure Selection. Boca Raton: CRC Press Taylor \& Francis Group, p. V.

${ }^{464}$ BBC News (2009). The timeline of 2008 Mumbai attacks were taken from. Mumbai attacks: Key Sites 26 November 2009 [online] Available at: http://news.bbc.co.uk/2/hi/south_asia/7751876.stm [Accessed 28.03.2017] and BBC News (2008). Timeline: Mumbai Under Attack 1 December 2008 [online] Available at: http://news.bbc.co.uk/2/hi/south_asia/7754438.stm [Accessed 28.03.2017].

${ }_{465}$ Mazagaon is one of the seven islands in Mumbai.

466 Nair, D., Desai, S. et al. (2008). Tracing the Terror. The Indian Express, 10 December 2008, pp. 1-4 [online] Available at: http://archive.indianexpress.com/news/tracing-the-terror-route/396335/1 [Accessed 19.08.2016].

${ }^{467}$ CNN Library (2015). Mumbai Terror Attacks Fast Facts, 4 November 2015 [online] Available at: http://edition.cnn.com/2013/09/18/world/asia/mumbai-terror-attacks/ [Accessed 28.03.2017].
} 
continued for three days and the crisis was over on Saturday morning on 29 December 2008. By the end of the crisis, 166 people were dead. ${ }^{468}$

The magnitude of the attack dramatically increased the tension between India and Pakistan. India blamed the Inter-Services-Intelligence, the Pakistani intelligence agency, in designing the attack. ${ }^{469}$ Pakistan, however, denied the allegations. Wajid Shamsul Hasan, Pakistan's High Commissioner to Britain, declared that Pakistan was not involved in the planning of Mumbai attacks. ${ }^{470}$ India was not convinced, and the tension further increased. There were also some military deployments. In late December, the New York Times reported that Pakistan had relocated some of its troops from Afghanistan border in the west to the Indian border in the east. ${ }^{471}$ Based on the statements of two intelligence officers, Dawn reported that some 20,000 Pakistani soldiers were on the move to the Indian border. Moreover, both India and Pakistan cancelled leave for military personnel. ${ }^{472}$ Despite the disconcerting developments, a positive development also occurred. The Indian High Commissioner to Pakistan, Satyabrata Pal, met with Pakistani Foreign Secretary Salman Bashir in Islamabad. The Indian side assured that India was not deploying military units along the border, and India had no plans for military action. ${ }^{473}$ These developments slightly helped reduce the tension between India and Pakistan. On 5 January 2009, another level of cooperation occurred. India had issued a file, which explains the links between elements in Pakistan and the Mumbai attacks. ${ }^{474}$ Indian Minister of External Affairs Shri Pranab Mukherjee also stated that India insisted on the extradition of the Mumbai perpetrators to India, who were behind the Mumbai attacks. However, he added that if it was not possible for some reason, the attackers could also have been tried in Pakistan. However, Mukherjee stated that his comments should not have been understood as India forgave its demands for extradition of those, who were responsible for Mumbai

\footnotetext{
${ }^{468}$ Lakshmi, R. (2012). India Hangs Lone Surviving Terrorist from 2008 Mumbai Attacks. The Washington Post, 21 November 2012 [online] Available at: https://www.washingtonpost.com/world/asia_pacific/india-hangs-lone-survivingterrorist-from-2008-mumbai-attacks/2012/11/21/ad02d6fe-3412-11e2-bfd5-e202b6d7b501_story.html [Accessed 28.03.2017].

${ }^{469}$ Freeze, C. (2011). Accused in India massacre claims ties to Pakistani secret service. The Globe and Mail, 11 April 2011 [online] Available at: http:/www.theglobeandmail.com/news/world/americas/accused-in-india-massacre-claimsties-to-pakistani-secret-service/article1981052/ [Accessed 28.03.2017].

${ }^{470}$ The Independent (2009). Diplomat Denies Pakistan Role in Mumbai Attacks. 31 January 2009 [online] Available at: http:/www.independent.co.uk/news/world/asia/diplomat-denies-pakistan-role-in-mumbai-attacks-1521700.html [Accessed 28.03.2017].

${ }^{471}$ Oppel, R.A.Jr., and Masood, S. (2008). Pakistan Moves Troops Amid Tension With India. The New York Times, 26 December 2008 [online] Available at: http://www.nytimes.com/2008/12/27/world/asia/27pstan.html [Accessed 13.03.2017].

${ }^{472}$ Dawn (2008). Pakistan Cancels Army Leave, Shifts Troops. 26 December 2008 [online] Available at: https://www.dawn.com/news/956284 [Accessed 28.03.2017].

${ }^{473}$ Express India (2008). India not Building up Troops, as Pak toes anti-war line. 27 December 2008 [online] Available at: http://archive.indianexpress.com/news/india-not-building-up-troops-as-pak-toes-antiwar-line/403618/ [Accessed 28.03.2017].

${ }_{474}$ Rabasa, A, and Blackwill, R.D. et.al. (2009). The Lessons of Mumbai. Occasional Paper, RAND Cooperation, p. 12 [online] Available at: https://www.rand.org/pubs/occasional_papers/OP249.html [Accessed 22.09.2017].
} 
attacks. ${ }^{475}$ Pakistan also positively responded to the Indian initiatives. Pakistani Advisor to the Prime Minister for Interior Rehman Malik stated that Pakistan had arrested 124 individuals, who were believed to be connected with Lashkar-e-Taiba. Malik also added that the trials would be transparent and highlighted the need for cooperation between Pakistani and Indian investigators. ${ }^{476}$ These mutual gestures helped prevent high tension and immediate crisis. However, a certain level of tension continued. Even in the February 2009 session held in Lok Sabha, for example, Indian Minister of External Affairs Mukherjee stated that:

"Firstly, that the terrorist attack on Mumbai again underlines the grave threat that terrorism poses to peace and stability and therefore has to be seen in the context of the global challenge of terrorism. Terrorism emanating from Pakistan is of course a direct threat to India, but it is equally a regional and a global threat. Secondly, from our investigations the evidence was conclusive that the attack was planned, executed and launched from Pakistan territory, by Pakistanis and by elements based in Pakistan. "477

Through these statements, Mukherjee not only blamed Pakistan for the Mumbai attacks, but also indicated that the threats coming from Pakistan posed a danger to the entire world. India's Prime Minister Manmohan Singh also addressed both Houses of Parliament, and in his speech, he also highlighted how the danger coming from Pakistan threatens the entire world.

"There is greater appreciation in the international community of the threat that exists to the region and the world from the terrorism emanating from Pakistan. "478

The 2008 Mumbai attacks did not target the decision-makers of India as it did in the 2001 Indian Parliament Attack; however, it targeted highly touristic places in the city of Mumbai. This received international attention. Below is the reaction of major powers to the crisis.

\subsubsection{US Mediation of the 2008 Mumbai Crisis}

The US stayed neutral to the 2008 Mumbai crisis. The US President George W. Bush called both Indian Prime Minister Manmohan Singh and Pakistani President Asif Ali Zardari, and urged both countries to cooperate with each other in the investigation. ${ }^{479}$ Bush told Singh that American agencies would support India's investigation into the Mumbai terror attacks and take on a "shared commitment" to combat terrorism. Bush added that the US would work together with the international

\footnotetext{
${ }^{475}$ Varadarajan, S. and Dikshit, S. (2009). No Dilution of Position, says Pranab. The Hindu, 17 January 2009 [online] Available at: http://www.thehindu.com/todays-paper/No-dilution-of-position-says-Pranab/article16352902.ece [Accessed 14.03.2017].

${ }^{476}$ Masood, S. (2009). Pakistan Says 124 Arrested in Mumbai Investigation. New York Times, 15 January 2009 [online] Available at: http://www.nytimes.com/2009/01/16/world/asia/16pstan.html [Accessed 14.03.2017].

${ }^{477}$ Lok Sabha Debate (2009). The Minister of External Affairs made a statement regarding 'Follow-Up to Mumbai Terrorist Attack.' LT 10458-A/09 [online] Available at: https://indiankanoon.org/doc/339019/ [Accessed 28.03.2017].

${ }^{478}$ Rajya Sabha (2009). President's Address to both the Houses of Parliament assembled together on the 12th February 2009 [online] Available at: http://rajyasabha.nic.in/rsnew/session_journals/215/12022009.pdf [Accessed 02.03.2015].

${ }^{479}$ The American Presidency Project. Press Briefing by Deputy Press Secretary Gordon Johndroe, 31 December 2008 [online] Available at: http://www.presidency.ucsb.edu/ws/index.php?pid=85279 [Accessed 28.03.2017].
} 
community to go after extremists. ${ }^{480}$ Additionally, the US sent a special investigation team of the Federal Bureau of Investigation (FBI) to Mumbai to help with the investigations. ${ }^{481}$

The most notable US mediation came when US President George W. Bush sent the US Secretary of State Condoleezza Rice to the region. On 3 December 2008, Rice first stopped by in India to meet Indian Prime Minister Manmohan Singh. She stated that Pakistan had a responsibility to cooperate with India and help prevent attacks. In the meantime, Rice warned India that impulsive moves could bring unintended consequences. ${ }^{482}$

On 4 December 2008, Rice visited Pakistan as well, and met with Pakistani President Asif Ali Zardari, Prime Minister Yousuf Raza Gilani, Foreign Minister Shah Mehmood Qureshi and army chief General Ashfaq Parvez Kayani. Rice said that there was irrefutable evidence that some groups within Pakistan were involved in the Mumbai attacks. She warned that Pakistan would need to bring the perpetrators to justice, otherwise the US would act. ${ }^{483}$

The US mediation of 2008 attacks was not comprehensive. The US condemned the attack, urged India and Pakistan to work together, but refrained from blaming Pakistan.

\subsubsection{Russian Mediation of the 2008 Mumbai Crisis}

The first reaction to the Mumbai attacks came from the Russian President Dimitry Medvedev. He condemned the attacks and supported the actions of India to suppress terrorist acts. ${ }^{484}$ After tensions had increased, Russia clearly articulated its concerns about the nuclear component of the crisis. On the official webpage of the Russian Foreign Ministry, it was stated that:

"Moscow has received with extreme concern news of a massive buildup of troops and military equipment on both sides of the India-Pakistan border. The tension in this region has reached a dangerous level. There are worrying reports that New Delhi and Islamabad are not ruling out the use of military force against each other. The Russian Federation resolutely urges India and Pakistan to exercise maximum restraint and not allow the situation on the border to develop into a military-based scenario... Whereas any confrontation between New Delhi and Islamabad would only

\footnotetext{
${ }^{480}$ The Times of India (2008). US Support Mumbai attack investigation: Bush tells PM, 1 December 2008 [online] Available at: http://timesofindia.indiatimes.com/world/us/US-to-support-Mumbai-attack-investigation-Bush-tells-PM/articleshow/3777459.cms?referral=PM [Accessed 28.03.2017].

${ }^{481}$ FBI (2009). Testimony Donald Van Duyn Chief Intelligence Officer Federal Bureau of Investigation Statement Before the Senate Committee on Homeland Security and Governmental Affairs Washington, DC., 8 January 2009 [online] Available at: https://archives.fbi.gov/archives/news/testimony/fbi-role-in-mumbai-investigation [Accessed 28.03.2017].

${ }^{482}$ Wax, E. and Lakshmi, R. (2008). As Rice Presses Pakistan, Mumbai Residents Hold Massive Rally. Washington Post Foreign Service, Thursday, 4 December 2008 [online] Available at: http://www.washingtonpost.com/wpdyn/content/article/2008/12/02/AR2008120200884.html?sid=ST2008120203535 [Accessed 13.03.2017].

${ }^{483}$ The Times of India Press Trust of India (PTI). Mumbai Attack: Rice asks Pak to act urgently, else US will act. 6 December 2008 [online] Available at: http://timesofindia.indiatimes.com/world/pakistan/Mumbai-attack-Rice-asks-Pakto-act-urgently-else-US-will-act/articleshow/3801376.cms? [Accessed 21.03.2017].

${ }^{484}$ The Ministry of Foreign Affairs of the Russian Federation. Press Release On the Terrorist Acts in Mumbai. 27 November 2008 [online] Available at: http://www.mid.ru/en/web/guest/maps/in/-/asset_publisher/EpJ5G4lcymvb/content/id/315104 [Accessed 31.03.2017].
} 
benefit their common enemy, international terrorism, whose aim is to pit India and Pakistan against each other and thus destabilize the situation in South Asia. That prospect looks especially threatening as these states possess nuclear weapons de facto. We hope that the governments of India and Pakistan, aware of their high responsibility for the maintenance of peace and security in the region, will do everything in their power to defuse current tension in their bilateral relations by politico-diplomatic means. To this end the Russian Federation stands ready to provide all necessary assistance to New Delhi and Islamabad. "485

In this statement above, Russia's concern of the nuclear component of the crisis can be easily detected. It was also announced that Russia was ready to give assistance to both actors of the conflict in order to ease the crisis.

\subsubsection{The Chinese Mediation of 2008 Mumbai Crisis}

Chinese engagement in this crisis followed the same pattern as in the 2001-02 crisis. High-level officials communicated with their Indian and Pakistani counterparts. They urged them to stay calm. For example, the Chinese foreign minister Yang Jiechi called the Indian and Pakistani foreign ministers, Pranab Mukherjee and Shah Mahmood Qureshi, respectively. He told them that problematic issues between the two countries could only be resolved through dialogue. He urged both foreign ministers to improve their relations. He also said that improved relations between India and Pakistan are in the interests of the entire world. More importantly, Yang Jiechi declared his country's readiness to collaborate with India, Pakistan and with the rest of the world to cope with the terrorism. ${ }^{486}$

Another statement came from the Chinese Foreign Ministry spokesperson Liu Jianchao. He stated that:

"China firmly opposed terrorism. It accorded with the fundamental interest of India and Pakistan to strengthen dialogue and bilateral cooperation. It is also in line with the requirements for regional peace and stability and the common expectation of the international community. ${ }^{4887}$

Furthermore, China also sent a delegation to the crisis region. It was headed by the then Deputy Foreign Minister He Yafei. Their mission was to transmit the message to the Indian and Pakistani leadership that China was interested in only a peaceful conduct of relationships in South Asia. $^{488}$

\footnotetext{
485 The Ministry of Foreign Affairs of the Russian Federation. Statement of the Russian Ministry of Foreign Affairs. 27 December 2008 [online] Available at: http://www.mid.ru/en/web/guest/maps/pk/-/asset_publisher/GSALcG2HPipT/content/id/311206 [Accessed 28.03.2017].

${ }^{486}$ People `s Daily Online (2008). Chinese FM talks with Indian, Pakistani Counterparts over Phone. 27 December 2008 [online] Available at: http://en.people.cn/90001/90776/90883/6562940.html [Accessed 28.03.2017].

487 China Daily (Xinhua) (2008). China Calls for India-Pakistan Dialogue after Mumbai Attack. 4 December 2008 [online] Available at: http://www.chinadaily.com.cn/china/2008-12/04/content_7272727.htm [Accessed 28.03.2017].

${ }^{488}$ Siddiqi, R.A. (2014). China's Evolving Posture in South Asia: Some Reflections, IPRI Journal XIV, no. 2, Summer
} 
Here, it is evident that China was not as passive as it had been during the 1990 and 1999 crisis. Since the 2001 crisis, it has become more active, but has not pursued competitive policies as it did during the Cold War.

Briefly one can say that the international response to the 2008 Mumbai attacks was not strong, compared with the other incidents between India and Pakistan. It may be because although both India and Pakistan deployed its military units near the border, the threat of a major war was not high. For example, India's Defense Minister A.K. Antony stated that:

"We are not planning any military action. At the same time, unless Pakistan take actions against those terrorists who are operating in their soil against India, and also against all those who are behind this Mumbai terrorist attack, things will not be normal. ,489

The conflict had a low beginning point, leaving enough room for escalation. These features of the conflict might not have caused a major international concern. If the war had continued, mediation might have become necessary. It is, however, under these conditions, not possible to analyze whether the pattern of international mediation in the 2008 crisis fits to Expectations that I laid down. The only inference one can make is that Russia, China and the US did not blame each other for the conflict, and they did not use defamatory language against each other. They also did not support one particular side of the conflict. They also refrained from blaming one party of the conflict. However, I refrain from interpreting these attitudes as fitting to Expectation 4 and Expectation 5 because there is no evidence to suggest an explicit intention of mediation existed on the part of any of the major powers. This could also be observed by the following border skirmishes, which occurred in 2011, 2013, and 2016. These did not have the magnitude of those in the 1990, 1999, and 2001 crises and did not trigger international attention. It also did not cause large military deployments in the LOC, which in turn had an impact on the formation of international mediation, apart from being characterized by whether mediation was competitive or collaborative.

Another issue was that during the 2008 crisis, both Indian and Pakistani politicians did not issue threats of mass destruction. These changed attitudes of Indian and Pakistani politicians combined with the limitation of military moves might have had helped induced an environment where international mediation did not need to strongly emerged. This underscores the fact that in my study I argue that international mediation played a complementary role. My intention is never to argue that international mediation exclusively halted the crises between India and Pakistan. My thesis rather proposes and seeks to establish that, apart from the direct deterrence between parties of the

2014, p. 10 [online] Available at: http:/www.ipripak.org/wp-content/uploads/2014/10/1-article-s14.pdf [Accessed 28.03.2017].

${ }^{489}$ Voice of America (VOA). India Plans No Military Action Against Pakistan Over Mumbai Attacks. 27 October 2009 [online] Available at: http://www.voanews.com/a/a-13-2008-12-18-voa39-66737352/561773.html [Accessed 21.03.2017]. 
conflict, international mediation is an important complementary factor easing crises with nuclear dimension. The role of international mediation becomes particularly crucial, if the crisis started on a high level of escalation.

\subsection{Complementary / Discussion Cases}

\subsubsection{The Crises between India and China}

In this section, I analyze the crises between India and China as a complementary case to my main case. One can divide the India-Chinese relations into four phases. The first phase can be described as limited relations and limited conflict in the 1950s. The second phase started in 1960s and witnessed conflicts with high intensity, with which the 1962 Sino-Indian War reached its climax. The third phase is the skirmishes in the 1980s, and the deployment of military units to the Line of Actual Control. ${ }^{490}$ The fourth level began in the 1990s without serious conflicts, and only some verbal exchanges from high-level politicians.

To provide greater detail, in the first phase, India - China relations started with the China's declaration of Tibet as its internal region. A treaty signed by Tibet and the United Kingdom in 1914 demarcated the border between India and China in the Himalayan region, which is referred to as the McMahon Line. China declared that the agreement was invalid because Tibet had no authority to sign a treaty with Britain. ${ }^{491}$ With Tibet becoming a part of China, the McMahon Line between India and China became unclear, causing tensions between India and China. The relationship between India and China deteriorated when India gave asylum to Dalai Lama and his followers, who wanted to settle in India's Northeast region. ${ }^{492}$ Despite the tumultuous relationships, China and India did not escalate to war during the 1950s.

The second phase of the India - China relations had started in 1960s, with which the India China War of 1962 reached its lowest phase. India's implementation of the Forward Policy served as a major provocation to China in September 1962. Through Forward Policy, India sent troops into disputed places around the McMahon Line. The first major clashes occurred in Dhola post, established by Indians. The military clashes continued during September 1962, causing a fullfledged war between India and China on 20 October 1962. The US showed its support for India in

\footnotetext{
490 The Line of Actual Control is the territorial boundary between India and China. The part of the Line of Actual Control in the Eastern Sector (Himalayan region) is also called as McMahon Line.

491 Ministry of External Affairs Government of India. White Paper III, November 1959 - March 1960: Notes, Memoranda and Letters Exchanged and Agreements signed between the Governments of India and China, Sino-Indian Boundary Disputes No. 11, Note of the Chinese Government. 26 December 1959, in Claude Arpi Historical Documents White Papers on China [online] Available at: http://www.claudearpi.net/wp-content/uploads/2016/12/WhitePaper3NEW.pdf [Accessed 23.03.2017].

${ }^{492}$ New York Times International (1959). Dalai Lama Gets Asylum in India; Harried in Flight. Special to the New York Times. 4 April 1959 [online] Available at: https://partners.nytimes.com/library/world/asia/040459atibet-special.html [Accessed 21.03.2017].
} 
this conflict. In a communique issued on 21 October 1962, the US Department of State expressed that the US was "shocked at the violent and aggressive action of the Chinese communists against India". It furthered stated that "any Indian requests would be considered sympathetically." 493 The US also started to recognize the Indian position on the McMahon Line. On 27 October, Ambassador Galbraith stated that "the McMahon Line is an accepted international border and is sanctioned by modern usage. Accordingly, we regard it as the northern border of the North-East Frontier Agency $^{494}$ (NEFA) area." ${ }^{495}$ US President John F. Kennedy considered India a useful player in the region to win the political and economic race against China. M. Schlesinger recalls Kennedy's famous remark:

"We want India to win the race with China... If China succeeds and India fails, the economic development, balance of power will shift against us. ${ }^{496}$

The US offered its help to India. Kennedy sent a letter to Nehru stating that the US sympathy was with India and if India wants, the US could offer some practical assistance beyond sympathy. ${ }^{497}$ Subsequently, Nehru made a formal request for US military assistance. ${ }^{498}$ By 9 November 1962, the US had already air shipped about 3.5 million dollars worth of equipment and ammunition, adding up to 800 tons. ${ }^{499}$

The Indian position dramatically deteriorated in the battleground, and lost posts along the McMahon Line. These losses caused Nehru to send two letters to Kennedy. In the letters, Nehru requested greater US assistance, and protection by US jet fighters to protect Indian cities from air attacks by the Chinese. ${ }^{500}$ Discussions at the US Department of State reveals that the non-aligned

\footnotetext{
${ }^{493}$ New York Times, 22 October 1962 cited in Michael Brecher (1979-80). Non-Alignment Under Stress: The West and the India-China Border War Pacific Affairs, Vol. 52, No.4. (Winter, 1979-1980). Pacific Affairs, University of British Columbia, p. 613.

494 The North-East Frontier Agency was an administrative unit in India. In 1972, it became part of a Union Territory, and took name Arunachal Pradesh. In 1987, Arunachal Pradesh became an Indian state.

${ }^{495}$ J.K. Galbraith, n.11, p. 386, cited in Mishra, K. (2004). Rapprochement Across the Himalayas: Emerging Indo China Relations in Post-Cold War Period (1947 - 2003). India: Kalpaz Publications, p. 124.

${ }^{496}$ Schlesinger, A.M. Jr. (1965). A Thousand Days: John F. Kennedy in the White House. Boston and New York: Mariner Book Houghton Mifflin Company, p. 522.

${ }^{497}$ FRUS (1961-1963, Volume XIX, South Asia). Telegram From the Department of State to the Embassy in India. Washington, 28 October 1962 [online] Available at: https:/history.state.gov/historicaldocuments/frus1961-63v19/d187 [Accessed 28.03.2017].

${ }^{498}$ FRUS (1961-1963, Volume XIX, South Asia). Telegram From the Embassy in India to the Department of State. New Delhi, 29 October 1962 [online] Available at: https:/history.state.gov/historicaldocuments/frus1961-63v19/d188 [Accessed 27.03.2017].

499 FRUS (1961-1963, Volume XIX, South Asia). Memorandum From the President's Deputy Special Assistant for National Security Affairs (Kaysen) to President Kennedy. Washington, 9 November 1962. [online] Available at: https://history.state.gov/historicaldocuments/frus1961-63v19/d192 [Accessed 28.03.2017].

${ }^{500}$ The Indian Government has not declassified these letters. I took the information from FRUS, which also mentioned the summary made about these briefs in Biography of Nehru written by Sarvepalli Gopal (Gopal, Jawaharlal Nehru, Vol. 3, pp. 228-229) cited in FRUS (1961-1963, Volume XIX, South Asia). Telegram From the Embassy in India to the Department of State. New Delhi, 19 November 1962 [online] Available at:

https:/history.state.gov/historicaldocuments/frus1961-63v19/d203\#fn:1.3.2.2.282.4.5 [Accessed 28.03.2017].
} 
position of India made it problematic for the US to release the amount of assistance Nehru requested. ${ }^{501}$ In order to provide such assistance, the US needed guarantees that India would pursue more pro-West policies. On 21 November 1962, China declared a unilateral ceasefire, leaving no time for US negotiations with India to influence Indian foreign policy.

The US - India rapprochement during the 1962 war upset the Soviets. Khrushchev stated that China was responsible for the US - Indian rapprochement, and declared that Chinese withdrawal was a wise decision to prevent further US - India rapprochement. Khrushchev stated that:

"Some are already saying that China, if you please, ceased hostilities apparently because India began to receive support from the American and British imperialists, who are providing that country with arms. Consequently, say such people, the Chinese People's Republic felt that if the conflict were to develop further it might grow into a major war that would require even greater sacrifices. Yes, evidently the Chinese friends took account of the situation..., 502

This statement showed that the US overtly allied with India against China and supports Expectation 2 that mediator states align with one conflictive side against the other one. The Soviet Union had good relations with India, but they could not overtly align against a communist China. Almost one year after the conflict, however, the Soviet and Chinese discrepancies regarding the border conflict emerged. Pravda released articles criticizing the Chinese position in the 1962 conflict. These articles declared that the Chinese attitude toward India was not about ideology. It was nationalistic. Pravda also stated that China's position was to destroy India-Soviet relations. ${ }^{503}$

China rejected Soviet accusations, and blamed the Soviet Union that:

"The leadership of the C.P.S.U. (Communist Party of the Soviet Union) has become increasingly anxious to collude with the Indian reactionaries and has been bent on forming a reactionary alliance with Nehru against socialist China. The leadership of the C.P.S.U. and its press openly sided with Indian reaction, condemned China for its just stand on the Sino-Indian border conflict and defended the Nehru government. Two-thirds of Soviet economic aid to India have been given since the Indian reactionaries provoked the Sino-Indian border conflict. Even after large-scale armed conflict on the Sino-Indian border began in the autumn of 1962, the leadership of the C.P.S.U. has continued to extend military aid to the Indian reactionaries. "504

\footnotetext{
${ }^{501}$ FRUS (1961-1963, Volume XIX, South Asia). Telegram from the Department of State to the Embassy in India. Washington, 20 November 1962 [online] https://history.state.gov/historicaldocuments/frus1961-63v19/d206 [Accessed 25.03.2017].

${ }^{502}$ Pravda (1962). The Present International Situation and the Foreign Policy of the Soviet Union. Report to Session of the Supreme Soviet of the USSR. 12 December 1962, 13 December 1962, in The Current Digest of the Soviet Press, Vol. XIV, No. 52, 23 January 1963, p. 7 cited in Michael Brecher (1979-80). Non-Alignment Under Stress Pacific Affairs, Vol. 52, No. 4, Winter, 1979-1980, p. 619.

${ }^{503}$ Pravda (Moscow) 10 August 1963, cited in Mishra, K. (2004). Rapproachment Across the Himalayas: Emerging Indo - China Relations in Post Cold War Period (1947 - 2003). India: Kalpaz Publications, p. 122.

${ }^{504}$ Peking Review (1963). The Origin and Development of the Differences Between the Leadership of the C.P.S.U. and
} 
In the fall of 1967, the border between India and China in the Himalayan Kingdom of Sikkim, which was then an Indian protectorate, witnessed two military clashes: Nathu La Incident and Chola incident. On 11 September 1967, Chinese troops attacked Indian troops stationed across the Nathu La on the Sikkim border. On 15 September 1967 the hostilities stopped. On 1 October 1967, Chinese forces again infiltrated Sikkim, but this time to Cho La, in the north of Nathu La. ${ }^{505}$ On 10 October 1967, the Indian Army repelled them. The end of the battle saw the Chinese Army forced to leave Sikkim after being defeated by Indian troops. Sikkim became an Indian state in $1975 .{ }^{506}$

The relations between India and China positively started in the beginning of 1980s. In 1981, the Chinese Foreign Minister Huang Hua visited India, paving the way for vice-ministerial level talks between the two countries. The border issues were discussed in these formal talks, and eight rounds of talks were annually held from 1981 to $1987 .{ }^{507}$ Sumdorong Chu incident in 1986, however, overshadowed bilateral talks held in 1986. The Sumdorong Chu is a rivulet flowing from north-south in the Tawang District of Arunachal Pradesh, which is located on the eastern side of Bhutan. It is also known as Wandung. There were heavy clashes in this region during the India China war of $1962 .{ }^{508}$ In the summer of 1984, however, India erected an observation post on the bank of Sumdorong Chu in Arunachal Pradesh, where it sent its troops every summer, and withdrew every winter. When India returned to Sumdorong Cho in July 1986, it encountered Chinese intrusions in the area. Chinese troops had demolished the structures built by India in Sumdorong Cho, and built their own structures. ${ }^{509}$. This further increased the tension. In October 1986, the US Defense Secretary Caspar Weinberger visited China. Chinese leader Deng Xiaoping told Weinberger that if New Delhi continued nibbling across the border, China would have to "teach India a lesson" ${ }^{, 510}$ On October 1986, Indian Chief of Army Staff General Sundarji launched Operation Falcon as a response to China. In Operation Falcon, General Sundarji air-lifted an infantry brigade to Zimithang, a helipad near the Sumdorong Chu. ${ }^{511}$ These developments caused

Ourselves. Vol. 6, No. 37, 13 September 1963 [online] Available at: https://www.marxists.org/subject/china/pekingreview/1963/PR1963-37.pdf [Accessed 21.03.2017].

${ }_{505}$ Mishra, K. (2004). Rapproachment Across the Himalayas, p. 40.

${ }^{506}$ Elleman, B. et al. (2013). Conclusions. in Bruce A. Elleman, Stephan Kotkin, and Clive Schofield (edts.) (2013). Beijing's Power and China's Borders: Twenty Neighbors in Asia. New York and London: M.E.Sharpe, Inc., p. 317.

${ }^{507}$ Yang, Lu (2017). China - India Relations in the Contemporary World: Dynamics of National Interest and Identity. New York: Routledge, pp. 21-22. and Jetly, N. (1986). Sino-Indian relations: a quest for normalization. India Quarterly, Vol. 42, Issue. 1, January 1986, p. 57.

${ }^{508}$ Maxwell, Neville (1999). Sino-Indian Border Dispute Reconsidered. Economic and Political Weekly, Vol. 34, No. 15, 10-16 April 1999, p. 914.

${ }^{509}$ Ibid.

${ }^{510}$ Sutter, R.G. and Cronin, R.P. China-India Border Friction. CRS Report, 87-514F, Washington, DC., Congressional Research Service, Library of Congress. 19 June 1987 cited in Surjit Mansingh and Steven Levin (1989) "China and India: Moving beyond Confrontation” Problems of Communism Vol. 38, No.2-3. Mar-June 1989, pp. 41-42.

${ }^{511}$ Pandit, R. (2014). Govt yet to notify Operation Falcon on China border after 28 years. The Times of India, 4 Sep 2014 [online] Available at: http://timesofindia.indiatimes.com/india/Govt-yet-to-notify-Operation-Falcon-on-Chinaborder-after-28-years/articleshow/41652458.cms [Accessed 18.03.2017]. 
increasing predictions of war. ${ }^{512}$ In December 1986, India heightened tensions by declaring Arunachal Pradesh as a full-fledged state of the Indian Union. It was a risky move because some parts of Arunachal Pradesh was also claimed by China. ${ }^{513}$ In March 1987, the US Secretary of State George Schultz visited China and Deng Xiaoping repeated the message that Indian actions could carry grave consequences. China backed the seriousness of its threats with military action. China placed 20,000 troops from the $53^{\text {rd }}$ Army Corps in Chengdu and the $13^{\text {th }}$ Army in Lanzhou in the region by early 1987 along with heavy artillery and helicopters. ${ }^{514}$ As a counter move, the Indian Army started Operation Checker Board, under which India sent three divisions to positions around Wandung in Arunachal Pradesh and supplied 21,000 tons of equipment through airlifts. ${ }^{515}$ On June 1987, the crisis ceded by the visit of Indian External Affairs Minister N.D. Tiwari to China. ${ }^{516}$ In 1988, Rajiv Gandhi also visited China. During Rajiv Gandhi's visit, a joint group was established to discuss the border issues. The group was first composed of the Indian Foreign Secretary and the Chinese Vice-Foreign Minister. Later, senior representatives of the armies and ministries of defense also participated in the meetings. ${ }^{517}$

The most visible mediation on the part of external powers came from the US by means of the visits of US Secretary of Defense and US Secretary of State to the region. They brought a message sent by China to India. The Soviet Union played a limited role. As the Soviet - China relations were improving, the Soviet Union was caught in a dilemma. The crisis broke out just two weeks before the anniversary of the India - Soviet Union friendship agreement. It was therefore a test for Soviet-Indian relations. Despite this fact, in a state visit of Gorbachov to India, Gorbachov refrained from offering explicit Soviet support in a possible war with China. During the Press Conference, he refused to take sides. ${ }^{518}$

The relations between India and China have steadily improved during the 1990s. In September 1993, India and China signed the Agreement on the Maintenance of Peace and

\footnotetext{
512 Joshi, M. (1999). Warrior as Scholar. General Krishnaswami Sundarji passes away. India Today, Obituary, 22 February 1999 [online] Available at: https://www.indiatoday.in/magazine/obituary/story/19990222-generalkrishnaswami-sundarji-passes-away-780260-1999-02-22 [Accessed 16.02.2018].

${ }^{513}$ Hoffmann, S.A. (1990). India and the China Crisis. The US and the UK: University of California Press, p. 231.

${ }^{514}$ Chanda, N. (1987). Heading for a Conflict. Far Eastern Economic Review, 4 June 1987 cited in Surjit Mansingh and Steven Levin (1989). China and India: Moving beyond Confrontation. Problems of Communism, Vol. 38, No. 2-3, MarJune 1989, p.42.

${ }^{515}$ Bahdwar, I and Bobb, D. (1987). General K. Sundarji: Disputed Legacy. General Sundarji leaves behind a legacy most fiercely disputed in the history of the army. India Today, 15 May 1988 [online] Available at: http://indiatoday.intoday.in/story/generalsundarji-leaves-behind-a-legacy-most-fiercely-disputed-in-the-history-of-the-army/1/329290.html [Accessed 22.03.2017].

${ }^{516}$ Hindu, 17 June 1987 cited in Mishra, K. (2004). Rapprochement Across the Himalayas: Emerging Indo - China Relations in Post-Cold War Period (1947 - 2003). India: Kalpaz Publications, p. 64.

${ }^{517}$ Mansingh, S. (1994). India - China Relations in the Post-Cold War. Asian Survey, Vol. 34, No.3, March 1994, University of California Press, pp. 289-290.

${ }^{518}$ Foreign Broadcasting Information Service Daily Report Soviet Union (FBIS-DRSU). 2 December 1986, pp. D29. Cited in Keshav Mishra (2004). Rapprochement Across the Himalayas: Emerging Indo-China Relations in Post Cold War Period (1947-2003), p. 143.
} 
Tranquility, agreeing to reduce their military units along the Line of Actual Control. ${ }^{519}$ During the 2000s, only some low level tensions have been noted. In July 2006, the relations between India and China reached its peak when India and China reopened the Nathu La pass for trading, which connects the Indian state of Sikkim with China's Tibet Autonomous region. The Nathu La pass was closed after the 1962 India - China war. ${ }^{520}$ In April 2011, Indian Prime Minister Manmohan Singh and Chinese President Hu Jintao met in Sanja. They agreed to restore full defense co-operation by exchanging high-level military delegations. ${ }^{521}$ It was a major breakthrough which facilitated arrangements the high-level military issues. However, a certain level of friction also continued. For example, a low level military standoff took place in the western sector of the border between India and Pakistan. India claimed that Chinese soldiers intruded into India through the western rim of the Himalayas. However, the crisis did not escalate and both India and China restored the border that existed before 15 April 2013. ${ }^{522}$

As described above, the relations between India and China were highly conflictive during the 1960s. It witnessed one great war, and several skirmishes. The relationship between the US and the Soviet Union did not fulfill Expectation 1. They hardly competed with each other because the Soviet Union faced a dilemma. The competition between the Soviet Union and China increased at that time. However, the Soviet Union could not have overtly acted against a communist state. The Soviet Union also had good relations with India. In contrast, the US sided with India during the 1962 war. This suits the assumptions of Expectation 2 because in a nonnuclear platform, the mediator state does not hesitate to support one party of the conflict. The US supported India and protected India against a disproportional use of force by China. The reason could also partly be that a greater Chinese influence or communist influence would work against US interests in the region. The US therefore allied with India. One can see here that in a conflict where the parties of the conflict do not have nuclear weapons, the mediators could promote their own strategic interests. They had the luxury of pursuing policies, which maximize their own interest. Once the conflict gained a nuclear dimension, however, the US pursued a very limited approach and did not overtly support either side of the conflict. We see that in the crisis during the 1980s, especially in Operation

\footnotetext{
519 United Nations Peace Maker (1993). Agreement on the Maintenance of Peace and Tranquility along the Line of Actual Control in the India-China Border Areas. 7 September 1993 [online] Available at: http://peacemaker.un.org/chinaindia-borderagreement93 [Accessed 19.03.2017].

${ }^{520}$ BBC News (2006). Historic India - China link opens. 6 July 2006 [online] Available at: http://news.bbc.co.uk/2/hi/south_asia/5150682.stm [Accessed 19.03.2017].

${ }^{521}$ India Today (2011). India, China to restore defence cooperation. 13 April 2011 [online] Available at: $\mathrm{http}$ ://indiatoday.intoday.in/story/india-china-to-restore-defence-co-operation/1/135160.html [Accessed 29.03.2017]. 522 Reuters (2013). India says China agrees retreat to de facto border in faceoff deal. 6 May 2013, reported by Frank Jack Daniel, Michael Martina, Edited by Ron Popeski. [online] Available at: http://www.reuters.com/article/us-indiachina-idUSBRE9440B220130506 [Accessed 28.03.2017].
} 
Checkerboard, India tried to win US and Soviet support, but failed. ${ }^{523}$ This also fits the criteria of Expectation 4 and Expectation 5 in that during the conflicts which have a nuclear dimension, the mediators first try to end the crisis, and do not prioritize their own interests. They also reject the alignment demands of the parties of the conflict.

\subsubsection{The Relations between the US, Russia, and China in the Post-Cold War Era}

Relations between the US, Russia, and China present elements of collaboration and competition. This section seeks to demonstrate that in certain parts of the world, competition continues to characterize these relations in the post-Cold World Era. These examples are provided from the Kosovo war in 1999, the competition in Central Asia, the competing actions of the US and China in the South Asia Sea and competing trade agreements and projects attempted by the US and China in different parts of the world. The end of the Cold War had raised much hope, but it did not end the competition between major powers. The Kosovo war was the first crisis which tested the relations between the US, Russia, and China.

\subsubsection{The Competition in Balkans}

Under the Socialist Federal Republic of Yugoslavia (SFRY), Kosovo was granted autonomy in 1974. In 1989, the then head of the Serbian Communist party Slobodan Milosevic annulled the autonomy in Kosovo. ${ }^{524}$ After the dissolution of the SFRY in 1992, Kosovo stayed under the rule of Federal Republic of Yugoslavia (FRY), which then consisted of the Republics of Montenegro and Serbia. The level of violence in the conflict between ethnic Serbs and ethnic Albanians living in Kosovo gradually increased. In 1998, the situation deteriorated beyond repair with the intensification of clashes between the Kosovo Liberation Army (KLA) and Serbian security forces. This led to a Serbian offensive in the Kosovo region and ended with the dislocation of the Kosovo population. ${ }^{525}$ In March 1999, NATO launched an air campaign, justifying its actions as a humanitarian intervention. The problem with the NATO air campaign was that it was launched without a UN Security Council resolution, causing great resentment on the part of Russia.

Russia called the UN Security Council, and drafted a resolution with Belarus and India, calling for the cessation of use of force against FRY by NATO. Russia's representative said before voting that:

\footnotetext{
${ }^{523}$ Cohen, S.P. (1991). Superpower Cooperation in South Asia in Roger E. Kanet and Edward A. Kolodziej (eds.) The Cold War As Cooperation: Superpower Cooperation in Regional Conflict Management. London: MacMillan Academic and Professional Ltd., p. 287.

${ }^{524}$ BBC News (1999). History, bloody history BBC Online Network, 24 March 1999 [online] Available at: http://news.bbc.co.uk/2/hi/special_report/1998/kosovo/110492.stm [Accessed 23.03.2017].

${ }^{525}$ BBC News (2015). Kosovo Profile - Timeline: A chronology of events. 16 July 2015 [online] Available at: http://www.bbc.com/news/world-europe-18331273 [Accessed 24.03.2017].
} 
"Attempts to justify the military action under the pretext of preventing a humanitarian catastrophe bordered on blackmail, and those who would vote against the text would place themselves in a situation of lawlessness. Indeed, the aggressive military action unleashed by the North Atlantic Treaty Organization (NATO) against a sovereign State was a real threat to international peace and security, and grossly violated the key provisions of the United Nations Charter. "526

On 26 March 1999, the draft resolution was rejected. The NATO air campaign continued until Milosevic agreed to withdraw Serbian forces from Kosovo in June 1999. In February 2008, Kosovo declared independence. The US and European major powers recognized the independence of Kosovo, against the will of Serbia and Russia, causing great tensions between Russia and the US even to present day. ${ }^{527}$

One of the crucial incidents during NATO's air campaign was the bombing of China's embassy in Belgrade on 7 May 1999. After the bombing, the US immediately stated that the attack was unintended. US Secretary of Defense William S. Cohen and CIA Director George J. Tenet made a joint statement that:

“We deeply regret the loss of life and injuries from the bombing of the Chinese Embassy in Belgrade last night. The bombing was an error. Those involved in targeting mistakenly believed that the Federal Directorate of Supply and Procurement was at the location that was hit. That military supply facility was the intended target, certainly not the Chinese Embassy. "528

US President Bill Clinton also publicly apologized for the attack. ${ }^{529}$

While the US admitted and explained the attack as an accident, the Chinese reaction remained harsh. The Chinese Representative to the UN Security Council Qin Huasun stated that:

"The North Atlantic Treaty Organization (NATO), led by the United States, flagrantly attacked the Embassy of China with three missiles from different angles and caused serious damage. Two people had died, two were missing and many were injured. Flagrant bombing by NATO, led by the United States, had already caused enormous casualties and now it had gone so far as to bomb the Chinese Embassy. That was a violation of the sovereignty of China, and of the basic norms of international relations. China expressed the utmost indignation and severe condemnation of this barbaric activity. It made the strongest protest. NATO, headed by the Unite States, must assume the responsibility. China reserved the right to take further measures... The indiscriminate attack constituted a serious breach of

\footnotetext{
${ }^{526}$ The UN Security Council (1999). Security Council Rejects Demand for Cessation of Use of Force Against Federal Republic of Yugoslavia, Press Release SC/6659. 26 March 1999 [online] Available at: http://www.un.org/press/en/1999/19990326.sc6659.html [Accessed 28.03.2017].

${ }^{527}$ BBC News (2015). Kosovo Profile - Timeline: A chronology of events. 16 July 2015.

${ }^{528}$ Central Intelligence Agency (CIA) (1999). Joint Statement by Secretary Cohen and DCI Tenet News \& Information. 8 May 1999 [online] https://www.cia.gov/news-information/press-releases-statements/press-release-archive-1999/pr050899.html [Accessed 28.03.2017].

${ }^{529}$ CNN World (1999). Clinton apologizes to China over embassy bombing. 10 May 1999 [online] Available at: http://edition.cnn.com/WORLD/europe/9905/10/kosovo.china.02/ [Accessed 29.03.2017].
} 
international conventions. It was a crime of war and should be punished. ${ }^{, 530}$

An article released in The Guardian claims, based on three anonymous NATO officers, that the US bombing of the Chinese embassy was a deliberate act. The article claimed that the US realized that the Chinese embassy was helping the Yugoslavian army's communications by acting as a rebroadcast station. ${ }^{531}$ The Guardian article further claims, again based on senior anonymous military and intelligence sources in Europe and the US, that the Chinese embassy was "removed from a prohibited targets list after NATO electronic intelligence (Elint) detected it sending army signals to Milosevic's forces." 532

These developments prevented collaborative behavior between the US, Russia, and China, where the US ultimately acted unilaterally in the Kosovo crisis.

\subsubsection{The Competition in Central Asia}

Central Asia is another region of contention between the US, Russia and China. The competition in Central Asia has many dimensions. For example, the rivalry between the US and Russia in Central Asia began right after the end of the Cold War, where the US started to engage Central Asia in the 1990s. The main incentive was to integrate Central Asian states with western institutions and guarantee US access to energy resources in the region. ${ }^{533}$ The US intensified its activities in the region when the military operations started in Afghanistan in 2001. Colin Powell told the House International Relations Committee in February 2002 that the US "will have a continuing interest and presence in Central Asia of a kind that we could not have dreamed of before." 534 The US then acquired Karshi-Khanabad Air Base in Uzbekistan and Manas Air Base in Kyrgyzstan. ${ }^{535}$ This was the peak of US influence in the region.

Russia initially approved US presence in Central Asia under the framework of the global war against terrorism, and shared the same concern with the US regarding radical Islamic organizations in the region. However, Russia later became concerned that the US would stay in

\footnotetext{
${ }^{530}$ United Nations Security Council (1999) SC/6674/REV. 1. China, At Security Council Meeting, Registers Strongest Possible Protest Over Attack Against its Embassy in Belgrade. Press Release. 8 May 1999 [online] Available at: http://www.un.org/press/en/1999/19990508.SC6674.R1.html [Accessed 29.03.2017].

531 Sweeney, J., Holsoe, J. and Vulliamy, E. (1999). NATO bombed Chinese deliberately. The Guardian, Kosovo: Special Report, 17 October 1999 [online] Available at: https://www.theguardian.com/world/1999/oct/17/balkans [Accessed 29.03.2017].

532 Ibid.

${ }^{533}$ Wischnick, E. (2002). Growing U.S. Security Interests in Central Asia. Strategic Studies Institute Report, pg. 1 [online] Available at: http://www.strategicstudiesinstitute.army.mil/pubs/display.cfm?pubID=110 [Accessed 29.03.2017].

${ }_{534}$ Loeb, V. (2002). Footprints in Steppes of Central Asia. The Washington Post, 9 February 2002 [online] Available at: https://www.washingtonpost.com/archive/politics/2002/02/09/footprints-in-steppes-of-central-asia/93c3703c-9bf14137-967b-e51bf83e3e5a/ [Accessed 26.03.2017].

${ }^{535}$ Beehner, L. (2005). ASIA: U.S. Military Bases in Central Asia: Backgrounder. Council on Foreign Relations [online] Available at: http://www.cfr.org/russia-and-central-asia/asia-us-military-bases-central-asia/p8440\#p0 [Accessed 26.03.2017].
} 
Central Asia permanently. ${ }^{536}$ The authoritarian leaders of Central Asia also became increasingly suspicious about US intentions. They felt threatened, especially after the Color Revolutions in Georgia, Ukraine, and Kyrgyzstan. This diminished US influence in the region, and Uzbekistan urged the US to leave the military base in $2005 .{ }^{537}$ In 2013, the Kyrgyzstan Parliament gave a oneyear deadline to the US to leave the base. In 2014, the US vacated the military base. ${ }^{538}$

Recent trade agreements proposed by China also created a sphere of competition between major powers. China had initiated the project of the Silk Road Economic Belt and $21^{\text {st }}$ Century Maritime Silk Road, jointly named One Belt, One Road (OBOR). The Silk Road Economic Belt aims to connect the countries of the ancient Silk Road, to which China historically exported goods. It links China with the Persian Gulf and the Mediterranean Sea through Central Asia and the Indian Ocean. The $21^{\text {st }}$ Century Maritime Silk Road is designed to go from two routes. One is from China's coast to Europe through the South China Sea and the Indian Ocean. The other route is from China's coast through the South China Sea to the South Pacific. ${ }^{539}$ China's President Xi Jinping first announced the Silk Road Economic Belt initiative during a speech at Nazarbayev University in Kazakhstan. ${ }^{540} \mathrm{He}$ announced the $21^{\text {st }}$ Century Maritime in a speech to the Indonesian Parliament. ${ }^{541}$ An article in the Economist argues that these Chinese projects connect Asia and Europe, and contradict the following US trade agreements: Transatlantic Trade and Investment Partnership (TTIP) and Trans-Pacific Partnership (TPP). These US trade agreements respectively establish Europe and Asia as the main trading partners in trans-Atlantic and trans-Pacific trading blocs. The US therefore positions itself at the center of two trading blocs. In contrast, China considers Europe and Asia as one entity, positioning itself at the central point. ${ }^{542}$ Central Asia plays an important role in these Chinese projects as a transit region. Although US President Trump declared to withdraw from TTP, it is not known yet whether these Chinese projects will trigger US responses in the future.

\footnotetext{
${ }^{536}$ Stratfor (2016). Russia Re-Evaluates Security Ties in Central Asia. 3 March 2016 [online] Available at: https://www.stratfor.com/analysis/russia-re-evaluates-security-ties-central-asia [Accessed 26.03.2017].

${ }^{537}$ Wishnick, E. (2009). Russia, China, and The United States in Central Asia: Prospects for Great Power Competition and Cooperation in the Shadow of the Georgian Crisis. Strategic Studies Institute Report, pp. 2-3. [online] Available at: http://www.strategicstudiesinstitute.army.mil/pdffiles/PUB907.pdf [Accessed 26.03.2017].

538 Dzyubenko, O. (2014). U.S. vacates base in Central Asia as Russia's clout rises. Reuters, 3 Jun 2014 [online] Available at: http://www.reuters.com/article/us-kyrgyzstan-usa-manas-idUSKBN0EE1LH20140603 [Accessed 27.03.2017].

${ }^{539}$ Shaohui, T. (2015). Chronology of China's Belt and Road Initiative. Xinhuanet, 28 March 2015 [online] Available at: http://news.xinhuanet.com/english/2015-03/28/c_134105435.htm [Accessed 28.03.2017].

540 Jiao, W. and Yunbi, Z. (2013). Xi proposes a 'new Silk Road' with Central Asia. China Daily USA, 08 September 2013 [online] Available at: http://usa.chinadaily.com.cn/china/2013-09/08/content_16952304.htm [Accessed 27.03.2017].

${ }^{541}$ ASEAN - China Centre (2013). Speech by Chinese President Xi Jinping to Indonesian Parliament. 2 October 2013 [online] Available at: http://www.asean-china-center.org/english/2013-10/03/c_133062675.htm [Accessed 29.03.2017].

542 The Economist (2016). Our bulldozers, our rules: China's foreign policy could reshape a good part of the world economy. The Economist, 2 July 2016 [online] Available at: http://www.economist.com/news/china/21701505-chinasforeign-policy-could-reshape-good-part-world-economy-our-bulldozers-our-rules [Accessed 29.03.2017].
} 
The competition between Russia and China in Central Asia creates another dimension to the conflict. Russia and China actually collaborated in certain fields under the framework of the Shanghai Cooperation Organization. However, they viewed each other as competitors in Central Asia. Although Russia offered to combine the Chinese One Belt, One Road project with the Russian project of the Eurasian Economic Union ${ }^{543}$, it was not clear whether this would eliminate competition between the two powers. The Chinese project led to a closer relationship between China and Central Asia, this in turn, strengthened China's influence in the region. China was additionally interested in Central Asia because of its rich natural resources and proximity to China. This provided China with reliable energy resources, which it desperately needed. One can, however, describe Central Asia as a hinterland of Russia. The old pipeline networks built in the Soviet era gives Russia control over energy exports from Central Asia. Direct energy deals between Central Asia and China would jeopardize Russian dominance in the energy market, which is the backbone of the Russian economy. ${ }^{544}$

\subsubsection{The Competition in the South China Sea}

The South China Sea is another theater in which China and the US compete. One can divide the problems in the South China Sea into two main groups: Exploitation rights and navigation rights. The problem with exploitation rights involves the coastal states in the South China Sea: Brunei, Cambodia, China, Indonesia, Malaysia, Singapore, Taiwan, Thailand, the Philippines, and Vietnam. Article 57 of the UN Convention on the Law of the Sea (UNCLOS) states that:

"The exclusive economic zone shall not extend beyond 200 nautical miles from the baselines from which the breadth of the territorial sea is measured."

It gives coastal states the right to engage in economic activities within the range of 200 nautical miles, which is their Exclusive Economic Zone (EEZ). This causes a problem because the EEZs of the coastal states overlap in the South China Sea. ${ }^{546}$ Additionally, there are three groups of archipelago in the South China Sea, of which the ownerships are disputed. This causes additional problems in terms of maritime rights. The first group of the archipelago is Scarborough Shoal (Huangyan Dao in Chinese), and is claimed by both Philippines and China. The second group of islands is Paracel Islands (Xisha). They are claimed by China, Taiwan, and Vietnam. The third

\footnotetext{
543 Singh, A.I. (2015). Unequal Partners: China and Russia in Eurasia. The Diplomat, 03 June 2015 [online] Available at: http://thediplomat.com/2015/06/unequal-partners-china-and-russia-in-eurasia/ [Accessed 28.03.2017].

${ }^{544}$ Marantidou, V. and Cossa, R.A. (2014). The Great Game in Central Asia. Pacific Forum Center for Strategic \& International Studies (CSIS), PacNet, Number 73, 29 September 2014 [online] Available at: https://www.csis.org/analysis/pacnet-73-great-game-central-asia [Accessed 27.03.2017].

${ }^{545}$ United Nations Convention on the Law of the Sea, p. 44 [online] Available at: $\mathrm{http}$ //www.un.org/depts/los/convention_agreements/texts/unclos/unclos_e.pdf [Accessed 20.03.2017].

${ }^{546}$ Lowy Institute for International Policy. South China Sea: Conflicting Claims and Tensions [online] Available at: http://www.lowyinstitute.org/issues/south-china-sea [Accessed 29.03.2017].
} 
group of Islands is Spratly Islands (Nansha Qundao). China, Malaysia, Taiwan, the Philippines, Vietnam each claim some features over Spratly Islands. ${ }^{547}$

China claims that most of the archipelagos in the South China Sea are part of its territory. China also asserted this belief by sending two notifications to the UN Secretary General Ban KiMoon, the first one on 7 May $2009^{548}$ and the second one on 14 April 2011. In the second notification, China emphasized that:

"China has indisputable sovereignty over the islands in the South China Sea and the adjacent waters, and enjoys sovereign rights and jurisdiction over the relevant waters as well as the seabed and subsoil therefor. China's sovereignty and related rights and jurisdiction in the South China Sea are supported by abundant historical and legal evidence." 549

The Philippines challenged China's claim and brought the issue to Arbitral Tribunal on 22 January 2013. On 12 July 2016, Arbitral Tribunal decided in favor of the Philippines and concluded that there was no legal basis for China to claim historic rights on the South China Sea. ${ }^{550}$ China immediately called the decision of the tribunal void and not binding. On 13 July 2016, China's State Council Information Office (SCIO) held a press conference related to a white paper released by the Chinese government regarding the dispute between China and the Philippines. During the press conference, the spokesperson of the SCIO, Guo Weimin, expressed that the most important part of the white paper was that it emphasized Chinese sovereignty on Nanhai Zhudao (the islands in the South China Sea). He further explained that Nanhai Zhudao belongs to China and can be proven through historical records.

Weimin further said that:

“...the Chinese people have been conducting activities in the South China Sea for over 2,000 years. The Chinese people say that the South China Sea has been left to us by our ancestors. The arbitration case unilaterally initiated by the Philippines and the illegal arbitration by the ad hoc tribunal is a political farce carefully orchestrated under the legal pretext. The so-called award is illegal, null and void, and cannot change the fact that Nanhai Zhudao are China's inherent territory and can not deny China's territorial sovereignty and maritime rights and interests in the

\footnotetext{
${ }^{547}$ Ibid.

${ }^{548}$ Note Verbale CML/17/2009. from the Permanent Mission of the People's Republic of China to the UN SecretaryGeneral. New York, 7 May 2009 [online] Available at:

http://www.un.org/depts/los/clcs_new/submissions_files/mysvnm33_09/chn_2009re_mys_vnm_e.pdf [Accessed 24.03.2017].

${ }^{549}$ Note Verbale CML/8/2011. from the Permanent Mission of the People's Republic of China to the UN SecretaryGeneral. New York, 14 April 2011 [online] Available at:

http://www.un.org/depts/los/clcs_new/submissions_files/mysvnm33_09/chn_2011_re_phl_e.pdf [Accessed 24.03.2017].

${ }^{550}$ Permanent Court of Arbitration Press Release. The South China Sea Arbitration: (The Republic of the Philippines v. The People's Republic of China). 12 July 2016, pp. 1-2. [online] Available at: https://pca-cpa.org/wpcontent/uploads/sites/175/2016/07/PH-CN-20160712-Press-Release-No-11-English.pdf [Accessed 24/09/2016].
} 
South China Sea. This farce will not cause waves in the South China Sea, a sea that has been passed down to us by our ancestors. China's resolve and will to uphold our sovereignty and maritime rights and interests is as firm as ever." 551

Vice Foreign Minister Liu Zhemin also emphasized at the same conference that:

"Nanhai Zhudao are China's inherent territory. The activities of the Chinese people in the South China Sea date back to over 2,000 years ago. China is the first to have discovered and named, and explored and exploited Nanhai Zhudao and the South China Sea, and the first to have continuously, peacefully and effectively exercised sovereignty and jurisdiction over Nanhai Zhudao. China's sovereignty over Nanhai Zhudao and the relevant rights and interests in the South China Sea have been established in the long course of history. "„552

These statements demonstrate China's determination of not compromising its position regarding the South China Sea, which can also cause problems with the US in the region. Even before the Tribunal's decision was declared, China made its position clear. On 9 June 2016, the Chinese Ambassador to Britain Liu Xiaoming gave an interview to western journalists. ${ }^{553}$ Xiaoming blamed the US for China's problematical relationships with its neighbors, and stated that the US provoked them. Xiaoming stated :

"I think before America's so-called 'rebalancing in Asia Pacific', the South China Sea was very quiet, very peaceful. China was talking to the neighboring countries. We had a Declaration of Conduct. And the Philippines was talking to us. Once the Americans came in, so-called "rebalancing", things changed dramatically. The Vietnamese changed their position with regard to talking to China. The Philippines changed their position. I think the American move in the Asia Pacific emboldened those countries to change the traditional channel of negotiation with China. And they probably believe that they have the Americans behind them, and they can get a better deal with China. So I'm very suspicious of American motives. ",554

Ambassador Liu furthermore stated:

"Yet Americans now send more reconnaissance planes and warships. What they are doing is not for safeguarding free navigation. They are there to challenge China's sovereignty over the islands and reefs. And they make a dangerous provocation. China has a legitimate right to check what they are doing. The South China Sea is very wide. There is a lot of space and area for American warships and planes to go through. Yet they are not interested in the open sea. They are more interested in areas close to China's islands and reefs. What are their intentions? If they do not try to

\footnotetext{
551 Ministry of Foreign Affairs of the People's Republic of China. Vice Foreign Minister Liu Zhenmin at the Press Conference on the White Paper Titled China Adheres to the Position of Settling Through Negotiation the Relevant Disputes Between China and the Philippines in the South China Sea, 13 July 2016 [online] Available at: http://www.fmprc.gov.cn/mfa_eng/wjbxw/t1381980.shtml [Accessed 24/03/2017].

552 Ibid.

${ }^{553}$ The journalists participated to interview named by Ministry of Foreign Affairs of the People's Republic of China as Reuters' global news editor Alessandra Galloni, business and news investigation editor Simon Robinson, Breakingnews' editor John Foley, European Politics and Economic editor Mark John and Asia Top News editor Mike Collett-White.

${ }^{554}$ I used the transcript of the interview released on 07 July 2016 by Ministry of Foreign Affairs of the People's Republic of China Ambassador Liu Xiaoming gives interview to Reuters on the South China Sea [online] Available at: http://www.fmprc.gov.cn/mfa_eng/wjb_663304/zwjg_665342/zwbd_665378/t1378316.shtml [Accessed 23.03.2017]. Reuters published the interview on 3 July 2016 Torode, G. and Collett-White, M. (2016). Ahead of key court ruling, Beijing in propaganda overdrive Reuters 3 July 2016 [online] Available at: http://www.reuters.com/article/ussouthchinasea-ruling-idUSKCN0ZJ117 [Accessed 24.03.2017].
} 
provoke, I think the area and the region will be very peaceful, very stable. So there is no reason for foreign fleet to go to the South China Sea to patrol, to protect the free flights, the freedom of navigation." 555

These statements also allude to problems concerning navigation rights. China claims legal rights over the control of sea traffic passing through the islands in the South China Sea. The US, however, defends the right of freedom of navigation in international seas and claims that the area is open to international sea traffic. Because of this position, the US sent patrols near the artificial islands built by China in the South China Sea. ${ }^{556}$ According to an article released by the Wall Street Journal, some US officials said that several ally countries in the region approached the US and insisted that the US should stand against China's territorial claims in the region. If they did not, China may make additional territorial demands in the region. According to the same report, other US allies warned that greater US involvement in the region may have the opposite effect, and exacerbate the crisis. ${ }^{557}$

These developments show that although the US, China and Russia did not compete with each other in terms of strategy, concerning the India and Pakistan crises since the 1980s, they competed in other parts of the globe. The international structure changed at the end of the Cold War, but it did not end the struggles between the US, Russia, and China. It is especially important to note that although the relations between China and the US were strained after the Embassy attack in Belgrade, China did not change its policy against the US concerning the crisis between India and Pakistan in the 1999 Kargil crisis.

\footnotetext{
555 Ibid.

${ }^{556}$ Reuters (2015). U.S. Navy Destroyer nears islands built by China in South China Sea. 26 October 2015 [online] Available at: http://www.reuters.com/article/us-southchinasea-usa-idUSKCN0SK2AC20151026 [Accessed 29.03.2017].

${ }^{557}$ Entous, A., Lubold, G., and Barnes, J.E. (2015). US Military Proposes Challenge to China Sea Claims. The Wall Street Journal, 12 May 2015 [online] Available at: http://www.wsj.com/articles/u-s-military-proposes-challenge-tochina-sea-claims-1431463920 [Accessed 29.03.2017].
} 


\section{CONCLUSION}

In the conclusion part, I summarized the findings of the dissertation. I first compared the outcome of the nonnuclear and nuclear phases of the India - Pakistan crises, and discussed whether the results met my assumptions, which I laid out as Expectations. Second, I evaluated the results in the nuclear phase in order to expose whether one can observe the second part of my hypothesis.

The first finding is that international mediation was present in the conflict between India and Pakistan, even before the conflict gained a nuclear dimension. In the nonnuclear phase, however, international mediation was characterized by competition, in which the mediator states were prioritizing their own interests. The 1965 and 1971 wars met the Expectations mostly concerning the nonnuclear phase. The US, the Soviet Union, and China competed with each other as mediator states during this phase. The US was overtly proPakistan during the crises of 1965 and 1971. It prioritized its relationships with Pakistan and considered the impact of its actions on the ally structure. During the 1965 War, in particular, the divide between the Soviet Union and China resurfaced. China discredited the Tashkent Agreement sponsored by the Soviet Union, and claimed that the agreement was a collaboration between imperialists and social imperialists. In most of the statements, China used a defamatory language against the US and the Soviet Union in the nonnuclear phase. The Soviet Union was pro-Indian and completely antagonistic to the mediation efforts of the US and China. In other words, the mediator states supported one party of the conflict, even if it increased the tension between India and Pakistan and reduced the effectiveness of mediation. These attitudes of mediator states fulfill Expectation 1: competition and Expectation 2: mediator states support one party of the conflict.

In the nonnuclear phase, India and Pakistan sought maximum support from mediator states. When they were not supported, they threatened to change their foreign policy stance. This also fits Expectation 3: The sides of the conflict have more maneuver capability to choose different foreign policy (alignment) options. Ayub Khan's threats to approach China in the 1965 crisis and Zulfikar Ali Bhutto's complaints regarding the lack of US support are among the examples of maneuvering capability during the nonnuclear phase.

In the nonnuclear phase, the 1947 War is a subcase, which met least the Expectations. The US and the Soviet Union were struggling with the other problems after the Second World War. China was affected by civil war. The interests of the mediator states in 1947 war were 
therefore very low. At the end of the 1947 War, tension between India and Pakistan did not dissipate. Quite contrary, tensions gradually increased in the 1950s. A further analysis of the relations between the US, the Soviet Union, and China in the 1950s reflected the Expectations.

In the nuclear phase, which started with the nuclear tests of India in 1974, data illustrated that mediator states refrained from provoking the conflict. The Kahuta crisis in 1984 and the Brasstacks crisis in 1987 demonstrated that the US and the Soviet Union did not compete with each other in order to influence the conflict, although these two conflicts occurred during the Cold War. In the Brasstacks crisis, American and Soviet ambassadors even worked together to ease the crisis.

The pattern of collaboration between mediator states is most evident in the 1990 and 1999 Kargil crises. The US, the Soviet Union, and China did not blame each other for the initiation of the conflict during the 1990 crisis. China and the Soviet Union supported the Gates Mission initiated by the US. None of the mediator states aligned with one party of the conflict, making the mediation solid. Mediator states collaborated in the 1999 crisis as well. Neither China nor Russia attempted to discredit the US President Bill Clinton's mediation attempt. In the Kargil crisis, Pakistan tried to align itself with China and the US. These Pakistani attempts were rejected by both countries, making the international mediation effective. These actions of the mediator states in the 1990 Kashmir and the 1999 Kargil Crisis met Expectation 4: collaboration and Expectation 5: collaborative mediation places pressure on the sides of the conflict effective.

The comparison of the nuclear and nonnuclear phases revealed that once the India Pakistan conflict gained a nuclear dimension, the US, the Soviet Union/Russia, and China collaborated to ease the crises between the two countries. This finding supports the first part of the hypothesis, and answers my first and second research questions. Crises with nuclear dimension influence the relationships between major nuclear states and can cause changes in their mediation patterns.

The analysis of the crises in the nuclear phase demonstrated that collaboration between the US, Russia, and China reduced the alignment options for India and Pakistan. This was most obvious in the case of the 1990 Kashmir Crisis and the 1999 Kargil Crisis. In the 1999 Kargil Crises, Pakistani president Sharif's attempts to seek assistance from both China and the US failed. The US instead made Pakistan's withdrawal from the Line of Control as a 
prerequisite for US mediation. This attitude of mediator states put pressure on Sharif because of the lack of alignment options. Sharif also used US mediation and strong international collaboration as an excuse to back down from the conflict without losing face. Mediation was important for Sharif because his position was not strong vis-à-vis the military. The military could use an unsuccessful outcome as justification to topple him. ${ }^{558}$ The behavior of mediator states therefore played an additional role in reducing the tensions between India and Pakistan, apart from the deterrence they posed to each other. The analysis of the Kashmir Crisis in 1990 and the Kargil crisis in 1999 verified the second part of my hypothesis, and answered my third and fourth research questions. This change in behavior of mediator states created a second, complementary deterrence, apart from the direct deterrence between parties of the conflict, and helped reduced the conflict dynamic.

Russia, China, and the US collaborated with each other and did not blame each other for the conflict in both sub-cases of the 2001 Indian Parliament attack and 2008 Mumbai crisis. The extent of the 2001 and 2008 crisis, however, was not as large as the 1990 Kashmir and the 1999 Kargil Crises. The international attention was therefore not great concerning these crises.

The examination of the relations between the US, Russia, and China in the post-Cold War era revealed ongoing competition from all sides. The end of the Cold War did not automatically bring cooperation between them. The nuclear dimension of the crisis was therefore the critical factor in facilitating the collaboration between mediator states, not the end of the Cold War.

The analysis of the crises between India and China revealed almost the same pattern as the India - Pakistan dyadic conflicts. For example, the US overtly supported India in the SinoIndian War in 1962. The Soviet Union also supported India, though not overtly as the US, because China was a communist country. Nevertheless, the Soviet Union released articles in Pravda criticizing the Chinese position. After China acquired nuclear capabilities in 1964, the US and the Soviet Union did not support one party of the conflict in the 1967 crisis and in the crises of 1980s.

To conclude, I would like to emphasize that after analyzing the many crises one can still ask whether direct deterrence between India and Pakistan or the collaborative mediation

\footnotetext{
558 The General Musharraf anyways toppled Sharif only couple of months after the Kargil war in 12 October 1999.
} 
of major powers prevented the wars from escalating. It is hardly possible to concretely ascertain that collaborative mediation alone prevented wars. For this reason, I viewed collaborative mediation as a complementary measure to help direct deterrence, but not as a distinct factor. Therefore, I do not argue that collaborative mediation alone hindered the escalation. Here, one should remember Schelling's analogy about the curved slope. Schelling argued that direct deterrence is not a sharp cliff, but it is a curved slope. In this respect, even if one is confident that stability at the nuclear level is robust, increasing periods of the friction, high pressure, a shared territory that decreases the reaction time, all present in the Indo-Pakistani conflict, may cause adversaries to slip on the curved slope with each incremental step. This risk exists even if the adversaries do not intend to fall down. Collaborative mediation among major powers helps to set back these incremental steps because when major powers collaborate, they decline the aligning attempts of the parties of the conflict, thus strengthening the probability of mediation success. It also provides an opportunity to the parties of the conflict to retreat without losing face. These characteristics of collaborative mediation are stronger than the mediation of a single strong state, or the mediation of competing major powers. The ad hoc nature of collaborative mediation - one that is not highly institutionalized - also facilitates mediator states to easily participate in mediation efforts without having to make strong commitments, which is different from collective actor deterrence which requires strong commitments and consensus between members based on highly institutionalized arrangements.

As a final remark, this study contributes to the international relations discipline in identifying nuclear deterrence dynamics between new proliferator states and in comprehending the deterrence relationships between new proliferator states and established nuclear states. Most deterrence studies analyze the direct deterrence between the US and the Soviet Union during the Cold War, or the deterrence between the US, Russia, and China in the post-Cold War era. In other words, they analyze the nuclear deterrence between established nuclear states, which already have well-developed communication networks as well as standardized operational procedures in times of crisis. However, these conditions hardly exist in the context of relations between new proliferator states. The main challenges in the context of new proliferator states are the existence of opaque nuclear capabilities, asymmetric proliferation, and the ensuing danger of preemptive and preventive attack by one party of the conflict, which already possess nuclear capabilities. The unstable relations and limited communication between new proliferator states also aggravate these problems and make the situation more dangerous. Under these conditions, the findings of the dissertation 
are relevant and important in understanding the conflict dynamic and deterrence relations between new proliferator states, and the complementary role of collaborative mediation in preventing nuclear wars. 


\section{BIBLIOGRAPHY}

Adomeit, H. (1995). Russia as 'Great Power' in World Affairs: Images and Reality, International Affairs, Vol. 71, No. 1 (January 1995), Wiley on behalf of the Royal Institute of International Affairs, pp. 35-68.

Ahmad, A. (1987). India and Pakistan Signed an Agreement Today to Remove. United Press International, 2 March 1987 [online] Available at: http://www.upi.com/Archives/1987/03/02/India-and-Pakistan-signed-an-agreement-today-toremove/6640541659600/ [Accessed 27.03.2017].

Allison, G. (1969). Conceptual Models and the Cuban Missile Crisis. The American Political Science Review, Vol. 63, No. 3, September 1969.

Allison, G. (1971). Essence of Decision. Boston: Little, Brown and Company.

ASEAN - China Centre (2013). Speech by Chinese President Xi Jinping to Indonesian Parliament [online] Available at: http://www.asean-china-center.org/english/201310/03/c_133062675.htm [Accessed 29.03.2017].

Asghar, R. (1990). Bhutto Predicts Victory for Kashmir Independence Campaign, Reuters Library Report. 13 March 1990, cited in P.R. Chari et al. (2003). Perception, Politics and Security in South Asia: The compound crisis of 1990. London and New York: Routledge Curzon Taylor \& Francis Group, p. 222.

Asian Recorder (1955). Delhi, cited in Das Gupta, J.B. (1968) Jammu and Kashmir. The Hague: Martinus Nijhoff.

Association for Diplomatic Studies and Training India and Pakistan on the Brink: The 1998 Nuclear Tests Moments in the U.S. Diplomatic History [online] Available at: http://adst.org/2014/07/india-and-pakistan-on-the-brink-the-1998-nuclear-tests/ [Accessed 23.03.2017].

Bahdwar, I and Bobb, D. (1987). General K. Sundarji: Disputed Legacy. General Sundarji leaves behind a legacy most fiercely disputed in the history of the army. India Today, 15 May 1988 [online] Available at: http://indiatoday.intoday.in/story/general-sundarji-leavesbehind-a-legacy-most-fiercely-disputed-in-the-history-of-the-army/1/329290.html [Accessed 22.03.2017]. 
Baixas, L. (2008). Khan (1917/2002) General Tikka, Encyclopedia of Mass Violance [online] Available at: http://www.sciencespo.fr/mass-violence-war-massacreresistance/fr/node/2705 [27.03.2017].

Bajpai K.P. et al. (1997). Brasstacks and Beyond: Perception and Management of Crisis in South Asia. New Delhi: Ajay Kumar Jain Manohar Publishers \& Distributers.

Bajpai, R. (1987). Reuters Ltd. 2 March 1987 cited from Bajpai, K.P. et.al. (1997). Brasstacks and Beyond: Perception and Management of Crisis in South Asia. New Delhi: Ajay Kumar Jain Manohar Publishers \& Distributers, pp. 176-177.

Bajpai, R. (1987). Reuters Ltd. 3 March 1987 cited in Bajpai K.P. et al. (1997). Brasstacks and Beyond: Perception and Management of Crisis in South Asia. New Delhi: Ajay Kumar Jain Manohar Publishers \& Distributers, p. 178.

Barnetson, D. (1987). India forces on red alert at Pakistan border. United Press International, 23 January 1987 [online] Available at: http://www.upi.com/Archives/1987/01/23/India-forces-on-red-alert-at-Pakistanborder/1986538376400/ [Accessed 28.03.2017].

$B B C$ (1971). Pakistan intensifies air raids on India. [online] Available at: http://news.bbc.co.uk/onthisday/hi/dates/stories/december/3/newsid_2519000/2519133.stm [Accessed 27.03.2017].

BBC News (1999). History, bloody history BBC Online Network, 24 March 1999 [online] Available at: http://news.bbc.co.uk/2/hi/special_report/1998/kosovo/110492.stm [Accessed 23.03.2017].

BBC News (2002). Russia Backs India Over Kashmir, 7 February 2002 [online] Available at: http://news.bbc.co.uk/2/hi/south_asia/1807238.stm [Accessed 27.03.2017].

$B B C$ News (2003). India Warning over Nuclear War, 7 January 2003 [online] Available at: http://news.bbc.co.uk/2/hi/south_asia/2636157.stm [Accessed 28.03.2017].

$B B C$ News (2006). Historic India - China link opens, 6 July 2006 [online] Available at: http://news.bbc.co.uk/2/hi/south_asia/5150682.stm [Accessed 19.03.2017].

BBC News (2008). Timeline: Mumbai Under Attack, 1 December 2008 [online] Available at: http://news.bbc.co.uk/2/hi/south_asia/7754438.stm [Accessed 28.03.2017].

BBC News (2009). The timeline of 2008 Mumbai attacks were taken from. Mumbai attacks: Key Sites, 26 November 2009 [online] Available at: http://news.bbc.co.uk/2/hi/south_asia/7751876.stm [Accessed 28.03.2017].

BBC News (2015). Kosovo Profile - Timeline: A chronology of events, 16 July 2015 [online] Available at: http://www.bbc.com/news/world-europe-18331273 [Accessed 
24.03.2017].

BBC News (2015). Kosovo Profile - Timeline: A chronology of events, 16 July 2015.

BBC News: India - Pakistan Troubled Relations: Kashmir Insurgency [online] Available

at:

http://news.bbc.co.uk/hi/english/static/in_depth/south_asia/2002/india_pakistan/timeline/1989 .stm [Accessed 28.03.2017].

Beardsly, K. (2011). The Mediation Dilemma. The US: Cornell University Press.

Bearek, B. (2001). A Nation Challenged: Repercussions; 26 Die as Suicide Squad Bombs Kashmir Legislative Building. The New York Times, 2 October 2001 [online] Available at: http://www.nytimes.com/2001/10/02/world/nation-challenged-repercussion-26-die-suicidesquad-bombs-kashmir-legislative.html [Accessed 23.03.2017].

Beehner, L. (2005). ASIA: U.S. Military Bases in Central Asia: Backgrounder. Council on Foreign Relations [online] Available at: http://www.cfr.org/russia-and-central-asia/asia-usmilitary-bases-central-asia/p8440\#p0 [Accessed 26.03.2017].

Benjamin, M.R. (1982). India Said to Eye Raid on Pakistani A - Plants. The Washington Post, 20 December 1982 contributed by William Claiborne [online] Available at: https://www.washingtonpost.com/archive/politics/1982/12/20/india-said-to-eye-raid-onpakistani-a-plants/7e30dde5-e97c-45dc-82bb-521dee37a6ac/?utm_term=.1a9a5a59212e [Accessed 29.03.2017].

Bercovitch, J and Jackson, R. (2009). Conflict Resolution in the Twenty-first Century: Principles, Methods, and Approaches. Ann Arbor, the US: The University of Michigan Press.

Bercovitch, J. (2007). Mediation in International Conflicts: Theory, Practice and Developments in I. William Zartman (ed.) Peacemaking in International Conflict: Methods \& Techniques. Revised Edition. Washington, D.C.: United States Institute of Peace Press, pp. 163-195.

Bercovitch, J., Anagnoson, J.T., and Wille, D.L. (1991). Some Conceptual Issues and Empirical Trends in the Study of Successful Mediators in International Relations. Journal of Peace Research, Vol.28, No.1, Special Issue on International Mediation February 1991, pp. 717.

Bidwai, P. (2003). Nuclear South Asia: Still on the Edge. Frontline, Vol. 20 Issue 02, 18 January [online] Available at: http://www.frontline.in/static/html/fl2002/stories/20030131007211600.htm [Accessed 13.08.2016].

Bobb, D. and Badhwar, I. (1987) Game of Brinkmanship. India Today, 15 February 
1987 [online] Available at: https://www.indiatoday.in/magazine/cover-story/story/19870215game-of-brinkmanship-756869-1987-02-15 [Accessed 28.03.2017].

Bobb, D. and Badhwar, I. (1987). Back from the Edge. India, Pakistan hold marathon talks in New Delhi to defuse border crisis. India Today, 28 February 1987 [online] Available at: http:/indiatoday.intoday.in/story/india-pakistan-hold-marathon-talks-in-new-delhi-to-defuseborder-crisis/1/336739.html [Accessed 27.03.2017].

Boewe, C. (2006). Indian - Pakistani Wars in Thomas M. Leonard (ed.) Encyclopedia of the Developing World, Volume 1 A-E Index, New York and London: Routledge Taylor \& Francis Group, pp. 802-807.

Bokhari, F. and Luce, E. (2002). Bombers Kill 33 in Kashmir as US Envoy Visits India. Financial Times, 15 May 2002.

Bose, S. (2005). Anatomy of Violence: Analysis of Civil War in East Pakistan in 1971. Economic and Political Weekly, 8 October 2005, vol. 40, No. 41, pp. 4463-4471.

Brines, R. (1968). The Indo-Pakistani Conflict. London: Pall Mall Press Ltd.

Brodie, B. (1946). The Weapon: Implications for Military Policy in Bernard Brodie (ed.) The Absolute Weapon: Atomic Power and World Order. New York: Harcourt, Brace and Company, pp. 70-107.

Brookmire, D.A. and Sistrunk, F. (1980). The Effects of Perceived Ability and Impartiality of Mediators and Time Pressure on Negotiation. The Journal of Conflict Resolution, Vol. 24, No.2, June, 1980, pp. 311-327.

Bruce, R. (2009). American Diplomacy and the 1999 Kargil Summit at Blair House in Peter R. Lavoy (ed.) Asymetric Warfare in South Asia: The Causes and Consequences of the Kargil Conflict. New York: Cambridge University Press, pp. 130-143.

Burns, J.F. (1990). US Urges Pakistan to Settle Feud With India Over Kashmir. The New York Times, 21 May 1990 [online] Available at: http://www.nytimes.com/1990/05/21/world/us-urges-pakistan-to-settle-feud-with-india-overkashmir.html [Accessed 28.03.2017].

Burns, J.F. (2001). Pakistan Moves Against Groups Named by India. The New York Times, 29 December 2001 [online] Available at: http://www.nytimes.com/2001/12/29/world/pakistan-moves-against-groups-named-byindia.html [Accessed 23.03.2017].

Burns, J.F. and Dugger, C.W. (2001). India Builds Up Forces as Bush Urges Calm. The New York Times, 30 December 2001 [online] Available at: http:/www.nytimes.com/2001/12/30/world/india-builds-up-forces-as-bush-urges-calm.html 
[Accessed 23.03.2017].

C. Raja Mohan "Pak Must Pull Out Troops" Hindu, 28 June 1999, in Sumit Ganguly and S. Paul Kapur (eds.) (2009). Nuclear Proliferation in South Asia: Crisis behavior and the bomb. The USA and Canada: Routledge, p. 58.

Campbell, K.M., Einhorn, R.J., Reiss M.B. (2004). Tipping Point: Why States Reconsider Their Nuclear Choices. The US: Brookings Institution.

Central Intelligence Agency (CIA) (1999). Joint Statement by Secretary Cohen and DCI Tenet News \& Information, 8 May 1999 [online] https://www.cia.gov/newsinformation/press-releases-statements/press-release-archive-1999/pr050899.html [Accessed 28.03.2017].

Chakravorty, B.C. (1992). History of the Indo-Pak War 1965, ed. S.N. Prasad, History Division, Ministry of Defence, Government of India: New Delhi, p. 17. cited in McGarr, P.M. (2013). The Cold War in South Asia: Britain, the United States and the Indian Subcontinent 1945-1965. New York: Cambridge University Press, pp. 9-55.

Chanda, N. (1987). Heading for a Conflict. Far Eastern Economic Review, 4 June 1987 cited in Surjit Mansingh and Steven Levin (1989) China and India: Moving beyond Confrontation Problems of Communism Vol. 38, No.2-3. Mar-June 1989, pp. 30-50.

Chandrasekaran, R. and Lakshmi, R. (2001). New Delhi Lays Blame: India Implicates Militants in Attack But Struggles to Prove a Pakistani Role. Washington Post, 29 December 2001, A-1 cited in Nayak, P and Krepon, M. (2006). US Crisis Management In South Asia's Twin Peaks Crisis The Henry L. Stimson Center, Report 57 September 2006, p. 1-57 [online] Available at: https://www.stimson.org/sites/default/files/fileattachments/Twin_Peaks_Crisis.pdf [Accessed 22.03.2017].

Chari, P. R. et al. (2003). Perception, Politics, and Security in South Asia: The compound crisis of 1990. London and New York: RoutledgeCurzon, Taylor \& Francis Group.

Chari, P.R. (1995). Indo-Pak Nuclear Standoff: The Role of the United States. New Delhi: Ajay Kumar Jain Manohar Publishers \& Distributers.

Chari, P.R. (2003). Nuclear Crisis, Escalation Control, and Deterrence in South Asia. The Henry L. Stimson Center. Working Paper, Version 1.0 [online] Available at: https://www.stimson.org/sites/default/files/file-attachments/escalation_chari_1_1.pdf [Accessed 27.03.2017].

Chari, P.R. (et al.). (2007). Four Crises and a Peace Process: American Engagement in South Asia. Washington, DC.: The Brookings Institution Press. 
Chen, L.C. (2015). What Should be Knowing about the Kargil War. India Today, 26 July 2015 [online] Available at: http://indiatoday.intoday.in/story/kargil-war-vijay-diwasfacts/1/454125.html [Accessed 28.03.2017].

Chengappa, R. (1999). Dial-A-PM. India Today. 22 June 1999, NEXIS.

Chengappa, R. (2000). Weapons of Peace: the secret story of India's quest to be a nuclear power. New Delhi: Harper Collins Publishers.

Chengappa, R. (2002). Future Fire: The Shorter, Smarter Agni Heralds a New Genre of Missiles Directed Towards Pakistan. India Today, 11 February 2002 [online] Available at: http://indiatoday.intoday.in/story/shorter-smarter-agni-heralds-new-genre-of-missilesdirected-towards-pakistan/1/220437.html [Accessed 28.03.2017].

Chengappa, R. and Gupta, S. (2002). In Striking Distance. Vajpayee sounds war cry, India prepares for limited military offensive against Pakistan India Today, 3 June 2002 [online] Available at: http://indiatoday.intoday.in/story/vajpayee-sounds-war-cry-indiaprepares-for-limited-military-offensive-against-pakistan/1/221339.html [Accessed 24.03.2017].

Chicago Tribune Indian Forces Battle Moslems in Kashmir, 16 April 1990 cited in Chari, P. R. et al. (2003). Perception, Politics, and Security in South Asia: The compound crisis of 1990. London and New York: RoutledgeCurzon, Taylor \& Francis Group Chapter 4, p. 86.

China Daily (Xinhua) (2008). China Calls for India-Pakistan Dialogue after Mumbai Attack. 4 December 2008 [online] Available at: http://www.chinadaily.com.cn/china/200812/04/content_7272727.htm [Accessed 28.03.2017].

CIA Electronic Reading Room, Memorandum to Holders, Special National Intelligence Estimate, Prospects for Further Proliferation of Nuclear Weapons, SNIE 4-1-74, 18 December 1975, Secret Excised Copy. [online] Available at: http://www.foia.cia.gov/sites/default/files/document_conversions/89801/DOC_0001247369.p df [Accessed 27.03.2017].

Clancy, T., Zinni, T., and Koltz, T. (2004). Battle Ready. The US: G.P. Putnam's Sons, and Sidwick \& Jackson an imprint of a London: Pan Macmillan Ltd p. 347.

CNN Library (2015). Mumbai Terror Attacks Fast Facts, 4 November 2015 [online] Available at: http://edition.cnn.com/2013/09/18/world/asia/mumbai-terror-attacks/ [Accessed 28.03.2017].

CNN World (1999). Clinton apologizes to China over embassy bombing. 10 May 1999 [online] Available at: http://edition.cnn.com/WORLD/europe/9905/10/kosovo.china.02/ 
[Accessed 29.03.2017].

CNN World (1999). India Agrees to Kashmir Talks. 31 May 1999 [online] Available at: http://edition.cnn.com/WORLD/asiapcf/9905/31/india.pakistan.01/ [Accessed 28.03.2017].

Cohen, S. P. (1991). Superpower Cooperation in South Asia edited by Roger E. Kanet and Edward A. Kolodziej (eds.) (1991). The Cold War As Cooperation: Superpower Cooperation in Regional Conflict Management. London: Macmillian Academic and Professional Ltd, pp. 281-309.

Coll, S. (1990). Assault on Pakistan Gains Favor in India. Washington Post, 15 April 1990. [online] Available at: https://www.washingtonpost.com/archive/politics/1990/04/15/assault-on-pakistan-gainsfavor-in-india/0a3abaed-4dac-4bf2-9ade-e92ca2d62a26/ [Accessed 28.03.2017].

Coll, S. (2006). The Stand-Off: How jihadi groups helped provoke the twenty-first century's first nuclear crisis. The New Yorker, 13 February 2006 [online] Available at: http://www.newyorker.com/magazine/2006/02/13/the-stand-off [Accessed 29.03.2017].

Congressional Record - Extension of Remarks Think Tank Predicts Nuclear War Between India and Pakistan Dan Burton the US House of Representatives. 23 April 1998, p.E660. [online] Available at: http://www.gpo.gov/fdsys/pkg/CREC-1998-04-23/pdf/CREC1998-04-23-pt1-PgE660-4.pdf [Accessed 28.03.2017].

Congressional Record: After Kargil - What? Hon. Bill McCollum of Florida in the House of Representatives Thursday. 29 July 1999, E1694-E1695 [online] Available at: https://www.congress.gov/crec/1999/07/30/CREC-1999-07-30-pt1-PgE1694-3.pdf [Accessed 28.03.2017].

Council on Foreign Relations (2013). The Global Nuclear Nonproliferation Regime Issue Brief. 25 June 2013 [online] Available at: http://www.cfr.org/nonproliferation-armscontrol-and-disarmament/global-nuclear-nonproliferation-regime/p18984 [Accessed 28.03.2017].

Crawford, T.W. (2003). Pivotal Deterrence: Third Party Statecraft and the Pursuit of Peace. Cornell Studies in Security Affairs, the US: Cornell University Press.

CRO to British High Commissions, ' The Dispute Between India and Pakistan over the Rann of Kutch, 28 April 1965, PREM 13/391, TNA cited in McGarr, P.M. (2013). The Cold War in South Asia: Britain, the United States and the Indian Subcontinent 1945-1965, pp. 301-345.

Crocker, C., Hampson, F.O., and Aall, P. (1999). Introduction and Multiparty Mediation: Concepts, Issues, Strategies, and Actors: Introduction in Chester A. Crocker, Fen 
Osler Hampson, and Pamela Aall (eds.) Herding Cats: Multiparty Mediation in a Complex World. Washington, D.C.: United States Institute of Peace Press, pp. 3-47.

D‘ Costa, B. (2011). Nationbuilding, Gender and War Crimes in South Asia. New York and Canada: Routledge.

Dawn (1999). China Urges Negotiations. 11 June 1999, Karachi in Rashid Ahmed Siddiqi (2014). China`s Evolving Posture in South Asia: Some Reflections IPRI Journal (2014) Vol. XIV. No. 2 Summer 2014: 1-19, p. 6 [online] Available at: http://www.ipripak.org/wp-content/uploads/2014/10/1-article-s14.pdf [Accessed 29.03.2017].

Dawn (2008). Pakistan Cancels Army Leave, Shifts Troops. 26 December 2008 [online] Available at: https://www.dawn.com/news/956284 [Accessed 28.03.2017].

Dawn, 13 April 1971 Chou En-lai’s Message to Yahya Khan. 12 April 1971, comp. by Rajendra Kumar Jain (1981) China - South Asian Relations 1947-1980. Document 189, The Great Britain: The Harvester Press, John Spiers, p. 211.

Dawn, 4 November 1986 cited in Bajpai K.P. et al. (1997). Brasstacks and Beyond: Perception and Management of Crisis in South Asia. New Delhi: Ajay Kumar Jain Manohar Publishers \& Distributers, p. 159.

Deshmukh, B.G. (1994). The Inside Story. `The 1965 and 1971 wars were solely due to Pakistan's provocative action.' India Today, 28 February 1994 [online] Available at: http://indiatoday.intoday.in/story/the-1965-and-1971-wars-were-solely-due-to-pakistansprovocative-action/1/294879.html [Accessed 28/03/2017].

Dixit, A. (1990). India, Pakistan and the Great Powers in Jasjit Singh (ed.) (1990) India and Pakistan: Crisis of Relationship. New Delhi: Lancer Publishers Pvt. Ltd. in association with Institute for Defence Studies and Analysis, pp. 16-49.

Dixit, J. N. (1996). Anatomy of a Flawed Inheritance: Indo - Pak relations, 19701994. India: Konark Publishers.

Dixit, J.N. (2002). India - Pakistan in War \& Peace. Routledge, London and New York: Taylor \& Francis Group.

Dugger, C. (2001). India Weighs Using Troops to Hunt 2 Groups in Pakistan. New York Times, 23 December 2001 [online] Available at: http://www.nytimes.com/2001/12/23/world/india-weighs-using-troops-to-hunt-2-groups-inpakistan.html [Accessed 29.03.2017].

Dutt, V.P. (2001). Indo-Russian Relations: An Overview in V.D. Chopra (Edt.) IndoRussian Relations: Prospects, Problems and Russia Today. India: Kalpaz Publications, p. 33.

Dzyubenko, O. (2014). U.S. vacates base in Central Asia as Russia's clout rises. 
Reuters, 3 Jun 2014 [online] Available at: http://www.reuters.com/article/us-kyrgyzstan-usamanas-idUSKBN0EE1LH20140603 [Accessed 27.03.2017].

Elleman, B. (et al.) (2013). Conclusions. in Bruce A. Elleman, Stephan Kotkin, and Clive Schofield (edts.) (2013). Beijing's Power and China's Borders: Twenty Neighbors in Asia. New York and London: M.E. Sharpe, Inc., pp. 311-331.

Embassy of India Moscow Ambassador Kadakin's article in the Nezavisimaya Gazeta. Strategic Partnership is an Optimal Model of Russian-Indian Interaction, 03.12.2002 [online] Available at: http://www.indianembassy.ru/index.php/111-media/visit-archives/47503122002-ambassador-kadakins-article-in-the-nezavisimaya-gazeta- [Accessed 22.03.2017].

Enthoven, A.C. and Smith, K. W. (1971/2005). How Much Is Enough: Shaping the Defense Program 1961-1969 The US: RAND Cooperation, p. 174. [online] Available at: http://www.rand.org/content/dam/rand/pubs/commercial_books/2010/RAND_CB403.pdf [Accessed 27.03.2017].

Entous, A., Lubold, G., and Barnes, J.E. (2015). US Military Proposes Challenge to China Sea Claims. The Wall Street Journal, 12 May 2015 [online] Available at: http://www.wsj.com/articles/u-s-military-proposes-challenge-to-china-sea-claims1431463920 [Accessed 29.03.2017].

Express India (2008). India not Building up Troops, as Pak toes anti-war line. 27 December 2008 [online] Available at: http://archive.indianexpress.com/news/india-notbuilding-up-troops-as-pak-toes-antiwar-line/403618/ [Accessed 28.03.2017].

Far Eastern Economic Review, 17 May 1990, p.11, cited in Chari, P.R. et al. (2003). Perception, Politics and Security in South Asia: The Compound Crisis of 1990. RoutledgeCurzon, Taylor \& Francis Group London and New York, p. 73.

FBI (2009). Testimony Donald Van Duyn Chief Intelligence Officer Federal Bureau of Investigation Statement Before the Senate Committee on Homeland Security and Governmental Affairs Washington, DC. 8 January 2009 [online] Available at: https://archives.fbi.gov/archives/news/testimony/fbi-role-in-mumbai-investigation [Accessed 28.03.2017].

Fineman, M. (1990). India's Leader Warns of an Attack by Pakistan: War fears: Trouble in Kashmir and terrorism have raised tensions. Internal political unrest in both nations could push them toward conflict. Los Angeles Times, 15 April 1990. [online] Available at: http://articles.latimes.com/1990-04-15/news/mn-1984_1_political-unrest [Accessed 28.03.2017].

Foreign Affairs Record (New Delhi) (Jan 1966) 9-10 comp. Rajendra Kumar Jain. 
(1979). Soviet South Asian Relations 1947-1978. UK: Martin Robertson \& Company Ltd., pp. 95-98.

Foreign Broadcasting Information Service Daily Report Soviet Union (FBIS-DRSU). 2 December 1986, pp. D29. cited in Keshav Mishra (2004). Rapprochement Across the Himalayas: Emerging Indo-China Relations in Post Cold War Period (1947-2003). Delhi: Kalpaz Publications, p. 143.

Foreign Relations of the United States Office of the Historian (hereafter FRUS) (1947). The British Commonwealth; Europe, Volume III Telegram 845.00/10 - 2847 Sent by The Charge in Pakistan (Lewis) to the Secretary of State Karachi. 28 October 1947, pp. 179180. [online] Available at: https://history.state.gov/historicaldocuments/frus1947v03/d119 [Accessed 27.03.2017].

Freedman, L. (1981/1989). The Evolution of Nuclear Strategy. The International Institute of Peace Studies, London: The Macmillan Press Ltd., Printed in the People's Republic of China.

Freedman, R. O. (2001). Russian Policy toward the Middle East: The Yeltsin Legacy and the Putin Challenge, Middle East Journal, Vol. 55, No. 1, (Winter, 2001), pp. 58-90.

Freeze, C. (2011). Accused in India massacre claims ties to Pakistani secret service The Globe and Mail. 11 April 2011 [online] Available at: http://www.theglobeandmail.com/news/world/americas/accused-in-india-massacre-claimsties-to-pakistani-secret-service/article1981052/ [Accessed 28.03.2017].

Friedberg, A.L. (1993/1994). Ripe for Rivalry: Prospects for Peace in a Multipolar World. International Security, Volume 18, Number 3, Winter 1993/1994, pp. 5-33.

FRUS (1947, The British Commonwealth; Europe, Volume III). Memorandum of Conversation, by the Acting Secretary of State 845.00/10-747 7 October 1947 [online] Available at: https://history.state.gov/historicaldocuments/frus 1947v03/pg_167 [Accessed 27.03.2017].

FRUS (1947, Volume III, The British Commonwealth; Europe). The Telegram from The Acting Secretary of State to the Embassy in India 2 December 1947, 501.BB/12 - 247: Telegram [online] Available at: https://history.state.gov/historicaldocuments/frus1947v03/d121\#fnref:1.3.2.2.10.5.6.7.4 [Accessed 27.03.2017].

FRUS (1961-1963, Volume XIX, South Asia) Memorandum From the President's Deputy Special Assistant for National Security Affairs (Kaysen) to President Kennedy Washington. 9 November 1962 [online] Available at: 
https://history.state.gov/historicaldocuments/frus1961-63v19/d192 [Accessed 28.03.2017].

FRUS (1961-1963, Volume XIX, South Asia) Telegram From the Department of State to the Embassy in India, Washington. 28 October 1962 [online] Available at: https://history.state.gov/historicaldocuments/frus1961-63v19/d187 [Accessed 28.03.2017].

FRUS (1961-1963, Volume XIX, South Asia) Telegram from the Department of State to the Embassy in India. 20 November 1962 [online] Available at: https://history.state.gov/historicaldocuments/frus1961-63v19/d206 [Accessed 25.03.2017].

FRUS (1961-1963, Volume XIX, South Asia) Telegram From the Embassy in India to the Department of State. 29 October 1962 [online] Available at: https://history.state.gov/historicaldocuments/frus1961-63v19/d188 [Accessed 27.03.2017].

FRUS (1961-1963, Volume XIX, South Asia) Telegram From the Embassy in India to the Department of State New Delhi. 19 November 1962 [online] Available at: https://history.state.gov/historicaldocuments/frus1961-63v19/d203\#fn:1.3.2.2.282.4.5 [Accessed 28.03.2017].

FRUS (1964-1968, Volume XXV, South Asia). Memorandum From Robert Komer of the National Security Council Staff to President Johnson in Document 134. 21 June 1965 [online] Available at: https:/history.state.gov/historicaldocuments/frus1964-68v25/d134 [Accessed 27.03.2017].

FRUS (1964-1968, Volume XXV, South Asia). Telegram from McConaughy to Department of State [online] Available at: https://history.state.gov/historicaldocuments/frus1964-68v25/d114 [Accessed 27.03.2017].

FRUS (1964-1968, Volume XXV, South Asia). Telegram From the Embassy in India to the Department of State, Document 177 [online] Available at https://history.state.gov/historicaldocuments/frus 1964-68v25/d177 [Accessed 27.03.2017].

FRUS (1969-1976 Volume XI, South Asia Crisis, 1971). Document 101, 12 July 1971 [online] Available at: http:/history.state.gov/historicaldocuments/frus1969-76v11/d101 [Accessed 27.03.2017].

FRUS (Volume E-7 Documents on South Asia 1969-1972). Document 136, 4 June 1971 [online] Available at: http://history.state.gov/historicaldocuments/frus 1969-76ve07/d136 [Accessed 27.03.2017].

FRUS (Volume XI, South Asia Crisis 1971) Memorandum from Secretary of State Rogers to President Nixon. 26 May 1971 [online] Available at: http:/history.state.gov/historicaldocuments/frus1969-76v11/d58 [Accessed 27.03.2017].

FRUS (Volume XXV, South Asia Editorial Note 1964-1968) Document 193 [online] 
Available at: https://history.state.gov/historicaldocuments/frus1964-68v25/d193 [Accessed 27.03.2017].

FRUS (Volume XXV, South Asia) Telegram from the Department of State to the Embassy in India, Document 192, 8 September 1965 [online] Available at: https://history.state.gov/historicaldocuments/frus1964-68v25/d192 [Accessed 27.03.2017].

FRUS (Volume $X X V$, South Asia) Telegram from the Embassy in India to the $\begin{array}{llllll}\text { Department } & \text { of } & \text { State } & 11 & \text { September } & 1965\end{array}$ https://history.state.gov/historicaldocuments/frus1964-68v25/d201 [Accessed 29.03.2017].

FRUS (Volume XXV, South Asia) Telegram from the US Embassy to the Department of State, Document 198, 9 September 1965 [online] Available at: https://history.state.gov/historicaldocuments/frus1964-68v25/d198 [Accessed 27.03.2017].

FRUS (Volume XXV, South Asia). Memorandum from Secretary of State Rusk to $\begin{array}{lllll}\text { President } & \text { Johnson, } & 9 & \text { September } & 1965\end{array}$ https://history.state.gov/historicaldocuments/frus1964-68v25/d196 [Accessed 21.03.2017].

FRUS (Volume XXV, South Asia). Telegram From the Embassy Office in Pakistan to the Department of State, Document 217, 20 September 1965 [online] Available at: https:/history.state.gov/historicaldocuments/frus 1964-68v25/d217 [Accessed 29.03.2017].

FRUS. (1947, The British Commonwealth; Europe, Volume III) Telegram 745.45F/122947 Telegram Sent by the Acting Secretary of State to the Embassy in India, 31 December 1947 [online] Available at: https://history.state.gov/historicaldocuments/frus1947v03/pg_192 [Accessed 27.03.2017].

FRUS. (1947, The British Commonwealth; Europe, Volume III). 845.00/11-347: Telegram The Ambassador in India (Grady) to the Secretary of State. 3 November 1947 [online] Available at: https://history.state.gov/historicaldocuments/frus 1947v03/d120\#fn:1.3.2.2.10.5.5.8.18 [Accessed 26/03/2017].

FRUS. (1964-1968 Volume XXV, South Asia). Memorandum From Robert Komer of the National Security Council Staff to President Johnson Document 128, 8 June 1965 [online] Available at: https:/history.state.gov/historicaldocuments/frus1964-68v25/d128 [Accessed 27.03.2017].

FRUS. (1969-1976 Volume XI South Asia Crisis 1971) Letter from Indian Prime Minister Gandhi to President Nixon. 5 December 1971 [online] Available at: https://history.state.gov/historicaldocuments/frus1969-76v11/d226 [Accessed 27.03.2017].

FRUS. (1969-1976, Volume XI, South Asia Crisis 1971) Memorandum of 
Conversation. 3 June 1971 [online] Available at: https://history.state.gov/historicaldocuments/frus1969-76v11/d64 [Accessed 27.03.2017].

G8 Information Center (1999). G8 Statement on Regional Issues, Köln, Germany. 20 June 1999 [online] Available at: http://www.g8.utoronto.ca/summit/1999koln/regional.htm\#top [Accessed 28.03.2017].

Ganguly, S (1994). The Origin of War in South Asia: Indo - Pakistani Conflicts Since 1947. Colorado, the US and Oxford, the UK: Westview Press, Inc.

Ganguly, S. (2008). Nuclear Stability in South Asia. International Security, Vol. 33, No.2, Fall 2008, pp. 45-70.

Geller, D.S. (1990). Nuclear Weapons, Deterrence, and Crisis Escalation. The Journal of Conflict Resolution, Vol. 34, No.2, Jun 1990, pp. 291-310.

Global Security.org - Military - Indo-Pakistani War of 1971. [online] Available at: http://www.globalsecurity.org/military/world/war/indo-pak_1971.htm [Accessed 27.03.2017].

Global Security.org 1999 Kargil War [online] Available at: http:/www.globalsecurity.org/military/world/war/kargil-99.htm [Accessed 28.03.2017].

Goodpaster, A. J.et al. (1997). Post-Cold War Conflict Studies Naval Studies Board National Research Council Washington D.C.: National Academy Press.

Gorbachev, M. (1995). Zhizn i reformy Vol. 1, Moscow: Novosti. p. 218, cited in Bacon, E. (2002). Reconsidering Brezhnev in Edwin Bacon and Mark Sandle (eds.) Brezhnev Reconsidered, New York: Palgrave Macmillan.

Gorshkov, N. (2003). Pakistan begins ' new chapter' with Russia BBC News World Edition 6 February 2003, Thursday [online] Available at: http://news.bbc.co.uk/2/hi/south_asia/2734383.stm [Accessed 27.03.2017].

Greig, M.J., and Regan, P.M. (2008). When Do They Say Yes? An Analysis of the Willingness to Offer and Accept Mediation in Civil Wars. International Studies Quarterly, Vol. 52, No.4, December 2008, pp. 759-781.

Gupta, S. (2002). When India came close to war. Twice in 2002, India was on the verge of striking against Pakistan. India Today, 23 December 2002. [online] Available at: http://indiatoday.intoday.in/story/twice-in-2002-india-was-on-the-verge-of-striking-againstpakistan/1/218109.html [Accessed 28.03.2017].

Hagerty, D.T. (1995-1996). Nuclear Deterrence in South Asia: The 1990 Indo Pakistani Crisis. International Security, Vol. 20, No.3, Winter 1995 - 1996, The MIT Press, pp. 79-114.

Hagerty, D.T. (1998). The Consequences of Nuclear Proliferation: Lessons from South 
Asia. Cambridge, MA: The MIT Press.

Haider, M. (2002). Islamabad refuses to accept 'no first strike' doctrine Dawn [online] Available at: https://www.dawn.com/news/38860/islamabad-refuses-to-accept-no-first-strikedoctrine [Accessed 24.03.2017].

Heisbourg, F. (1998). The Prospects for Nuclear Stability between India and Pakistan. Survival, Volume 40, Issue 4, pp. 77-92.

Hersh, S. (1993). On the Nuclear Edge. 29 March 1993. The New Yorker [online] Available at: http://www.newyorker.com/magazine/1993/03/29/on-the-nuclear-edge [Accessed 29.03.2017].

Hindu (2002). We'll Unleash a Storm: Musharraf. 30 May 2002. The Hindu [online] Available at: http://www.thehindu.com/2002/05/30/stories/2002053008180101.htm [Accessed 28.03.2017].

Hindu, 17 June 1987 cited in Mishra, K. (2004). Rapprochement Across the Himalayas: Emerging Indo -China Relations in Post-Cold War Period (1947 - 2003). India: Kalpaz Publications, p. 64.

Hoffmann, S.A. (1990). India and the China Crisis. The US and the UK: University of California Press.

Horn, R.C. (1983). Afghanistan and the Soviet - Indian Influence Relationship, Asian Survey, Vol. 23, No. 3 (March, 1983), University of California Press, pp. 244 - 260.

Housego, D. (1990). India Urged to Attack Camps in Pakistan Over Strife in Kashmir Financial Times, 9 April 1990, cited in Chari, P. R. Chari (et al.) (2003). „Perception, Politics, and Security in South Asia: The Compound Crisis of 1990. RoutledgeCurzon, Taylor \& Francis Group London and New York, p. 75.

Hsinhua (Xinhua) News Agency, 9 December 1971 comp. Rajendra Kumar Jain (1981) China - South Asian Relations 1947-1980 Document 201, The Great Britain: The Harvester Press, John Spiers, pp. 229-230.

India News (1982). Press Report on Alleged Indian Military Plans - ' Figment of Imagination ' - Envoy, 27 December 1982 p.1 cited from Perkovich, G. (1999). India's Nuclear Bomb: The Impact on Global Proliferation Berkeley and Los Angeles. California: the University of California Press, p. 240.

India Today (1990). The Enemy Within. 'It is perhaps a singular Indian trait to look for scapegoats.' 31 March 1990 [online] Available at: http://indiatoday.intoday.in/story/it-isperhaps-a-singular-indian-trait-to-look-for-scapegoats/1/316403.html [Accessed 28.03.2017].

India Today (2011). India, China to restore defence cooperation. 13 April 2011. 
[online] Available at: http://indiatoday.intoday.in/story/india-china-to-restore-defence-cooperation/1/135160.html [Accessed 29.03.2017].

Inter Press Service (1987). India: Pakistani and Indian Troops To Pull Back Immediately. 4 February 1987, NEXIS.

Inter Press Service India (IPS): We Will Not Be Pushed Around, Says Gandhi. 20 January 1987, New Delhi, NEXIS

ITAR-TASS, A speech to a congress of the Civic Union, a center-right alliance, 1 March 1993 cited in Adomeit, H. (1995). Russia as 'Great Power' in World Affairs, International Affairs, Vol. 71, No. 1 (January 1995), Wiley on behalf of the Royal Institute of International Affairs, pp. 46-47.

Izvestia (1994). Moskva razrabotala programmu za zashchity 30 millionov russkikh v blizhnem zarubezh'e,', 17 February 1994, cited in Adomeit, H. (1995). Russia as 'Great Power' in World Affairs, International Affairs, Vol. 71, No. 1 (January 1995), Wiley on behalf of the Royal Institute of International Affairs, pp. 47-48.

Izvestia (1993). Perspektivy rasshireniia NATO i interesy Rossii. Doklad sluzhby vneshnei razvedki', 26 November I993, cited in Adomeit, H. (1995). Russia as 'Great Power' in World Affairs, International Affairs, Vol. 71, No. 1 (January 1995), Wiley on behalf of the Royal Institute of International Affairs, p. 49

J.K. Galbraith, n.11, p. 386, cited in Mishra, K. (2004). Rapprochement Across the Himalayas: Emerging Indo - China Relations in Post-Cold War Period (1947 - 2003). India: Kalpaz Publications, p. 124.

Jervis, R. (1976). Perception and Misperception in International Politics. The US: Princeton University Press.

Jervis, R. (1984). The Illogic of American Nuclear Strategy. Cornell University Press: Ithaca, New York.

Jetly, N. (1986). Sino-Indian relations: a quest for normalization. India Quarterly, Vol. 42, Issue. 1, January 1986, pp. 53-68.

Jiao, W. and Yunbi, Z. (2013). Xi proposes a 'new Silk Road`with Central Asia. China Daily USA, 08 September 2013 [online] Available at: http://usa.chinadaily.com.cn/china/201309/08/content_16952304.htm [Accessed 27.03.2017].

Joeck, N. (1997). Maintaining Nuclear Stability in South Asia. Adelphi Paper 312, London and New York: Routledge: Taylor \& Francis Group.

Joshi, M. (1999). Warrior as Scholar. General Krishnaswami Sundarji passes away. 
India Today, Obituary 22 February 1999 [online] Available at:

https://www.indiatoday.in/magazine/obituary/story/19990222-general-krishnaswami-sundarjipasses-away-780260-1999-02-22 [Accessed 16.02.2018].

Kahn, H. (1960). On Thermonuclear War. The US: Princeton University Press.

Kargil Review Committee (2000). From Surprise to Reckoning: The Kargil Review Committee Report, New Delhi: SAGE Publications.

Keatley, Patrick (1965). The Brown Bomb, Manchester Guardian 11 March 1965 cited in John L. Espesito, Tamara Sonn, and John O. Voll. (2016). Islam and Democracy After the Arab Spring. New York: Oxford University Press, p. 86.

Keesing's Contemporary Archives 1955-56, p. 14604 cited in Das Gupta, J.B. (1968) Jammu and Kashmir The Hague: Martinus Nijhoff, p. 222.

Keesing's Contemporary Archives, 1955-56, p. 14654 cited in Das Gupta, J.B. (1968) Jammu and Kashmir, p. 222.

Khan, Feroz H. (2012). Eating Grass: The Making of the Pakistani Bomb. Stanford, CA: Stanford University Press.

Khan, M. Z. and Emmerson, J.K. (1954). United States - Pakistan Mutual Defense Assistance Agreement: Middle East Journal, Vol. 8, No. 3, 19 May 1954, pp. 338-340.

Khan, S. (2009). Nuclear Weapons and Conflict Transformation: The case of IndiaPakistan. The USA and Canada: Routledge.

Krepon, M and Faruqee, M. (eds.) (1994). Conflict Prevention and ConfidenceBuilding Measures in South Asia: The 1990 Crisis. The Henry L. Stimson Center Occasional Paper No. 17 April 1994. [Online] https://www.stimson.org/sites/default/files/fileattachments/occasionalpaper17-web_1.pdf p. 3 [Accessed 23.03.2017].

Kulikov, V. (2002). Atal Vadhzpai:' My s Putinym Obsudim Vse Klyuchevye Voprosy',, [Atal Vajpayee: We have discussed all key issues with Putin]. Izvestia, 3 December 2002, p. 4 cited in Martin Malek (2004). Russian Policy toward South Asia: An Update. Asian Survey, Vol. 44, No.3, May/June 2004, University of California Press, p. 389.

Kydd, A. (2003). Which Side Are You On? Bias, Credibility, and Mediation. American Journal of Political Science, Vol. 47, No.4, October 2003, p. 597-611.

Labelle, G.G. (1987). India - Pakistan Tempestuous Teapot Slightly Less Steamy. The Associated Press, 6 February 1987, NEXIS.

Lakshmi, R. (2001). Gunmen With Explosives Attack Indian Parliament. Washington Post, 14 December 2001, A-1 cited in Nayak, P and Krepon, M. (2006). US Crisis Management In South Asia's Twin Peaks Crisis The Henry L. Stimson Center, Report 57 
September 2006, p. 15.

Lakshmi, R. (2001). Indians Blame Attacks on Pakistan-Based Group. Washington Post, 15 December 2001, A-23, cited in Nayak, P and Krepon, M. (2006). US Crisis Management In South Asia's Twin Peaks Crisis The Henry L. Stimson Center, Report 57 September 2006, p. 15.

Lakshmi, R. (2012). India Hangs Lone Surviving Terrorist from 2008 Mumbai

Attacks. The Washington Post, 21 November 2012 [online] Available at: https://www.washingtonpost.com/world/asia_pacific/india-hangs-lone-surviving-terroristfrom-2008-mumbai-attacks/2012/11/21/ad02d6fe-3412-11e2-bfd5-e202b6d7b501_story.html [Accessed 28.03.2017].

Lamb, A. (1966). Crisis in Kashmir 1947 to 1966. London: Routledge \& Kegan Paul.

Landay, J.S. (1987). India and Pakistan Continue Talks on Border Tensions. 3 February 1987, United Press International [online] Available at: http://www.upi.com/Archives/1987/02/03/India-and-Pakistan-continue-talks-on-bordertensions/1058539326800/ [Accessed 27.03.2017].

Landay, J.S. (1987). India and Pakistan Continue Talks on Border Tensions. United Press International, 3 February 1987 [online] Available at: http://www.upi.com/Archives/1987/02/03/India-and-Pakistan-continue-talks-on-bordertensions/1058539326800/ [Accessed 27.03.2017].

Lebow, R.N. (1981). Between Peace and War: The Nature of International Crisis. the US: John Hopkins University Press.

Left, S. (2002). Indian PM calls for 'decisive battle` over Kashmir. The Guardian, 22 May 2002 [online] http://www.theguardian.com/world/2002/may/22/kashmir.india [Accessed 28.03.2017].

Levy, A. and Scott-Clark, C. (2007). Deception: Pakistan, the United States and the Global Nuclear Weapons Conspiracy. Great Britain: Atlantic Books, Grove Atlantic Ltd.

Lingam, T.S.K. (1987). India - Pakistan Sign Accord. United Press International 4 February 1987 [online] Available at: http://www.upi.com/Archives/1987/02/04/IndiaPakistan-sign-accord/2504539413200/ [Accessed 27.03.2017].

Loeb, V. (2002). Footprints in Steppes of Central Asia. The Washington Post, 9 February 2002 [online] Available at: https://www.washingtonpost.com/archive/politics/2002/02/09/footprints-in-steppes-of-centralasia/93c3703c-9bf1-4137-967b-e51bf83e3e5a/ [Accessed 26.03.2017].

Lok Sabha Debate (2009). The Minister of External Affairs made a statement 
regarding 'Follow-Up to Mumbai Terrorist Attack.' LT 10458-A/09 [online] Available at: https://indiankanoon.org/doc/339019/ [Accessed 28.03.2017].

Lowy Institute for International Policy South China Sea: Conflicting Claims and Tensions. [online] Available at: http://www.lowyinstitute.org/issues/south-china-sea [Accessed 29.03.2017].

Manoharan, M. (1990). Indian Leader Tells Pakistan to Stay Out of Kashmir Uprising Reuters Library Report, 13 March 1990 cited in Chari, P. R. et al. (2003). Perception, Politics, and Security in South Asia: The Compound Crisis of 1990. London and New York: RoutledgeCurzon, Taylor \& Francis Group, p. 74.

Manoj Joshi, "From Maps to Field” The Hindu. 29 March 1987, cited in Bajpai, K.P. et al. (1997). Brasstacks and Beyond: Perception and Management of Crisis in South Asia. New Delhi: Ajay Kumar Jain Manohar Publishers \& Distributers, p. 157.

Mansingh, S. (1994). India - China Relations in the Post-Cold War. Asian Survey, Vol. 34, No.3, March 1994, University of California Press, pp. 285-300.

Marantidou, V. and Cossa, R.A. (2014). The Great Game in Central Asia. Pacific Forum Center for Strategic \& International Studies, (CSIS) PacNet Number 73, 29 September 2014 [online] Available at: https://www.csis.org/analysis/pacnet-73-great-game-central-asia [Accessed 27.03.2017].

Masood, S. (2009). Pakistan Says 124 Arrested in Mumbai Investigation. New York Times, 15 January 2009 [online] Available at: http://www.nytimes.com/2009/01/16/world/asia/16pstan.html [Accessed 14.03.2017].

Maxwell, Neville (1999). Sino-Indian Border Dispute Reconsidered. Economic and Political Weekly, Vol. 34, No. 15 10-16 April 1999, pp. 905-918.

MccGwire, M. (2000). The Elimination of Nuclear Weapons in John Baylis and Robert O`Neill (eds.) Alternative Nuclear Futures: The Role of Nuclear Weapons in the PostCold War. New York: Oxford University Press, pp. 144-166.

Ministry of External Affairs Government of India Documents Kaluchak Massacre, 14 May 2002 [online] Available at: http://mea.gov.in/in-focusarticle.htm?18990/Kaluchak+Massacre+14+May+2002 [Accessed 23.03.2017].

Ministry of External Affairs Government of India. White Paper III November 1959 March 1960: Notes, Memoranda and Letters Exchanged and Agreements signed between the Governments of India and China, Sino-Indian Boundary Disputes No. 11, Note of the Chinese Government, 26 December 1959 in Claude Arpi Historical Documents White Papers on China [online] Available at: http://www.claudearpi.net/wp- 
content/uploads/2016/12/WhitePaper3NEW.pdf [Accessed 23.03.2017].

Ministry of External Affairs, Bangladesh Documents, Volume III, 160-1 comp. by Rajendra Kumar Jain Soviet-South Asian Relations 1947-1978 Volume 1. Podgorny`s Speech at a dinner in honour of the King of Afghanistan, 14 September 1971 UK: Martin Robertson \& Company Ltd, pp. 121-122.

Ministry of External Affairs, Government of India Annual Reports 1965-66. pg. 10 [online] Available at: http://mealib.nic.in/?pdf2492?000 [Accessed 27.03.2017].

Ministry of External Affairs, Government of India Annual Reports 1965-66. p. 10 [online] Available at: http://mealib.nic.in/?pdf2492?000 [Accessed 27.03.2017].

Ministry of Foreign Affairs of the People's Republic of China Ambassador Liu Xiaoming gives interview to Reuters on the South China Sea 7 July 2016[online] Available at:

http://www.fmprc.gov.cn/mfa_eng/wjb_663304/zwjg_665342/zwbd_665378/t1378316.shtml [Accessed 23.03.2017].

Ministry of Foreign Affairs of the People's Republic of China Chinese. US FMs Discuss India-Pak Situation by Phone. [online] Available at: http://www.fmprc.gov.cn/wjb/eng_search.jsp [Accessed 26.03.2017].

Ministry of Foreign Affairs of the People's Republic of China Vice Foreign Minister Liu Zhenmin at the Press Conference on the White Paper Titled China Adheres to the Position of Settling Through Negotiation the Relevant Disputes Between China and the Philippines in the South China Sea, 13 July 2016 [online] Available at: http://www.fmprc.gov.cn/mfa_eng/wjbxw/t1381980.shtml [Accessed 24/03/2017].

Ministry of Foreign Affairs of the Russian Federation Official Website. Speech by Russian Foreign Minister Igor Ivanov at an Enlarged Meeting of Foreign Minsiters of StatesParticipants in the Shanghai Cooperation Organization. 06 May 2002 [online] Available at: http:/www.mid.ru/en/web/guest/sanhajskaa-organizacia-sotrudnicestva-sos-//asset_publisher/0vP3hQoCPRg5/content/id/557702 [Accessed 31.03.2017].

Ministry of Foreign Affairs of the Russian Federation Official Website. Press Release The Answer of the Official Spokesman of the Russian Federation Foreign Ministry Alexander Yakovenko to an ITAR-TASS Question in Connection with the Terrorist Act in the Indian State of Jammu and Kashmir. 17 May 2002 [online] Available at: http://www.mid.ru/en/maps/in/-/asset_publisher/EpJ5G4lcymvb/content/id/557142 [Accessed 31.03.2017].

Ministry of Foreign Affairs of the Russian Federation Official Website. Press Release 
On Moves by Indian Leadership, Aimed at Reducing Tension in South Asia Region. 12 June 2002 [online] Available at: http://www.mid.ru/en/web/guest/maps/in//asset_publisher/EpJ5G4lcymvb/content/id/553876 [Accessed 31.03.2017].

Ministry of Foreign Affairs of the Russian Federation Official Website. Russian Minister of Foreign Affairs Igor Ivanov Meets with US Secretary of State Colin Powell. 13 June 2002 [online] Available at: http://www.mid.ru/en/web/guest/foreign_policy/international_safety/crime//asset_publisher/3F51ZsLVSx4R/content/id/553940 [Accessed 31.03.2017].

Ministry of Foreign Affairs of the Russian Federation Official Website. Article Written by Russian Minister of Foreign Affairs Igor Ivanov, „Russia and India: Together in the Struggle Against International Terrorism. The Strategic Partnership in Action. „, Published in the Newspaper Rossiiskaya Gazeta. 2 December 2002, [online] Available at: http://www.mid.ru/en/web/guest/foreign_policy/international_safety/crime//asset_publisher/3F51ZsLVSx4R/content/id/537910 [Accessed 31.03.2017].

Ministry of Foreign Affairs of the Russian Federation Official Website, Press Release On the Terrorist Acts in Mumbai. 27 November 2008 [online] Available at: http://www.mid.ru/en/web/guest/maps/in/-/asset_publisher/EpJ5G4lcymvb/content/id/315104 [Accessed 31.03.2017].

Ministry of Foreign Affairs of the Russian Federation Official Website. Foreign Policy Fundamental Documents National Security Concept of the Russian Federation 10 January 2000, Approved by Presidential Decree No. 24. [online] Available at: http://www.mid.ru/en/foreign_policy/official_documents//asset_publisher/CptICkB6BZ29/content/id/589768 [Accessed 23.01.2018].

Ministry of Foreign Affairs of the Russian Federation Official Website Statement of the Russian Ministry of Foreign Affairs, 27 December 2008 [online] Available at: http://www.mid.ru/en/web/guest/maps/pk//asset_publisher/GSALcG2HPipT/content/id/311206 [Accessed 28.03.2017].

Mishra, K. (2004). Rapproachment Across the Himalayas: Emerging Indo - China Relations in Post Cold War Period (1947 - 2003). India: Kalpaz Publications.

Mohanty, A. (2015). Six decades since Nehru's first official USSR visit. Russia \& India Report, 2 July 2015 [online] Available at:

https://in.rbth.com/arts/2015/07/02/six_decades_since_nehrus_first_official_ussr_visit_44003 [Accessed 27.03.2017].

Morgan, P.M. (1977). Deterrence: A Conceptual Analysis. The US and the UK: SAGE 
Publications.

Morgan, P.M. (2012). The State of Deterrence in International Politics Today. Contemporary Security Policy, Vol 33, Issue 1, 13 April 2012, pp. 85-107.

Moskalenko, V. (2002). “Eksperty 'NG': 'Esli Konflikt ne Pogasit, Destabilizatsiya Grozit Vsemu Regionu'" ('NG' experts: "If we do not succeed in resolving the conflict, the entire region could be destabilized."). Nezavisimaya Gazeta, 5 June 2002 in Martin Malek (2004). Russian Policy toward South Asia: An Update Asian Survey, Vol. 44, No.3, May/June 2004, University of California Press, p. 388.

Mueller, J. (1988). The Essential Irrelevance of Nuclear Weapons: Stability in the Postwar World. International Security, Vol. 13, No. 2, Fall 1988, pp. 55-79.

Mueller, K.P. et.al. (2006). Striking First: Preemptive and Preventive Attack in U.S. National Security Policy the US: RAND Cooperation [online] Available at: http://www.rand.org/content/dam/rand/pubs/monographs/2006/RAND_MG403.pdf [Accessed 23.03.2017].

Mydans, S. (2002). Musharraf Treading Gently Against Pakistani Militants. The New York Times, 28 April 2002 [online] Available at: http://www.nytimes.com/2002/04/28/world/musharraf-treading-gently-against-pakistanimilitants.html?_r=0 [Accessed 28.03.2017].

Nair, D., Desai, S. et al. (2008). Tracing the Terror. The Indian Express, 10 December 2008 [online] Available at: http://archive.indianexpress.com/news/tracing-the-terrorroute/396335/1 [Accessed 19.08.2016].

National Security Archive The George Washington University (hereafter NSARCHIVE), Memorandum for Interagency Intelligence Working Group on Nuclear Proliferation from John Despres National Intelligence Officer Monthly Warning Report. 18 January 1979, Top Secret, excised copy Source: CREST from National Security Archive, p. 2 [online] Available at: http://nsarchive.gwu.edu/nukevault/ebb333/doc22.pdf [Accessed 27.03.2017].

Nawa-e-Wagt, 5 October 1984, translated in U.S. Embassy (Islamabad) to Secretary of State, cable no.080951Z, October 1984, p.2, in FOIA files Pakistan, National Security Archive, Washington, D.C. cited from Perkovich, G. (1999). India's Nuclear Bomb: The Impact on Global Proliferation. Berkeley and Los Angeles, California: the University of California Press, p. 258.

Nayak P. and Krepon, M. (2006). US Crisis Management in South Asia's Twin Peak Crisis Report 57, Washington, DC.: Stimson Center. 
New York Times International (1959). Dalai Lama Gets Asylum in India; Harried in Flight: Special to the New York Times, 4 April 1959 [online] Available at: https://partners.nytimes.com/library/world/asia/040459atibet-special.html [Accessed 21.03.2017].

New York Times, 22 October 1962 cited in Michael Brecher (1979-80). NonAlignment Under Stress: The West and the India-China Border War Pacific Affairs, Vol. 52, No.4. (Winter, 1979-1980). Pacific Affairs, University of British Columbia, p. 613.

Noorani, A.G. (1999). `An Aborted Deal? `Frontline, India\& Pakistan, Volume 16, Issue 18, 28 August - 10 September 1999 [online] Available at: http://www.frontline.in/static/html/fl1618/16180310.htm [Accessed 28.03.2017].

Noorani, A.G. (2002). The Truth about the Lahore Summit. Frontline, Analysis Volume 19 Issue 4, 16 February - 1 March 2002 [online] Available at: http://www.frontline.in/static/html/fl1904/19040850.htm [Accessed 23.03.2017].

Norman, T.L. (2009). Risk Analysis and Security Countermeasure Selection. Boca Raton: CRC Press Taylor \& Francis Group.

Note Verbale CML/17/2009 from the Permanent Mission of the People's Republic of China to the UN Secretary-General. New York, 7 May 2009 [online] Available at: http://www.un.org/depts/los/clcs_new/submissions_files/mysvnm33_09/chn_2009re_mys_vn m_e.pdf [Accessed 31.03.2017].

Note Verbale CML/8/2011 from the Permanent Mission of the People's Republic of China to the UN Secretary-General. New York, 14 April 2011 [online] Available at: http://www.un.org/depts/los/clcs_new/submissions_files/mysvnm33_09/chn_2011_re_phl_e.p df [Accessed 31.03.2017].

NSARCHIVE, A Telegram from the State Department to US Embassy, Beijing, South Asia Nuclear Problem: Exploratory Discussion with the PRC. 20 June 1979, excised copy cable 158902 Source: FOIA Request taken from [online] Available at: http://nsarchive.gwu.edu/nukevault/ebb333/doc38.pdf [Accessed 27.03.2017].

NSARCHIVE, A telegram from the US Embassy in New Delhi to State Department cable 9979 „India and the Pakistan Nuclear Program. 7 June 1970, Source: MDR Release taken from [online] Available at: http://nsarchive.gwu.edu/nukevault/ebb333/doc35b.pdf [Accessed 27/03/2017].

NSARCHIVE, Action Memorandum From Anthony Lake, Harold H. Saunders and Thomas R. Pickering to the Deputy Secretary of Department of State PRC Paper on South Asia enclosing Interagency Working Group Paper "South Asian Nuclear and Security 
Problems“, Analysis of Possible Elements in a U.S. Strategy. 23 March 1979 [online] Available at: http://nsarchive.gwu.edu/nukevault/ebb333/doc32a.pdf p. TAB A [Accessed 27/03/2017].

NSARCHIVE, Assistant Secretaries Harold Saunders, Thomas Pickering, and Anthony Lake through Mr. Christopher, Mr. Newsom, and Mrs. Benson to the Secretary, „, November 14 PRC Meeting on South Asian Nuclear Issues. 10 November 1979, Source: RG 59, Records of Anthony Lake, box, TL 11/1 - 11/15/70 taken from [online] Available at: http://nsarchive.gwu.edu/nukevault/ebb333/doc44.pdf p. 6 [Accessed 27.03.2017].

NSARCHIVE, Herald H. Saunders and Thomas R. Pickering The Memorandum of a Briefing to David D. Newsom Mini Policy Review Committee Meeting on the Pakistan Nuclear Program. 20 January 1979, p.3, Source: [online] Available at: http://nsarchive.gwu.edu/nukevault/ebb333/doc23a.pdf [Accessed 27.03.2017].

NSARCHIVE, Memorandum for Director and Deputy Director of Central Intelligence Agency from National Intelligence Officer for Warning David Y. McManis Monthly Warning and Forecast Meetings for July 1984 [online] Available at: http://nsarchive.gwu.edu/nukevault/ebb531-U.S.-Pakistan-Nuclear-Relations,-19841985/documents/doc\%203\%208-6-84\%20cia\%20warning.pdf [Accessed 27.03.2017].

NSARCHIVE, Memorandum from Gerard C. Smith, Special Representative of the President for Non-Proliferation Matters, to the Deputy Secretary. 27 March 1979, pp. 1-2. [online] Available at: http://nsarchive.gwu.edu/nukevault/ebb333/doc32c.pdf [Accessed 27.03.2017].

NSARCHIVE, Notes from the Politburo Session, 30 October 1986, by Anatoly Chernyaev, The Gorbachev Foundation Archive, Translated by Svetlana Savranskaya for the National Security Archive in NSARCHIVE The Reykjavik File, Document 23, USSR CC CPSU Politburo Session. [online] Available at: https://nsarchive2.gwu.edu/NSAEBB/NSAEBB203/index.htm and directly Available at: https://nsarchive2.gwu.edu/NSAEBB/NSAEBB203/Document23.pdf [Accessed 03.01.2018].

NSARCHIVE, Paul H. Kreisberg, Policy Planning Staff through David Newsom to the Deputy Secretary, “A Mediator for the South Asian Nuclear Program. 22 May 1979, Source: RG. 59 Records of Anthony Lake, box 5, 5/16-31/79. [online] Available at: http://nsarchive.gwu.edu/nukevault/ebb333/doc34a.pdf [Accessed 27.03.2017].

NSARCHIVE, The Memorandum of The Policy Review Committee Meeting on 22 January 1979, p. 2. Source: [online] Available at: http://nsarchive.gwu.edu/nukevault/ebb333/doc23c.pdf [Accessed 27.03.2017]. 
NSARCHIVE, University Marshall Shulman, Paul Kreisberg, and Robert Barry to David D. Newsom Mini Policy Review Committee Meeting on Pakistani Nuclear Intentions. 22 January 1979, Source, [online] Available at: http://nsarchive.gwu.edu/nukevault/ebb333/doc23b.pdf [Accessed 27.03.2017].

Observer [London] 1 March 1987 cited in Chari, P.R. (2003). Nuclear Crisis, Escalation Control, and Deterrence in South Asia. The Henry L. Stimson Center Working Paper Version 1.0, Washington DC. August 2003, p. 15. [online] Available at: https://www.stimson.org/sites/default/files/file-attachments/escalation_chari_1_1.pdf [Accessed 27.03.2017].

Oppel, R.A.Jr., and Masood, S. (2008). Pakistan Moves Troops Amid Tension With India. The New York Times, 26 December 2008 [online] Available at: http://www.nytimes.com/2008/12/27/world/asia/27pstan.html [Accessed 13.03.2017].

Pakistan Horizon, no.2, 2nd Quarter, 1971, 145-146 comp. by Rajendra Kumar Jain US-South Asian Relations 1947-1982. Statement by the Spokesman of the Department of State, Volume 3, p.3, Document 1, p. 3.

Pakistan National Security Archive A Telegram in from the US Embassy in Islamabad to Secretary of State cable no. 120926Z, October 1984, p.2 in FOIA files, Pakistan National Security Archive, Washington DC, cited from Perkovich, G. (1999). India's Nuclear Bomb: The Impact on Global Proliferation. Berkeley and Los Angeles. California: the University of California Press p. 258.

Pandit, R. (2014). Govt yet to notify Operation Falcon on China border after 28 years. The Times of India, 4 Sep 2014 [online] Available at: http://timesofindia.indiatimes.com/india/Govt-yet-to-notify-Operation-Falcon-on-Chinaborder-after-28-years/articleshow/41652458.cms [Accessed 18.03.2017].

Peking Review (1963). (Articles of Peking Review are taken from Marxist Internet Archive https://www.marxists.org/ and Massline.org http://massline.org/) The Origin and Development of the Differences Between the Leadership of the C.P.S.U. and Ourselves, Vol. 6, No. 37, 13 September 1963 [online] Available at: https://www.marxists.org/subject/china/peking-review/1963/PR1963-37.pdf [Accessed 21.03.2017].

Peking Review (1965). Indian Aggression Against Pakistan. 17 September 1965, No. 38 [online] Available at: https://www.marxists.org/subject/china/peking-review/1965/PR196538.pdf [Accessed 27.03.2017].

Peking Review (1965). Indian Reactionaries’ Expansionism. 10 September 1965, 
Observer, No.37 [online] Available at: http://massline.org/PekingReview/PR1965/PR196537.pdf [Accessed 27.03.2017].

Peking Review (1965). On the Indian-Pakistan Conflict. 8 October 1965, No. 41

[online] Available at: https://www.marxists.org/subject/china/peking-review/1965/PR196541.pdf [Accessed 27.03.2017].

Peking Review (1971). Chi Peng-fei’s Speech. 12 November 1971, Vol. 14, No.46 [online] Available at: https://www.marxists.org/subject/china/peking-review/1971/PR197146.pdf [Accessed 27.03.2017].

Peking Review (1971). China's Stand on Question of Refugees from East Pakistan. 26 November 1971, Vol. 14, No.48 [online] Available at:

https://www.marxists.org/subject/china/peking-review/1971/PR1971-48.pdf

[Accessed 31.03.2017].

Peking Review (1971). Condemning Soviet-Supported Indian Aggression Against Pakistan. 17 December 1971, Vol. 14, No.51 [online] Available at: https://www.marxists.org/subject/china/peking-review/1971/PR1971-51.pdf

[Accessed 27.03.2017].

Peking Review (1971). What Are Indian Expansionists Trying to Do? 16 April 1971, Vol.14, No.16 [online] Available at: https://www.marxists.org/subject/china/pekingreview/1971/PR1971-16.pdf [Accessed 27.03.2017].

People's Daily (2002). US FMs Discuss India-Pak Situation by Phone. 28 May 2002. [online] Available at: http://en.people.cn/200205/28/eng20020528_96586.shtml [Accessed 26.03.2017].

People 's Daily Online (2008). Chinese FM talks with Indian, Pakistani Counterparts over Phone. 27 December 2008 [online] Available at:

http://en.people.cn/90001/90776/90883/6562940.html [Accessed 28.03.2017].

Perkovich, G. (1999). India's Nuclear Bomb: The Impact on Global Proliferation. Berkeley and Los Angeles. California: the University of California Press.

Permanent Court of Arbitration Press Release. The South China Sea Arbitration: (The Republic of the Philippines v. The People's Republic of China). 12 July 2016 [online] Available at: https://pca-cpa.org/wp-content/uploads/sites/175/2016/07/PH-CN-20160712Press-Release-No-11-English.pdf [Accessed 24/09/2016].

Pifer, S., Bush, R.C., Felbab-Brown, V. et al. (2010). U.S. Nuclear and Extended Deterrence: Considerations and Challenges Brookings Arms Control Series, Paper No: 3, 2 May 2010 [online] Available at: https://www.brookings.edu/wp- 
content/uploads/2016/06/06_nuclear_deterrence.pdf [Accessed 15.02.2017].

Pikhoia, Rudolf G. (2004). "Pochemu raspalsia SSR?" in Konets kholodnoi voini: noviie fakti i aspekti, edited by V.M. Zubok , S.Y. Shenin, and A.A. Shubin. Saratov: Nauchnaia Kniga, 2004 cited in Zubok, V. M. (2009). A Failed Empire: The Soviet Union in the Cold War from Stalin to Gorbachev. The US: The University of North Carolina Press.

Pillalamarri, A. (2015). India's Nuclear Weapons Program: 5 Things You Need to

Know The National Interest. 22 April 2015 [online] Available at: http://nationalinterest.org/feature/indias-nuclear-weapons-program-5-things-you-need-know12697 [Accessed 27.03.2017].

Prasad, S.N. and Pal, D. (1987). Operations in Jammu \& Kashmir 1947-48. New Delhi: Controller of Publications, Ministry of Defence, History Division Government of India printed by Thomson Press (India) Limited.

Pravda (1962). The Present International Situation and the Foreign Policy of the Soviet Union," Report to Session of the Supreme Soviet of the USSR, 12 December 1962, 13 December 1962, in The Current Digest of the Soviet Press, Vol. XIV, No. 52 (January 23, 1963), p. 7 both cited in Michael Brecher (1979-80). Non-Alignment Under Stress Pacific Affairs, Vol. 52, No.4. Winter, 1979-1980 p. 619.

Pravda (Moscow). 10 August 1963, cited in Mishra, K. (2004). Rapproachment Across the Himalayas: Emerging Indo - China Relations in Post Cold War Period (1947 - 2003). India: Kalpaz Publications, p. 122.

Pravda TASS Statement. 9 May 1965, as translated in Daily Review (Moscow) comp. by Rajendra Kumar Jain. (1979) Soviet South Asian Relations 1947-1978. UK: Martin Robertson \& Company Ltd., p. 61.

President of Russia. Statement for the Press and Answers to Questions Following Negotiations with Indian Prime Minister Atal Bihari Vajpayee. 6 November 2001 [online] Available at: http://en.kremlin.ru/events/president/transcripts/21390 [Accessed 28.03.2017].

President of Russia. President Vladimir Putin met with Pakistan's President Pervez Musharraf, 4 June 2002, [online] http://en.kremlin.ru/events/president/news/27120 [Accessed 23.03.2017].

President of Russia. President Vladimir Putin met with Indian Prime Minister Atal Bihari Vajpayee, 4 June 2002, [online] http://en.kremlin.ru/events/president/news/27123 [Accessed 23.03. 2017]. 
President of Russia. President Vladimir Putin's News Conference with Indian Prime Minister Atal Bihari Vajpayee Summarizing Russian-Indian Negotiations, 3 October 2000, [online] http://en.kremlin.ru/events/president/transcripts/21593 [Accessed 23.01.2018].

Public Opinion Trends, Vol. XIV, No. 188. 13 October 1986, cited in Bajpai K.P. et al. (1997). Brasstacks and Beyond New Delhi: Ajay Kumar Jain Manohar Publishers \& Distributers, p. 158.

Rabasa, A, and Blackwill, R.D. et.al. (2009). The Lessons of Mumbai Occasional Paper RAND Cooperation [online] Available at:

https://www.rand.org/pubs/occasional_papers/OP249.html [Accessed 22.09.2017]

Raghavan, V.R. (2001). Limited War and Nuclear Escalation in South Asia. The Nonproliferation Review, Volume 8, Number 3, Fall/Winter 2001, pp. 1-18.

Rajya Sabha (2009). President's Address to both the Houses of Parliament assembled together on the 12th February 2009 [online] Available at: http://rajyasabha.nic.in/rsnew/session_journals/215/12022009.pdf [Accessed 02.03.2015].

Rauchhaus, R. (2009). Evaluating the Nuclear Peace Hypothesis: A Quantitative Approach. Journal of Conflict Resolution, Vol. 53, No. 2 April 2009, pp. 258-277.

Rediff (2001). Interview with General V. Prakash Malik, Part III `Kargil was a Good Wake Up Call 28 July 2001 done by Chindu Sreedharan and Josy Joseph [online] Available at: http://www.rediff.com/news/2001/jul/28inter.htm [Accessed 22.03.2017].

Reiss, M. (1995). Bridled Ambition. Baltimore: The John Hopkins University Press.

Reuters (2013). India says China agrees retreat to de facto border in faceoff deal. 6 May 2013, reported by Frank Jack Daniel, Michael Martina, Edited by Ron Popeski. [online] Available at: http://www.reuters.com/article/us-india-china-idUSBRE9440B220130506 [Accessed 28.03.2017].

Reuters (2015). U.S. Navy Destroyer nears islands built by China in South China Sea. 26 October 2015, [online] Available at: http://www.reuters.com/article/us-southchinasea-usaidUSKCN0SK2AC20151026 [Accessed 29.03.2017].

Reuters North European Service. 23 January 1987, cited in Bajpai K.P. et al. (1997). Brasstacks and Beyond pp. 82 and 167.

Reuters North European Service. 23 March 1987, cited in Bajpai K.P. et al. (1997). Brasstacks and Beyond, p. 179.

Rublee, M.R. (2009). Nonproliferation Norms: Why States Choose Nuclear Restraint. Athens, Georgia: The University of Georgia Press, pp. 21-28.

Sagan, S. and Waltz, K.N. (2003). Indian and Pakistani Nuclear Weapons: For Better 
or Worse? Chapter 3 in Scott D. Sagan and Kenneth N. Waltz The Spread of Nuclear Weapons. New York: W.W. Norton pp. 88-124.

Sagan, S.D. (1994). The Perils of Proliferation: Organization Theory, Deterrence Theory, and the Spread of Nuclear Weapons. International Security, Vol. 18, No. 4, pp. 66107.

Sarkar, B. (2016). Defense of Srinagar 1947. Indian Defense Review [online] Available at: http://www.indiandefencereview.com/interviews/defence-of-srinagar-1947/ [Accessed 27.03.2017].

Schelling, T.C. (1960). The Strategy of Conflict. The US: Harvard University Press.

Schlesinger, A.M. Jr. (1965). A Thousand Days: John F. Kennedy in the White House. Boston and New York: Mariner Book Houghton Mifflin Company.

Schofield, V. (2003). Kashmir in Conflict: India, Pakistan and the Unending War. New York and London: I.B. Tauris \& Co Ltd.

Shanker, T. and Bumiller, E. (2002). Citing Tension, U.S. Advises Americans in India to Leave. The New York Times, 1 June 2002 [online] Available at: http:/www.nytimes.com/2002/06/01/world/citing-tension-us-advises-americans-in-india-toleave.html [Accessed 24.03.2017].

Shaohui, T. (2015). Chronology of China's Belt and Road Initiative. Xinhuanet, 28 March 2015 [online] Available at: http://news.xinhuanet.com/english/201503/28/c_134105435.htm [Accessed 28.03.2017].

Shukla, J.P. (2002). No Weapon will be Spared for Self-Defence: PM 3. The Hindu, January [online] Available at: http://www.thehindu.com/thehindu/2002/01/03/stories/2002010303010100.htm [Accessed 23.03.2017].

Siddiqi, R.A. (2014). China's Evolving Posture in South Asia: Some Reflections. IPRI Journal XIV, no. 2, Summer, 2014: 1-19 [online] Available at: http://www.ipripak.org/wp-content/uploads/2014/10/1-article-s14.pdf [Accessed 28.03.2017].

Siddique-ul-Farooque, M. (2006). Kargil: Adventure or trap: White Paper: Lahore: Sagar Publishers.

Sidhu, W.P.S. The development of an Indian nuclear doctrine since 1980, p. 331 cited from Perkovich, G. (1999). India 's Nuclear Bomb, p. 240.

Singh, A.I. (2015). Unequal Partners: China and Russia in Eurasia. The Diplomat, 03 June 2015 [online] Available at: http://thediplomat.com/2015/06/unequal-partners-china-andrussia-in-eurasia/ [Accessed 28.03.2017]. 
Singh, J. (1998). Against Nuclear Apartheid. Foreign Affairs, Vol. 77, No.5, SeptOctober 1998, pp. 41-52.

Singh, J. (2011). Indian Air Power in John Andreas Olsen (ed.) Global Air Power. The US: Potomac Books, Inc.

Singh, Karan (1982). Heir Apparent. Oxford: Oxford University Press.

Slim, R.M. (1992). Small-State Mediation in International Relations: The Algerian Mediation of the Iranian Hostage Crisis in Jacob Bercovitch and Jeffrey Z. Rubin (eds.) Mediation in International Relations: Multiple Approaches to Conflict Management. New York: Palgrave Macmillan, p. 206-231.

Snyder, G.H. (1961). Deterrence and Defense: Toward a Theory of National Security. The US: Princeton University Press.

Snyder, G.H. (1965). The Balance of Power and the Balance of Terror in Paul Seabury (ed.) The Balance of Power. Scranton: Chandler, pp. 184-201.

Snyder, G.H. and Diesing, P. (1977). Conflict Among Nations: Bargaining, Decision Making, and System Structure in International Crises. New Jersey: Princeton University Press.

Sood, V.K. and Sawhney, P. (2003). Operation Parakram: The War Unfinished. New Delhi: Sage Publications.

Sood, V.K. and Sawhney, P. (2003). Operation Parakram: The War Unfinished. New Delhi: Sage Publications.

Soviet Review (New Delhi). 18 September 1965, 8-10 comp. by Rajendra Kumar Jain. (1979). Soviet South Asian Relations 1947-1978. TASS Statement. UK: Martin Robertson \& Company Ltd. UK: Martin Robertson \& Company Ltd., pp. 76-78.

Soviet Review. 12 October 197134 comp. by Rajendra Kumar Jain Soviet-South Asian Relations 1947-1978 Volume 1, Document 49 (Extract) Kosygin's Speech at a Luncheon Given in Honour of Indian Prime Minister Indira Gandhi. 28 September 1971, UK: Martin Robertson \& Company Ltd p. 122.

Soviet Review. 18 January 1972 Supplement, 12-3 comp. by Rajendra Kumar Jain Soviet-South Asian Relations 1947-1978 Volume 1 Document 56 TASS Statement. 5 December 1971, UK: Martin Robertson \& Company Ltd. p. 133.

Soviet Review. 18 January 1972 Supplement, 8-9 comp. by Rajendra Kumar Jain Soviet-South Asian Relations 1947-1978 Volume 1. Soviet President Podgorny's Message to President Yahya Khan of Pakistan. 2 April 1971. UK: Martin Robertson \& Company Ltd., p. 105. 
Soviet Review. 22 January 1966 7-8 comp. by Rajendra Kumar Jain. (1979) SovietSouth Asian Relations 1947-1978. UK: Martin Robertson \& Company Ltd., pp. 98-99.

Spiegel Online (2002). Der Spiegel with Pervez Musharraf. Pakistans Musharraf droht Indien mit der Atombombe. 05.04.2002 [online] Available at: http://www.spiegel.de/politik/ausland/kaschmir-konflikt-pakistans-musharraf-droht-indienmit-der-atombombe-a-190389.html [Accessed 23.03.2017].

Stratfor (2016). Russia Re-Evaluates Security Ties in Central Asia. 3 March 2016 [online] Available at: https://www.stratfor.com/analysis/russia-re-evaluates-security-tiescentral-asia [Accessed 26.03.2017].

Subramanian, T.S. (2002). Missile Maneuvers. Frontline, Cover Story, Volume 19, Issue 2, 8-21 June 2002 [online] Available at: http://www.frontline.in/static/html/fl1912/19120200.htm [Accessed 24.03.2017].

Sudarshan, V. (2002). Mirage 2001-02. Outlook, 04 November 2002 [online] Available at: http://www.outlookindia.com/magazine/story/mirage-2001-02/217748 [Accessed 28.03.2017].

Sundarji, K. (1995). Proliferation of WMD and the Security Dimensions in South Asia: An Indian View in William H. Lewis and Stuart E. Johnson (eds.) Weapons of Mass Destruction: New Perspectives on Counterproliferation, Washington D.C.: National Defense University Press, pp. 55-70.

Sutter, R.G. and Cronin, R.P. China-India Border Friction CRS Report, 87-514F, Washington, DC, Congressional Research Service, Library of Congress. 19 June 1987, cited in Surjit Mansingh and Steven Levin (1989) "China and India: Moving beyond Confrontation". Problems of Communism, Vol. 38, No. 2-3, Mar-June 1989, pp. 41-42.

Sweeney, J., Holsoe, J. and Vulliamy, E. (1999). NATO bombed Chinese deliberately. The Guardian, Kosovo: Special Report. 17 October 1999 [online] Available at: https://www.theguardian.com/world/1999/oct/17/balkans [Accessed 29.03.2017].

Sydney Morning Herald (Australia) (1987). Pakistan and India to Try Cricket Diplomacy. 31 January 1987, Saturday Late Edition, Source: Reuter Section: News and Features: pg. 20, NEXIS.

Talbott, S. (2004). Engaging India: Diplomacy, Democracy, and the Bomb. Washington DC.: Brookings Institution Press.

Tannenwald, N. (1999). The Nuclear Taboo: The United States and Normative Basis of Nuclear Non-Use. International Organization, Vol. 53, No.3, Summer 1999, pp. 433-468.

Tarnowski, A. (1987). Reuters Ltd. 22 February 1987, in Bajpai K.P. et al. (1997). 
Brasstacks and Beyond: Perception and Management of Crisis in South Asia. New Delhi: Ajay Kumar Jain Manohar Publishers \& Distributers, p. 175.

Tashkent Declaration, n.33, 4-6. The Tashkent Declaration 10 January 1966 comp. by Rajendra Kumar Jain. (1979). Soviet South Asian Relations 1947-1978. UK: Martin Robertson \& Company Ltd., pp. 95-98.

Taubman, P. (1984). Worsening India-Pakistan Ties Worry U.S. The New York Times, 15 September 1984 [online] Available at:

http://www.nytimes.com/1984/09/15/world/worsening-india-pakistan-ties-worry-us.html [Accessed 27.03.2017].

Tellis, A.J., Fair, C.C., Medby, J.J. (2001). Limited Conflicts under the Nuclear Umbrella: Indian and Pakistani Lessons from the Kargil Crisis. CA: RAND Corp Santa Monica.

Tellis, J.A. (2002). The Strategic Implications of a Nuclear India. Orbis, Volume 46, Issue 1, Winter 2002, pp. 13-45.

The American Papers Secret and Confidential India-Pakistan-Bangladesh Documents 1965-1973. Telegram from the US Embassy in Pakistan to the US Department of State. 30 April 1965 10.45, comp. by Roedad Khan Oxford: Oxford University Press, 1999, pp. 3-5.

The American Papers Secret and Confidential India-Pakistan-Bangladesh Documents 1965-1973. Telegram from the US Department of State to the US Embassy in Pakistan. 6 September 1965, in comp. by Roedad Khan, Oxford: Oxford University Press, 1999, pp. 28-29.

The American Presidency Project Press Briefing by Deputy Press Secretary Gordon Johndroe. 31 December 2008 [online] Available at: http://www.presidency.ucsb.edu/ws/index.php?pid=85279 [Accessed 28.03.2017].

The American Presidency Project William J. Clinton Joint Statement With Prime Minister Nawaz Sharif on Pakistan on the Situation in Kashmir [online] Available at: http://www.presidency.ucsb.edu/ws/?pid=57835 [Accessed 31.03.2017].

The Economist (2016). Our bulldozers, our rules: China's foreign policy could reshape a good part of the world economy The Economist. 2 July 2016 [online] Available at: http://www.economist.com/news/china/21701505-chinas-foreign-policy-could-reshape-goodpart-world-economy-our-bulldozers-our-rules [Accessed 29.03.2017].

The Hindu (1999). Resume Talks, China Tells Sharif. 29 June 1999, cited in Tellis, A.J., Fair, C.C., Medby, J.J. (2001). Limited Conflicts under the Nuclear Umbrella: Indian 
and Pakistani Lessons from the Kargil Crisis. CA: RAND Corp Santa Monica, p. 21.

The Hindu (1999). Russia Rejects Pakistan Version of Kargil Crisis. 2 July 1999, in Peter R. Lavoy (edt.) Asymetric Warfare in South Asia: The Causes and Consequences of the Kargil Conflict. New York: Cambridge University Press, 2009, p. 199.

The Hindustan Times (1987). Army Takes Up Positions along Punjab Border: Pak Warned Against Confrontation. 24 January 1987, cited Bajpai K.P. et al. (1997). Brasstacks and Beyond: Perception and Management of Crisis in South Asia. New Delhi: Ajay Kumar Jain Manohar Publishers \& Distributers, p. 167.

The Hindustan Times, 22 March 1965 cited in McGarr, P.M. (2013). Britain, the United States and the Indian Subcontinent 1945-1965. New York: Cambridge University Press, p. 303.

The Independent (2009). Diplomat Denies Pakistan Role in Mumbai Attacks. 31 January 2009 [online] Available at: http://www.independent.co.uk/news/world/asia/diplomatdenies-pakistan-role-in-mumbai-attacks-1521700.html [Accessed 28.03.2017].

The Nation (Lahore), 2 March 1987 cited in Chari, P.R. (1995). Indo-Pak Nuclear Standoff: The Role of the United States. New Delhi: Ajay Kumar Jain Manohar Publishers \& Distributers., p. 131.

The Observer (London), 1 March 1987, cited in Chari, P.R. (1995). Indo - Pak Nuclear Standoff: The Role of the United States. New Delhi: Ajay Kumar Jain Manohar Publishers \& Distributers, p. 130.

The Pioneer (1999). Kashmir Is Not Kosovo. 30 May 1999, cited in Tellis, A.J., Fair, C.C., Medby, J.J. (2001). Limited Conflicts under the Nuclear Umbrella: Indian and Pakistani Lessons from the Kargil Crisis. CA: RAND Corp Santa Monica, p. 21.

The Pioneer (1999). Show Restraint: China. 28 May 1999, cited in Tellis, A.J., Fair, C.C., Medby, J.J. (2001). Limited Conflicts under the Nuclear Umbrella: Indian and Pakistani Lessons from the Kargil Crisis. CA: RAND Corp Santa Monica, p. 21.

Thornton, T. and Bratersky, M. (1995). India and Pakistan: The Roots of the Conflict in I. William Zartman and Victor A. Kremenyuk (eds.) Cooperative Security: Reducing Third World Wars Syracuse: Syracuse University Press, pp. 179-203.

Times of India (1986). Many Express, Main Trains Cancelled. 10 November 1986 cited in Bajpai K.P. et al. (1997). Brasstacks and Beyond: Perception and Management of Crisis in South Asia New Delhi: Ajay Kumar Jain Manohar Publishers \& Distributers, p. 160.

Times of India (1987). 2 February 1987 in Bajpai K.P. et al. (1997). Brasstacks and Beyond: Perception and Management of Crisis in South Asia New Delhi: Ajay Kumar Jain 
Manohar Publishers \& Distributers, p. 172.

Times of India (1990). Crush Pak Camps: BJP 8 April 1990 cited in Chari, P. R. et al. (2003). Perception, Politics, and Security in South Asia: The compound crisis of 1990. London and New York: RoutledgeCurzon, Taylor and Francis Group, p. 75.

Times of India (2002). Premature Pullback vs Army Fatigue. 26 October 2002 [online] Available at: http://timesofindia.indiatimes.com/edit-page/TIMES-SAMVADBRPrematurePullback-vs-Army-Fatigue/articleshow/26300607.cms [Accessed 21.03.2017].

Times of India (2008). US Support Mumbai attack investigation: Bush tells PM. 1 December 2008 [online] Available at: http://timesofindia.indiatimes.com/world/us/US-tosupport-Mumbai-attack-investigation-Bush-tells-PM-/articleshow/3777459.cms?referral=PM [Accessed 28.03.2017].

Times of India Press Trust of India (PTI) (2008). Mumbai Attack: Rice asks Pak to act urgently, else US will act. 6 December 2008 [online] Available at: http://timesofindia.indiatimes.com/world/pakistan/Mumbai-attack-Rice-asks-Pak-to-acturgently-else-US-will-act/articleshow/3801376.cms? [Accessed 21.03.2017].

Times of India. (1986). Junejo for Talks With India at All Levels. 3 December 1986, cited in Bajpai K.P. et al. (1997). Brasstacks and Beyond Brasstacks: Perception and Management of Crisis in South Asia New Delhi: Ajay Kumar Jain Manohar Publishers \& Distributers, p. 164.

Torode, G. and Collett-White, M. (2016). Ahead of key court ruling, Beijing in propaganda overdrive Reuters. 3 July 2016 [online] Available at: http://www.reuters.com/article/us-southchinasea-ruling-idUSKCNOZJ117 [Accessed 24.03.2017].

Touval, S. and Zartman, I. W. (1989). Mediation in International Conflicts in Kenneth Kressel and Dean G. Pruitt (eds.) Mediation Research: The Process and Effectiveness of Third-Party Intervention San Francisco: Jossey-Bass, pp. 115-137.

Trivedi, R. (2008). India's Relations with Her Neighbours. India: ISHA Books.

UN Document A/PV2003 comp. Rajendra Kumar Jain Soviet-South Asian Relations 1947-1978 Volume 1 Statement by the Soviet Representative Malik in the UN General Assembly. 7 December 1971, (Extracts) Document 62, the UK: Martin Robertson \& Company Ltd., pp. 145-149.

UN Document S/6671, TASS Statement. 7 September 1965, [online] Available at: http:/www.un.org/en/ga/search/view_doc.asp?symbol=S/6671 [Accessed 22.03.2017].

UN Document S/6685, Message from Mr. Kosygin Addressed to Prime Minister 
Shastri of India, 4 September 1965, pp. 2-3 [online] Available at: http://www.un.org/en/ga/search/view_doc.asp?symbol=S/6685 [Accessed 24.03.2017].

UN Document S/PV 1237, 35-7 comp. Rajendra Kumar Jain. (1979) Soviet South Asian Relations 1947-1978. UK: Martin Robertson \& Company Ltd., p. 68-70.

UN Document S/PV 1241, 25-8. comp. Rajendra Kumar Jain. (1979). Soviet South Asian Relations 1947-1978. UK: Martin Robertson \& Company Ltd., p. 80-81.

UN Document S/PV 1607 comp. Rajendra Kumar Jain (1981) China - South Asian Relations 1947-1980. Document 199. The Great Britain: The Harvester Press, John Spiers, p. 223.

UN Document S/PV 1608, 5-6 comp. Rajendra Kumar Jain Soviet-South Asian Relations 1947-1978. Volume 1 Statement by the Soviet Representative Malik in the Security Council. 6 December 1971, (Extracts). UK: Martin Robertson \& Company Ltd., p. 141.

UN Document S/PV 1613 comp. Rajendra Kumar Jain Soviet-South Asian Relations 1947-1978. Volume 1 Document. 64. UK: Martin Robertson \& Company Ltd., pp. 149-155.

UN Document S/PV 1615 comp. by Rajendra Kumar Jain (1981) China - South Asian Relations 1947-1980. Document 203. The Great Britain: The Harvester Press, John Spiers, pp. 230-232.

UN Document S/PV 1615 comp. Rajendra Kumar Jain Soviet-South Asian Relations 1947-1978. Volume 1 Document 65. UK: Martin Robertson \& Company Ltd., pp. 155-158.

UN Document S/PV 1621 comp. Rajendra Kumar Jain Soviet-South Asian Relations 1947-1978. Volume 1 Statement by the Soviet Representative Malik in the Security Council, 21 December 1971 Document 70. UK: Martin Robertson \& Company Ltd., pp. 162-166.

UN Document S/PV, 3046, The Address of the President and Chairman of the Government of the Russian Federation Boris Yeltsin to the United Nations, 31 January 1992, p. 44 [online] Available at:

http://www.un.org/en/ga/search/view_doc.asp?symbol=S/PV.\%203046 [Accessed 23.01.2018].

UN Resolution 211 (1968). 20 September 1965, pp. 14-15. [online] Available at: http://www.un.org/en/ga/search/view_doc.asp?symbol=S/RES/211(1965) [Accessed 22.03.2017].

UN Resolution 38 (1948). Resolution of 17 January 1948 [S/651]. Resolutions Adopted and Decisions Taken By the Security Council in 1948 [online] http://unscr.com/en/resolutions/doc/38 Available at: [Accessed 31.03.2017].

UN Resolution 39 (1948). Resolution of 20 January 1948 [S/654]. Resolutions 
Adopted and Decisions Taken By the Security Council in 1948 [online] Available at: http://unscr.com/en/resolutions/doc/39 [Accessed 31.03.2017].

UN Resolution 47 (1948). Resolution of 21 April 1948 [S/726]. Resolutions Adopted and Decisions Taken by the Security Council in 1948 [online] Available at: http://unscr.com/en/resolutions/doc/47 [Accessed 31.03.2017].

UN Security Council (1999). Security Council Rejects Demand for Cessation of Use of Force Against Federal Republic of Yugoslavia, Press Release SC/6659 26 March 1999 [online] Available at: http://www.un.org/press/en/1999/19990326.sc6659.html [Accessed 31.03.2017].

UNCHR The UN Refugee Agency: The State of The World's Refugees 2000: Fifty Years of Humanitarian Action. Chapter 3 Rupture in South Asia [online] Available at: http://www.unhcr.org/3ebf9bab0.html pp. 60-61 [Accessed 27.03.2017].

United Kingdom National Archives, CRO Circular, No.118 The Dispute Between India and Pakistan over the Rann of Kutch, 28 April 1965, PREM 13/391, TNA, Kew, London (hereafter TNA), cited in McGarr, P.M. (2013). The Cold War in South Asia: Britain, the United States and the Indian Subcontinent, 1945-1965. New York: Cambridge University Press, p. 302.

United Kingdom National Archives. Sykes to Bottomley, Pakistan: The Rann of Kutch Dispute. 16 July 1965, PREM 13/393, TNA, cited in McGarr, P.M. (2013). The Cold War in South Asia: Britain, the United States and the Indian Subcontinent 1945-1965. The US: Cambridge University Press, p. 301.

United Nations Convention on the Law of the Sea [online] Available at: http://www.un.org/depts/los/convention_agreements/texts/unclos/unclos_e.pdf [Accessed 20.03.2017].

United Nations Peace Maker (1993). Agreement on the Maintenance of Peace and Tranquility along the Line of Actual Control in the India-China Border Areas. 7 September 1993 [online] Available at: http://peacemaker.un.org/chinaindia-borderagreement93 [Accessed 19.03.2017].

United Nations Security Council (1999) SC/6674/REV. 1 China, At Security Council Meeting, Registers Strongest Possible Protest Over Attack Against its Embassy in Belgrade Press Release. 8 May 1999 [online] Available at:

http://www.un.org/press/en/1999/19990508.SC6674.R1.html [Accessed 29.03.2017].

United Press International (1987). India to Pull Troops Back From Pakistani Border. 5 February 1987 [online] Available at: http://www.upi.com/Archives/1987/02/05/India-to- 
pull-troops-back-from-Pakistani-border/5091539499600/ [Accessed 27.03.2017].

United Press International (1987). India, Pakistan Begin Talks on Border Tensions. 30 January 1987 [online] Available at: http://www.upi.com/Archives/1987/01/30/India-Pakistanbegin-talks-on-border-tensions/6509368812046/ [Accessed 27.03.2017].

United Press International (1987). Shooting Incidents Reported. 28 January 1987 [online] Available at: http:/www.upi.com/Archives/1987/01/28/Shooting-incidentsreported/9357538808400/ [Accessed 27.03.2017].

United States Information Service (USIS) Press Release. 6 April 1971, comp. by Rajendra Kumar Jain US-South Asian Relations 1947-1982. Statement by the Spokesman of the Department of State, Volume 3, p.3, Document 1, p. 3.

US Department of State Bulletin The Evolution of Foreign Policy Address by Secretary Dulles Vol. XXX, No. 761 Publication 5349. 25 January 1954, pp. 107-110. cited in Freedman, L. (1981/1989). The Evolution of Nuclear Strategy. The International Institute for Strategic Studies, London: The Macmillan Press Ltd., Printed in The People's Republic of China, p. 85.

US House of Representative Hearing on Global Terrorism: South Asia - The New Locus. 12 July 2000, Testimony held by Representatives David E. Bonior, p. 6. [online] Available at: http://www.gpo.gov/fdsys/pkg/CHRG-106hhrg68482/pdf/CHRG-106hhrg68482.pdf [Accessed 28.03.2017].

US House of Representatives Congressional Record. India and Pakistan's Recent Nuclear Detonations testimony by Robert Underwood. 3 June 1998, H54 [online] Available at: http://www.gpo.gov/fdsys/pkg/CREC-1998-06-03/pdf/CREC-1998-06-03-pt1PgH4030.pdf [Accessed 28.03.2017].

US House of Representatives Hearing Before the Committee on International Relations. 20 October 1999, testimony held by Ms. Teresita Schaffer, p. 33 [online] Available at: $\quad$ http://www.gpo.gov/fdsys/pkg/CHRG-106hhrg61551/pdf/CHRG-106hhrg61551.pdf [Accessed 28.03.2017].

US Senate Congressional Record India and Pakistan Testimony given by Senator Bob Kerrey. 24 June 1999, S7679 [online] Available at: http://www.gpo.gov/fdsys/pkg/CREC-1999-06-24/pdf/CREC-1999-06-24-pt1-PgS7679-3.pdf [Accessed 29.03.2017].

US Senate Hearing Before the Committee on Armed Services S. HRG. 107-765. 19 March 2002, p. 5 [online] Available at: http://www.gpo.gov/fdsys/pkg/CHRG107shrg82913/pdf/CHRG-107shrg82913.pdf [Accessed 28.03.2017]. 
US Senate Hearing Before the Committee on Foreign Relations: What is Next in the War on Terrorism? S. HRG. 107-417, 7 February 2002, p. 10. [online] Available at: http://www.gpo.gov/fdsys/pkg/CHRG-107shrg78906/pdf/CHRG-107shrg78906.pdf [Accessed 28.03.2017].

Van Creveld, M. (1993). Nuclear Proliferation and the Future of Conflict. New York: Free Press.

Varadarajan, S. and Dikshit, S. (2009). No Dilution of Position, says Pranab The Hindu. 17 January 2009 [online] Available at: http://www.thehindu.com/todays-paper/Nodilution-of-position-says-Pranab/article16352902.ece [Accessed 14.03.2017].

Viswam, S. and Salamat A. (1990). Vale of Tears. Far Eastern Economic Review, 8 February 1990, pp. $19-21$.

Voice of America (VOA). India Plans No Military Action Against Pakistan Over Mumbai Attacks. 27 October 2009 [online] Available at: http://www.voanews.com/a/a-132008-12-18-voa39-66737352/561773.html [Accessed 21.03.2017].

Vremya Novostei [Newstime] - Moscow (2002). Katerina Labetskaya, „Mentalitet 'Kholodnoy Voiny' Obyazan Umeret „, [The ,, cold war „, mentality has to die], interview with Deputy Foreign Minister Vyacheslav Trubnikov. 11 September 2002, p. 4. cited in Martin Malek (2004). Russian Policy toward South Asia: An Update Asian Survey, Vol. 44, No.3, May/June 2004, University of California Press, pp. 384-400.

Waltz, K.N. (1981). The Spread of Nuclear Weapons: More May Be Better. The Adelphi Papers, Vol. 21, No.171, London: International Institute for Strategic Studies.

Waltz, K.N. (1990). Nuclear Myths and Political Realities. The American Political Science Review, Vol. 84, No.3, September 1990, pp. 731-745.

Washington Post, 16 September 1965 cited in Brines, R. (1968). The Indo-Pakistani Conflict. London: Pall Mall Press Ltd., pp. 365.

Washington Post, 5 January 1972 comp. Washington Special Action Group Meeting on India/Pakistan. 3 December 1971, comp. by Rajendra Kumar Jain US - South Asian Relations 1947-1982. Vol. 3, p. 25.

Washington Special Action Group Meeting, 8 December 1971 comp. by Rajendra Kumar Jain US - South Asian Relations 1947-1982 Vol. 3, p. 44.

Wax, E. and Lakshmi, R. (2008). As Rice Presses Pakistan, Mumbai Residents Hold Massive Rally Washington Post Foreign Service Thursday, 4 December 2008 [online] Available at: http://www.washingtonpost.com/wp- 
dyn/content/article/2008/12/02/AR2008120200884.html?sid=ST2008120203535

[Accessed 13.03.2017].

Weede, E. (1983). Extended Deterrence by Superpower Alliance. The Journal of Conflict Resolution, Vol. 27, No.2, June 1983, pp. 231-254.

Weiner, T. (1995). U.S. Suspects India Prepares To Conduct Nuclear Tests. The New York Times, 15 December 1995 [online] Available at:

http://www.nytimes.com/1995/12/15/world/us-suspects-india-prepares-to-conduct-nucleartest.html [Accessed 27/03/2017].

Weintraub, R. M. (1987). Washington Post Foreign Service. 24 March 1987, cited in Bajpai K.P. et al. (1997). Brasstacks and Beyond: Perception and Management of Crisis in South Asia New Delhi: Ajay Kumar Jain Manohar Publishers \& Distributers, p. 180.

Weisman, S.R. (1987). India - Pakistan Troop Tensions Ease. The New York Times, 5 February 1987 [online] Available at: http://www.nytimes.com/1987/02/05/world/indiapakistan-troop-tensions-ease.html [Accessed 27.03.2017].

Weisman, S.R. (1987). India and Pakistan Avoid Declaring War or Peace. The New York Times, 29 March 1987 [online] Available at:

http://www.nytimes.com/1987/03/29/weekinreview/india-and-paskistan-avoid-declaring-waror-peace.html [Accessed 28.03.2017].

Weisman, S.R. (1987). Pakistan's Nuclear Aims Worrying U.S. The New York Times, 20 February 1987 [online] Available at: http://www.nytimes.com/1987/02/20/world/pakistans-nuclear-aims-worrying-us.html [Accessed 27.03.2017].

Weissman, S. and Krosney, H. (1981). The Islamic Bomb: The Nuclear Threat to Israel and the Middle East. New York: Times Books.

Wendt, A. (1992). Anarchy is What States Make of It: The Social Construction of Power Politics. International Organization, Vol. 46, No. 2, Spring 1992, pp. 391-425.

Werner, S., and Yuen, A. (2005). Making and Keeping Peace. International Organization, Vol. 59, No.2, Spring, 2005, pp. 261-92.

White House Office of the Press Secretary President George W. Bush Joint Statement Between President George W. Bush and Prime Minister Manmohan Singh. 18 July 2005 [online] Available at: http://georgewbushwhitehouse.archives.gov/news/releases/2005/07/20050718-6.html [Accessed 28.03.2017].

White House Presidential News and Speeches President George W. Bush President to Send Secretary Rumsfeld to South Asia: Remarks by the President at Conclusion of Cabinet Meeting The Cabinet Room. 30 May 2002 [online] Availabe at: https://georgewbush- 
whitehouse.archives.gov/news/releases/2002/05/20020530-1.html [Accessed 24.03.2017].

Wilson Center Digital Archive International History Declassified (hereafter Wilson Center) Memorandum of Conversation: Deputy Foreign Minister Geng Biao and Director Zhang Wenji with Indian Ambassador to China Parthasarathy. 19 July 1961 [online] Available at:

http://digitalarchive.wilsoncenter.org/document/121757.pdf?v=dd981a0e361c5df5bf6326eb0e 951db7 [Accessed 27.03.2017].

Wilson Center. Abstract of Conversation between Chinese Premier Zhou Enlai and Pakistani Ambassador to China Sultanuddin Ahmad. 04 January 1956 [online] Available at: http://digitalarchive.wilsoncenter.org/document/114840.pdf? $\mathrm{v}=\mathrm{bb} 8424 \mathrm{ddee} 551 \mathrm{a} 7 \mathrm{~d} 7 \mathrm{de} 3 \mathrm{ca} 1 \mathrm{~d} 9$ 766604a [Accessed 27.03.2017].

Wilson Center. Bureau of Intelligence and Research, US Department of State, 'IndiaPakistani Views on a Nuclear Weapons Option and Potential Repercussions' History and Public Policy Program Digital Archive, Department of State FOIA release, copy courtesy of Jeffrey Richelsen. Obtained and Contributed by William Burr and included in NPIHP Research Update. 25 June 1981, p. 6. [online] Available at: http://digitalarchive.wilsoncenter.org/document/114242 [Accessed 27.03.2017].

Wilson Center. Draft State Department Telgram to US Embassy Beijing, ' Possible Indian Nuclear Test' History and Public Policy Program Digital Archive, Mandatory Declassification Review request. Obtained and contributed by William Burr and included in NPIHP Research Update number 10. 15 December 1995 [online] Available at: http://digitalarchive.wilsoncenter.org/document/116342 [Accessed 27.03.2017].

Wilson Center. Letter from Homi Bhabba to Sir Dorab of Tata Trust History and Public Program Digital Archive, Institute for Defense Studies and Analyses (IDSA), Tata Institute of Fundamental Research, Homi Bhaba Papers, IDHA-HBP-12031944. Obtained and contributed by A. Vinod Kumar and the Institute for Defence Studies and Analyses. 12 March 1944 [online] Available at: http://digitalarchive.wilsoncenter.org/document/114188.pdf?v=daacab5241a927c6df8822363 469984b [Accessed 27.03.2017].

Wilson Center. Premier Zhou Enlai Receives Pakistani Ambassador Ahmed, and Accepts Letter From Pakistani Premier Suhrawady Explaining the Kashmir Issue 16 Obtained by Sulman Khan and translated by Anna Beth Keim. 16 February 1957 [online] Available at:

http://digitalarchive.wilsoncenter.org/document/112749.pdf?v=22846ee5f9688ac2893645c16 
87e22f2 [Accessed 27.03 2017].

Wilson Center. Special Assistant for NPI, NFAC, CIA, to Resource Management Staff, Office of Program Assessment et al, 'Request for Review of Draft Paper on the Security Dimension of Non-Proliferation` 09 April 1981, History and Public Policy Program Digital Archive, Mandatory Declassification Review Request. Obtained and contributed by William Burr and included in NPIHP Research Update Number 6, p. 19 [online] Available at: http://digitalarchive.wilsoncenter.org/document/114233 [Accessed 27.03.2017].

Wilson Center. Summary of Conversation between Premier Zhou Enlai and Pakistan`s Ambassador to the PRC, Rashidi (Excerpt). 08 March 1962 [online] Available at: http://digitalarchive.wilsoncenter.org/document/121570.pdf?v=770f07ac805899ceceb28538d 937210c [Accessed 27.03.2017].

Wilson Center. US Department of State Cable 145139 to US Embassy India [Repeating Cable Sent to Embassy Pakistan], ' Non-Proliferation in South [Asia]' 06 June 1979, p. 6 [online] Available at:

http://digitalarchive.wilsoncenter.org/document/114198.pdf? $\mathrm{v}=50 \mathrm{~d} 4 \mathrm{fa} 5 \mathrm{adf1b} 76 \mathrm{ec} 1 \mathrm{f393398bc}$ 70a7c5 [Accessed 27/03/2017].

Wilson, W. (2008). The Myth of Nuclear Deterrence. Nonproliferation Review, Vol. 15, No. 3, November 2008, pp. 421-439.

Wirsing, R.G. (2003). Kashmir in the Shadow of War: Regional Rivalries in a Nuclear Age. New York: M.E. Sharpe Inc.

Wischnick, E. (2002). Growing U.S. Security Interests in Central Asia. Strategic Studies Institute Report p. 1 [online] Available at: http://www.strategicstudiesinstitute.army.mil/pubs/display.cfm?pubID=110 [Accessed 29.03.2017].

Wishnick, E. (2009). Russia, China, and The United States in Central Asia: Prospects for Great Power Competition and Cooperation in the Shadow of the Georgian Crisis. Strategic Studies Institute Report, pp. 2-3. [online] Available at:

http://www.strategicstudiesinstitute.army.mil/pdffiles/PUB907.pdf [Accessed 26.03.2017].

Wohlstetter, A. (1959). The Delicate Balance of Terror. Foreign Affairs, Vol. 37, No. 2 , January 1959.

Xinhua General News Service (1990). Chinese Foreign Minister meets Pakistan's Special Envoy. 16 February 1990, Friday, NEXIS.

Xinhua General News Service (1990). Pakistan Prime Minister meets Chinese Defense Minister. 20 February 1990, Tuesday, NEXIS. 
Xinhua General News Service Indian Prime Minister on His Country's Nuclear Policy Xinhua General News Service. 21 February 1990 Wednesday, NEXIS.

Xinhua News Agency (1999). China Says It Hopes for Political Solution to Kashmir Issue. 11 June 1999, NEXIS.

Xinhua News Agency (1999). Today's Diplomatic News Highlights, 11 June 1999, NEXIS.

Xinhua News Agency (2002). Jiang Hopes For Peaceful Settlement of India - Pakistan Dispute Xinhua General News Service. 2 August 2002, NEXIS.

Xinhua News Agency. (2002). China Urges India-Pakistan talks on border tensions. 31 July 2002, NEXIS.

Xinhua News Agency; 4 May 1965 comp. Rajendra Kumar Jain (1981) China - South Asian Relations 1947-1980. The Great Britain: The Harvester Press, John Spiers, p. 63.

Yang, Lu (2017). China - India Relations in the Contemporary World: Dynamics of National Interest and Identity, New York: Routledge, pp. 21-22.

Young, O.R. (1967). The Intermediaries: Third Parties in International Crises. Princeton, New Jersey: Princeton University Press.

Zartman, I.W. (1985/1989). Ripe for Resolution: Conflict and Intervention in Africa. New York: Oxford University Press.

Zartman, I.W. (2008). The Timing of Peace Initiatives: hurting stalemates and ripe moments in Darby, J. and MacGinty, R. (eds.) Contemporary Peacemaking: Conflict, Peace Processes and Post-War Reconstruction. New York: Palgrave MacMillan, pp. 22-36.

Zartman, W.I. and Touval, S. (1996). International Mediation in the Post-Cold War Era in Chester A. Crocker, Fen Osler Hampson, Pamela R. Aall (eds.) Managing Global Chaos: Sources of and Responses to International Conflict. Washington, D.C.: United States Institute of Peace Press, pp. 445-461. 